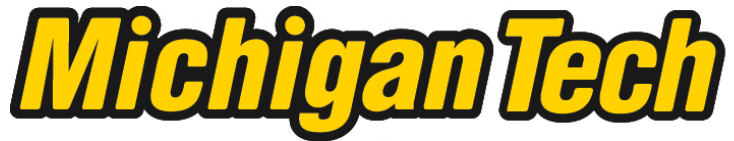 \\ Michigan Technological University Create the Future Digital Commons @ Michigan Tech
}

Evaluation of sugar maple dieback in the Upper Great Lakes region and development of a forest health youth education program

Tara L. Bal

Michigan Technological University

Follow this and additional works at: https://digitalcommons.mtu.edu/etds

Part of the Education Commons, Forest Sciences Commons, and the Plant Pathology Commons Copyright 2013 Tara L. Bal

\section{Recommended Citation}

Bal, Tara L., "Evaluation of sugar maple dieback in the Upper Great Lakes region and development of a forest health youth education program", Dissertation, Michigan Technological University, 2013.

https://doi.org/10.37099/mtu.dc.etds/642

Follow this and additional works at: https://digitalcommons.mtu.edu/etds

Part of the Education Commons, Forest Sciences Commons, and the Plant Pathology Commons 


\title{
EVALUATION OF SUGAR MAPLE DIEBACK IN THE UPPER GREAT LAKES REGION AND DEVELOPMENT OF A FOREST HEALTH YOUTH EDUCATION PROGRAM
}

\author{
By \\ Tara L. Bal \\ A DISSERTATION \\ Submitted in partial fulfillment of the requirements for the degree of \\ DOCTOR OF PHILOSOPHY \\ In Forest Science
}

MICHIGAN TECHNOLOGICAL UNIVERSITY

2013

(C) 2013 Tara L. Bal 
This dissertation has been approved in partial fulfillment of the requirements for the Degree of DOCTOR OF PHILOSOPHY in Forest Science.

School of Forest Resources and Environmental Science

Dissertation Advisor: $\quad$ Dr. Andrew J. Storer

Committee Member: $\quad$ Dr. Martin F. Jurgensen

Committee Member: $\quad$ Dr. Dana L. Richter

Committee Member: $\quad$ Dr. Bradley H. Baltensperger

School Dean: Dr. Terry L. Sharik 


\section{Table of Contents}

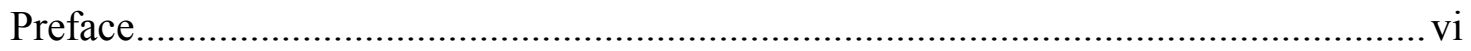

Acknowledgements .......................................................................................... vii

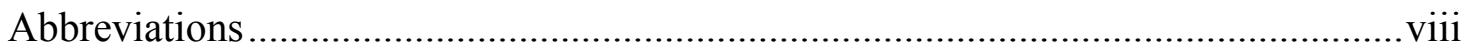

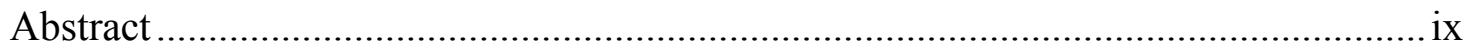

\section{Chapter 1. Introduction}

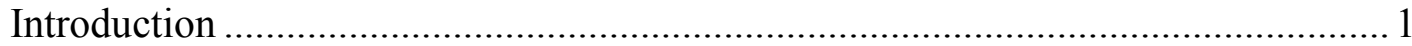

1.1. History of sugar maple dieback in the Upper Peninsula, MI ............................. 2

1.2. Factors associated with sugar maple dieback in the eastern range...................... 3

1.3. Implications of the research presented here .................................................. 4

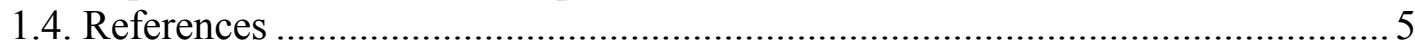

\section{Chapter 2. Sugar Maple Dieback Trends in the Western Upper Great}

\section{Lakes Region}

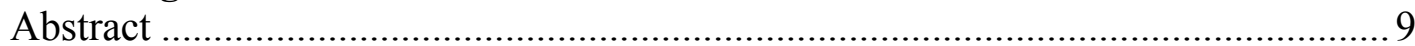

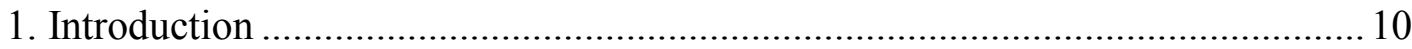

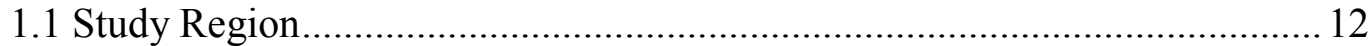

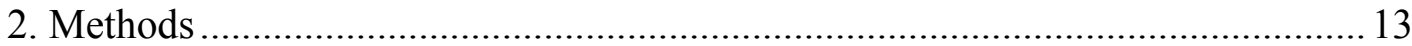

2.1. Plot Establishment and Base Measurements

2.2. Tree Cores

2.3. Climate Data

2.4. Statistical Procedures

3. Results 16

3.1. Dieback Occurrence

3.2. Relationship between Dieback and Growth

3.3. Relationship between Climate, Location, and Growth

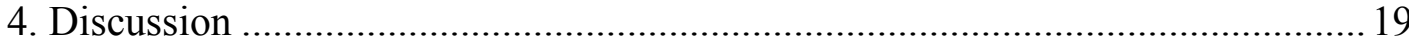

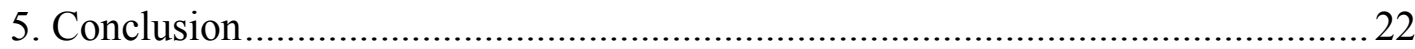

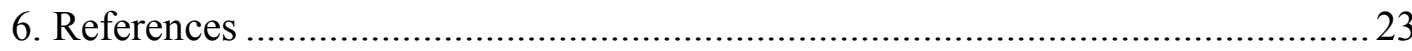

\section{Chapter 3. Importance of Forest Floor Perturbation resulting from}

Exotic Earthworm Activity for Sugar Maple Dieback in the Western Upper Great Lakes Region

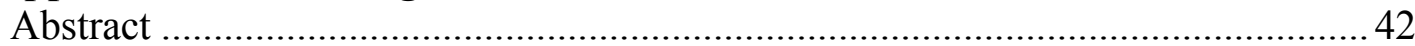

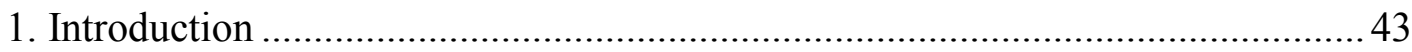

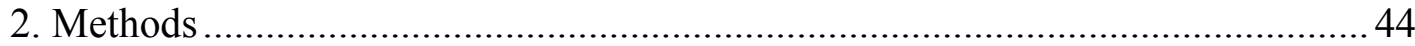

2.1 Plot Establishment and Base Measurements

2.2 Tree Cores

2.3 Soil Sampling 
2.4 Statistical Procedures

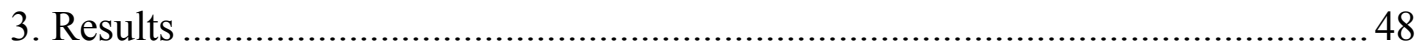

3.1. Plot Characteristics and Dieback

3.2. Plot Characteristics and Regeneration

3.3. Plot Characteristics and Growth

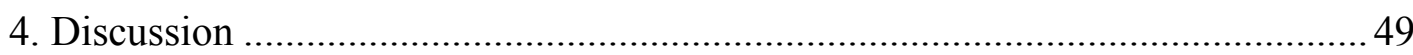

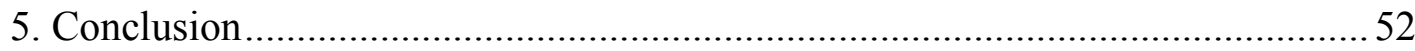

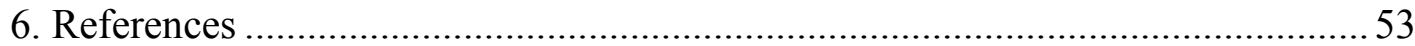

\section{Chapter 4. Sugar Maple Health and Relationships with Foliar and}

Soil Nutritional Status in the Western Upper Great Lakes

\section{Region}

Abstract 68

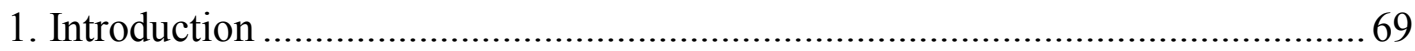

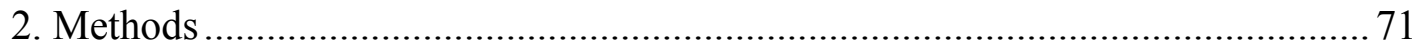

2.1 Plot Establishment

2.2 Foliage Sampling

2.3 Tree Core Sampling

2.4. Soil Sampling

2.5 Statistical Procedures

3. Results

3.1. Foliar Characteristics, Nutrition, and Dieback

3.2. Foliar Nutrition and Growth

3.3. Foliar Retranslocation

3.4 Effects of Soil Characteristics

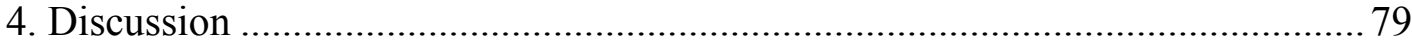

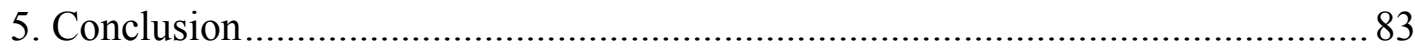

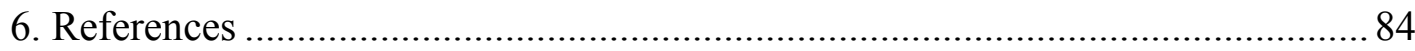

\section{Chapter 5. The Relationship of the Sapstreak Fungus, Ceratocystis virescens,} with Sugar Maple Dieback and Decay in Northern Michigan

Preface.

Abstract .....

1. Introduction

1.1. Sapstreak Characteristics and Biology

1.2. Sapstreak and Wood Decay

1.3. Objectives

2. Materials and Methods.

2.1. Field Sampling for the Sapstreak Fungus

2.2. Soil Block Decay Test

3. Results

3.1 Incidence of Sapstreak in Maple Stands

3.2 Incidence of Sapstreak in a recently logged stand

3.3 Soil Block Decay Test

4. Discussion 
5. References.

\section{Chapter 6. Forest Health Detectives: An easy tutorial to incorporate forest} vigor into biology and ecology lessons

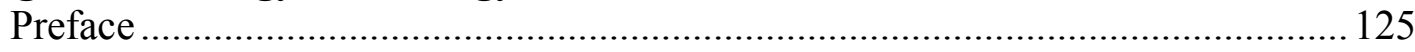

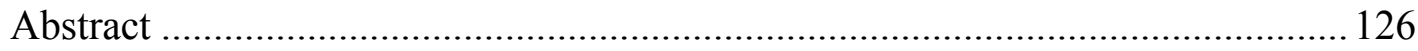

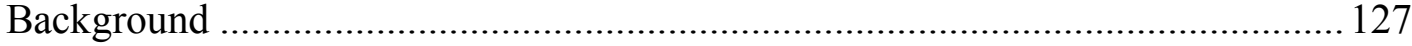

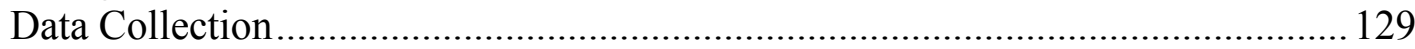

Materials and Equipment

Procedure

Time Requirements

Suggested Class Schedule

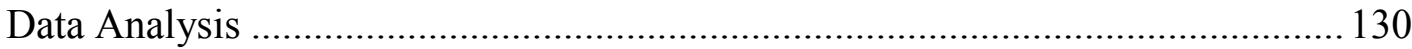

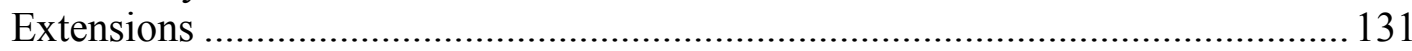

Glossary for Forest Health Detectives

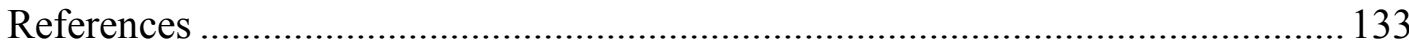

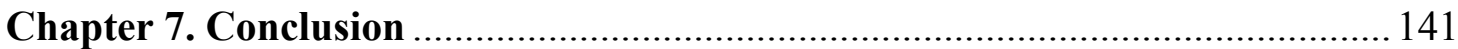

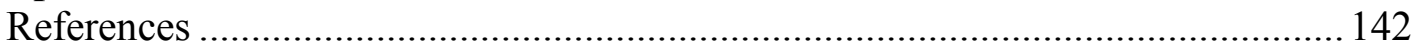

\section{Appendix A}

Forest Detectives: Insects and Diseases of the Great Lakes

Region Curriculum Developed for Grades 6-11 Summer Youth

Programs at Michigan Tech

\section{Appendix B}

Letters of Permission from journal editors 


\section{Preface}

This Dissertation is submitted for the Degree of Forest Science at Michigan Technological University. The research herein was conducted under the supervision of Drs. Andrew J. Storer, Dana L. Richter, and Martin F. Jurgensen from 2009-2013.

This work is to the best of my knowledge original, except where references and acknowledgements are made to previous work. Part of this work contains previously published material and material submitted for journal review. Chapter 5 titled The Relationship of the Sapstreak Fungus, Ceratocystis virescens, with Sugar Maple Dieback and Decay in Northern Michigan was previously published by in the American Journal of Plant Sciences (T.L. Bal, D.L. Richter, A.J. Storer, and M.F. Jurgensen, 2012, 4(2A): 436-443). Data collection and analyses were completed by Tara L. Bal. Dana Richter provided the lab space and direction for the research. Andrew Storer and Martin Jurgensen provided comments and review for publication. Chapter 6 titled Forest Health Detectives: An easy tutorial to incorporate forest vigor into biology and ecology lessons has been submitted for review to The American Biology Teacher, May 2013 by T.L. Bal. Appendix B contains copies of emails from the managing editors of both journals allowing permission for use of these articles.

The remaining chapters in this dissertation have been written as a collection of articles for future publication, thus each chapter contains its own introduction, methods, results, and conclusion sections. Each remaining chapter will be multi-authored journal publications with the bulk of writing and data analysis performed by Tara Bal. Ideas, directions, and editing will be contributed by Andrew Storer, Martin Jurgensen, Michael Amacher, and Dana Richter. 


\section{Acknowledgements}

I'd like to thank, in full, my advisor for his sound guidance while pursuing both of my graduate degrees, Andrew Storer. I have him to thank for my success in becoming an effective researcher, writer, and instructor. The rest of my committee panel and collaborators gave helpful insights and valuable information across all stages of my graduate program: Marty Jurgensen, Dana Richter, Brad Baltensperger, Michael Amacher, and for educator tips, Joan Chadde. Dana in particular helped broaden my experience with forest pathology. Marty pushed me to take those extra soil classes that came in so handy and gave us the connection with Michael out west to process all of the nutrient samples. Brandon Bal, Eric Stier, Brian Fettig, and Keith Brey of American Forest Management, Inc. were invaluable in their assistance in locating sugar maple stands with dieback and creating maps for use in the field. Funding for, and the stimulus of this project was provided by GMO Renewable Resources and I'm glad Charlie Thompson got the chance to come out on a few site visits. The Forest Service staff, especially the Forest Health Monitoring Program staff, and the MI DNR also assisted in plot establishment. Robert Heyd, MI DNR, Manfred Mielke, USFS, and Joseph O'Brien, USFS provided many early comments and assistance throughout the course of this project. Dana Richter provided assistance with fungal isolations and comparison cultures of the sapstreak fungus. Chris Webster, Michigan Tech, provided use of the tree ring reader. Andrew Burton, Michigan Tech, provided use of the leaf area measurer. Michael Amacher, Research Soil Scientist, U.S. Forest Service, Rocky Mountain Research Station, Logan, UT, has been extremely helpful by performing all nutrient analyses on the foliage and soil samples. Paul Doskey, Michigan Tech was extremely helpful providing early critique of the nutrient review. Amy Berns also helped overall with this project by working on the wood quality aspect that is vital to the resolution of management plans dealing with sugar maple dieback. I'm also incredibly grateful to the field and lab technicians throughout this project: Sally Sanderson, Jim Klapperich, Chad Fortin, Christine Jones, Melissa Porter, Donavon Young, Will Schultz, Eric Hollenbeck, Andrew Beebe, Sunshine Love, Blaine Stormer, Ellis Adams, Alex Larsen, Kurt Lehman, Jonathon Malette, Anne Collins, Karen Cladas and the SLAM crew occasionally, and of course, my family, Brandon and Jeremiah Bal, Acer and Tsuga! 


\section{Abbreviations}

BAI -Basal Area Increment: a measurement of annual tree growth that takes into account tree size as growth slows with increasing age and size

DBH -Diameter at Breast Height: standard tree diameter measured 1.3m above ground

ICP -Inductively Coupled Plasma mass spectrometry: a measurement technique used to detect ion concentrations

NOAA -National Oceanic and Atmospheric Administration

RI -Ring Increment: the raw annual tree ring measurement representing one year's growth

RMRI -Recent Mean Radial Increment: the mean ring increment for a recent period of growth (typically the previous 5 or 10 years) 


\section{Abstract}

Sugar Maple, Acer saccharum Marsh., is one of the most valuable trees in the northern hardwood forests. Severe dieback was recently reported by area foresters in the western Upper Great Lakes Region. Sugar Maple has had a history of dieback over the last 100 years throughout its range and different variables have been identified as being the predisposing and inciting factors in different regions at different times. Some of the most common factors attributed to previous maple dieback episodes were insect defoliation outbreaks, inadequate precipitation, poor soils, atmospheric deposition, fungal pathogens, poor management, or a combination of these. The current sugar maple dieback was evaluated to determine the etiology, severity, and change in dieback on both industry and public lands. A network of 120 sugar maple health evaluation plots was established in the Upper Peninsula, Michigan, northern Wisconsin, and eastern Minnesota and evaluated annually from 2009-2012. Mean sugar maple crown dieback between 2009-2012 was 12.4\% (ranging from 0.8-75.5\%) across the region. Overall, during the sampling period, mean dieback decreased by $5 \%$ but individual plots and trees continued to decline.

Relationships were examined between sugar maple dieback and growth, habitat conditions, ownership, climate, soil, foliage nutrients, and the maple pathogen sapstreak. The only statistically significant factor was found to be a high level of forest floor impacts due to exotic earthworm activity. Sugar maple on soils with lower $\mathrm{pH}$ had less earthworm impacts, less dieback, and higher growth rates than those on soils more favorable to earthworms. Nutritional status of foliage and soil was correlated with dieback and growth suggesting perturbation of nutrient cycling may be predisposing or contributing to dieback. The previous winter's snowfall totals, length of stay on the ground, and number of days with freezing temperatures had a significant positive relationship to sugar maple growth rates. Sapstreak disease, Ceratocystis virescens, may be contributing to dieback in some stands but was not related to the amount of dieback in the region.

The ultimate goal of this research is to help forest managers in the Great Lakes Region prevent, anticipate, reduce, and/or salvage stands with dieback and loss in the future. An improved understanding of the complex etiology associated with sugar maple dieback in the Upper Great Lakes Region is necessary to make appropriate silvicultural decisions. Forest Health education helps increase awareness and proactive forest management in the face of changing forest ecosystems. Lessons are included to assist educators in incorporating forest health into standard biological disciplines at the secondary school curricula. 


\section{Chapter 1}

\section{Introduction}

Sugar maple (Acer saccharum Marsh.) is well recognized for its importance as a keystone forest species and to the lumber and syrup industries. In the northern hardwood ecosystem, sugar maple is the predominant tree species and its brilliant orange, yellow, and red fall foliage attracts large numbers of tourists. Because it is so important ecologically, economically, and even socially, sugar maple health is of concern on both public and private lands. During the past five decades, sporadic patches of sugar maple dieback (Figure 1.1) or decline have appeared in Ontario and Quebec, Canada, Pennsylvania, New York, New Hampshire, Vermont, Maine, Massachusetts, Connecticut, New Jersey, Minnesota, Wisconsin, and Michigan (Millers et al., 1989; Kolb and McCormick, 1993; Houston, 1999).

Dieback is defined as generally a loss or mortality of portions of a crown as a symptom due to a single factor, whereas a decline is usually defined as a loss of vigor and growth and eventual mortality due to a combination of predisposing, inciting, and/or contributing factors (Manion, 1991; Houston, 1992). Many of these dieback and decline events have been the subject of heavy scrutiny but because they typically only last for a relatively short period of time, it has been difficult to determine all of the interacting contributing factors and fully understand them. Change in forest composition due to disease and declines drastically impacts forest economics and ecological processes of multiple species (Lovett et al., 2006). The work reported here attempts to identify biotic and abiotic factors associated with sugar maple dieback currently reported in the western Upper Peninsula Michigan and across the Upper Great Lakes (MDNR, 2009, 2010, 2012). The rate of change of dieback was monitored during the study period and longterm growth trends were examined. The goal of this data collection is to assist forest managers in the Upper Great Lakes Region alleviate loss due to dieback or reduce dieback occurrence. 


\subsection{History of Sugar Maple Dieback in the Upper Peninsula, MI}

The seemingly recent symptom of heavy dieback in sugar maple has increased concern across the western Upper Peninsula, MI. Sugar maple dieback has been documented and examined across the northeast throughout the range of sugar maple especially in the last 50 to 60 years (Allen et al., 1995; Horsley and Long, 1999; Houston, 1999) but much less so in the Midwestern states (Millers et al., 1989). Questions have been raised about the cause of the dieback and relationships have been drawn to environmental disturbances, such as climate extremes, defoliation events, nutrient perturbation, and management practices in some cases. To date, the change in tree health of sugar maple in eastern parts of its range appears to be driven by local conditions, mainly predisposed by soil nutrients and incited by heavy defoliation, severe drought, or differing decades of bad winters (Horsley and Long, 1999, Horsley et al., 2000). When these stressors occur in an area with soils that are only marginally suited for sugar maple growth, they may push the limits of tree tolerance, dramatically increasing the presence of dieback.

In the Great Lakes Region, the largest reported dieback and decline was during the late 1950's to early 1960's ( 1956-1963). Dieback was reported on approximately $28 \%$ of large sugar maple and 38\% of red maples at the USFS Dukes Experimental Forest in the western Upper Peninsula of MI, and scattered dieback was reported in other areas of MN, WI, and MI. High water tables and heavy cutting were implicated at the time, but later reports also located dieback in drier sites and undisturbed areas (Millers et al, 1989; Anderson and Schmiege, 1959). In Florence County, WI, and Iron County, MI, pockets of severe dieback and mortality were reported in the late 1950s and coined 'maple blight' because of the rapid death of trees in all size classes. After 1958, the 'blight' began to subside, and only the dieback that resulted in slower deterioration was reported over the next few years. The cause of the blight was never specifically determined, but hypothesized to have resulted from heavy defoliation followed by early frosts which killed the fresh foliage (Anderson and Schmiege, 1959; Schmiege and Anderson, 1960). 
Some examinations have suggested that dieback is somewhat cyclical in occurrence. During a 6 year study at the Dukes Experimental Forest (Marquette County, MI) from 1958 to 1963, dieback in sugar maple increased from 9.7 to $27.8 \%$ of the trees with symptoms, then dropped to $18 \%$ and was noted at even lower levels afterward 1963 (Kessler, 1965). Historical records from the area in the 1920s indicate previous dieback episodes, yet the cause of any of these events has never been determined. The same area was further studied throughout the 1960's, and several hypotheses were put forward, such as soil moisture (higher water tables), logging and frost injury, overmaturity, and the sapstreak fungus (Kessler, 1967). At the time however, annual tree rings did not indicate consistent growth reductions in trees with dieback symptoms, so this was likely not a true decline. Since this time, sugar maple dieback in the Great Lakes area has been reported intermittently, but has not seemed to be as prominent as reported in recent years (Millers et al, 1989; MDNR, 2009, 2010, 2012).

\subsection{Factors Associated with Maple Dieback in Eastern Range}

More research on maple dieback has been conducted in the northeastern range of sugar maple. A ten-year assessment from 1988-1997 in northeast United States and southeastern Canada determined that in the region for the time, the sugar maple was generally healthy (Allen et al., 1999). This does not mean that dieback or decline was no longer seen on the landscape. A variety of biotic and abiotic factors have been associated with sugar maple dieback across its range and these need to be identified almost to the stand level if any forest management decisions are to be made. The most common factors associated with maple dieback in the literature are soil moisture and nutrition, highway salt, extreme weather events, atmospheric deposition, defoliating insects, sugar maple borer, Armillaria sp., and management activities (Horsley et al., 2002; Houston, 1992).

From early land records, it is known that sugar maple may now be occupying sites that were historically hemlock or pine communities, especially in the Upper Great Lakes Region. Across its entire range, sugar maple comprised its highest percentage $(\sim 50 \%)$ in pre-settlement records in the Western Great Lakes region (Whitney, 1999). 
Sugar maple's importance, distribution, and abundance have increased as it has moved into areas cleared for agriculture or sites where it previously occurred infrequently or only as a minor component (Nyland, 1999). Sugar maple was also less frequently found previously on the unglaciated Alleghany plateau, an area that has seen severe decline more recently, suggesting a corresponding decline in environmental conditions suitable for sugar maple (Bailey et al., 2004). Given these conditions, dieback or decline etiologies likely will involve changes in environmental factors or predisposition to decline by environmental factors.

\subsection{Implications of the Research Presented Here}

The current dieback in the Upper Great Lakes Region is sufficiently developed that it is clearly visible even during the winter months due to the loss of bark from branches in the upper canopy. The extent to which this dieback is related to management activities and to abiotic or biotic factors is unclear. In some areas where entries for harvests have been made, high proportions of the residual stand of crop trees have had significant dieback and mortality leading to additional entries for salvage (E. Stier, American Forest Management Inc., pers. comm.). The purpose of the research in this dissertation is to evaluate trends and rates of change in dieback in the Upper Great Lakes Region and determine the sugar maple dieback etiology. Biotic and abiotic factors including foliage and soil nutrients, management regimes, insects, fungal pathogens, and precipitation were evaluated to determine and compare the dieback etiology to other documented cases.

Forest management guidelines have been developed for areas with dieback persisting in the northeastern range of sugar maple. For example, multiple research projects have attempted to identify the cut off point for salvageable timber from trees that have dieback. Forest land managers usually note that any tree with $>75 \%$ of their crown lost are not likely to survive and that trees with $50-75 \%$ are probably at high risk

of mortality (Smith, 2000). Hall et al., (1999) reports that trees with $>35 \%$ dieback have the lowest probability of survival, while trees with $0-15 \%$ dieback have the greatest chance at recovery and long term survival. Others also report $35-40 \%$ dieback as 
generally being the highest level a tree can withstand and still be able to recover within a few years (Gross, 1991; Allen et al., 1995). Few forest management plans in the Great Lakes Region regularly account for maple dieback. With the high levels of current sugar maple dieback in the region, and factors that increase dieback likely to continue, managers need to have appropriate information available for the region they work in.

In addition to the sugar maple health research, lesson plans and activities for public and youth to become familiar with forest health topics are included. 'Forest Health' is an important concept often not covered in basic tree, forest, insect, or fungal ecology and biology but vital to successful forest management (e.g. Glenn and Dickmann, 2009). A variety of indoor and outdoor lessons and a packet of resources for educators that stresses forest health are attached, especially native pests and diseases of the Great Lakes region that are straightforward to identify and use in classes relating to forest health. A week-long curriculum for the Michigan Tech Summer Youth Program in Forest Health was also developed and is made available that could be adopted for any school or camp group. Both of these lesson plans have been successfully implemented either in part or whole for a variety of classes (k-12) in the Western Upper Peninsula and have been developed with feedback from teachers and students.

\subsection{References}

Allen, D.C., Molloy, A.W., Cooke, R.R., Lachance, D., Barnett, C. 1995. North American maple project, seven year report. USDA Forest Service, Northeast State and Private Forest Station. 57 p.

Allen, D.C., Molloy, A.W., Cooke, R.R., Pendrel, B.A. 1999. A ten-year regional assessment of sugar maple mortality. In Proceedings of sugar maple ecology and health: An international symposium. Warren, MI. June 2-4, 1998. USDA Forest Service Gen. Tech. Rep. NE-261 pgs 27-45.

Anderson, G.W., Schmiege, D.C. 1959. The forest insect and disease situation Lake States 1958. USDA For. Ser. Station Paper No 70.

Bailey, S.W., Horsley, S.B., Long, R.P., Hallett, R.A. 2004. Influence of edaphic factors on sugar maple nutrition and health on the Alleghany Plateau. Soil Sci. Am. J. 68: 243-252.

Glenn, D.D., Dickmann, D.I. 2009. Forestry field studies: a manual for science teachers. National Science Teachers Association Press, Arlington, VA. 102 pp.

Gross, H.L. 1991. Dieback and growth loss of sugar maple associated with defoliation by the forest tent caterpillar. Forest Chron. 67(1):33-42. 
Hall, T.J., Unger, J.D., Bast, T.C., Kauffman, N.C., Regester, B.S., 1999. Factors associated with rapid mortality of sugar maple in Pennsylvania. In Proceedings of sugar maple ecology and health: An international symposium. Horsley, S.B. and Long, R.P. (Eds) 1999. MI. June 2-4, 1998. USDA Forest Service Gen. Tech. Rep. NE-261 pgs 51-54.

Horsley, S.B., Long, R.P.,(Editors) 1999. Sugar maple ecology and health: An international symposium. Warren, MI. June 2-4, 1998. USDA Forest Service Gen. Tech. Rep. NE-26.

Horsley, S.B., Long, R.P., Bailey, S.W., Hallett, R.A., Hall, T.J. 2000. Factors associated with the decline disease of sugar maple on the Allegheny Plateau. Can J. For. Res. 30: $1365-1378$.

Horsley, S.B., Long, R.P., Bailey, S.W., Hallett, R.A., Wargo, P.M. 2002. Health of Eastern North American sugar maple forest and factors affecting decline. North. J. Appl. For. 19(1): 34-44

Houston, D.R. 1992. A host-saprogen model for forest dieback-decline diseases. P. 3-25 in Forest decline concepts, Manion, P.D., and Lachance D., (eds.). APS Press, New York.

Houston, D.R. 1999. History of sugar maple decline. In Proceedings of sugar maple ecology and health: An international symposium. Horsley, S.B. and Long, R.P. (Eds) 1999. MI. June 2-4, 1998. USDA Forest Service Gen. Tech. Rep. NE-261 pgs 19-26.

Kessler, K.J. Jr., 1965. Dieback of managed, old growth northern hardwoods in upper Michigan, 1954-1964: A case history. Plant Dis. Rep. 49: 483-486.

Kessler, K. J., 1967. Dieback not a cause of mortality or reduction of growth or quality in Lake states northern hardwoods. J. Forest. 65: 892-893.

Kolb, T.E., McCormick, L.H. 1993. Etiology of a sugar maple decline in four Pennsylvania stands. Can. J. For. Res. 23: 2395-2402.

Lovett, G.M., Canham, C.D., Arthur, M.A., Weathers, K.C., Fitzhugh, R.D. 2006. Forest Ecosystem responses to exotic pests and pathogens in eastern North America. BioScience 56(5): 395-405.

Manion, P.D. 1991. Tree disease concepts. Prentice-Hall, Englewood Cliffs, NJ.

Michigan Department of Natural Resources and Environment, Forest Management Division, 2009 Michigan Forest Health Highlights. http://fhm.fs.fed.us/fhh/fhh_09/mi_fhh_09.pdf

Michigan Department of Natural Resources and Environment, Forest Management Division, 2010 Michigan Forest Health Highlights. http://fhm.fs.fed.us/fhh/fhh_10/mi_fhh_10.pdf

Michigan Department of Natural Resources and Environment, 2012. Forest Management Division, 2012 Michigan Forest Health Highlights http://www.midnr.com/Publications/pdfs/ForestsLandWater/ForestHealth/FHH.pdf

Millers, I., Shriner, D.S., Rizzo, D. 1989. History of hardwood decline in the Eastern United States. USDA Forest Service, Northeastern Forest Exp. Station, Gen. Tech. Rep. NE-126. Broomall, PA, 75 p.

Nyland, R.D. 1999. Sugar maple: its characteristics and potentials. In Proceedings of sugar maple ecology and health: An international symposium. Horsley, S.B. and 
Long, R.P. (Eds) 1999. MI. June 2-4, 1998. USDA Forest Service Gen. Tech. Rep. NE-261 pgs 1-13.

Schmiege, D.C., Anderson, G.W. 1960. The forest insect and disease situation, Lake States, 1959. USDA For. Ser. Station Paper No 79.

Smith, W.H. 2000. Ice and forest health. North. J. Appl. For. 17:16-19.

Whitney, G.G. 1999. Sugar maple: abundance and sites relationships in the pre- and postsettlement forest. In Proceedings of sugar maple ecology and health: An international symposium. Horsley, S.B. and Long, R.P. (Eds) 1999. MI. June 2-4, 1998. USDA Forest Service Gen. Tech. Rep. NE-261 pgs 14-18. 


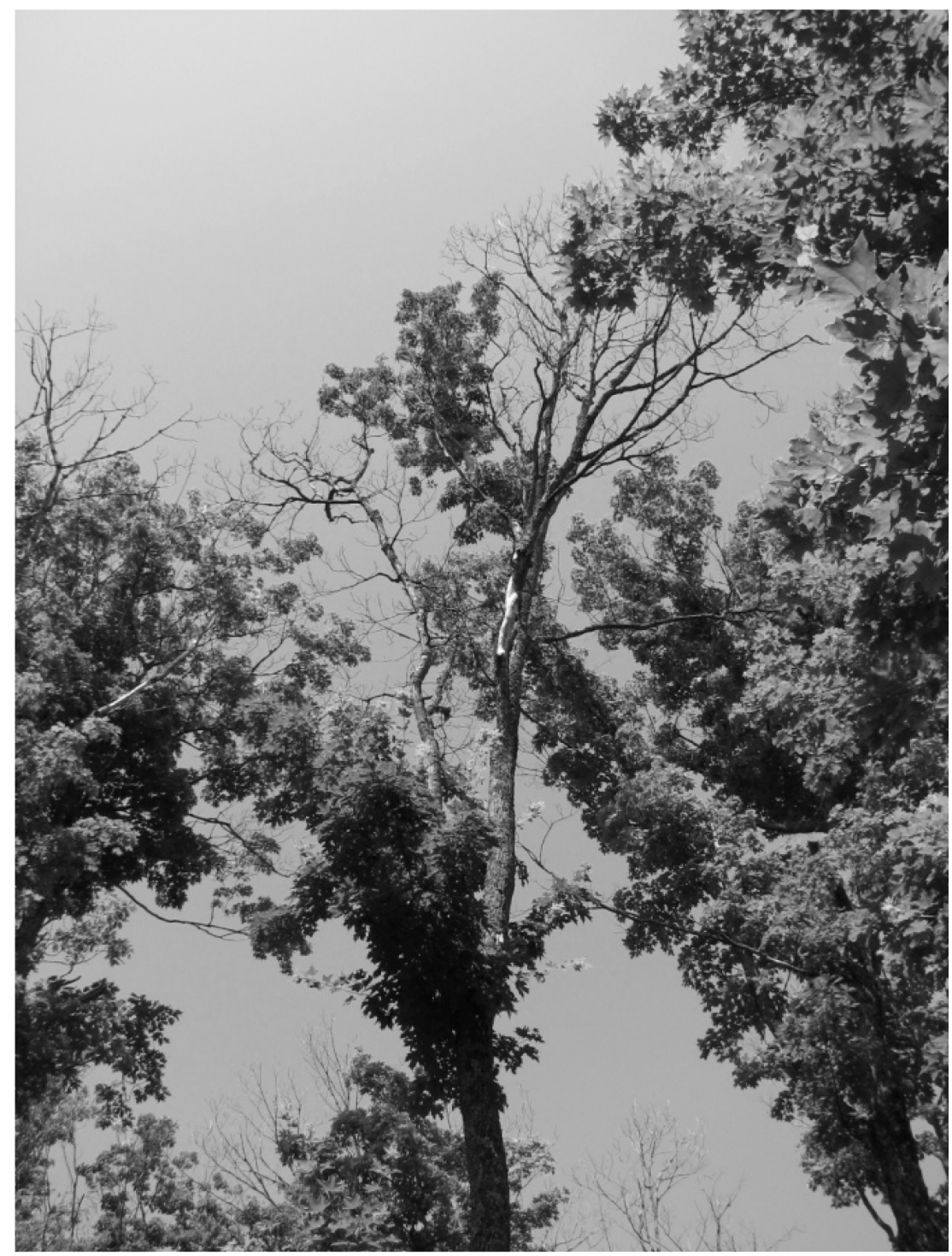

Figure 1.1. Sugar maple crown dieback in Keweenaw County, MI, 2009. Photo by Tara Bal 


\title{
Chapter 2
}

\section{Sugar Maple Dieback Trends in the Western Upper Great Lakes Region $^{1}$}

\begin{abstract}
Sugar maple (Acer saccharum Marsh.) is important both economically and ecologically in northern hardwood forest ecosystems in North America. Crown dieback of sugar maple in the western Upper Great Lakes region has increasingly been reported relative to recent decades by stand managers and agencies. A network of sugar maple health evaluation plots were established across Upper Michigan, northern Wisconsin, and eastern Minnesota on a variety of soil types and with variable mean dieback levels on public and industry owned lands though Western Upper Michigan and eastern Minnesota plots have had lower mean basal area increments (BAI) than eastern Upper Michigan and northern Wisconsin. Sugar maple dieback symptoms were evaluated from 2009 to 2012 and relationships were examined between dieback, radial growth, plot location, and climate variables. The mean plot dieback level decreased from $14 \%$ to $9 \%$ from 2009 2012. There were no significant differences in dieback symptoms between public and private industry owned stands. Radial growth (BAI) has been increasing since 1900, while trees currently with the greatest amount of dieback consistently having smaller mean BAIs since 1900. Furthermore, greater than $40 \%$ of cored trees had decreasing BAIs relative to the most recent and previous 5 and 10 year periods (2000-2004: 20052009, 1990-1999: 2000-2009). For trees with reduced relative growth, mean BAI decreased by approximately $15 \%$. The previous year's mean total snowfall and number of days with below freezing temperature have a positive, significant relationship with the mean BAI across the study area. Warming winter temperatures and reduced snowfall are likely influencing sugar maple growth and crown conditions across western Great Lakes
\end{abstract}

1 The material in this chapter is planned for submission in the near future and is formatted as such. 
region. Further examination into stand level conditions, such as soil fertility and biotic stress factors, need to be examined.

\section{Introduction}

Episodes of decline and dieback of sugar maple have been documented and examined across the northeastern United States throughout the range of sugar maple, especially in the last 50 to 60 years (Horsley and Long, 1999; St. Clair et al., 2008). The causes of the dieback and increased mortality have in some cases related to environmental disturbances, such as climate, defoliation events, nutrient perturbation, and management practices (Miller et al., 1989; Horsley and Long, 1999; St. Clair et al., 2008). Unusually high levels of dieback of sugar maple (Acer saccharum Marsh.) have recently been reported in the western Upper Peninsula of Michigan and other areas in the North Central region (Michigan Department of Natural Resources, 2009, 2010, 2012). The extent to which the current dieback is related to management activities and to abiotic or biotic factors is unclear, but in some areas, high proportions of crop trees have significant dieback and mortality. Within this region, sugar maple is one of the most abundant, widespread, and valuable timber species in the northern hardwood forests.

In the eastern range of sugar maple, changes in tree health appear to be driven by local conditions, often with imbalances in soil nutrients predisposing trees to loss of vigor that results from heavy defoliation or climate perturbations (Manion and LaChance, 1992; Horsley and Long, 1999). Specific climatic events predisposing sugar maple to dieback or decline include reduced soil moisture in summer or fall, general drought, extreme winter temperatures, extreme growing season temperatures, low snow cover, early winter thaw with frost damage to foliage and buds, and frost damage to roots (e.g. Auclair, 1988; Kelley, 1988; Bauce and Allen, 1991; Graumlich, 1993; Payette et al., 1995; Burton et al., 1998; Tierney et al., 2001). When these events occur in an area with marginal soils for sugar maple, an increase in the presence of dieback may occur (Houston, 1992; Manion and Lachance, 1992).

Diameter growth can be affected by stressors such as competition for available light, nutrients, moisture, and other environmental conditions (McClenahen, 1995), and 
trees that exhibit dieback may have decreased diameter growth for 10 to 20 years before the onset of canopy symptoms (Kolb and McCormick, 1993; Duchesne et al., 2002, 2003). Crown dieback is a significant growth stressor, reducing photosynthesis and food reserves and leaving trees more vulnerable to contributing factors of decline (Manion, 1991; Houston, 1981).

Studies on sugar maple dieback have focused on stands in the northeastern portion of the range of sugar maple, including New England, Quebec, and southern Ontario, with fewer studies in the western Great Lakes region where there have been fewer reports of dieback until recently (Millers et al., 1989; Michigan Department of Natural Resources, 2009, 2010, 2012). The northern hardwoods in the western Great Lakes may have different combinations of factors impacting growth from those in the northeastern portion of the range of sugar maple due to differences in forest composition, soil types, glacial history, defoliation and disturbance regimes.

In the Great Lakes Region, the largest reported dieback occurred during the late 1950s to early 1960s ( 1956-1963) (Millers et al., 1989). Dieback was reported on approximately $28 \%$ of large sugar maples and $38 \%$ of red maples in the western Upper Peninsula of Michigan, and scattered dieback was reported in other areas of Minnesota, Wisconsin, and Michigan though what size trees were impacted or the proportion that recovered is unknown (Millers et al., 1989). High water tables and heavy cutting were implicated at the time (Anderson and Schmiege, 1959), but later reports in the Lake States described dieback due to drought conditions and biotic stressors (Millers et al., 1989). In Florence County, Wisconsin, and Iron County, Michigan, pockets of severe dieback and mortality were reported in the late 1950s and the name 'maple blight' was coined because of the rapid death of all sizes of trees (Anderson and Schmiege, 1959; Schmiege and Anderson, 1960). After 1958, the 'blight' began to subside though the cause was never specifically determined, however, it was hypothesized to result from heavy defoliation from maple webworm (Tetralopha asperatella Clemens) followed by early frosts that killed the new foliage (USDA, 1964; Houston 1999). Since this time, sugar maple dieback in the Great Lakes area has been reported intermittently (Millers et al., 1989). 
Diameter growth of sugar maple in New England from 1950 to 1980 did not decrease prior to reports of increasing dieback in the early 1980's (Hornbeck et al., 1988). However, diameter growth of sugar maple in eastern Minnesota and western Upper Michigan was reduced through the 1980s, although this was reported to not to be associated with tree decline (Lane et al., 1993). Additional reports of reduced diameter growth of sugar maple in the eastern part of its range, especially since the 1980s, have generally attributed the reduced growth to either climatic or defoliation events, and/or poor site fertility (Houle, 1990; Bauce and Allen, 1991; Kolb and McCormick, 1993; Ryan et al., 1994; Payette et al., 1995; Watmough et al., 1999; Long et al., 2009).

Reports of sugar maple dieback in and around Upper Michigan have come from multiple locations and on multiple ownerships. The current dieback may be of greater severity and geographic scope than previously reported episodes, and other compounding factors, including climate change, may be contributing to the observed patterns of decline. The objectives of the work presented here are to:

1. Characterize changes in dieback symptoms in sugar maple from 2009 to 2012.

2. Determine whether dieback is associated with reduced radial growth of sugar maple

3. Characterize relationships between dieback, growth, location, ownership, and weather patterns.

4. Determine factors contributing to the current dieback etiology.

\subsection{Study Region}

The sugar maple health assessment plots were distributed on private industry (61 plots) and public state and federal forest lands (59 plots) across the western upper Great Lake States (Figure 2.1, 2.2). Of the original 120 plots established in 2009 and 2010, 118 were visited for all subsequent years. No stands had evidence of known sugarbush activity. Evidence of some level of repetitive selection harvesting could be found across all ownerships and sites, but quality harvest history data was lacking. Fourteen of the plots had at least one tree harvested during evaluation years and those trees were removed from subsequent analyses. Stand density varied between 174 and $870 \mathrm{~m}^{2}$ basal area per hectare with an average of $435.6 \mathrm{~m}^{2}$. The deciduous and coniferous trees most commonly 
associated with the sugar maple forest type varied between intermediate and suppressed trees, and dominant and co-dominant canopy classes (Table 2.2). American beech (Fagus grandifolia Ehrh) was found only in plots located in far eastern Upper Michigan. During the four year evaluation period, a total of 2120 sugar maple trees $\geq 10 \mathrm{~cm}$ dbh were assessed. Approximately half of these were initially assessed in 2009, and the majority of all trees in the study were assessed annually from 2010 to 2012.

\section{Methods}

\subsection{Plot Establishment and Base Measurements}

A network of 120 forest evaluation plots was established across the Western Upper Great Lakes Region. Sixty of these plots were established on private industry land in the Upper Peninsula, Michigan in 2009 (Marquette, Baraga, Houghton, and Keweenaw Counties) and 60 were established on public lands in Upper Michigan, northern Wisconsin and Minnesota in 2010 (Figure 2.1). Plots were revisited annually until 2012. Plot locations were not random, but were in stands identified by National Forest staff, Michigan Department of Natural Resources, and industry foresters as being dominated by maple and other hardwoods and having varying degrees of dieback.

Circular 0.04 ha plots were located at least $40 \mathrm{~m}$ from established roadways to minimize edge effects and in most cases included at least 10 sugar maple trees. All trees greater than or equal to $10 \mathrm{~cm}$ diameter breast height (dbh) were measured, permanently marked and located relative to the plot center. The canopies of all trees were assessed using standard Forest Health Monitoring Protocols (USDA, 1999) to determine height, crown class, uncompacted live crown ratio, foliage transparency, canopy density, and crown dieback. In the years after establishment, trees that had grown large enough were tagged and added to the plot measurements. Crown dieback was estimated as the percentage of the whole crown that had dieback (0-99\%, estimated to $1-5 \%$ intervals), including recently dead branches, peeling branches or bark, or fine branches that do not have growing buds in the upper and outer portions of the crown.

When calculating the mean sugar maple dieback for plots in each year, trees that were harvested were no longer included (11 of 120 plots had at least one tree removed 
during the study period but no plots were completely harvested). Trees that were dead during the plot establishment year were recorded as having $100 \%$ dieback but were not included in the plot mean canopy dieback for that year. Mortality that occurred after the plot was established was included in the plot mean to capture the dead and dying trees.

\subsection{Tree Cores}

From 2009-2011, a subset of plots was visited to obtain increment cores. At each plot, three trees in a similar size class (ideally within $5 \mathrm{~cm} \mathrm{dbh}$ ) were sampled. These trees were selected to include one with little to no dieback, one with intermediate dieback for the plot, and one with high dieback relative to the average dieback in the plot to increase the variability of dieback sampled. All cores were from dominant or codominant canopy trees to reduce the likelihood of partial or missing rings (Lorimer et al., 1999).

For each of the three trees that were cored in each plot, two increment cores were collected at 90 degrees to one another at $\mathrm{dbh}(1.4 \mathrm{~m})$ for growth analysis and to determine the age of the tree where possible. Cores were refrigerated until being mounted on wooden increment core holders and sanded. Annual ring widths were measured on a digital measuring stage to the nearest $0.001 \mathrm{~mm}$ using the Measure J2X software (VoorTech Consulting LLC, Nolderness, NH, 1999). Cores were visually cross dated and cores that had significant decay or that were otherwise unreadable were excluded. Data from the two cores from each tree were averaged per year per tree for comparison with climate and other data. While the age of a few individual trees were from well into the 1800 s, no analysis of growth ring data was done for growth before 1900 to eliminate noise in the data series due to juvenile growth, smaller sample sizes, and the availability of climatic data from that time period. For these reasons, analyses completed between recent (2009-2011) and historic dates $(1900,1905,1930$, or 1963) are noted. Growth chronologies were constructed as mean annual raw ring increment (RI) ( $\mathrm{mm}$ ) and mean annual basal area increment (BAI) $\left(\mathrm{cm}^{2}\right)$ using the equation:

$$
\mathrm{BAI}_{\mathrm{t}}=\pi\left(\mathrm{R}_{t}{ }_{t}-\mathrm{R}_{t-1}{ }\right)
$$

where $\mathrm{R}$ is the tree radius at $\mathrm{dbh}(\mathrm{cm})$ and $t$ is the year of tree ring formation. 
The primary goal of collecting such a wide variety of cores was to identify patterns in ring width chronologies of trees reported with recently high levels of crown dieback and determine if commonly reported factors that reduce growth are impacting sugar maples in the Western Great Lakes region. A variety of age and size classes was collected to help alleviate potential decrease in growth due to maximum age and ensuring a varied history of competition and release over the study area. Basal area increment is not expected to decrease for sugar maple trees until they are over 100-110 years old (Duchesne et al., 2003) and greater than $45 \mathrm{~cm}$ (17in) d.b.h. (Lorimer and Frelich, 1984). This type of analysis assumes microvariation in ring widths would not significantly impact overall trends in growth. Maple rings are notoriously hard to see and cores have been shown to have partial or missing rings, but dominant, codominant, and intermediate canopy trees have very few (less than 5\%) ring anomalies (Lorimer et al., 1999).

\subsection{Climate Data}

Weather data for Upper Michigan, northern Wisconsin and eastern Minnesota was obtained from the National Oceanic Atmospheric Administration Climatic Data Center (NOAA, 2012). Weather stations were selected based on proximity to sugar maple evaluation plots (Figure 2.1) and the availability of at least 5-10 years of data (Table 2.1A, 2.1B). Data were only used for each year if measurements were available for the full year. Precipitation, snowfall, temperature, number of days above freezing and number of days with snow cover data were available for most stations for most years. Certain records, such as days with snow cover, were only available for a few years for some weather stations.

\subsection{Statistical Procedures}

To determine relationships between ownership type, subregion (east and west Upper Michigan, northern Wisconsin, and eastern Minnesota) climatic trends, and the level of crown dieback and ring widths, ownership was divided into public lands and private industry lands, the latter of which has been managed as industry since stand initiation. Difficulties exist in separating effects of management and ownership type 
however, due to the industry land being primarily located in Houghton, Keweenaw, Baraga, and Marquette Counties, MI, while the public land evaluated had much wider regional distribution. Thus differences between ownership type were not considered in other analyses.

For analyses of RI and BAI, tree cores were grouped by percentage of dieback in the categories $0-25 \%, 26-50 \%$, and $51-99 \%(\mathrm{n}=225,53,35$ per dieback category respectively). The significance of differences in the mean annual BAI between ownership type, regional location, and mean dieback category were tested using a repeated measure ANOVA. Mean crown dieback was assessed with a one-way analysis of variance. Proportions of trees increasing or decreasing in dieback during the study period were evaluated with a chi-square test. Linear regressions were used to evaluate the relationship between crown variables and dieback and also climate variables and mean BAI for the following year. To compare relative BAI, the mean BAI was calculated for the most recent and previous 5, 10, and 20 year periods starting in 2009. Tukey's procedure for all pairwise comparisons was used to compare ring data between dieback, ownership, and regional categories $(\alpha=0.05)$. Plot averages were not transformed as the mean and the variances were independent (Allen et al., 1992). All statistical analyses were carried out using the software Statistix 9.1 (C1985-2008).

\section{Results}

\subsection{Dieback Occurrence}

There were significant differences in plot mean sugar maple dieback between years $(\mathrm{p}<0.001)$, generally increasing until 2011 and declining in 2012 (Figure 2.2). There was no significant difference in mean crown dieback for any year between ownership types (pooled mean dieback; industry lands=13.1\%, public lands $11.7 \% ; \mathrm{p}=$ 0.339). The 2010 mean dieback of sugar maple on the industry lands had overall decreased from 2009 by 1.3\%, peaked in 2011, and fell to a four year low in 2012, with public lands following a similar trend (Figure 2.2). During 2009-2012, mean sugar maple dieback in plots (excluding trees that were dead at the start of the study) decreased from $14 \%$ to $9 \%$. Mean sugar maple dieback pooled across years ranged from $3.3 \%$ to $67.5 \%$ 
in individual plots. Approximately $14 \%$ of sugar maple trees had $\geq 20 \%$ dieback in 2010 and $7.5 \%$ had $\geq 20 \%$ dieback in 2012 while $31 \%$ and $11 \%$ of sugar maples had $\geq 10 \%$ dieback in 2010 and 2012 respectively.

Each category of dieback had approximately at least 1 in 3 trees increase in dieback from 2010-2012 (Table 2.3). The chances of a tree increasing in dieback over

time were dependent on the initial dieback measurement of the tree $\left(\chi^{2}=162.52\right.$, d.f. $=4, p$ $<0.001)$. Trees initially greater than $75 \%$ dieback continued to decline. Trees with 25 $75 \%$ dieback tended to decrease dieback levels or have no change, while trees with 5$25 \%$ dieback improved overall. Trees initially with $1-5 \%$ dieback were more likely to increase in dieback ratings from 2010-2012.

Mean crown conditions for sugar maple varied between plots with mean crown transparency following the same pattern as dieback and mean crown density being almost the inverse (Figure 2.3). Foliage density and transparency mean plot values for each year have significant linear correlations with mean dieback plot values except 2009 density and 2011 transparency (all others, $\mathrm{p}<0.05$ ).

\subsection{Relationship between Dieback and Growth}

A total of 313 sugar maples had two averaged increment core samples. Mean age of trees cored to the center was 69 years (min 30 , max 174 ) and mean dbh was $24.4 \mathrm{~cm}$ (min $10.2 \mathrm{~cm}$, max $54.6 \mathrm{~cm}$ ). Mean RI rapidly increased until the 1940's (most likely representing stand initiation and early growth periods) but has since been decreasing (Figure 2.4A). However, mean BAI for all sugar maple trees in the region has been on an increasing trend with few static periods since early last century (Figure 2.4B).

The level of dieback of cored sugar maples ranged between 0 and $99 \%$, with a mean of $18.7 \%$ crown dieback. Trees with $>50 \%$ dieback have had consistently smaller mean BAI's since 1900 than trees with less dieback (Figure 2.5). The mean BAI for category of dieback since 1900 are significantly different from each other (for each comparison of dieback categories, $\mathrm{p}<0.001$, ANOVA followed by Tukey's HSD test). Though the overall trend in mean BAI in the region is increasing, individual trees are declining in BAI (Table 2.4). More than $40 \%$ of trees cored decreased in mean relative 
BAI since 1990 and $30 \%$ of trees decreased in mean relative BAI decreased over a 20 year increment (1970-1989: 1990-2009). Mean relative BAI decreased between 14 and $16 \%$, depending on the timeline.

\subsection{Relationship between Climate, Location, and Growth}

Sugar maple diameter growth for industry lands has been significantly lower than public lands since 1900 (Figure 2.6; $\mathrm{p}<0.001$ ). Inversely, average snow depths from weather stations near industry land plots have been significantly greater $(p<0.001)$ than from surrounding areas. Mean BAI chronologies separated by subregion (eastern Minnesota, northern Wisconsin, eastern Upper Michigan, and western Upper Michigan) were significantly different from each other (Tukey's, $p<0.001$ ), independent of ownership (Figure 2.7). Climatic variables are likely influencing tree growth differently across the region as evidenced by mean yearly snowfall data from the western Upper Peninsula compared to the surrounding regions. (Figure 2.6). Mean sugar maple BAI from western Upper MI and eastern MN are not significantly different from each other, while northern WI and eastern Upper MI were not significantly different.

The impacts of management and ownership type are likely masked by plot location and climate variability. Distribution of the industry owned lands are primarily in the Western Upper Peninsula (Figure 2.1), an area with historically heavy lake effect snow (Scott and Huff, 1996). Elevation values (Table 2.1A) indicate the variation in topography across the study region further influencing microclimate. Therefore, the management influence on growth and dieback could not be differentiated completely from geographic effects.

Total precipitation and snowfall values have had consistent interannual variation throughout the region with the 1930s-1950s being a relatively dry period, followed by a wetter than average period from the late 1970s-1990s, and decreasing precipitation trend since 2000 (Figure 2.4). A decline in precipitation and snowfall values in the 1920s and 30s coincides with a decrease in RI and a period when BAI did not increase. The trend in increased precipitation values since the 1940s is reflected in an overall increase in 
diameter growth. Since the 1990s, precipitation and snowfall values have been declining, with a corresponding decrease in RI and more constant BAI (Figure 2.4).

There were significant relationships between sugar maple growth, total snowfall, the mean number of below freezing days annually, and the mean number of days with snow cover $>2.5 \mathrm{~cm}$ (Figure $2.8,2.9$ ). Total annual precipitation was not significantly related to mean annual RI or BAI ( $\mathrm{p}=0.723$ and 0.208 respectively). Mean snowfall totals had a significant positive linear relationship with RI and BAI the following growing season $(\mathrm{p}<0.001)$. The mean annual number of days below freezing was also positively significantly related with the subsequent mean RI and BAI $(p<0.001)$. The number of days with snow cover, while significantly related to both measures of growth may be more important for trees of different size classes as the relationship with BAI has a negative slope (Figure 2.9). The years 1998-2001 and 2011 had the record lowest number of days with snow cover for the region since records are available (Figure 2.10).

\section{Discussion}

Mean sugar maple dieback values ranged from apparently healthy to considerably unhealthy in plots across the study area. Mean plot dieback values over $10 \%$ are usually indicative of unhealthy trees and values over $20 \%$ are typically considered high to severe (e.g. Allen et al., 1992; Horsley and Long, 1999). Though the mean dieback overall decreased during the years of this study, dieback in many plots and specific trees rapidly increased (Table 2.3). In a sugar maple study in Ontario (1986-2004), the mean decline index (visual estimation of tree health) had likewise generally decreased but had occasional peaks every 10-15 years (Miller and Watmough, 2009). Interannual variation in precipitation and data collection timing may be influencing the amount of foliage in crowns and masking dead twigs. If the etiology of dieback is gradual, such as a nutrient deficiency that happens over decades, dead branches will snap off, reducing reported dieback levels (Watmough et al., 1999). Total crown volume reduction is not evaluated or detected in an annual survey for dieback. In addition, harvesting removed some trees present with heavy dieback. The declining relative BAIs in $30-40 \%$ of trees is evidence of decline that is not necessarily being picked up by mean dieback values. 
The majority of trees with heavy dieback would be expected to be unable to recover as is evident in the $75-99 \%$ category (Table 2.4). However, more than half the trees within the $50-74 \%$ category actually decreased in dieback $\%$ since 2010 . One explanation for this could foliage flushes masking dieback or dead branches breaking out of trees. Also, this measure does not reflect the amount of decreased dieback, which may only differ by 1 to $5 \%$, so trees with lower dieback levels may not necessarily be recovering. Furthermore, trees with the lowest levels of dieback in 2010, had a greater than $50 \%$ chance of increasing in dieback in two years, suggesting that variables or factors behind poor crown conditions are still currently influencing trees.

A similar evaluation of more than 1000 sugar maples across a wide regional area for the North American Sugar Maple Project found an average plot percent sugar maple dieback between 6-9\% in 1988-1990 and were considered generally healthy (Allen et al., 1992). The higher average crown dieback here suggests that stresses impacting trees currently in the Upper Great Lakes Region may be ongoing or more severe.

Overall, trees with the greatest diameter growth trends had the least amount of average crown dieback but also the steepest decline in BAI in the most recent years. Certainly, individual trees and stands within the region are declining as indicated by BAI. That trees currently with high levels of dieback have had lower BAI for at least ten decades suggests these trees are under long term stressors influencing growth or have been predisposed by their growing conditions to higher dieback from a more recent stress event.

Expected trends in healthy BAI chronologies should be increasing over time. A Wisconsin study found a similar trend of increasing growth through the 1940's, then a leveling off at southern sites and a slight decline through the 1980's in north central WI (Frelich et al., 1989). Sugar maple growth enhancement due to release is relatively gradual and may take as long as five years to peak (Jones and Thomas, 2004) thus, we did not attempt to reconstruct disturbance history. Harvesting impacts can significantly reduce maple root growth and survival (Malo and Messier, 2011).

Regional differences in forest composition may be influencing sugar maple health. Eastern Upper MI stands have beech bark disease (Fagus grandifolia, 
Cryptococcus fagisuga Lind., and Neonectria spp.) present, which can benefit sugar maple growth, (DiGregorio et al., 1999) but was unquantified during this study. The increase in relative abundance of ironwood (Ostrya virginiana (Mill) K. Koch) and decrease of more desirable species such as hemlock (Tsuga canadensis L.), northern red oak (Quercus rubra L.) and other northern hardwoods may be occuring at some sites.

For northern hardwoods and other tree species (Schaberg et al., 2005), snow cover depth and duration not only plays an important role in protection of roots from freeze/thaw damage (mortality) (Auclair et al., 1996; Decker et al., 2003), but also affects rates of nitrification (Groffman et al., 2001; Tierney et al., 2001) and soil acidification, increasing Al oxides (Boutin and Robitaille, 1995). Lower levels of snow and increased soil freezing reduces leaf water potential and foliar nitrogen and calcium the following growing season, forcing earlier leaf senescence (Pilon et al., 1994).

The year 2002 had a higher number of days with snow cover, however, 2001 was also the last year of a forest tent caterpillar (Malacosoma disstria Hübner) outbreak in the Upper Peninsula, causing heavy defoliation (MI DNR, 2002). Trees may have been able to recover from increased root stress only to be stressed from the top down. The increase in days with snow cover and number of frozen days in 2008 and 2009 may be reflected in the relative increase in RI and BAI around 2010 as roots were most likely better protected the previous winter.

Temperature and snow levels may be more important for sugar maple in the western Great Lakes region than total precipitation (Lane et al., 1993). A greater number of days below freezing temperature with snow cover on the ground would represent less of a risk for root damage during freeze/thaw events in the soil. Warmer, drier summers are predicted to increase and intensify, perhaps with greater total precipitation some years but not evenly distributed over the growing season (Huntington et al., 2009). More droughty conditions during the growing season leads to reduced growth, reduced leaf water potential and nutrient uptake (Pilon et al., 1996) and increased soil nitrification (Foster et al., 1992). In mature stands, once trees are stressed by early thaw and freeze events, they may be predisposed to further stress and injury due to warm temperatures and drought (Auclair et al., 2010). The positive and negative correlation for RIs and 
BAIs respectively with snow cover may be reflective of how the indices are calculated as RIs the raw ring width and BAI takes into account tree size.

Positively linking climate data with growth trends over a wide regional gradient is difficult as microclimates and regional differences clearly exist. Although some climatic patterns are evident, other factors associated with historical sugar maple dieback and decline need to be examined to fully understand the etiology of the current sugar maple dieback in the region.

\section{Conclusion}

Climate perturbations combined with other local site conditions has likely influenced growth of sugar maple in many stands across the Upper Great Lakes region. The reduced growth and heavy dieback seen in some stands across the western Upper Great Lakes may be parallel to predictions of sugar maple response to climate change, i.e. less snow means less sugar maple abundance and suitable habitat as roots are injured by frost damage (Iverson and Prasad, 2001; Henne et al., 2007). A recent Climate Assessment Report by the Federal Advisory Committee indicates more extreme droughts, heat waves and less precipitation events for the Midwest in the next few decades (U.S. Global Change Research Program, 2013). The interaction between climate variables, nutrient imbalances, and anthropogenic inputs need to be further studied for sugar maple and other species (St. Clair et al., 2008). Forest managers need to adopt practices that alleviate additional stresses (such as increased soil disturbance and exposure) in northern hardwood systems in anticipation of sugar maple dieback or reduced growth that may be already occurring. Vegetation indicators and soil nutrition may indicate another tree species would be better suited for a site (Horsley et al., 2008). Promoting other species may significantly alter base cation concentrations in soils (Fujinuma et al., 2005), possibly alleviating competition stress on surrounding maple. Optimal nutrition and growth requirements for other northern hardwood and coniferous species in the Great Lakes Region should be examined more extensively to match species and sites as sugar maple growth becomes limited and dieback increasingly common. 


\section{Acknowledgements}

This research was supported by GMO, LLC and the Forest Service Forest Health

Monitoring Program. The foresters at American Forest Management, Forest Service, and MI DNR were invaluable in their assistance in locating sugar maple stands with dieback.

Thanks to Chris Webster, Michigan Tech, for providing use of the tree ring reader.

Gratitude also goes to the field technicians that helped core trees and process samples:

Sally Sanderson, James Klapperich, Chad Fortin, Christine Jones, Melissa Porter,

Donavon Young, Will Schultz, Eric Hollenbeck, Andrew Beebe, Sunshine Love, Alex

Larsen, Kurt Lehman, and Jonathon Malette.

\section{References}

Allen, D.C., Barnett, C.J., Millers, I., Lachance, D. 1992. Temporal change (1988-1990) in sugar maple health, and factors associated with crown condition. Can. J. For. Res. 22: 1776-1784.

Anderson, G.W., Schmiege, D.C. 1959. The forest insect and disease situation Lake States 1958. USDA For. Ser. Station Paper No 70.

Auclair, A.D. 1988. A climate change theory of forest decline. In Woody plant growth in a changing physical and chemical environment. Proceedings of IUFRO Workshop, July 1987, Vancouver, B.C., (eds.) D. Lavender. University of British Columbia Press, Vancouver. Pp. 80-89.

Auclair, A.D., Lill, J.T., Revenga, C. 1996. The role of climate variability and global warming in the dieback of northern hardwoods. Water Air Soil Poll. 91:163- 186.

Auclair, A.D., Heilman, W.E., Brinkman, B. 2010. Predicting forest dieback in Maine, USA: a simple model based on soil frost and drought. Can. J. For. Res. 40: 687-702.

Bauce, E., Allen, D.C. 1991. Etiology of a sugar maple decline. Can. J. For. Res. 21: 686693.

Boutin, R., Robitaille, G. 1995. Increased soil nitrate losses under mature sugar maple trees affected by experimentally induced deep frost. Can. J. For. Res. 25: 588-602.

Burton, A.J., Pregitzer, K.S., Zoog, G.P., Zak, D.R. 1998. Drought reduces root respiration in sugar maple forests. Ecol. Appl. 8(3): 771-778.

Decker, K.M., Wang, D., Waite, C., Scherbatskoy, T. 2003. Snow removal and ambient air temperature effects on forest soil temperatures in Northern Vermont. Soil Sci. Soc. Am. J. 67: 1234-1243.

Duchesne, L., Ouimet, R., Houle D. 2002. Basal area growth of sugar maple in relation to acid deposition, stand health, and soil nutrients. J. Environ. Qual. 31: 1676-1683.

Duchesne, L., Ouimet, R., Morneau, C. 2003. Assessment of sugar maple health based on basal area growth pattern. Can. J. For. Res. 33: 2074-2080.

Frelich, L.E., Bockhem. J.G., Leide, J.E. 1989. Historical trends in tree-ring growth and chemistry across an air-quality gradient in Wisconsin. Can. J. For. Res. 19: 113-121. 
Foster, N.W., Morrison, I.K., Yin, X., Arp, P.A. 1992. Impact of soil water deficits in a mature sugar maple forest: stand biogeochemistry. Can. J. For. Res. 22: 1753-1760.

Fujinuma, R., Bockheim, J., Balser, N. 2005. Base-cation cycling by individual tree species in old-growth forests of Upper Michigan, USA. Biogeochemistry 74: 357376.

Graumlich, L.J. 1993. Response of tree growth to climatic variation in the mixed conifer and deciduous forests of the upper Great Lakes region. Can. J. For. Res. 23: 133-143.

Groffman, P.M., Driscoll, C.T., Fahey, T.J., Hardy, J.P., Fitzhugh R.S., Tierney G.L. 2001. Colder soils in a warmer world: A snow manipulation study in a northern hardwood forest ecosystem. Biogeochemistry. 56: 135-150.

Henne, P.D., Hu, F.S., Cleland, D.T., 2007. Lake-effect snow as the dominant control of mesic-forest distribution in Michigan, USA. J. Ecology. 95 (3): 517-529.

Horsley, S.B,. Bailey, S.W, Ristau, T.E., Long, R.P., Hallett, R.A. 2008. Linking environmental gradients, species composition, and vegetation indicators of sugar maple health in the northeastern United States. Can. J. For. Res. 38: 1761-1774.

Horsley, S.B., Long, R.P., (Editors) 1999. Sugar maple ecology and health: An international symposium. Warren, MI. June 2-4, 1998. USDA Forest Service Gen. Tech. Rep. NE-26.

Hornbeck, J.W., Smith, R.B., Federer, C.A. 1988. Growth trends in 10 species of trees in New England, 1950-1980. Can. J. For. Res. 18: 1337-1340.

Houle, G. 1990. Growth patterns of sugar maple seedlings and mature trees in health and declining hardwoods stands. Can. J. For. Res. 20: 894-901.

Houston. D.R. 1981. Stress triggered tree diseases: the diebacks and declines. USDA For. Ser., Northeastern For. Exp. Station, Rep. NE=INF. 41-81. 36 p.

Houston, D.R. 1992. A host-saprogen model for forest dieback-decline diseases. P. 3-25 In Forest decline concepts. Manion, P.D., and D.Lachance (eds.). APS Press, New York.

Houston, D.R. 1999. History of sugar maple decline. In Horsley, S.B., Long, R.P., (eds.) 1999. Sugar maple ecology and health: An international symposium. Warren, MI. June 2-4, 1998. USDA Forest Service Gen. Tech. Rep. NE-26.

Huntington, T.G., Richardson, A.D., McGuire, K.J., Hayhoe, K. 2009. Climate and hydrological changes in the northeastern United States: recent trends and implications for forested and aquatic ecosystems. Can. J. For. Res. 39: 199-212.

Iverson, L.R. and Prasad, A.M., 2001. Potential changes in tree species richness and forest community types following climate change. Ecosystems 4(3): 186-199.

Jones, T.A., Thomas, S.C. 2004. The time course of diameter increment responses to selection harvests in Acer saccharum. Can. J. For. Res. 34: 1525-1533.

Kelley, R.S. 1988. The relationship of defoliators to recent hardwood dieback and decline in Vermont. Page 47 in: Proc. $21^{\text {st }}$. Ann. NE For. Insect Work Conference. A.G. Raske (compiler). Albany, NY.

Kolb, T.E., McCormick, L.H. 1993. Etiology of a sugar maple decline in four Pennsylvania stands. Can. J. For. Res. 23: 2395-2402.

Lane, C.J., Reed, D.D., Mroz, G.D., Liechty, H.O. 1993. Width of sugar maple (Acer saccharum) tree rings as affected by climate. Can. J. For. Res. 23: 2370-2375. 
Long, R.P., Horsley, S.B., Hallet, R.A., Bailey, S.W. 2009. Sugar maple growth in relation to nutrition and stress in the northeastern United States. Ecol. Appl. 19(6): 1454-1466.

Lorimer, C.G., Dahir, S.E., Singer, M.T. 1999. Frequency of partial and missing rings in Acer saccharum in relation to canopy position and growth rate. Plant Ecol. 143: 189202.

Lorimer, C.G. Frehlich, L.E. 1984. A simulation of equilibrium diameter distributions of sugar maple (Acer sacharrum) B. Torrey Bot. Club 111: 193-199.

McClenahen, J.R. 1995. Potential dendroecological approaches to understanding forest decline. In: Tree Rings as indicators of ecosystem health. Lewis, T.E., editor, 210 p. CRC Press, Boca Raton, FL

Malo, C., Messier, C. 2001. Impact of primary and secondary machinery tracks on fine root growth of sugar maple after selection cutting. Can. J. For. Res. 41: 892-897.

Manion, P.D. 1991. Tree disease concepts. Prentice-Hall, Englewood Cliffs, NJ.

Manion, P.D., Lachance, D., (eds) 1992. Forest Decline concepts. American Phytopathological Society, St. Paul, MN

Michigan Department of Natural Resources, 2002. 2002 Michigan Forest Health Highlights, Gerald Thiede, State Forester, Forest Health Protection Northeastern Area, USDA Forest Service, Updated February 2003. http://fhm.fs.fed.us/fhh/fhh02/mi/mi_02.htm.

Michigan Department of Natural Resources and Environment, 2009. Forest Management Division, 2009 Michigan Forest Health Highlights. http://fhm.fs.fed.us/fhh/fhh_09/mi_fhh_09.pdf

Michigan Department of Natural Resources and Environment, 2010. Forest Management Division, 2010 Michigan Forest Health Highlights. http://fhm.fs.fed.us/fhh/fhh_10/mi_fhh_10.pdf

Michigan Department of Natural Resources and Environment, 2012. Forest Management Division, 2012 Michigan Forest Health Highlights http://www.midnr.com/Publications/pdfs/ForestsLandWater/ForestHealth/FHH.pdf

Miller, D.E., Watmough, S.A. 2009. Air pollution, climate, soil acidity, and indicators of forest health in Ontario's sugar maple forests. Can. J. For. Res. 39: 2065-2079.

Millers, I., Shriner, D.S., Rizzo, D. 1989. History of hardwood decline in the Eastern United States. Gen. Tech. Rep. NE-126. Broomall, PA: U.S. Department of Agriculture, Forest Service, Northeastern Forest Experiment Station, 75 p.

National Oceanic Atmospheric Administration, National Climatic Data Center, Ashville, NC. http://www.ncdc.noaa.gov/ (accessed October 2012).

Payette, S., Fortin, M.J., Morneau, C. 1995. The recent sugar maple decline in southern Quebec: probable causes deduced from tree rings. Can. J. For. Res., 26: 1069- 1078.

Pilon, C.E., Côté, B., Fyles, J.W. 1994. Effect of snow removal on leaf water potential, soil moisture, leaf and soil nutrient status and leaf peroxidase activity of sugar maple. Plant Soil 162: 81-88.

Pilon, C.E., Côté, B., Fyles, J.W. 1996. Effect of an artificially induced drought and leaf peroxidase activity, mineral nutrition and growth of sugar maple. Plant Soil. 179: $151-158$. 
Ryan, D.J., Allen, O.B., McLaughlin, D.L., Gordon, A.M. 1994. Interpretation of sugar maple (Acer saccharum) ring chronologies from central and southern Ontario using a mixed linear model. Can. J. For. Res. 24: 568-575.

Schaberg, P.G., Hennon, P.E., D’Amore, D.V., Hawley, G.J., Borer, C.H. 2005. Seasonal differences in freezing tolerance of yellow-cedar and western hemlock trees at a site affected by yellow-cedar decline. Can J. For. Res. 35: 2065-2070.

Schmiege, D.C., Anderson, G.W. 1960. The forest insect and disease situation, Lake States, 1959. USDA For. Ser. Station Paper No 79.

Scott, R.W. and Huff, F.A., 1996. Impacts of the Great Lakes on regional climate conditions. J. Great Lakes Res. 22(4): 845-863.

St Clair, S., Sharpe, W. E., Lynch, J.P. 2008. Key interactions between nutrient limitation and climatic factors in temperate forests: a synthesis of the sugar maple literature. Can. J. For. Res. 38: 401-414.

Tierney, G.L., Fahey, T.J., Groffman, P.M., Hardy, J.P., Fitzhugh, R.D., Driscoll, C.D. 2001. Soil freezing alters fine root dynamic in a northern hardwood forest. Biogeochemistry 56: 175-190.

U.S. Department of Agriculture, Forest Service, 1964. The causes of maple blight in the Lake States. USDA Forest Service, Research Paper LS-10. Lake States Forest Experiment Station, St. Paul, MN. 15p.

U.S. Department of Agriculture, Forest Service, 1999. Forest Health Monitoring 1999 Field Methods Guide. USDA Forest Service, National Forest Health Monitoring Program, Research Triangle Park, NC, 1999.

U.S. Global Change Research Program, 2013. National Climate Assessment Development Advisory Committee, Draft Climate Assessment Report. January 2013. Washington DC. http://ncadac.globalchange.gov/ (accessed January 20, 2013)

Watmough, S., Brydges, T., Hutchison, T. 1999. The tree-ring chemistry of declining sugar maple in central Ontario, Canada. Ambio 28: 613-618. 
Table 2.1A. NOAA weather station information used in correlation with sugar maple tree growth analyses from the western Upper Great Lakes region. Stations were selected based on proximity to maple health evaluation plots and had at least 5-10 year's worth of data. Only years with all 12 months of recorded data are used in analysis.

\begin{tabular}{|c|c|c|c|c|c|c|}
\hline station name & state & $\begin{array}{l}\text { start } \\
\text { year }\end{array}$ & $\begin{array}{l}\text { end } \\
\text { year }\end{array}$ & $\begin{array}{c}\text { elevation } \\
(\mathrm{m}) \\
\end{array}$ & latitude & longitude \\
\hline Alberta Ford Center & MI & 1958 & 2011 & 399 & 46.644 & -88.481 \\
\hline Baraga & MI & 1950 & 2011 & 228 & 46.78906 & -88.51888 \\
\hline Beechwood 7 & MI & 1950 & 1989 & 506 & 46.18333 & -88.88333 \\
\hline Bergland Dam & MI & 1939 & 2011 & 397 & 46.58387 & -89.54962 \\
\hline Big Bay & MI & 1966 & 2011 & 204 & 46.80832 & -87.72286 \\
\hline Bucktabon & WI & 1946 & 2010 & 503 & 46.0183 & -89.31468 \\
\hline Champion Van Riper & MI & 1950 & 2007 & 479 & 46.51698 & -87.98363 \\
\hline Copper Harbor Ft Wilkins & MI & 1973 & 2011 & 190 & 47.4669 & -87.8681 \\
\hline Eagle Harbor Coast Guard & MI & 1949 & 1971 & 185 & 47.46239 & -88.16239 \\
\hline Eagle River & WI & 1948 & 2011 & 499 & 45.91086 & -89.26935 \\
\hline Flambeau Reservoir & WI & 1931 & 1980 & 476 & 46.06667 & -90.23333 \\
\hline Grand Marais & $\mathrm{MN}$ & 1931 & 2011 & 192 & 47.74169 & -90.34578 \\
\hline Hancock Airport & MI & 1953 & 2009 & 328 & 47.16694 & -88.49824 \\
\hline Herman & MI & 1969 & 2011 & 532 & 46.66512 & -88.34351 \\
\hline Ishpeming & MI & 1900 & 1986 & 439 & 46.48333 & -87.65 \\
\hline Kenton & MI & 1941 & 2001 & 357 & 46.48264 & -88.88402 \\
\hline Lac Vieux Desert & WI & 1946 & 2011 & 514 & 46.13008 & -89.13064 \\
\hline Long Lake Dam & WI & 1931 & 2000 & 497 & 45.89931 & -89.13366 \\
\hline Lutsen 3 & $\mathrm{MN}$ & 1987 & 2004 & 396 & 47.69988 & -90.6666 \\
\hline Minocqua & MI & 1931 & 2011 & 484 & 45.8817 & -89.73215 \\
\hline Munising & MI & 1912 & 2011 & 198 & 46.40685 & -86.65593 \\
\hline Ontonagon 6 & MI & 1978 & 2011 & 241 & 46.83346 & -89.201 \\
\hline Park Falls DNR HQ & WI & 1931 & 2011 & 467 & 45.9334 & -90.45014 \\
\hline Phelps & WI & 1931 & 2011 & 520 & 46.05331 & -89.04423 \\
\hline Sugar Camp & WI & 1946 & 2002 & 490 & 45.86643 & -89.3978 \\
\hline Watersmeet & MI & 1939 & 2011 & 491 & 46.28282 & -89.15844 \\
\hline Wolf Ridge & $\mathrm{MN}$ & 1994 & 2011 & 427 & 47.45 & -91.21667 \\
\hline
\end{tabular}


Table 2.1B. NOAA weather station information used in correlation with sugar maple tree growth analyses from the western Upper Great Lakes region. Stations were selected based on proximity to maple health evaluation plots and had at least 5-10 year's worth of data. Only years with all 12 months of recorded data are used in analysis.

\begin{tabular}{|c|c|c|c|c|c|c|}
\hline \multirow[b]{3}{*}{ station name } & \multirow[b]{3}{*}{ state } & \multicolumn{5}{|c|}{ average monthly } \\
\hline & & \multirow{2}{*}{$\begin{array}{c}\text { snowfall }^{*} \\
(\mathrm{~cm})\end{array}$} & \multirow{2}{*}{$\begin{array}{c}\text { precipitation } \\
(\mathrm{cm})\end{array}$} & \multicolumn{3}{|c|}{ temperature $\left(0^{\circ} \mathrm{C}\right)$} \\
\hline & & & & mean & $\min$. & $\max$. \\
\hline Alberta Ford Center & MI & 29.71 & 7.14 & 4.7 & -1.2 & 10.7 \\
\hline Baraga & MI & 24.73 & 7.26 & 4.6 & -2 & 11.2 \\
\hline Beechwood 7 & MI & 22.74 & 7.11 & 4.6 & -1.6 & 10.7 \\
\hline Bergland Dam & MI & 35.87 & 8.18 & 4 & -2.6 & 10.4 \\
\hline Big Bay & MI & 21.49 & 6.38 & 5.8 & 0.4 & 11.2 \\
\hline Bucktabon & WI & 11.67 & 6.53 & & & \\
\hline Champion Van Riper & MI & 25.76 & 7.04 & 4 & -2.9 & 10.9 \\
\hline Copper Harbor Ft Wilkins & MI & 21.81 & 6.35 & 5.8 & 1.4 & 10.2 \\
\hline Eagle Harbor Coast Guard & MI & 14.77 & 5.56 & 5.4 & 1.3 & 9.7 \\
\hline Eagle River & WI & 9.56 & 6.45 & 4.8 & -1 & 10.7 \\
\hline Flambeau Reservoir & WI & 13.08 & 6.88 & & & \\
\hline Grand Marais & $\mathrm{MN}$ & 10.78 & 5.44 & 3.9 & -0.8 & 8.7 \\
\hline Hancock Airport & MI & 42.93 & 6.68 & 4.6 & 0.2 & 9.1 \\
\hline Herman & MI & 49.14 & 8.15 & 4 & -1.9 & 9.8 \\
\hline Ishpeming & MI & 20.59 & 6.6 & 4.8 & -0.9 & 10.2 \\
\hline Kenton & MI & 15.29 & 6.22 & 5.6 & -1.7 & 12.5 \\
\hline Lac Vieux Desert & WI & 24.21 & 7.11 & & & \\
\hline Long Lake Dam & WI & 13.41 & 6.73 & 4.1 & -2.8 & 11.1 \\
\hline Lutsen 3 & $\mathrm{MN}$ & 17.76 & 7.06 & 2.8 & -2.5 & 8.1 \\
\hline Minocqua & MI & 18.74 & 6.63 & 4.4 & -1.9 & 10.9 \\
\hline Munising & MI & 24.52 & 7.39 & 5.2 & 0 & 10.3 \\
\hline Ontonagon 6 & MI & 39.83 & 7.04 & 6.1 & 0.2 & 11.9 \\
\hline Park Falls DNR HQ & WI & 10.43 & 6.86 & 5.2 & -0.6 & 10.8 \\
\hline Phelps & WI & 14.98 & 6.63 & & & \\
\hline Sugar Camp & WI & 12.04 & 6.48 & & & \\
\hline Watersmeet & MI & 17.51 & 6.99 & 4.4 & -2.1 & 10.6 \\
\hline Wolf Ridge & $\mathrm{MN}$ & 19 & 6.65 & 4.1 & -1.4 & 9.7 \\
\hline
\end{tabular}

Note: Temperature data not available from all stations.

*average monthly snowfall calculated from June-June to measure the winter season, rather than Jan-Dec. 
Table 2.3. Number of sugar maple trees that increased, decreased, or did not change in mean dieback from 2010-2012 in the western Upper Great Lakes region and proportion of trees that increased in dieback. Letters indicate significant differences between dieback \% category (chi-square test, $\alpha=0.05)$.

\begin{tabular}{cccc}
\hline $\begin{array}{c}\text { \% dieback } \\
(2010)\end{array}$ & $\begin{array}{c}\text { increased } \\
\text { dieback }\end{array}$ & $\begin{array}{c}\text { decreased dieback } \\
\text { or no change }\end{array}$ & $\begin{array}{c}\text { proportion of trees } \\
\text { increased dieback }\end{array}$ \\
\hline $75-99$ & 16 & 7 & $70 \mathrm{a}$ \\
$50-74$ & 2 & 24 & $38 \mathrm{~b}$ \\
$25-49$ & 36 & 93 & $28 \mathrm{bc}$ \\
$6-24$ & 312 & 558 & $36 \mathrm{c}$ \\
$1-5$ & 551 & 315 & $64 \mathrm{a}$ \\
\hline
\end{tabular}


Table 2.4. Proportion of sugar maple trees increasing or decreasing in 5, 10, and 20 year mean relative basal area increment in the western Great Lakes region ( $n=313$ trees) and the mean $\%$ decrease in BAI for trees that decreased for each relative year increment.

\begin{tabular}{cccc}
\hline & \multicolumn{2}{c}{ proportion of trees } & mean \% of BAI \\
mean relative BAI comparison & increase & decrease & decrease \\
\hline 2009-2004 : 2003-1998, 5 year & 57.2 & 42.8 & 14.5 \\
2009-2000:1999-1990, 10 year & 57.8 & 42.2 & 15.3 \\
2009-1990: 1989-1970, 20 year & 70.0 & 30.0 & 16.6 \\
\hline
\end{tabular}




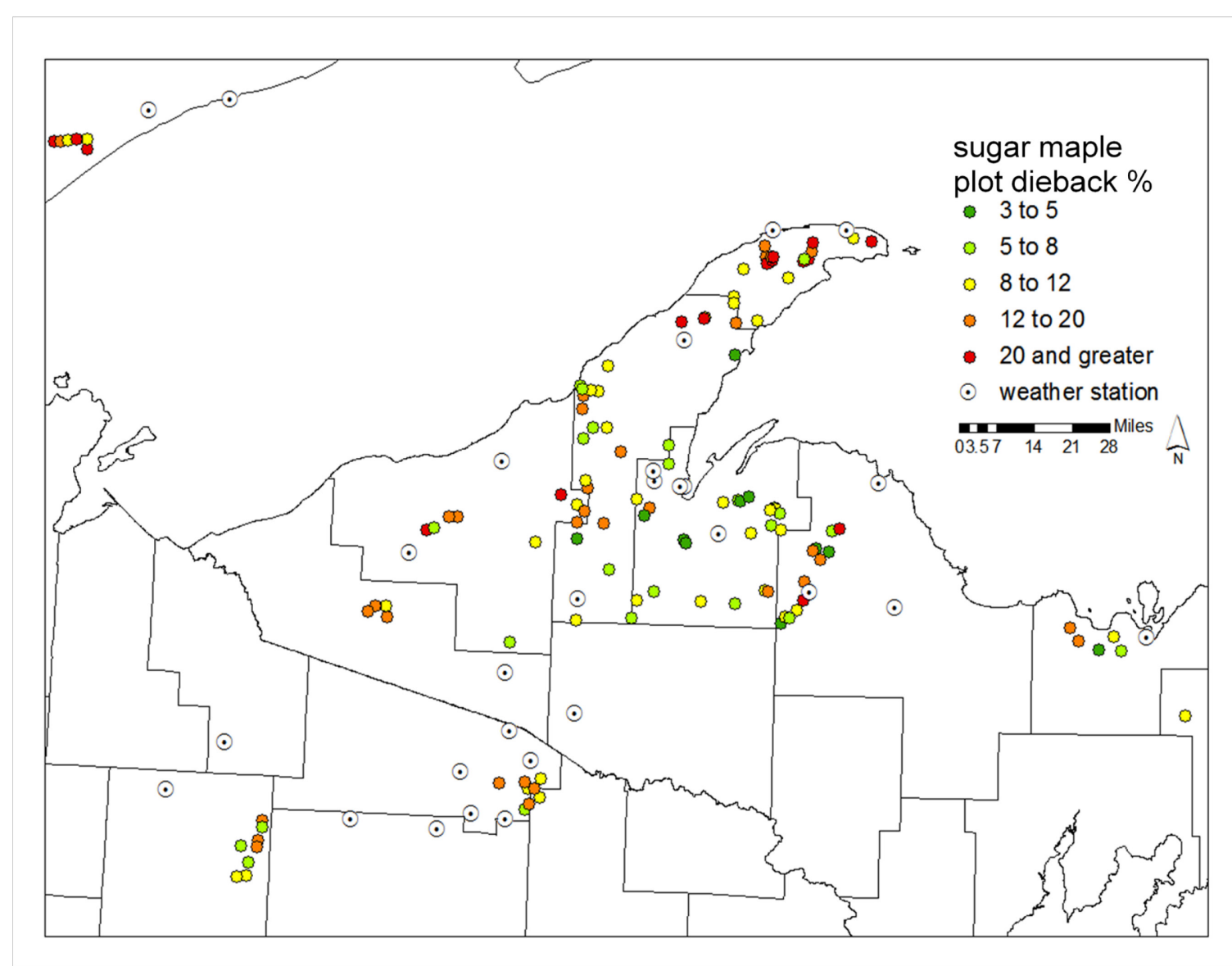

Figure 2.1. Sugar maple health assessment plot distribution across Upper Michigan, northern Wisconsin, and eastern Minnesota and mean plot sugar maple dieback from establishment year (2009-2010) to 2012 excluding initially dead trees. Data analyses were conducted with weather stations with 5-10 years of complete data availability. 


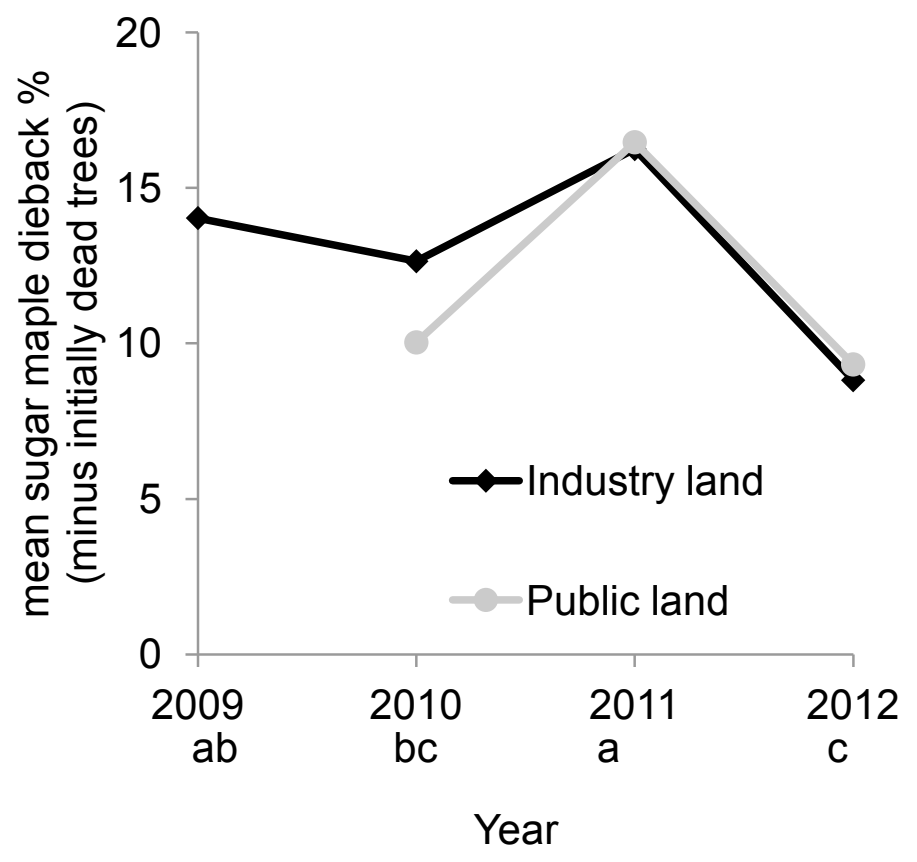

Figure 2.2. Mean sugar maple crown dieback percentage (excluding tree initially dead at start of study) from 2009-2012 on industry (61 plots) and public (59 plots) lands in the western Upper Great Lakes Region. Letters indicate significant differences between years of means independent of ownership. 


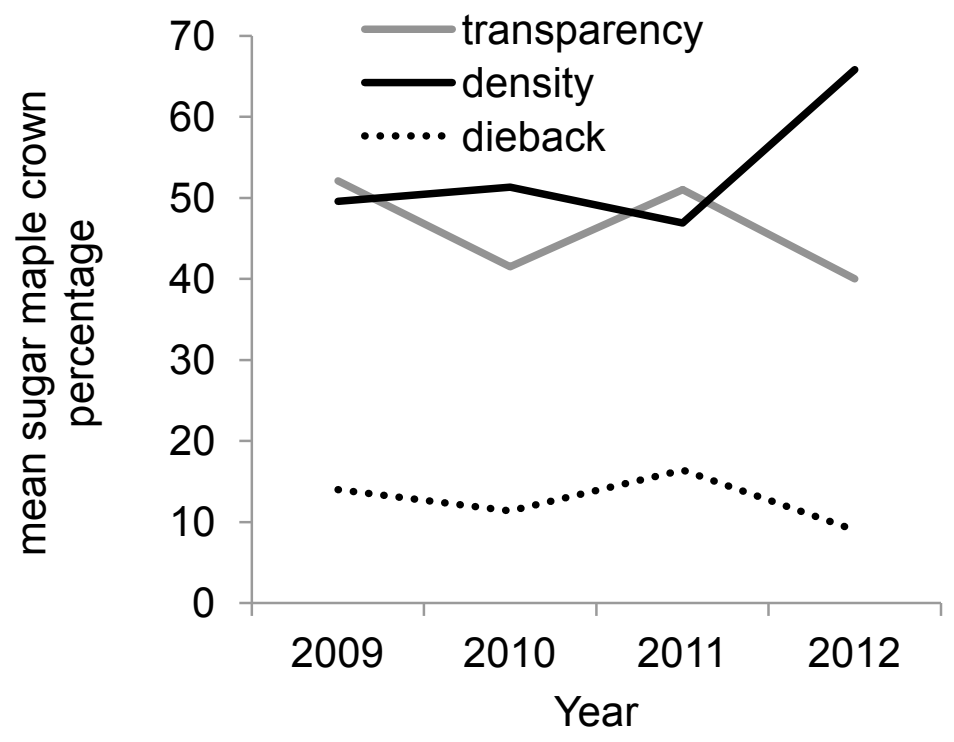

Figure 2.3. Mean sugar maple plot percentages of foliage transparency, crown density, and crown dieback during study period across the western Upper Great Lakes region. Note: transparency in 2012 from only a subset of plots. 

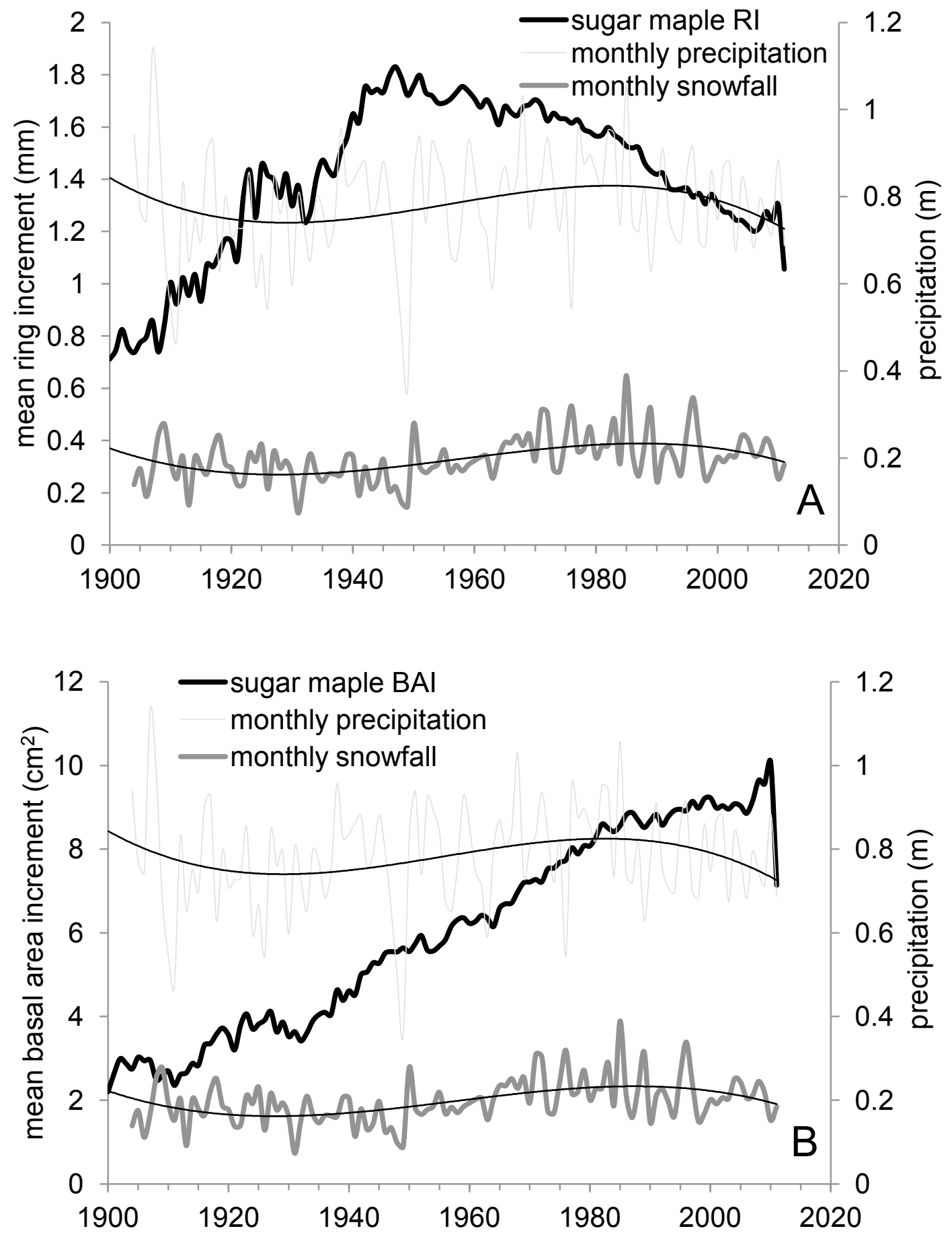

Figure 2.4. Pooled mean sugar maple $(n=313$ trees, mean dieback $=18.7 \%)$ annual ring width (RI) (A) and basal area increment (BAI) (B) with average total monthly snowfall and precipitation per year for weather station in the western Upper Great Lakes region. Climate data is fitted with a $3^{\text {rd }}$ order polynomial line indicating long term trend. 


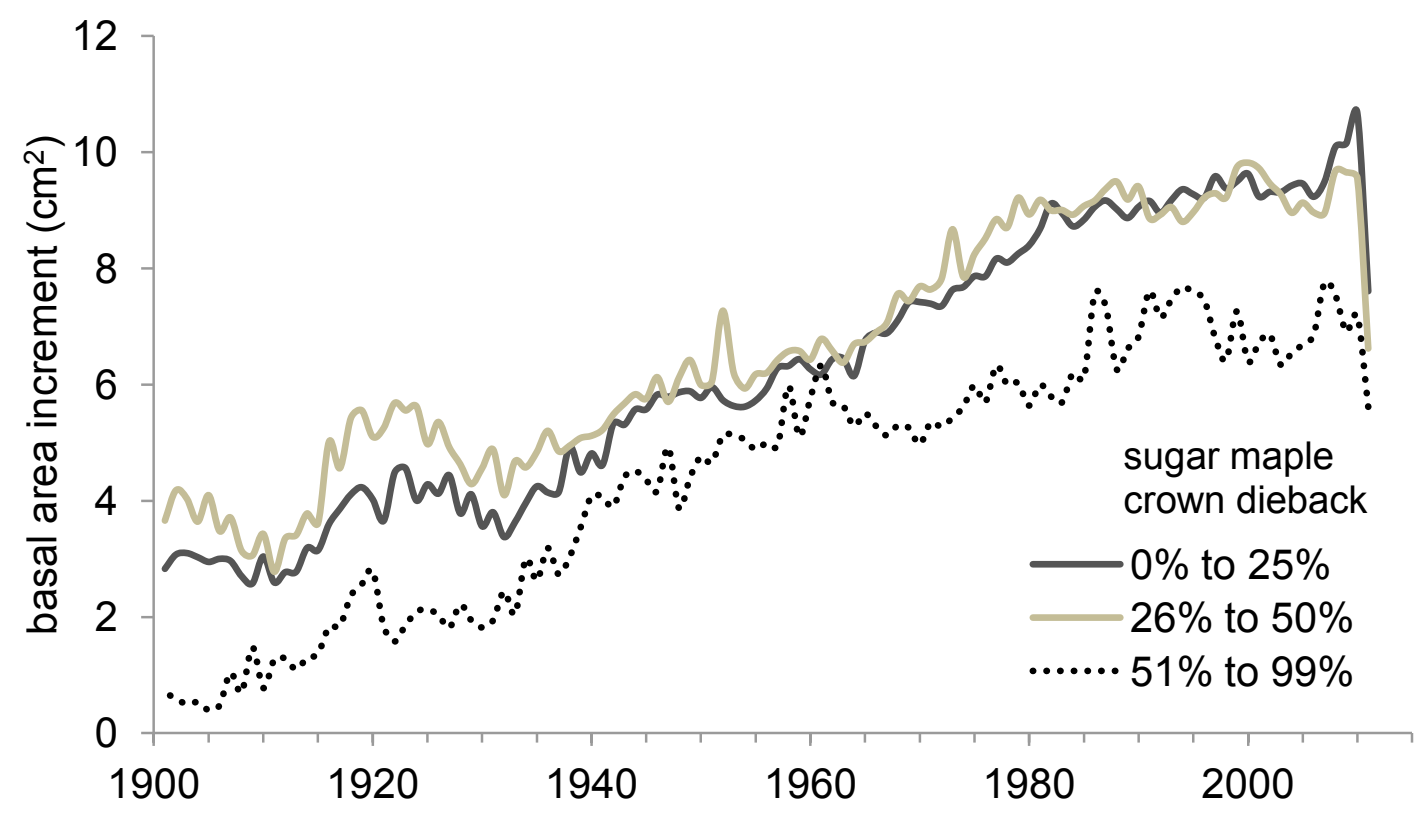

Figure 2.5. Mean sugar maple average basal area increment by percentage of crown dieback (during the year core was collected, 2009-2011) in the western Upper Great Lakes Region. 


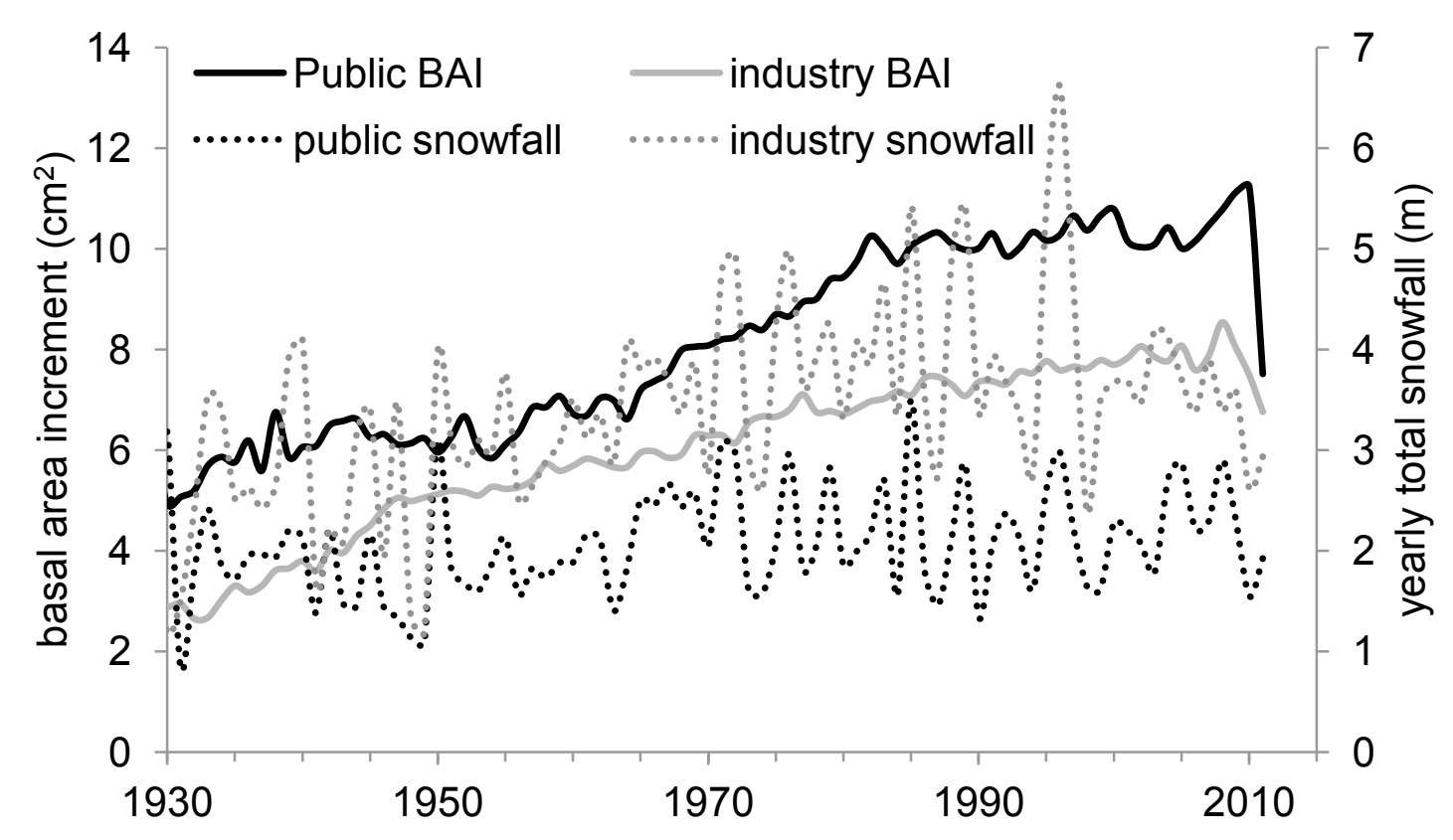

Figure 2.6. Mean sugar maple basal area increment (BAI) and average yearly total snowfall stratified by ownership (industry and public) in the western Upper Great Lakes region. Industry lands are located primarily in Keweenaw, Houghton, Baraga, and Marquette counties MI, while public lands in the surrounding region include eastern and southern Upper MI, northern WI, and eastern MN. Weather stations data are separated by proximity to plot locations. 


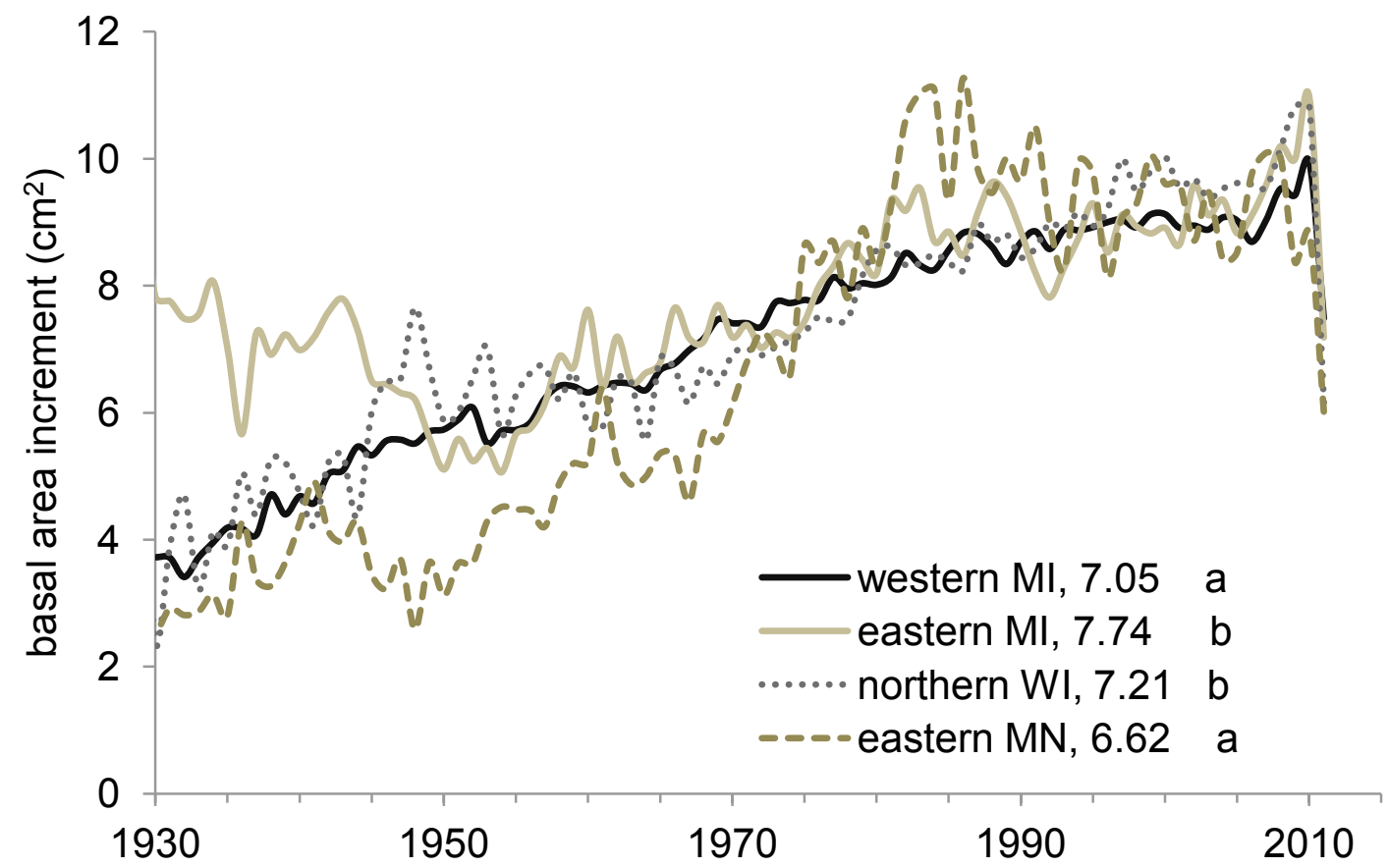

Figure 2.7. Mean sugar maple basal area increment by regional area; western and eastern Upper Michigan, northern Wisconsin, and eastern Minnesota $(\mathrm{n}=236,19,43,16$ trees respectively). Numbers indicate mean BAI from and letters indicate significant differences $(\mathrm{p}<0.05)$ in mean BAI chronologies from 1930-2011. 

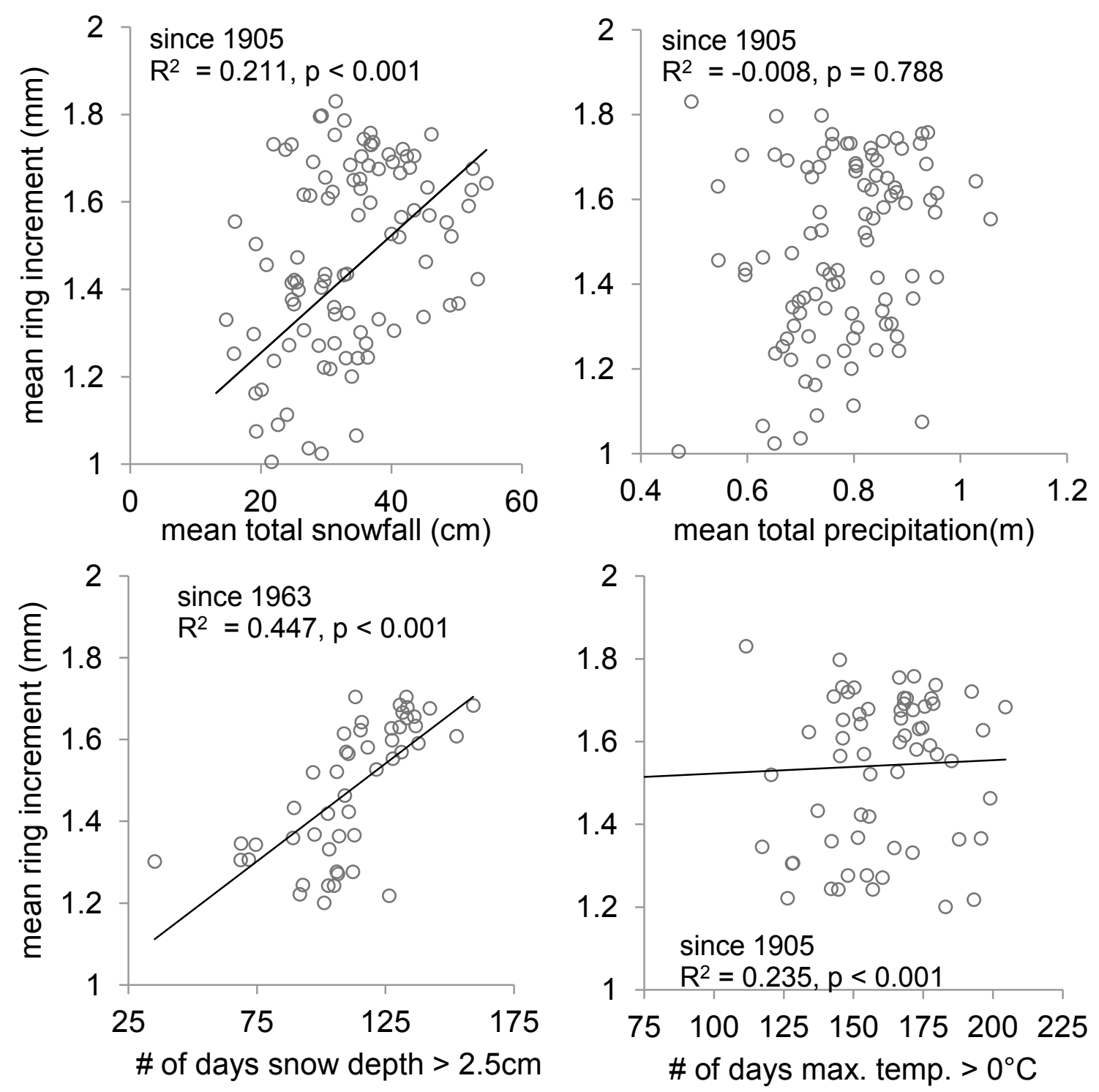

Figure 2.8. Linear relationships between mean sugar maple ring increment (RI) from year indicated to 2011 across the western Upper Great Lakes region and climate variables, including the average total yearly precipitation, total snow fall, number of days with a maximum temperature below freezing and number of days with snow depth greater than $2.5 \mathrm{~cm}$. 

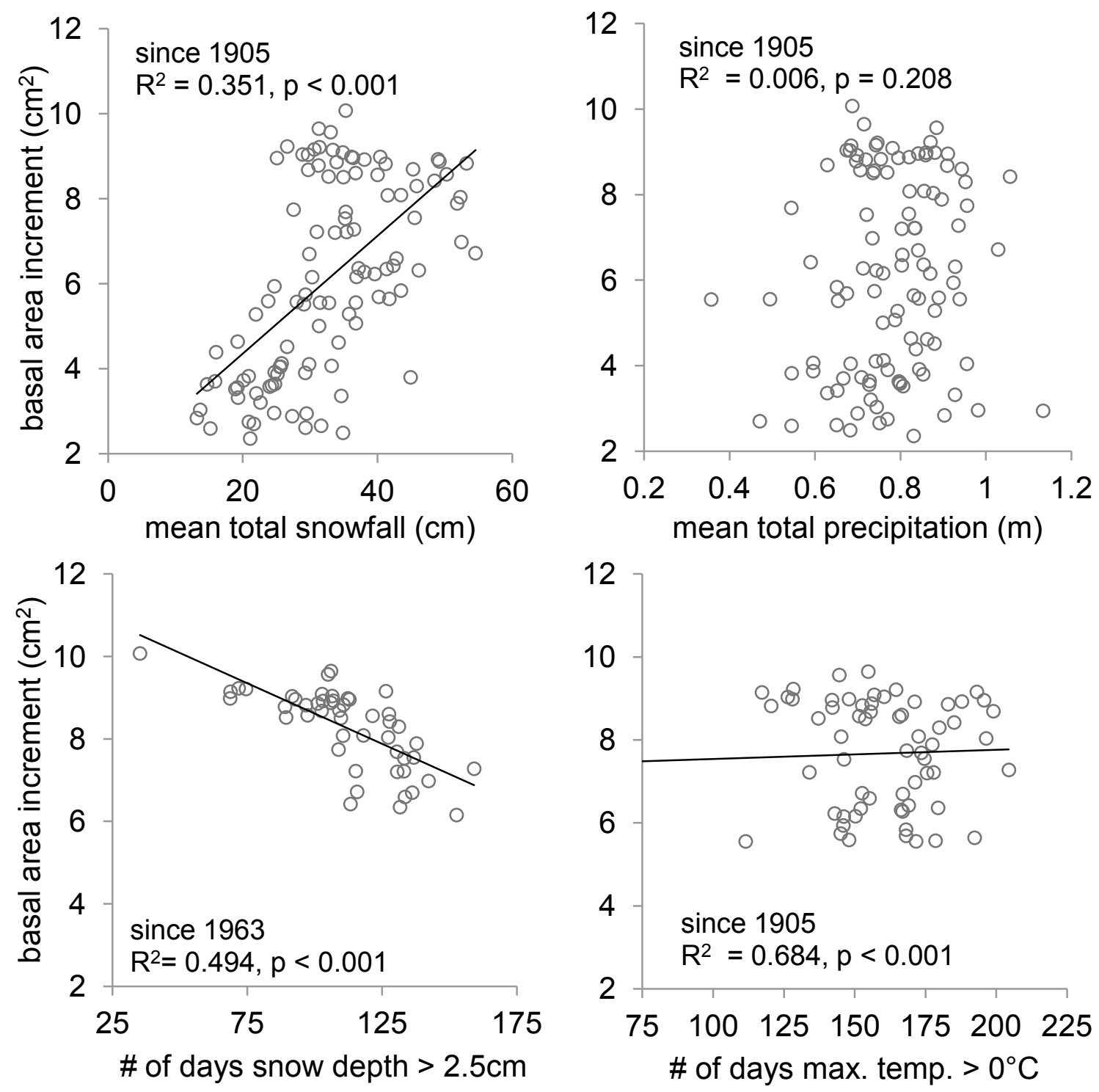

Figure 2.9. Linear relationships between mean sugar maple basal area increment (BAI) from year indicated to 2011 across the western Upper Great Lakes region and climate variables, including average total yearly precipitation, total snow fall, number of days with a maximum temperature below freezing and number of days with snow depth greater than $2.5 \mathrm{~cm}$. 

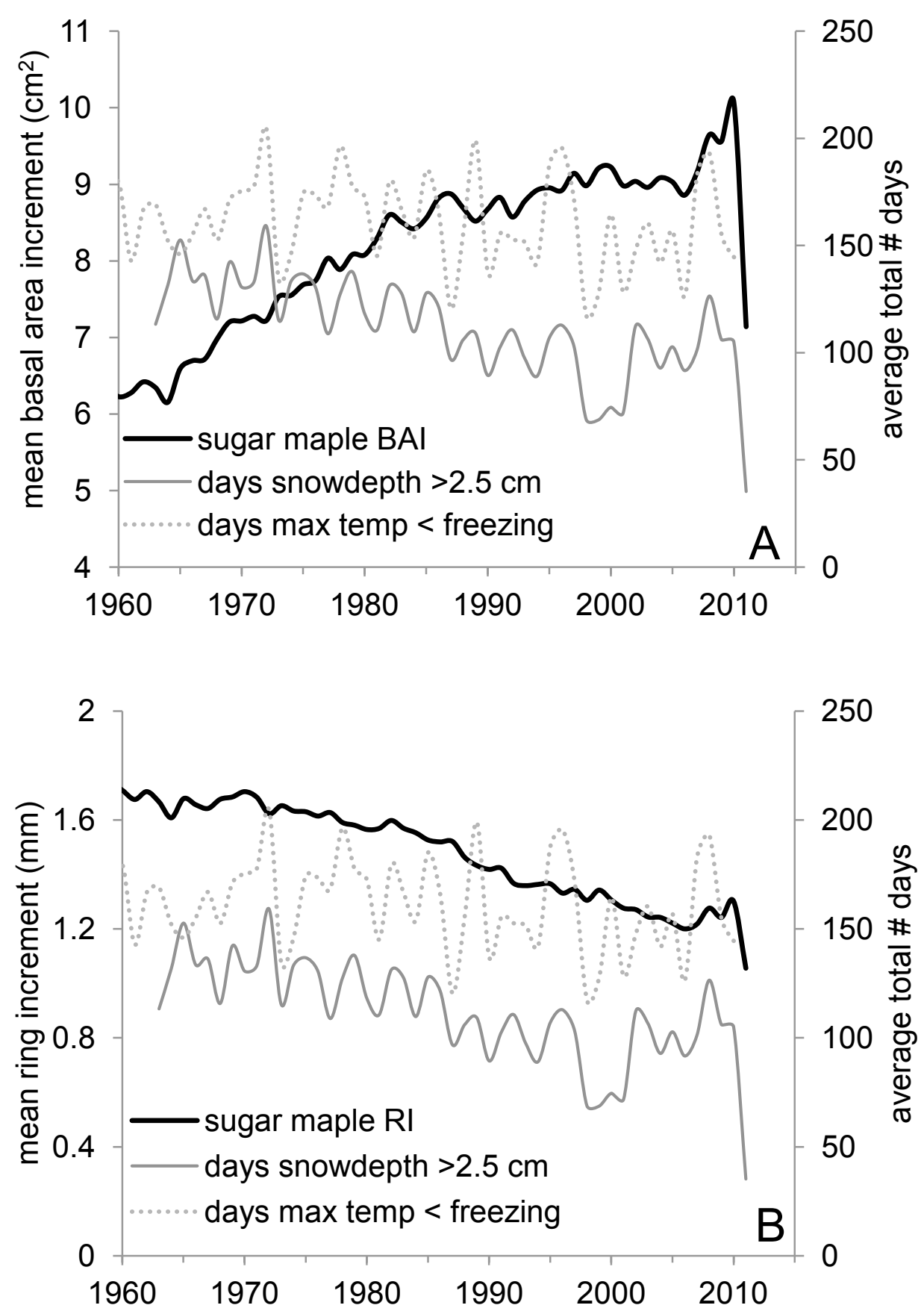

Figure 2.10. Mean sugar maple ( $\mathrm{n}=313$ trees) basal area increment (BAI) (A) and ring increment (RI) (B) compared to average total days in a year with snow depth greater than $2.5 \mathrm{~cm}$ and average total days in a year with max. temperature less than or equal to freezing $\left(0^{\circ} \mathrm{C}\right)$ at weather stations across the western Upper Great Lakes region. 


\title{
Chapter 3
}

\section{Importance of Forest Floor Perturbation Resulting from Exotic Earthworm Activity to Sugar Maple Dieback in the Upper Great Lakes Region ${ }^{2}$}

\begin{abstract}
Sugar maple (Acer sacharrum Marsh.) in the western Upper Great Lakes region has recently been reported with increased crown dieback symptoms, prompting investigation of the dieback etiology across the region. Evaluation of sugar maple dieback from 2009-2012 across a 120 plot network in Upper Michigan, northern Wisconsin, and eastern Minnesota determined that high levels of non-native invasive earthworms impacting the forest floor was significantly related to mean maple dieback. Other variables tested (including basic plot information, tree conditions, sampled soil nutrients, and soil survey information) determined significant relationships between dieback and increased soil $\mathrm{C}$ and decreased soil $\mathrm{Mn}$ and reduced herbaceous aerial cover, all of which may be correlated to earthworm activity. Relationships between recent and long term growth trends were also examined. Plots with the most visible earthworm impacts on the forest floor, highest soil $\mathrm{pH}$, lowest soil Mn content, and highest total soil $\mathrm{C}$ have also had a significantly lower sugar maple basal area increment chronology since at least the 1950's possibly suggesting historic earthworm presence at many plot locations. This study presents significant evidence correlating sugar maple dieback in the western Great Lakes Region with earthworm impacts and highlights the need for considering non-native earthworm impacts when determining factors influencing sugar maple health.
\end{abstract}

2

The material in this chapter is planned for submission in the near future and is formatted as such. 


\section{Introduction}

Declines in the health of sugar maple (Acer saccharum Marsh.) have been documented and examined across the northeastern United States throughout the range of sugar maple especially in the last 50 to 60 years (Kessler, 1965; Mader and Thompson, 1969; McLaughlin et al., 1987; Millers et al., 1989; Kolb and McCormick, 1993; Horsley and Long, 1999; Drohan et al., 2002). During periods of dieback and decline episodes, the relationships between stand level measurements, management history, defoliator outbreaks, climate, and nutrient status have been examined (Allen et al., 1992; Houston, 1992; Manion and Lachance, 1992; St. Clair et al., 2008). Studies on sugar maple dieback have focused on stands in the northeastern portion of the range of sugar maple, including New England and Canada, with fewer studies located in the Midwestern United States. Sugar maple health in the eastern part of its range appears to be driven by local conditions, mainly predisposed by soil nutrients and incited by heavy defoliation, severe drought, or a decade of bad winters (Horsley and Long, 1999).

In the Great Lakes Region, the largest reported dieback and decline was during the late 1950's to early 1960's with high water tables and heavy cutting implicated at the time (Millers et al., 1989). Subsequent reports found dieback in drier sites and undisturbed areas as well but were not further examined (Anderson and Schmiege, 1959). In northern Wisconsin and southern Upper Michigan pockets of severe dieback and mortality were reported in the late 1950's and termed 'maple blight'. The 'blight' began to subside after 1958 with heavy defoliation by maple webworm (Tetralopha asperatella Clemens) and early frosts being implicated (Anderson and Schmiege, 1959; Schmiege and Anderson, 1960).

Anecdotal observations in some sugar maple stands have reported a patchy differences in the sugar maple forest floor condition across the study area. Non-native earthworms are currently invading and spreading throughout the upper midwest; however their species distribution and impacts vary across the region (Sackett et al., 2012; Shartell et al., 2012). Earthworm presence in the forest alters the forest floor, soil and understory biota and soil physical and chemical characteristics especially in the upper soil horizons and forest floor (Groffman et al., 2004; Hale et al., 2005; Hale et al., 2006; Hale et al., 
2008). Recent research has attributed earthworm invasion to sugar maple growth rate disturbances (Larson et al., 2010) but little else is known about the impact of earthworms on sugar maple health.

Severe dieback of sugar maple has been reported in the western Upper Peninsula of Michigan and other areas in the North Central region in recent years (MDNR 2009, 2010, 2012). In some areas, high proportions of crop trees are being affected, increasing concern. The extent to which the current dieback is related to biotic or abiotic factors is unclear. The objective of the work presented is to determine the etiology of the current sugar maple dieback by characterizing relationships among canopy health and biotic and abiotic stand variables in the western Upper Great Lakes Region. Relationships between current dieback levels, recent growth, and seedling regeneration were investigated along with baseline forest plot information, tree condition, soil characteristics and nutrients, and forest floor condition to assess factors that may be related to the observed decreasing canopy condition.

\section{Methods}

\subsection{Plot Establishment and Base Measurements}

A network of 120 forest evaluation plots were established on private industry land in the western Upper Peninsula in 2009 (Marquette, Baraga, Houghton, and Keweenaw Counties) and public lands in northern Wisconsin, eastern Minnesota, and Upper Michigan in 2010 (Figure 3.1). Regional foresters were consulted to identify areas of northern hardwoods with and without significant levels of sugar maple dieback. Most of the circular, 0.04 ha plots included at least 10 sugar maple trees and were at least $40 \mathrm{~m}$ from established roadways to minimize edge effects. All species greater than $10 \mathrm{~cm}$ within the plots were measured (diameter breast height, dbh), and underwent full canopy and bole assessments, including crown dieback following standard Forest Health Monitoring Protocol (USDA, 1999). All plots were reevaluated during subsequent years until 2012 with trees that had grown large enough tagged and added into the plot measurements.

Crown dieback was estimated as the percentage of the whole crown that has 
dieback (0-99\%), including recently dead branches, peeling branches or bark, or fines without buds. In calculating average sugar maple dieback for plots in each year, trees that were harvested were no longer included. Trees that were 100\% dead during the plot establishment year were noted but not included in the plot average dieback for that year; however, subsequent natural mortality was included to capture dead and dying trees.

Damage to trees caused by cankers, sugar maple borer (Glycobius speciosus (Say)), visible decay, woodpeckering, or other causes were recorded. The size and apparent cause of wounds was estimated (logging or otherwise). Management history records of the last year harvested were obtained where available.

Elevation, slope, aspect, and landscape position ( $5=$ shoulder or summit, midslope, bench, lower slope, bottomland, or flat) was recorded. Other baseline plot information was recorded ten paces from center in the four cardinal directions to provide a plot average. Soil density was measured with a Dickey soil penetrometer at approximately every $7.5 \mathrm{~cm}$ until $45 \mathrm{~cm}$ or rock. Percent aerial cover of herbaceous plants was assessed by species in one $\mathrm{m}^{2}$ quadrats using visual estimation (Coffman et al., 1984). The forest floor condition or earthworm impact rating was determined using a 1-5 scale (Table 3.1) similar to that used by the Great Lakes Worm Watch, (greatlakeswormwatch.org) (Hale 2007; Loss et al., 2013). The earthworm impact rating scale quantifies the condition of the forest floor in a one $\mathrm{m}^{2}$ quadrat with 1 having multiple middens and castings present with only the most recent litter on the forest floor and 5 being no evidence of earthworms and a completely intact forest floor (Shartell et al., 2013). Five paces from center in the four cardinal directions, a $3.6 \mathrm{~m}$ radius sapling $(1.27-9.9 \mathrm{~cm} \mathrm{dbh})$ plot and a $1.12 \mathrm{~m}$ radius seedling regeneration plot were assessed and all species of seedlings $(<1.27 \mathrm{~cm}$ dbh) were counted.

\subsection{Tree Cores}

Each year of plot evaluation, a subset of plots had increment cores collected. At each plot, three trees in a similar size class (ideally within $5 \mathrm{~cm} \mathrm{dbh}$ ) were sampled. These trees included one with little to no dieback, one with intermediate dieback for the plot, and one with relatively high or the highest dieback for the plot. All cores were from 
dominant or co-dominant canopy trees to reduce the likelihood of partial or missing rings (Lorimer et al., 1999).

For each of the three trees that were cored in each plot, two increment cores were collected at 90 degree angles at breast height $(1.4 \mathrm{~m})$ for determination of the annual diameter increment. Cores were refrigerated until being mounted and sanded for reading annual ring widths on a digital measuring stage to the nearest $0.001 \mathrm{~mm}$ with Measure J2X software (Voor-Tech Consulting LLC, Nolderness, NH, 1999). Cores were visually cross dated and cores with significant decay or that were otherwise unreadable were excluded. Data from the two cores from each tree were averaged per year per tree. Growth chronologies were constructed as annual basal area increment (BAI) $\left(\mathrm{cm}^{2}\right)$ using the following equation where $\mathrm{R}$ is the tree radius at $\mathrm{dbh}(\mathrm{cm})$ and $t$ is the year of tree ring formation: $\mathrm{BAI}_{\mathrm{t}}=\pi\left(\mathrm{R}_{t}{ }_{t}-\mathrm{R}_{t-1}^{2}\right)$. Recent mean radial increments (RMRI) were calculated as the most complete, recent 5 year (2003-2008) mean radial increment (mm) per tree.

\subsection{Soil Sampling}

A minimum of four, 2-cm diameter soil samples for a plot average were collected to a $30 \mathrm{~cm}$ depth approximately $3 \mathrm{~m}$ from plot center in the four cardinal directions during August. Soil samples were oven dried at $50^{\circ} \mathrm{C}$ and sieved $(2 \mathrm{~mm})$ prior to analysis. To determine $\mathrm{pH}$, samples were measured 1:1 ratio with deionized water after standing at room temperature for 15 minutes with a $\mathrm{pH}$ meter (Digi-Sense, $\mathrm{pH} / \mathrm{mV} / \mathrm{ORP}$ 5938-00). Particle size analysis was done using the hydrometer method with $100 \mathrm{~g}$ of soil and $10 \mathrm{ml}$ of sodium hexametaphosphate solution in a cylinder to estimate the percent of sand, silt and clay particles in solution. Combustible organic matter was measured using loss on ignition (LOI) determined by placing $10 \mathrm{~g}$ samples of each of sample into a muffle oven furnace at $290^{\circ} \mathrm{C}$ for 4 hours and immediately reweighing.

Soil samples were also collected with a $2.5 \mathrm{~cm}$ diameter soil corer from beneath the drip lines of two of the three trees with dieback that were also cored, the trees with the least and the most relative dieback. Under each tree sampled, five $20 \mathrm{~cm}$ deep cores were pooled together but separated by horizon. Soils were analyzed for exchangeable 
cations, extractable trace elements, and extractable $\mathrm{SO}_{4}-\mathrm{S}$ using ICP, with $1 \mathrm{M} \mathrm{NH}_{4} \mathrm{Cl}$ digests. A 1:10 extraction ratio was used (0.5 g in $25 \mathrm{~mL}$ of extractant). Extracts were diluted 1:10 in deionized water to prepare a better background matrix for ICP analysis. Soil nutrient levels used in the regression analysis here included average plot values of soil C, N, K, Ca, Mg, Al, Na, Ca/Al, Mn, Fe, Ni, Cu, Zn, Cd, Pb, Cr, B, Sr, Ba, $\mathrm{SO}_{4}-\mathrm{S}$, $\mathrm{C} / \mathrm{N}$ ratio, $\mathrm{Ca} / \mathrm{Al}$ ratio, and exchangeable cation capacity (ECEC) (see Chapter 4 for total soil nutrient values). Soil nutrient concentrations are not weighted by proportion of the sample horizon size. Other soil measurements included in the regression analysis included $\mathrm{pH}, \%$ sand, $\%$ silt, $\%$ clay, and $\%$ organic matter (LOI).

The regression models also included soil series information from Soil Survey Geographic Online Database (Minnesota plots not available) including soil order, great group, the steepest slope in the series, drainage class (poorly drained, moderately well

drained, well drained, somewhat excessively drained), presence of saturated conditions in subgroup, oxides in subgroup, presence of fragipan, dominant particle size (fine, loam, sand), shallowest depth to bedrock ( $\mathrm{cm})$, depth to high water table $(\mathrm{m})$, surface run off class (rapid, high, medium, slow, low), potential for frost action (high, moderate, low), potential for seedling mortality, (high, moderate, low), sugar maple site index, and drainage index from the U.S. Forest Service National Drainage Index (http://foresthealth.fs.usda.gov/soils/, accessed 12-1-12).

\subsection{Statistical Analysis}

Mean sugar maple dieback (2009-1012) was evaluated using unweighted stepwise linear regression with non-forced variables $(\alpha=0.05$ or 0.1 for approaching significance) and Pearson correlation coefficients. For regression purposes, the individual tree percentages of crown dieback were averaged for each plot and trees that were $100 \%$ dead the initial year of data collection were excluded. Subsequent mortality was captured by inclusion in the plot average unless trees were harvested and removed from the dataset. Plot averages were not transformed as the mean and the variances were independent (Allen et al., 1992). Models were tested with measured plot level variables and with plot level variables plus all soil variables. Soil variables were added to the models to test the 
robustness of plot level characteristics impacts on dieback- The significance of earthworm impacts in the first model prompted the consideration of soil factors that may be determining earthworm presence. As earthworm impacts were significant in both of these regression analyses, relationships among earthworm impacts and other significant plot variables, such as recent growth (RMRI), were investigated further using linear regression. A repeated measures analysis of variance and Tukey's procedure for pairwise comparisons was used to evaluate the mean BAI chronologies with varying earthworm impact levels and other factors significant in the regression models. All analyses were conducted with the software program Statistix 9.1 (C1985-2008).

\section{Results}

Descriptors of plot characteristics are located in Table 3.2. The stepwise regression of plot characteristics with the total average sugar maple dieback (2009-2012) retained only one variable in the model: average earthworm impact rating $(\mathrm{p}=0.014)$ (Table 3.3). Other factors approaching significant correlation $(\alpha=0.1)$ with sugar maple dieback include the percent of total canopy cover $(\mathrm{p}=0.058)$, the percent of trees with wounds (including logging wounds, seams, and other bole damage not including obvious cankers $)(p=0.054)$, and percent with cankers (Nectria and Eutypella spp.) $(\mathrm{p}=0.097)$.

The stepwise regression model of sugar maple dieback was also run with all plot characteristics and edaphic factors (Table 3.4) including soil taxonomy, physical variables, and nutrient levels. Four variables were retained: earthworm impact rating ( $\mathrm{p}=$ 0.009), soil Mn, soil $\mathrm{C}$, and herbaceous cover (all $\mathrm{p}<0.001$ ).

Average plot seedling counts were significantly correlated with average sugar maple dbh $(r=0.395 ; p=0.006)$ and the seedling mortality factor from Soil Surveys $(r=$ $0.103 ; \mathrm{p}=0.016$ ), but no other variables, including dieback. No factors in the model with seedling counts were significant with $\alpha=0.1$.

Though average mineral soil $\mathrm{pH}$ was not significantly related to sugar maple crown dieback in either of the regression models, soil $\mathrm{pH}$ was significantly related to the average earthworm impact rating ( $\mathrm{p}<0.001$; Figure 3.2). As dieback increased, average soil $\mathrm{pH}$ was less acidic. The RMRI also significantly decreased with increasing soil $\mathrm{pH}$ 
( $p=0.006$; Figure 3.2). Examining other significant variables associated with dieback, the RMRI was not significantly correlated with soil $\mathrm{C}(\mathrm{p}=0.138)$, however recent growth did significantly increase with increasing soil $\mathrm{Mn}(\mathrm{r}=0.305 ; \mathrm{p}<0.001)$. The RMRI also significantly increased with increased herbaceous aerial cover $(r=0.011 ; p<0.001)$

The stepwise regression of plot characteristics with the RMRI (2003-2008) retained only one significant variable; the distance to Lake Superior $(r=0.19 ; \mathrm{p}=0.039)$. Factors approaching significance $(p=0.1)$ included herbaceous aerial cover $(r=-0.415 ; p$ $=0.061)$. The regression model for RMRI including all plot and soil characteristics retained four significant variables: $\mathrm{dbh}(\mathrm{r}=0.275 ; \mathrm{p}<0.001)$, elevation $(\mathrm{r}=0.189 ; \mathrm{p}<$ $0.001)$, soil $\mathrm{Pb}(\mathrm{r}=0.198 ; \mathrm{p}<0.001)$, and plot slope $(\mathrm{r}=0.245 ; \mathrm{p}=0.008)$. Variables in the model with a significant factor $(\alpha=0.1)$ were soil $\mathrm{pH}(\mathrm{r}=0.057 ; \mathrm{p}=0.059)$, soil $\mathrm{Cu}$ $(\mathrm{r}=0.112 ; \mathrm{p}=0.089)$, and soil $\mathrm{Zn}(\mathrm{r}=0.099 ; \mathrm{p}=0.091)$.

The annual sugar maple BAI chronologies were significantly different $(\mathrm{p}<0.001)$ across the range of earthworm impact ratings (Figure 3.3). Trees in plots with the most evidence of earthworms had significantly lower annual BAI since at least the 1950s than plots with less evidence of earthworms. Stratifying the nutrient factors significantly correlated with dieback in the initial stepwise regression models (soil Mn, soil C) and soil $\mathrm{pH}$ also indicated significant differences ( $\mathrm{p}<0.001$ for each) between mean BAI chronologies (Figure 3.3, 3.4).

\section{Discussion}

This study presents significant evidence correlating sugar maple dieback in the western Great Lakes Region with earthworm impacts. Evidence of earthworm activity and variables that are influenced by earthworm activity (such as herbaceous diversity and abundance and soil chemistry) were significant in models of dieback and recent growth. Recent research has indicated unexpected, widespread decline in tree growth in northern North American, despite increased warming and $\mathrm{CO}_{2}$ (Silva et al., 2010). Invasive, exotic earthworms are an additional stress impacting tree species in this region that necessitates closer examination. 
Areas with the greatest visible impact on the forest floor from earthworm presence appear to be located around Houghton and Keweenaw County (Figure 3.5) with some of the largest and longest European settlement history in the Upper Peninsula, MI (Stearns, 1997). Earthworm activity causes soils to not only be more intermixed, but have higher organic content (increased C), increased bulk density, and warmer, drier conditions as the forest litter layer is consumed and pulled down (Groffman et al., 2004; Hale et al., 2005; Hale et al., 2006; Hale et al., 2008). Maple dieback was positively correlated with soil C, reflective of increased earthworm activity (Wironen and Moore, 2006). By the end of one season, as much as $87-98 \%$ of sugar maple leaf litter mass can be lost in mesocosms with Lumbricus terrestris and other worm species present (Holdsworth et al., 2012). Furthermore, maple is one of the northern hardwood species with relatively higher foliage calcium content (as opposed to oak and beech). Lumbricid earthworms preferentially feed on higher quality litter and therefore may have greater impacts on invaded maple stands compared to other northern hardwood stands (Holdsworth et al., 2012). Maple roots may be very sensitive to changes in soil conditions, as the majority of maple fine roots are located in the $\mathrm{O}$ horizon and upper 10 cm of soil (Fisk et al., 2004). Mycorrhizal colonization in maple roots have also been shown to decrease due to worm activity (Lawrence et al., 2001; Dempsey et al., 2011). Earthworms have also been correlated with reduced incremental basal growth following invasion and increasing tree sensitivity to drought (Larson et al., 2010).

Earthworms are calciferous organisms and tend to avoid more acid soils (Reich et al., 2005, Shartell et al., 2013). Increased evidence of earthworms was found on more alkaline soils (Figure 3.2). The dieback models and BAI chronologies also indicated a significant negative relationship with soil $\mathrm{Mn}$, which is to be expected as there was less evidence of earthworm activity in the more acidic soils with greater Mn availability. Earthworm activity may create a "pulse" or short term increase in nutrients (Hale et al., 2008; Larson et al., 2010) that rapidly leach out or are fixed by the correspondingly increased oxides in soil. This pattern is likely why earthworm garden experiments often report increases in soil nutrients (Hale et al., 2008) contradictory to field observations.

Biotic soil disturbance (mainly by earthworms) likely has occurred in other areas 
but the impacts by these organisms are usually not the study focus. In the Quebec Appalachians, sugar maple stands with less acidic, more intermixed soils had significant amounts of $\mathrm{Fe}$ and $\mathrm{Al}$ present where fine roots are in the upper soil layers and displayed symptoms of $\mathrm{P}$ deficiencies (Pare and Bernier, 1989). The Fe and Al oxides rapidly fix nutrients and act as a sink, limiting plant uptake (Pare and Bernier, 1989; Casson et al., 2012). Similar findings of higher mineral availability but less uptake in more acidic soils have been reported in New England and Europe (SanClements et al., 2010). For other metals tightly bound to organic matter $(\mathrm{Zn}, \mathrm{Cu}, \mathrm{Pb})$, the rapid decomposition of the forest floor would increase metal content in the mineral soil (Watmough et al., 2004).

As percent canopy dieback increases, canopy cover decreases and it is reasonable that increased wounds and bole damage would increase the amount of dieback symptoms. Wounds and damage may be even more important on acidic sites with relatively low $\mathrm{Ca}$ and high $\mathrm{Al}$, as $\mathrm{Ca}$ has been shown to play an important role in wound closure (Huggett et al., 2007). Wounds also act as an entry court for decay fungi (Ohman 1970; Boddy and Rayner, 2006). Sampling for the sugar maple sapstreak fungus, (Ceratocystis virescens (Davidson) Moreau), determined 8\% of maples in U.P., MI plots to be infected, but did not correlate sapstreak presence with crown condition (Bal et al., 2013).

Earthworm activity has previously been shown to be related to seedling counts (Hale et al., 2006; Corio et al., 2009), but this effect was not evident in this study. This could be a result of assessing forest floor condition rather than measuring specific earthworm biomass or species assemblages as was done in other studies.

The negative relationship between crown dieback and the presence of cankers may be explained by management. Many management plans in northern hardwoods call to remove trees with cankers as they are less likely to increase profit in the next harvest cycle. Therefore, stands that have been entered in the last decade likely have less standing trees with large obvious cankers.

The RMRI increased as distance to Lake Superior increased, probably reflective of changing climate conditions across the region and increased amount of earthworm detection in the Keweenaw Peninsula, MI compared to other areas sampled (Figure 3.5). The relationship found between RMRI and herbaceous cover is likely representative of 
reduced herb cover in plots with high earthworm impacts. Herbaceous cover does not take into account habitat class or invasive species as plots could be fully covered in exotic graminoids or native forbs and shrubs. Sedges (Carex spp.) and shield ferns (Dryopteris spp.), the two most abundant plant groups, are known to increase with earthworm abundance (Holdsworth et al., 2007; Corio et al., 2009; Fisichelli et al., 2012). Though only variables potentially influenced by their presence were significantly correlated with RMRI and not significant themselves, earthworms have been shown to disturb nutrient uptake enough to alter tree ring widths (Larson et al., 2010).

The lower, long term BAI of trees in stands with abundant earthworm evidence, higher total soil $\mathrm{C}$, and higher soil $\mathrm{Mn}$ is probably indicative of long-term presence of earthworms in these stands, many of which are near towns and areas with a long history of heavy human disturbance (Stearns, 1997). The lower average BAI of trees with earthworms present is also more static (rather than more positive) than other trees and indeed, individual stands and trees within the model have declining BAI's. That the average BAI is steadily positive until the 1980s to 1990 s, then flattening out in stands with less evidence of earthworms but still some forest floor disturbance, suggests more recent and ongoing invasions.

\section{Conclusion}

Few, if any, reports of current sugar maple decline mention earthworms, or attempts to measure them as a variable impacting tree health along with nutrients, climate, or other influences. Part of the reason for this is that earthworms have long been established in areas of the eastern U.S. and may not have been considered as an exotic species (Coderre et al., 1995; Hendrix and Bohlen 2002). As the forest floor is consumed and tree roots die, trees go through a stress period and have to reestablish their fine root network deeper into the mineral soil. Hypothetically, once roots are reestablished, tree growth may stabilize, and stress effects of earthworms on the trees may be diminished despite the fact that the earthworms have significantly altered the forest floor conditions.

The correlative evidence for multiple factors associated with sugar maple dieback highlights the need for studies to be comprehensive when determining sugar maple health 
etiologies, especially including key soil organisms and conditions. Site requirements and earthworm impacts should be further assessed for other northern hardwood species in addition to sugar maple, especially if a management recommendation is to promote species diversity. Sugar maple health and growth in the Great Lakes warrants further investigation and monitoring.

\section{Acknowledgements}

This research was supported by GMO, LLC and the USDA Forest Service Forest Health Monitoring Program. The foresters at American Forest Management, the U.S. Forest Service, and MI DNR were invaluable in their assistance in locating sugar maple stands with dieback. Eric Lilleskov, USFS, provided us with the earthworm impact rating scale. Thanks to Chris Webster, Michigan Tech, for providing use of the tree ring reader. Dana Richter, Eric Lilleskov, Robert Heyd, Joseph O’Brien, and Manfred Mielke provided many early comments and assistance throughout the course of this project. We are also grateful to the field technicians that helped core trees and process samples: Sally Sanderson, Amy Berns, James Klapperich, Chad Fortin, Christine Jones, Melissa Porter, Donavon Young, Will Schultz, Eric Hollenbeck, Andrew Beebe, Sunshine Love, Alex Larsen, Kurt Lehman, and Jonathon Malette.

\section{References}

Allen, D.C., Barnett, C.J., Millers, I., Lachance, D. 1992. Temporal change (1988-1990) in sugar maple health, and factors associated with crown condition. Can. J. For. Res. 22: 1776-1784.

Anderson, G.W., Schmiege, D.C. 1959. The forest insect and disease situation Lake States 1958. USDA For. Ser. Station Paper No 70.

Bal, T.L., Richter, D.L., Storer, A.J., Jurgensen, M.F. 2013. The relationship of the sapstreak fungus, Ceratocystis virescens to sugar maple dieback and decay in northern Michigan. Am. J. Plant Sci. 4:436-443.

Bernier, B., Brazeau, M. 1988. Nutrient deficiency symptoms associated with sugar maple dieback and decline in the Quebec Appalachians. Can. J. For. Res. 18: 762767.

Boddy, L., Rayner, A.M., 2006. Origins of decay in living deciduous trees: the role of moisture content and a re-appraisal of the expanded concept of tree decay. New Phytol. 94: 623-641. 
Casson, N.J., Eimers, M.C., Watmough, S.A. 2012. An assessment of the nutrient status of sugar maple in Ontario: indications of phosphorus limitation. Environ. Monit. Assess. 184: 5917-5927.

Coderre, D., Mauffette, Y., Gagnon D., Tousignant ,S., Bessette G. 1995. Earthworm populations in healthy and declining sugar maple forests. Pedobiologia 39:86-96.

Coffman, M.S., Alyanak, E., Kotar, J., Ferris, J.E. 1984. Field Guide Habitat Classification System for Upper Peninsula of Michigan and northeast Wisconsin. Cooperative Research on Forest Soils; School of Forestry and Wood Products, Michigan Technological University, Houghton, MI.

Corio, K., Wolf, A., Draney, M., Fewless, G. 2009. Exotic earthworms of Great Lakes Forests: A search for indicator plant species in maple forests. Forest Ecol. Manag. 258: 1059-1066.

Dempsey, M.A., Fisk, M.C., Fahey, T.J. 2011. Earthworms increase the ratio of bacteria to fungi in northern hardwood forest soils, primarily by eliminating the organic horizon. Soil Biol. Biochem. 43: 2135-2141.

Drohan, P.J., Stout, S.L., Petersen, G.W. 2002. Sugar maple (Acer saccharum Marsh.) decline during 1979-1989 in northern Pennsylvania. Forest Ecol. Manage. 170: 1-17.

Duchesne, L., Ouimet, R., Houle D. 2002. Basal area growth of sugar maple in relation to acid deposition, stand health, and soil nutrients, J. Environ. Qual. 31: 1676-1683.

Fisichelli, N.A., Frehlich, L.E,. Reich, P.B., Eisenhauer, N. 2012. Linking direct and indirect pathways mediating earthworms, deer, and understory composition in Great Lakes forests. Biol. Invasions. 15: 1057-1066.

Fisk, M.C., Fahey, T.J., Groffman, P.M., Bohlen, P.J. 2004. Earthworm invasion, fineroot distributions, and soil respiration in north temperate forests. Ecosystems 7:55-62

Groffman, P. M., Bohlen, P.J., Fisk, M.C., Fahey, T.J. 2004. Exotic earthworm invasion and microbial biomass in temperate forest soils. Ecosystems 7:45-54.

Hale, C.M., 2007. Earthworms of the Great Lakes. Kollath-Stensaas, Duluth, MN. 36 pgs.

Hale, C.M, Frehlich, L.E., Reich, P.B. 2006. Changes in cold-temperate hardwood forest understory plant communities in response to European earthworm introductions. Ecology 87: 1637-1649.

Hale, C.M., Frelich, L.E., Reich, P.B., Pastor, J. 2005. Effects of European earthworm invasion on soil characteristics in northern hardwood forests of Minnesota, U.S.A. Ecosystems 8: 911-927.

Hale, C.M., Frelich, L.E., Reich, P.B., Pastor, J. 2008. Exotic earthworm effects on hardwood forest floor, nutrient availability and native plants: a mesocosm study. Oecologia 155: 509-518.

Hendrix, P.F., Bohlen, P.J. 2002. Exotic earthworm invasions in North America: ecological and policy implications. BioScience 52: 801-811

Holdsworth, A.R., Frehlich, L.E., Reich, P.B. 2007. Regional extent of an ecosystem engineer: earthworm invasion in northern hardwood forests. Ecol. Appl. 17: 16661677.

Holdsworth, A.R., Frehlich, L.E., Reich, P.B. 2012. Leaf litter disappearance in earthworm-invaded northern hardwood forests: role of tree species and the chemistry and diversity of litter. Ecosystems 15: 913-926. 
Horsley, S.B., Long, R.P., (Editors) 1999. Sugar Maple Ecology and Health: An International Symposium. Warren, MI. June 2-4, 1998. USDA Forest Service Gen. Tech. Rep. NE-26.

Horsley, S.B., Long, R.P., Bailey, S.W., Hallett, R.A., Hall, T.J. 2000. Factors associated with the decline disease of sugar maple on the Allegheny Plateau. Can J. For. Res. 30: $1365-1378$.

Houston, D.R. 1992. A host-saprogen model for forest dieback-decline diseases. P. 3-25 in Forest decline concepts, Manion, P.D., and D.Lachance (eds.). APS Press, New York.

Huggett, B.A., Schaberg, P.G., Hawley, G.J., Eagar, C. 2007. Long-term calcium addition increases growth release, wound closure, and health of sugar maple (Acer saccharum) trees at the Hubbard Brook Experimental Forest. Can. J. For. Res. 37: 1692-1700.

Kessler, K.J. Jr. 1965. Dieback of managed, old growth northern hardwoods in upper Michigan, 1954-1964: A case history. Plant Dis. Rep. 49: 483-486.

Kolb, T.E., McCormick, L.H. 1993. Etiology of a sugar maple decline in four Pennsylvania stands. Can. J. For. Res. 23: 2395-2402.

Larson, E.R., Kipfmueller, K.F., Hale, C.M., Frelich, L.E., Reich, P.B. 2010. Tree rings detect earthworm invasions and their effects in northern Hardwood forests. Biol. Invasions 12: 1053-1066.

Lawrence, B., Fisk, M.C., Fahey, T.J., Suarez, E.R. 2001. Influence of nonnative earthworms on mycorrhizal colonization of sugar maple (Acer saccharum). New Phytol. 157: 145-153.

Lorimer, C.G., Dahir, S.E., Singer, M.T. 1999. Frequency of partial and missing rings in Acer saccharum in relation to canopy position and growth rate. Plant Ecol. 143: 189202.

Loss, S.R., Hueffmeier, R.M., Hale, C.M., Host, G.E., Sjerven, G., Frelich, L.E. 2013. Earthworm invasions in northern hardwood forests: a rapid assessment method. Nat. Area. J. 33: 21-30.

McLaughlin, D.L., Linxon, S.N., Dimma, D.E., McIlveen, W.D. 1987. Sugar maple decline in Ontario. In: Hutchison, T.C., Meema, K.M., (Eds), Effects of atmospheric pollutants on forests, wetlands, and agricultural ecosystems. Springer-Verlag, New York, pp. 101-116.

Mader, D.L., Thompson, B.W. 1969. Foliar and soil nutrients in relation to sugar maple decline. Soil Sci. Amer. Proc. 33: 794-800.

Manion, P.D. Lachance, D., (eds) 1992. Forest Decline concepts. American Phytopathological Society, St. Paul, MN

Michigan Department of Natural Resources and Environment, Forest Management Division, 2009 Michigan Forest Health Highlights. http://fhm.fs.fed.us/fhh/fhh_09/mi_fhh_09.pdf

Michigan Department of Natural Resources and Environment, Forest Management Division, 2010 Michigan Forest Health Highlights. http://fhm.fs.fed.us/fhh/fhh_10/mi_fhh_10.pdf 
Michigan Department of Natural Resources and Environment, 2012. Forest Management Division, 2012 Michigan Forest Health Highlights http://www.midnr.com/Publications/pdfs/ForestsLandWater/ForestHealth/FHH.pdf

Millers, I., Shriner, D.S., Rizzo, D. 1989. History of hardwood decline in the Eastern United States. Gen. Tech. Rep. NE-126. Broomall, PA: U.S. Department of Agriculture, Forest Service, Northeastern Forest Experiment Station, 75 p.

Ohman, J.H. 1970. Value loss from skidding wounds in sugar maple and yellow birch. J. Forestry 68: 226-230.

Pare, D., Bernier, B. 1989. Origin of the phosphorus deficiency observed in declining sugar maple stands in the Quebec Appalachians. Can. J. For. Res. 19: 24-34.

Reich, P.B., Oleksyn, J., Modryznski, J., Mrozinski, P., Hobbie, S.E., Eissesnstat, D.M., Chorover, J., Chadwick, O.A., Hale, C.M., Tjoelker, M.G. 2005. Linking litter calcium, earthworms and soil properties: a common garden test with 14 tree species. Ecol. Lett. 8: 811-818.

Sackett, T.E., Smith, S.M., Basiliiko, N. 2012. Exotic earthworm distribution in a mixeduse northern temperate forest region: influence of disturbance type, development age, and soils. Can. J. For. Res. 42: 375-381.

SanClements, M.D., Fernandez, I.J., Norton, S.A. 2010. Phosphorus in soils of temperate forests: linkages to acidity and aluminum. Soil Sci. Soc. Am. J. 74: 2175-2186.

Schmiege, D.C., Anderson, G.W. 1960. The forest insect and disease situation, Lake States, 1959. USDA For. Ser. Station Paper No 79.

Shartell, L.M., Corace, R.G., Storer, A.J. 2012. Exotic earthworm communities within upland deciduous forests of national wildlife refuges in the upper Midwest. J. Fish Wildlife Manage. 3: 332-340.

Shartell, L.M., Lilleskov, E.A., Storer, A.J. 2013. Predicting exotic earthworm distribution in the northern Great Lakes Region. Biol. Invasions. Published online 12013.

Silva, L.R., Anand, M., Leithead, M.D. 2010. Recent widespread tree growth decline despite increasing atmospheric $\mathrm{CO}_{2}$. PLoS ONE 5: e11543.

Soil Survey Division Staff. 1993. Soil survey manual. Soil Conservation Service. U.S. Department of Agriculture Handbook 18.

Soil Survey Staff, Natural Resources Conservation Service, United States Department of Agriculture. Soil Survey Geographic (SSURGO) Database for counties in WI and MI. Available online at http://soildatamart.nrcs.usda.gov. Accessed 12/1/2012.

St. Clair, S., Sharpe, W. E., Lynch, J.P. 2008. Key interactions between nutrient limitation and climatic factors in temperate forests: a synthesis of the sugar maple literature. Can. J. For. Res. 38: 401-414.

Stearns, F.W. 1997. History of the Lake States Forests: Natural and Human Impacts. P. 829. In Lake States Regional Forest Resources Assessment: Technical Papers.

Vasievich, J.M. and Webster, H.H. (eds.) USDA Forest Service, North Central Forest Experiment Station, Gen-Tech-Rep NC-189.

U.S. Department of Agriculture, Forest Service, "Forest Health Monitoring 1999 Field Methods Guide." USDA Forest Service, National Forest Health Monitoring Program, Research Triangle Park, NC, 1999. 
Watmough, S.A., Hutchinson, T.C., Dillon, P.J. 2004. Lead dynamics in the forest floor and mineral soil in south central Ontario. Biogeochemistry 71:43-68

Watmough, S.A., 2010. Assessment of the potential role of metals in sugar maple (Acer saccharum Marsh) decline in Ontario, Canada. Plant Soil 332: 463-474.

Wironen, M., Moore, T.R. 2006. Exotic earthworm invasion increases soil carbon and nitrogen in an old-growth forest in southern Quebec. Can. J. For. Res. 36: 845-854. 
Table 3.1. The five point rating system for earthworm impacts for assessing forest floor condition in northern hardwood forests. Ratings are assigned for a $1 \mathrm{~m}^{2}$ quadrant in the four cardinal directions and averaged per plot. (E. Lilleskov, Northern Research Station, USDA Forest Service, pers. comm., May 19, 2010)

\section{Rating Description of class rating characteristics}

1 No forest floor. Previous year's litter over mineral soil. Worm castings and/or Lumbricus terrestris L. middens abundant.

2 No humus, or small leaf fragments present; larger old leaves may be present under litter. Worm castings present; L. terrestris middens present or absent. Roots absent from forest floor.

3 No humus. Small leaf fragments and larger old leaves present. Sparse to no roots in the forest floor. Some worm castings may be present. L. terrestris likely to be absent or very sparse.

$4 \quad$ Humus present in patches, may be slightly mixed with mineral soil, the rest of the forest floor is intact. Some roots in the forest floor, but not thick. Small worms may be found in the forest floor, but no large castings or L. terrestris middens.

5 Humus fully intact. Roots present in humus and leaf fragments. Forest floor coherent when picked up with intact recognizable layers. No worm sign present. 
Table 3.2. Mean, minimum and maximum values for plot characteristics for 120 plots established to assess sugar maple dieback in the western Upper Great Lakes.

\begin{tabular}{|c|c|c|c|}
\hline & mean & $\min$ & $\max$ \\
\hline 2011 live sugar maple $\mathrm{m}^{2}$ basal area/acre & 30.6 & $12.2^{\mathrm{a}}$ & 61.4 \\
\hline 2011 live total $\mathrm{m}^{2}$ basal area/acre & 25.2 & $6.8^{\mathrm{a}}$ & 49.2 \\
\hline 2010 sugar maple height (m) & 16.9 & 2.4 & 32.0 \\
\hline 2012 sugar maple d.b.h. $(\mathrm{cm})$ & 23.4 & 10.1 & 69.3 \\
\hline \multicolumn{4}{|l|}{3 or 4 year average ${ }^{b}$} \\
\hline sugar maple seedling count ( $1.12 \mathrm{~m}$ radius $)$ & 12.5 & 0 & 69.4 \\
\hline sugar maple sapling count ( $3.59 \mathrm{~m}$ radius) & 1.7 & 0 & 12.5 \\
\hline \multicolumn{4}{|l|}{ Percent of live sugar maple with: } \\
\hline cankers (Nectria or Eutypella spp.) & 13.6 & 0 & 76.5 \\
\hline sugar maple borer & 21.6 & 0 & 55.5 \\
\hline wounds (all causes, logging, seams, burls) & 19.5 & 0 & 63.6 \\
\hline logging wounds & 3.8 & 0 & 34.8 \\
\hline wound size $\left(\mathrm{m}^{2}\right)$ & 5.4 & 0.1 & 59.8 \\
\hline visible vertical seams & 7.0 & 0 & 37.5 \\
\hline visible vertical seam length (m) & 2.2 & 0.3 & 6.1 \\
\hline obvious decay in bole (including cankers) & 30.8 & 0 & 100.0 \\
\hline \multicolumn{4}{|l|}{ Average plot values for sugar maple } \\
\hline crown transparency & 47.1 & 32.5 & 65.0 \\
\hline crown density & 51.3 & 19.7 & 62.8 \\
\hline crown light exposure ( 0 though 5 side and top) & 1.43 & 0.71 & 4.33 \\
\hline uncompacted live crown ratio & 45.5 & 29.8 & 62.4 \\
\hline dwarf, discolored, defoliated, or curled foliage (\% $\mathrm{n}$ ) & 21.1 & 0 & 76.9 \\
\hline crown dieback (excluding $100 \%$ dead initial survey year) & 12.4 & 0.8 & 75.5 \\
\hline \multicolumn{4}{|l|}{ Average plot values } \\
\hline 2010 herbaceous $\%$ cover & 21.6 & 0 & 100 \\
\hline 2010 herbaceous richness & 7.3 & 0 & 16 \\
\hline slope (degrees) & 5.3 & 0 & 35 \\
\hline distance to Lake Superior $(\mathrm{km})$ & 28.6 & 0.9 & 105.5 \\
\hline elevation (m) & 451.6 & 213.4 & 596.4 \\
\hline earthworm impact rating (5 point scale) & 3.3 & 1.0 & 5.0 \\
\hline total percent canopy cover & 90.6 & 60.8 & 99.0 \\
\hline
\end{tabular}

${ }^{a}$ not including plots that had been harvested during study.

${ }^{\mathrm{b}}$ Public land plots were measured 2010, 2011, and 2012 while private land plots were established in 2009 and thus have 4 years of data. 
Table 3.3. Pearson correlations and stepwise regression results for average sugar maple dieback (2009-2012) excluding initially dead trees in the Western Upper Great Lakes region $(\mathrm{n}=120$ plots) with general plot variables (excluding soil nutrients). Bold and italics indicate significance $(\mathrm{p}<0.05)$, bold alone indicates approaching significance $(\mathrm{p}<0.1)$.

\begin{tabular}{lcc}
\hline \hline Plot variable & Correlation & $\mathrm{P}$ \\
\hline slope $(\%)$ & -0.062 & 0.739 \\
Aspect & 0.238 & 0.197 \\
topographic position $(1=$ summit, $5=$ flat $)$ & -0.179 & 0.333 \\
elevation $(\mathrm{m})$ & 0.139 & 0.457 \\
distance to Lake Superior $(\mathrm{km})$ & 0.099 & 0.958 \\
average pit and mound relief $(\mathrm{cm})$ & 0.062 & 0.266 \\
average mineral soil $\mathrm{pH}$ & 0.161 & 0.386 \\
average earthworm impact rating & $\mathbf{- 0 . 2 6 9}$ & $\mathbf{0 . 0 1 4}$ \\
herbaceous cover $\left(\%\right.$ in $\left.1 \mathrm{~m}^{2}\right)$ & 0.082 & 0.661 \\
herbaceous richness & -0.045 & 0.811 \\
herbaceous diversity $($ Shannon's index) & -0.262 & 0.155 \\
average sugar maple dbh & -0.223 & 0.229 \\
average sugar maple height & -0.165 & 0.375 \\
years since last harvest (pre-2009) & 0.339 & 0.168 \\
live total basal area ( $\mathrm{m}^{2} /$ ha) & 0.082 & 0.659 \\
live SM basal area ( ${ }^{2} /$ ha) & -0.217 & 0.241 \\
average SM seedling count $(1.12 \mathrm{~m}$ radius) & 0.164 & 0.379 \\
average \% total canopy cover & $\mathbf{- 0 . 3 4 4}$ & $\mathbf{0 . 0 5 8}$ \\
average \% with sugar maple borer & 0.164 & 0.379 \\
average \% with wounds/damage & $\mathbf{0 . 3 4 9}$ & $\mathbf{0 . 0 5 4}$ \\
average \% with abnormal foliage & -0.104 & 0.576 \\
average \% with cankers & $\mathbf{- 0 . 3 0 3}$ & $\mathbf{0 . 0 9 7}$ \\
\hline
\end{tabular}


Table 3.4. Pearson correlations and stepwise regression results for average sugar maple dieback (2009-2012) excluding initially dead trees in the Western Upper Great Lakes region ( $\mathrm{n}=120$ plots) with general plot variables, mean plot soil nutrients, and soil survey information. Bold and italics indicate significance $(p<0.05)$, bold alone indicates approaching significance $(\mathrm{p}<0.1)$.

\begin{tabular}{|c|c|c|}
\hline Variable & Correlation & $\mathrm{P}$ \\
\hline slope $(\%)$ & 0.043 & 0.833 \\
\hline Aspect & 0.010 & 0.962 \\
\hline topographic position ( $1=$ summit, $5=$ flat $)$ & -0.038 & 0.853 \\
\hline elevation (m) & -0.195 & 0.330 \\
\hline distance to Lake Superior $(\mathrm{km})$ & 0.046 & 0.820 \\
\hline average pit and mound relief $(\mathrm{cm})$ & 0.343 & 0.080 \\
\hline average mineral soil $\mathrm{pH}$ & 0.239 & 0.231 \\
\hline average earthworm impact rating & 1.176 & 0.010 \\
\hline herbaceous cover (\% in $\left.1 \mathrm{~m}^{2}\right)$ & 0.160 & $<0.001$ \\
\hline herbaceous richness & 0.129 & 0.522 \\
\hline herbaceous diversity (Shannon's index) & 0.184 & 0.359 \\
\hline average sugar maple d.b.h. & 0.213 & 0.287 \\
\hline average sugar maple height & 0.079 & 0.694 \\
\hline years since last harvest (pre-2009) & -0.211 & 0.292 \\
\hline live total basal area $\left(\mathrm{m}^{2} / \mathrm{ha}\right)$ & -0.001 & 0.996 \\
\hline live SM basal area (m2/ha) & 0.032 & 0.875 \\
\hline average SM seedling count ( $1.12 \mathrm{~m}$ radii) & 0.004 & 0.985 \\
\hline average $\%$ total canopy cover & -0.266 & 0.179 \\
\hline average $\%$ with sugar maple borer & 0.079 & 0.695 \\
\hline average $\%$ with wounds/damage & -0.085 & 0.675 \\
\hline average $\%$ with abnormal foliage & 0.255 & 0.199 \\
\hline average $\%$ with cankers & 0.007 & 0.972 \\
\hline average $\%$ sand (top $30 \mathrm{~cm})$ & 0.078 & 0.700 \\
\hline average $\%$ silt (top $30 \mathrm{~cm}$ ) & 0.064 & 0.752 \\
\hline average $\%$ clay $($ top $30 \mathrm{~cm})$ & -0.006 & 0.977 \\
\hline dominant particle size (1-3) & 0.003 & 0.990 \\
\hline average soil density, $(7-45 \mathrm{~cm}, \mathrm{kPa})$ & -0.263 & 0.185 \\
\hline depth to bedrock $(\mathrm{cm})$ & -0.015 & 0.941 \\
\hline$C$ (total \% in mineral soil) & 0.768 & $<0.001$ \\
\hline $\mathrm{N}$ (total \% in mineral soil) & 0.112 & 0.579 \\
\hline $\mathrm{K}(\mathrm{mg} / \mathrm{kg})$ & 0.120 & 0.552 \\
\hline $\mathrm{Mg}(\mathrm{mg} / \mathrm{kg})$ & -0.165 & 0.411 \\
\hline $\mathrm{Ca}(\mathrm{mg} / \mathrm{kg})$ & -0.082 & 0.683 \\
\hline
\end{tabular}




\begin{tabular}{lrr}
$\mathrm{Al}(\mathrm{mg} / \mathrm{kg})$ & -0.018 & 0.930 \\
$\mathrm{Na}(\mathrm{mg} / \mathrm{kg})$ & 0.168 & 0.403 \\
$\mathrm{C} / \mathrm{N}(\mathrm{molar}$ ratio) & -0.126 & 0.533 \\
$\mathrm{Ca} / \mathrm{AL}(\mathrm{molar}$ ratio) & -0.240 & 0.228 \\
effective CEC (cmolc/kg) & -0.117 & 0.560 \\
$\mathbf{M n}(\mathbf{m g} / \mathbf{k g})$ & $\mathbf{0 . 0 7 0}$ & $<\mathbf{0 . 0 0 1}$ \\
$\mathrm{Fe}(\mathrm{mg} / \mathrm{kg})$ & 0.094 & 0.642 \\
$\mathrm{Ni}(\mathrm{mg} / \mathrm{kg})$ & 0.046 & 0.821 \\
$\mathrm{Cu}(\mathrm{mg} / \mathrm{kg})$ & -0.002 & 0.993 \\
$\mathrm{Zn}(\mathrm{mg} / \mathrm{kg})$ & -0.202 & 0.314 \\
$\mathrm{Cd}(\mathrm{mg} / \mathrm{kg})$ & -0.172 & 0.391 \\
$\mathrm{~Pb}(\mathrm{mg} / \mathrm{kg})$ & -0.291 & 0.141 \\
$\mathrm{SO} 4 \mathrm{~S}(\mathrm{mg} / \mathrm{kg})$ & -0.036 & 0.860 \\
average $\%$ organic loss on ignition & -0.279 & 0.158 \\
oxides present in subgroup & 0.147 & 0.465 \\
saturation in subgroup & 0.147 & 0.465 \\
presence of fragipan & 0.063 & 0.757 \\
surface runoff class $(1-5)$ & 0.152 & 0.449 \\
drainage index & 0.160 & 0.424 \\
drainage class $(1-5)$ & 0.145 & 0.471 \\
seedling mortality class $(1-3)$ & 0.243 & 0.222 \\
depth to high water table (m) & -0.056 & 0.781 \\
potential for frost action $(1-3)$ & 0.185 & 0.357 \\
\hline
\end{tabular}




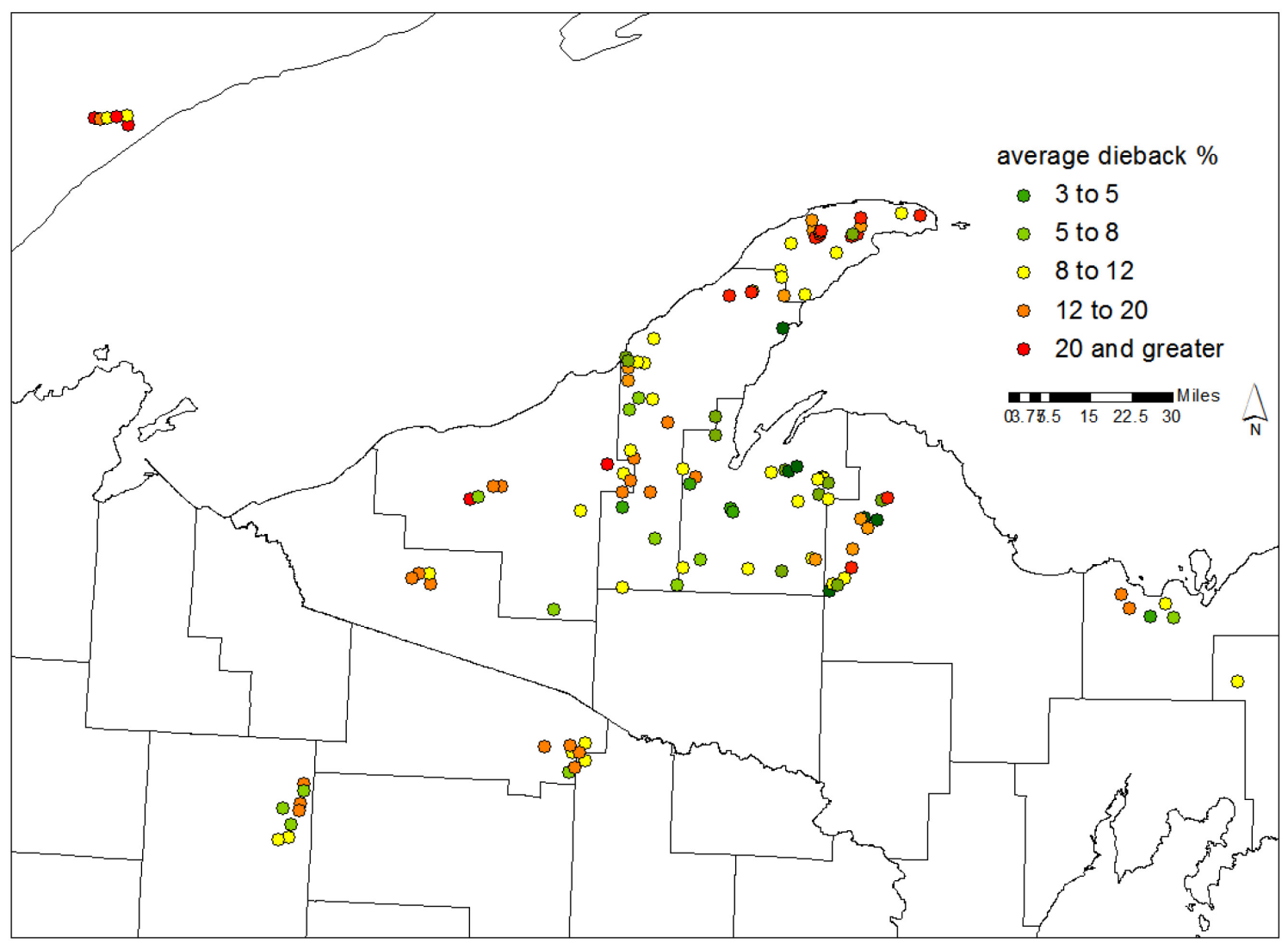

Figure 3.1. Sugar Maple Health Assessment Plot distribution across Michigan, northern Wisconsin, and eastern Minnesota and mean plot sugar maple dieback from establishment year (2009-2010) to 2012 excluding initially dead trees. 

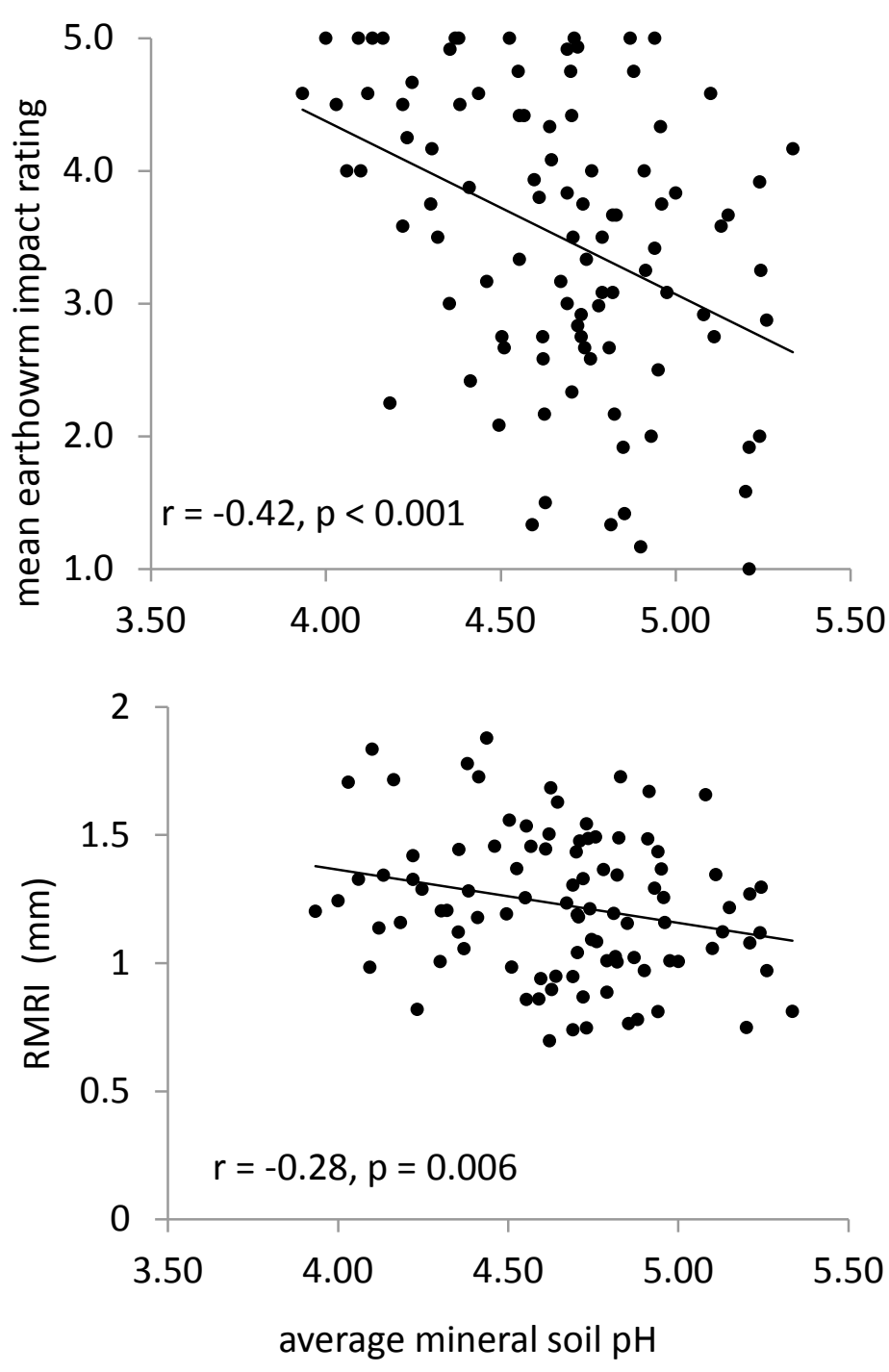

Figure 3.2. The relationships between mineral soil $\mathrm{pH}$, the average earthworm impact rating and RMRI (recent mean radial increment: 2003-2008) for sugar maple health evaluation plots in the western Upper Great Lakes Region.. 

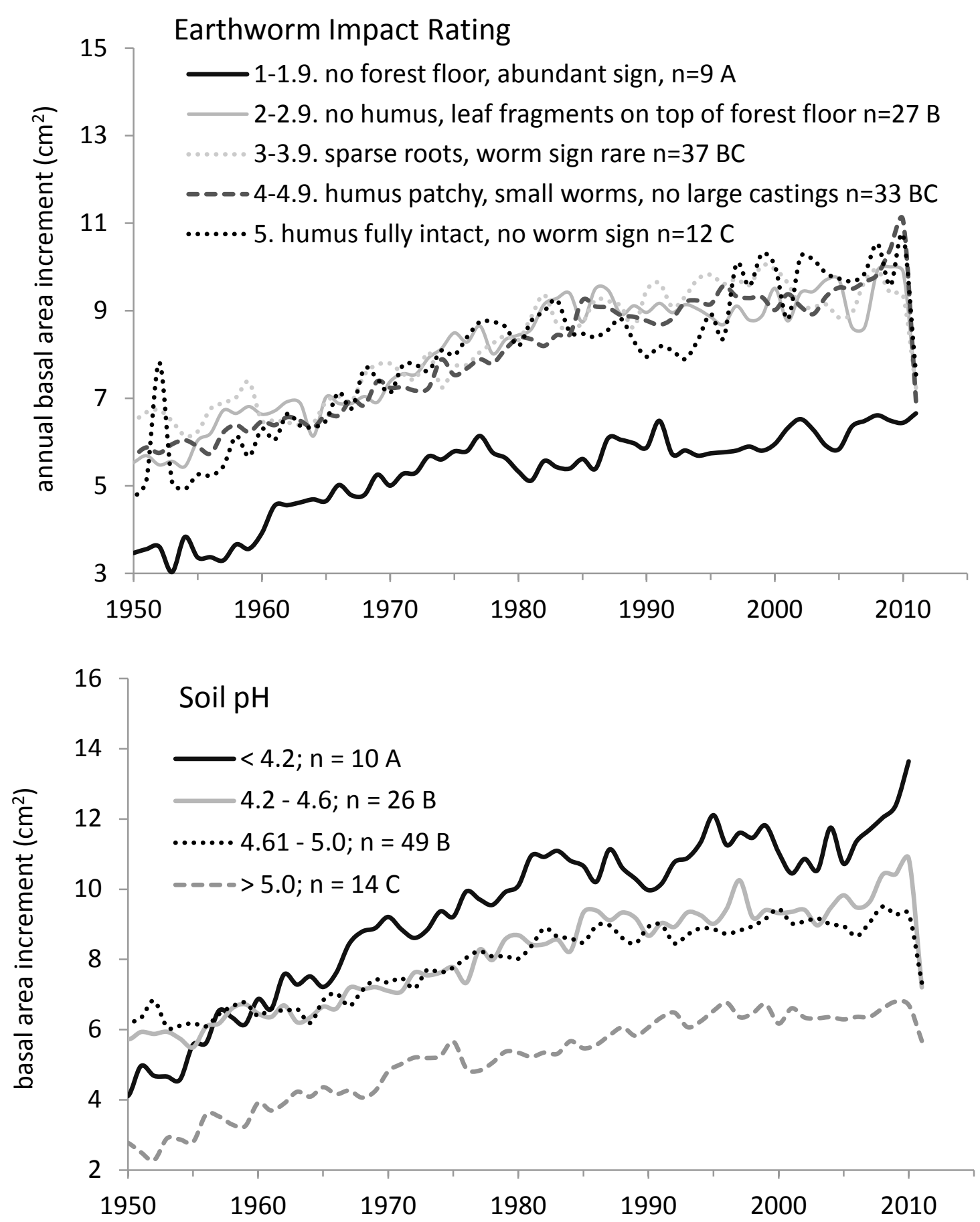

Figure 3.3. Mean annual basal area increment of sugar maple trees $(n=313)$ in the western Upper Great Lakes Region stratified by mean plot rating (2009-2012) of earthworm impacts on the forest floor and average plot mineral soil $\mathrm{pH}$. Letters indicate significant differences between mean BAI chronologies (repeated measures analysis, $\alpha=0.05$ ) while $\mathrm{n}$ indicates the number of plots in each category. 

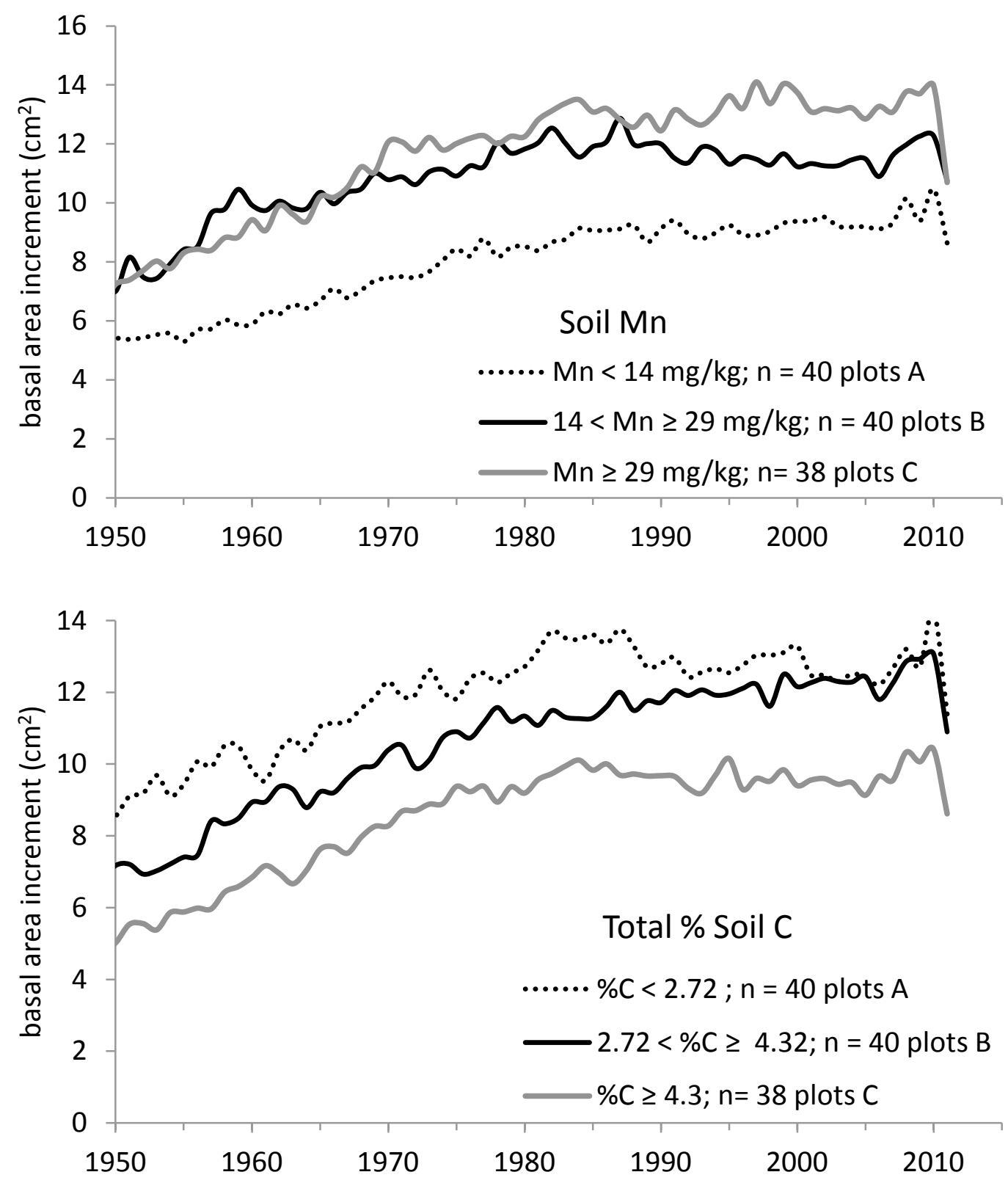

Figure 3.4. Mean annual basal area increment of trees sugar maple trees ( $\mathrm{n}$ trees $=313$ ) in the western Upper Great Lakes Region stratified by mean plot mineral soil Mn (mg/kg) and percent total soil C (top 30cm, from sampling year 2009-2012). Letters indicate significant differences between mean BAI chronologies (repeated measures analysis, $\alpha=$ 0.05 ) while $\mathrm{n}$ indicates the number of plots in each category. 


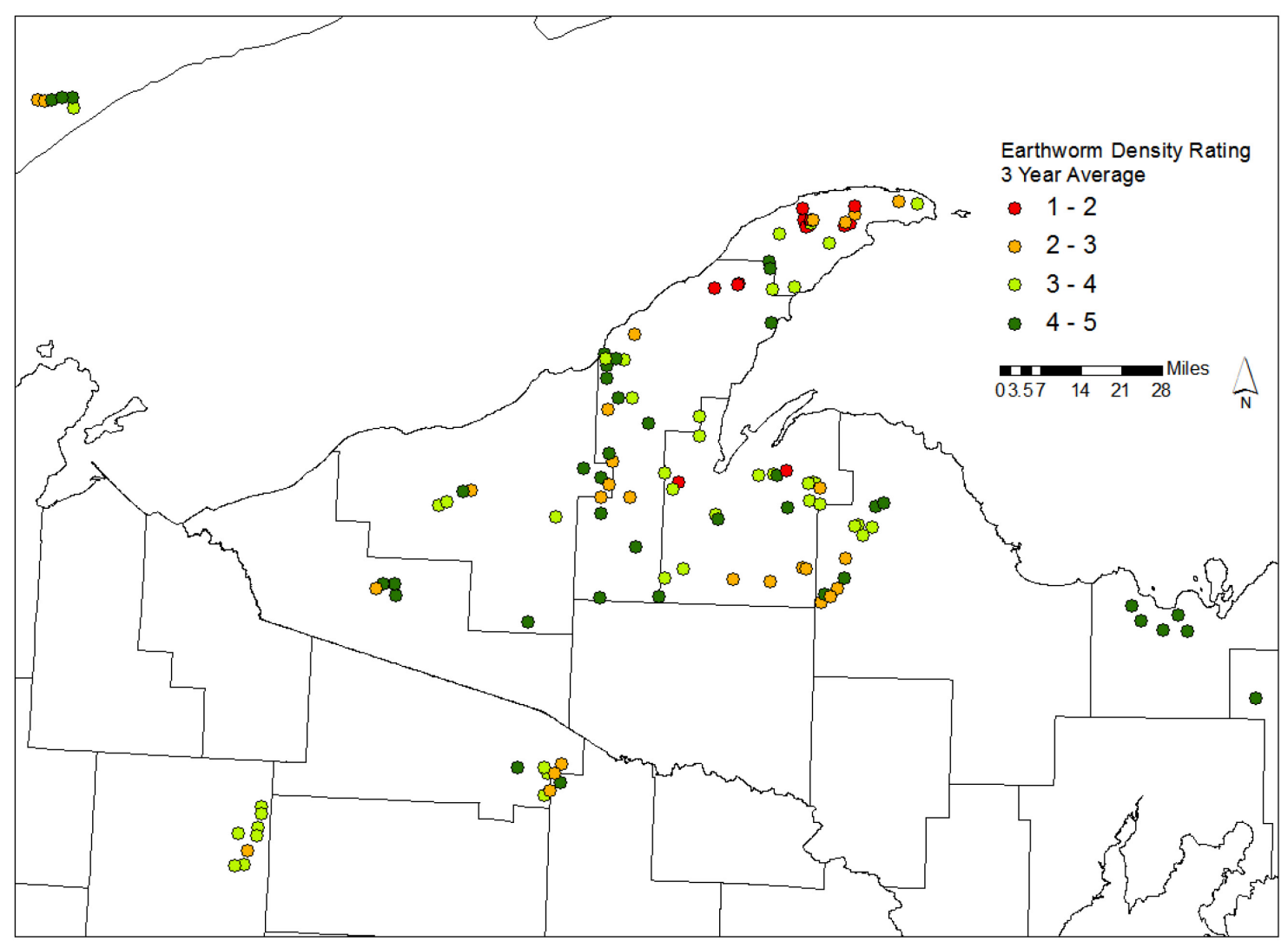

Figure 3.5. Sugar Maple Health Assessment Plot average earthworm density and abundance rating (developed by Eric Lilleskov, USDA Forest Service) for 2010, 2011, and 2012. Rating 1 is no forest floor, while a rating of 5 is forest floor completely intact. 


\title{
Chapter 4
}

\section{Sugar Maple Health and Relationships with Foliar and Soil Nutritional Status in the Western Upper Great Lakes Region $^{3}$}

\begin{abstract}
Increased reports of sugar maple (Acer saccharrum Marsh.) crown dieback in the western Upper Great Lakes region have recently prompted investigation of the nutritional status of sugar maple across the region. Sugar maple dieback assessment from 20092012 across a 120 plot network in Upper Michigan, northern Wisconsin, and eastern Minnesota included basal area increment, element concentrations of foliage and soil elements, soil $\mathrm{pH}$, and earthworm impacts on the forest floor in order to determine factors associated with decreasing crown conditions. Relationships determined between foliar and soil nutrients correlated with the current dieback and growth of sugar maple in the western Upper Great Lakes region. Mean sugar maple dieback was significantly correlated to foliar $\mathrm{N}, \mathrm{K}, \mathrm{S}, \mathrm{Cu}, \mathrm{Cd}, \mathrm{Sr}$, and edaphic variables of $\mathrm{Al}, \mathrm{Cu}$, and $\mathrm{Mg}$ concentrations, soil $\mathrm{pH}$, and earthworm impacts. Examination of translocation efficacy indicated that $\mathrm{Zn}$ resorption significantly increased with increasing dieback. Basal area increment varied significantly between low, sufficient, and high nutrient thresholds and soil pH levels. The recent mean radial growth (2003-2008) was significantly correlated to foliar $\mathrm{Al}, \mathrm{Fe}, \mathrm{Zn}, \mathrm{Cd}, \mathrm{Ni}, \mathrm{Na}$, and soil $\mathrm{pH}$. This study presents significant evidence suggesting sugar maple dieback in the western Great Lakes Region is related to nutritional status and perturbation possibly due in part to earthworm impacts. The interaction between nutrient imbalances, earthworm invasion, climate variables, and anthropogenic inputs needs to be further studied for sugar maple and other species in the Great Lakes Region.
\end{abstract}

3 The material in this chapter is planned for submission in the near future and is formatted as such. 


\section{Introduction}

Many factors have been identified as affecting sugar maple (Acer sacharrum Marsh.) health, growth, and survival including climate (drought, heat, freezing, thawing), biotic organisms, stand maturation, logging or tapping injuries, soil fertility, and forest management (Houston, 1987; Millers et al., 1989; Horsley and Long, 1999). The general consensus is that sugar maple, like other species, is most likely influenced by a combination of factors leading up to the reduction in growth and vigor and eventually leading to crown dieback and stand decline (Houston, 1981; Houston, 1987). Since the late 1980's, there has been an emphasis in sugar maple health literature on nutrient stress, with this being one of the most common predisposing factors associated with many dieback and decline events reported across the range of sugar maple (Kolb and McCormick, 1983; Bernier and Brazeau, 1988a and b; Bernier et al., 1989; Foster etal.,1989; Pare and Bernier, 1989; Foster et al., 1992; Wilmot et al., 1995; Horsley and Long, 1999; Watmough et al., 1999; Drohan et al., 2002; Hallet et al., 2006; Long et al., 2009; and others).

Perturbations in soil biogeochemistry have been linked to climate change. St. Clair et al. (2008) published a comprehensive review of sugar maple physiological responses to mineral stress in the context of climate variability and influence. In general, soil weathering and acidification leads to reduced sugar maple growth and poor crowns. Multiple experiments in climate manipulations (e.g. snow removal, man-made drought) have induced changes in foliar and/or soil nutrients in northern hardwoods in as little as one year (Pilon et al., 1994; Auclair, et al., 1995; Pilon et al., 1996; Groffman et al., 2001). Acidic atmospheric deposition and anthropogenic disturbance can also cause changes in soil chemistry through acidification and leaching (Manion and Lachance 1992; Drohan and Sharpe 1997). Soil biota, particularly exotic, invasive earthworms, can alter soil nutrient cycles, temperature and moisture regimes, and microorganism assembles supportive of nutrient acquisition. When biotic or abiotic stress events occur in a stand with imbalanced nutrient levels, regardless of the underlying cause, dieback leading to decline may become widespread throughout an area. 
Sugar Maple dieback or decline has been attributed to a single mineral deficiency or limitation (Mader and Thompson, 1969; Bernier and Brazeau 1988c; Paré and Bernier, 1989; Gradowski and Thomas, 2006), multiple deficiencies (Bernier and Brazeau, 1988a and b; Kolb and McCormick, 1993; Wilmot et al., 1995; Liu et al., 1997; Watmough et al., 1999; Park and Yanai, 2009), toxicities (Kogelmann and Sharpe, 2006), or antagonistic behavior among nutrients (Ellsworth and Liu, 1994; Côté et al., 1995; Heisey, 1995; Ouimet et al., 1995; Horsley et al., 2000; Drohan et al., 2002; Duchesne et al., 2002; St. Clair et al., 1995; Hallett et al., 2006; Schaberg et al., 2006; Houle et al., 2007; Long et al., 2009), usually Ca, Mg, Mn, Al, P, K, and N. Some of the more recent reports have been including other micronutrient correlations as well (Heisey 1995; St. Clair and Lynch, 2005; Watmough, 2010; Bilodeau-Gauthier et al., 2011). While nutrient ranges are reported in literature, optimum nutrition for sugar maple is still somewhat unclear as regional conditions in soil type, anthropogenic deposition, and climate conditions vary. Diagnostic Recommendation Integrated System (DRIS) equations have been published for sugar maple nutrition based on some extant datasets and may be useful for diagnosing and prescribing fertilizer (Lozano and Huynh, 1989). Soil type and location appear to be the driver behind which specific nutrients are the most influential on tree health and growth.

Few sugar maple dieback studies have examined nutrients and health relationships across as large a network of plots in the Midwest (Allen et al, 1995; Allen et al., 1999). Recently, sugar maple canopy dieback has been reported and described in the western Upper Peninsula, MI and northern WI (MDNR, 2009, 2010: 2012). The objectives of the research presented included quantifying and determining relationships between foliar and soil nutrients, soil characteristics, growth and dieback symptoms, with the aim of better understanding the etiology driving the current sugar maple dieback in the Western Upper Great Lakes region.

\section{Methods}

\subsection{Plot Establishment}

A network of 120 forest evaluation plots was established in the western Upper 
Great Lakes Region in 2009 and 2010 and revisited each year subsequently throughout 2012. These included 60 plots on industry land in Marquette, Baraga, Houghton, and Keweenaw Counties in Upper Michigan that were established in 2009, and 60 plots on Federal and State public lands in northern Wisconsin, eastern Minnesota, and Upper Michigan that were established in 2010. Plots were located in areas of sugar maple dominated stands with varying levels of dieback, with input from regional foresters.

Plots were at least $40 \mathrm{~m}$ from established roadways to minimize edge effects and an effort was made to include at least 10 sugar maple trees within each 0.04 ha. plot. The canopies of all live trees $<10 \mathrm{~cm}$ diameter at breast height (dbh) were assessed for the percentage of the whole crown that had dieback (0-99\%), including recently dead branches, usually in the upper and outer portions of the crown. Old dead branches, old dead forks, and shaded out branches near the base of the crown were excluded.

In calculating average sugar maple dieback for plots in each year, trees that were harvested were no longer included. Trees that were $100 \%$ dead during the plot establishment year were noted, but not included in the plot average dieback for that year, however, subsequent natural mortality was included in the overall plot dieback average used in models to capture the dead and dying trees during the four year study period.

In addition to tree assessments, the forest floor condition or earthworm impact rating was determined using a 1-5 scale (Hale 2007; Loss et al., 2013). The earthworm impact rating scale quantifies the condition of the forest floor in a one $\mathrm{m}^{2}$ quadrat with 1 having multiple middens and castings present with only the most recent litter on the forest floor and 5 being no evidence of earthworms and a completely intact forest floor (Shartell et al., 2013). The values from 4 quadrats per plot were averaged for a mean plot earthworm impact rating.

\subsection{Foliage Sampling}

At every plot, three dominant or co-dominant trees in a similar size class (ideally within $5 \mathrm{~cm}$ d.b.h.) were sampled for foliage and growth rings. These trees included one with little to no dieback, one with intermediate dieback for the plot, and one with relatively high or the highest dieback for the plot. 
Foliage samples were collected for nutrient analysis from the three trees in August. Foliage was collected from a subset of plots in 2009, 2010, and all remaining plots in 2011. Foliage was removed with a shotgun from mid-canopy and 10 randomly selected leaves were kept frozen until analysis. Small, neonatal terminals were not included and an attempt was made to include only fully formed leaves that were mostly free from herbivory but leaves with mites or gall damage were kept as these occurred frequently. Foliage in the first two weeks of October was also collected on 30 plots on industry lands in 2009 to evaluate nutrient retranslocation efficiency. Retranslocation of nutrients was calculated as the percent difference as the increase or decrease between August and October foliage but not corrected for leaf mass. Leaf area was measured with a Li-Cor LI-3000 leaf area analyzer conveyer (Li-Cor, Inc., Lincoln, Nebraska) and pooled for each tree. Leaves were oven dried at $50^{\circ} \mathrm{C}$ until weight loss was no longer detected and ground with a ball mill to powder and stored in vials from each individual tree. Foliage was analyzed at the Forest Service Rocky Mountain Research Station Forestry Sciences Laboratory, in Logan, Utah, using ICP mass spectrometry analysis with $\mathrm{HNO}_{3}$ and $\mathrm{H}_{2} \mathrm{O}_{2}$ digestion. These analyses yielded values for average plot foliage

concentrations of total N, P, K, Ca, Mg, S, Mn, Fe, Ni, Cu, Zn, B, Na, Sr, Ba, Al, Cr, Cd, and $\mathrm{Pb}$.

\subsection{Tree Core Sampling}

For each of the same three trees used for foliage sampling, two increment cores were collected at 90 degree angles at breast height $(1.4 \mathrm{~m})$ for determination of the mean annual diameter increment per tree, per plot and the recent mean radial increment (RMRI) covering a 5 year span from 2003-2008. All cores were from dominant or codominant canopy trees to reduce the likelihood of partial or missing rings (Lorimer et al., 1999). Cores were refrigerated until being mounted and sanded for reading annual ring widths on a digital measuring stage to the nearest $0.001 \mathrm{~mm}$ using the Measure $\mathrm{J} 2 \mathrm{X}$ software (Voor-Tech Consulting LLC, Nolderness, NH, 1999). Cores were visually cross dated and cores that had significant decay or that were otherwise unreadable were excluded. Data from the two cores from each tree were averaged per year per tree for 
subsequent analysis. Growth chronologies were constructed as mean annual raw ring increment $(\mathrm{mm})$ and mean annual basal area increment (BAI) $\left(\mathrm{cm}^{2}\right)$ using the equation:

$$
\mathrm{BAI}_{\mathrm{t}}=\pi\left(\mathrm{R}_{t}^{2}-\mathrm{R}_{t-1}^{2}\right)
$$

where $\mathrm{R}$ is the tree radius at $\mathrm{dbh}(\mathrm{cm})$ and $t$ is the year of tree ring formation.

The primary goal of collecting such a wide variety of cores was to identify patterns in ring width chronologies of trees reported with recently high levels of crown dieback and determine if commonly reported factors that reduce growth are impacting sugar maples in the Western Great Lakes Region. A variety of age and size classes were sampled to help alleviate potential decrease in growth due to maximum age and ensuring a varied history of competition and release over the study area. Basal area increment is not expected to decrease for sugar maple trees until they are over 100-110 years old (Duchesne et al., 2003) and greater than $45 \mathrm{~cm}$ (17in) d.b.h. (Lorimer and Frelich 1984). We assumed microvariation in ring widths would not significantly impact overall trends in growth. Maple rings are notoriously hard to see and have been shown to have partial or missing rings, but dominant, codominant, and intermediate canopy trees have very few (less than 5\%) ring anomalies (Lorimer et al., 1999).

\subsection{Soil Sampling}

Soil density was measured $6 \mathrm{~m}$ from center in the 4 cardinal directions for a plot average with a Dickey soil penetrometer at approximately every $7.5 \mathrm{~cm}$ interval until $45 \mathrm{~cm}$ or rock. Baseline plot soil samples were collected five paces from center at $0^{\circ}$, $120^{\circ}$, and $240^{\circ}$ for an average plot $\mathrm{pH}$, texture, and rock and organic matter content. Four samples using a $2 \mathrm{~cm}$ diameter soil corer were pooled for each of the three angles, separated by horizon. In 2009 , soils were collected to a $10 \mathrm{~cm}$ depth only, and not separated by horizon as in 2010 and 2011. Samples were oven dried at $50^{\circ} \mathrm{C}$ for 48 hours, crushed, weighed, and sieved. Soil $\mathrm{pH}$ was measured using a 1:1 ratio with deionized water (Digi-Sense 5938-00, Digital pH/mV/ORP). Particle size analysis was done using the hydrometer method with $100 \mathrm{~g}$ of soil and $10 \mathrm{ml}$ of sodium hexametaphosphate solution in a cylinder to estimate the $\%$ of sand, silt and clay particles in solution. Combustible organic matter was measured using loss on ignition determined 
by placing $10 \mathrm{~g}$ samples of each of sample into a muffle oven furnace at $290^{\circ} \mathrm{C}$ for four hours and reweighing immediately afterwards.

Soil samples were also collected with a $2.5 \mathrm{~cm}$ diameter soil corer from beneath the drip lines of two of the three trees with dieback that had foliage sampled. The trees selected were those with the least and the most crown dieback. Under each tree sampled, five, $20 \mathrm{~cm}$ deep cores were pooled together but separated by horizon. Soils were analyzed for exchangeable cations, extractable elements, and extractable $\mathrm{SO}_{4}$-S using ICP mass spectrometry, with $1 \mathrm{M} \mathrm{NH}_{4} \mathrm{Cl}$ digests. A 1:10 extraction ratio was used $(0.5 \mathrm{~g}$ in 25 $\mathrm{mL}$ of extractant). Extracts were diluted 1:10 in deionized water to prepare a better background matrix for ICP analysis. Soil nutrients are analyzed here as concentrations not corrected for horizon mass proportions or total nutrient pools. All soil and foliage nutrient analyses were conducted at the Forest Service, Rocky Mountain Research Station, Forestry Sciences Laboratory, in Logan, Utah.

For regression models for dieback and soil information, soil series data from the Soil Survey Geographic Online Database was gathered (Soil Survey Staff, 2012). Minnesota plot soil survey information was not available. Available soil information and taxonomy used in the regression included drainage class (PD, MWD, WD, SWED), clay or lamellae in subgroup, presence of saturated conditions in subgroup, oxides in subgroup, presence of fragipan, shallowest depth to bedrock $(\mathrm{cm})$, depth to high water table (m), surface run off class (rapid, high, medium, slow, low), potential for frost action (high, moderate, low), potential for seedling mortality (high, moderate, low), sugar maple site index, and drainage index from the U.S. Forest Service National Drainage Index (http://foresthealth.fs.usda.gov/soils/, accessed 12-1-12).

\subsection{Statistical Procedures}

Relationships between dieback, growth, foliage nutrient levels and soil nutrients were examined. The relationships between mean dieback and foliar characteristics were examined using multiple linear regressions with stepwise selection of non-forced variables and Pearson correlation coefficients. The RMRI and retranslocation efficacy was related to mineral soil $\mathrm{pH}$, foliage nutrients $(\mathrm{N}, \mathrm{P}, \mathrm{K}, \mathrm{Ca}, \mathrm{Mg}, \mathrm{Mn}, \mathrm{S}, \mathrm{Fe}, \mathrm{Al}, \mathrm{Ni}, \mathrm{Cu}$, 
$\mathrm{Zn}, \mathrm{B}, \mathrm{Na}, \mathrm{Cd}$, and $\mathrm{Pb}$ ), and mean plot earthworm impact ratings. Edaphic variables and dieback were also examined using stepwise regression. For investigating soil nutrients in plots exhibiting dieback, plots were grouped by percentage of dieback in the categories 19.9\%, 10-19.9\%, and 20-70\% (n=122 samples, 45 plots; 114 samples, 43 plots; 27 samples, 14 plots respectively).

The significance of differences in the mean annual BAI chronologies between foliar nutrient threshold and soil $\mathrm{pH}$ levels were tested using a repeated measure ANOVA. Tukey's procedure for all pairwise comparisons was used to compare ring data between categories $(\alpha=0.05)$. Linear regressions were used to evaluate the relationship between earthworm impact ratings, soil $\mathrm{pH}$, and the RMRI. Soil nutrients across horizons and dieback category were analyzed using log transformed data in a twoway factorial ANOVA. All statistical analyses were carried out using the software Statistix 9.1 (C1985-2008).

\section{Results}

\subsection{Foliar characteristics and dieback}

Mean foliage nutrient content was highly variable for many essential nutrients found in sugar maple trees in the study region. Many trees at many sites were near or below the published values for sugar maple nutrients in literature, or had levels exceeding the published range, suggesting toxicity or antagonistic interactions (Table 4.1). Frequency distributions of nutrient concentrations suggest that the majority of plots fall within normal ranges for healthy trees; with a few having exceedingly low or high values (Figure 4.1). The exception to this is $\mathrm{Na}$, with almost all plots having higher than reported values in literature. Concentrations of foliar $\mathrm{S}$ are all below the published ranges for sugar maple, consistent with the overall lower, and declining levels of deposition in the study area compared to eastern North America (Talhelm et al., 2012; NADP 2012).

There was a significant negative correlation between mean plot sugar maple dieback and foliar K (Pearson Correlation, $r=-0.205 ; \mathrm{p}=0.043), \mathrm{Cu}(\mathrm{r}=-0.263 ; \mathrm{p}=$ $0.008), \mathrm{Cd}(\mathrm{r}=-0.216 ; \mathrm{p}=0.032), \operatorname{Sr}(\mathrm{r}=-0.186 ; \mathrm{p}=0.067)$. The average leaf weight of 
the 10 randomly selected leaves was positively, significantly correlated with dieback $(\mathrm{r}=$ $0.295 ; \mathrm{p}=0.003$ ) (excluding one outlier plot with $>2 \mathrm{X}$ the level of average dieback).

The stepwise linear regression model with mean crown dieback and foliage characteristics retained four variables: $\mathrm{N}(\mathrm{p}=0.002), \mathrm{K}(\mathrm{p}=0.023), \mathrm{S}(\mathrm{p}<0.001)$, and mean leaf weight $(p=0.002)$. Mean leaf weight is significantly correlated with various foliar nutrients, soil $\mathrm{pH}$, mean leaf area, and earthworm impact ratings (Table 4.2). Leaf weight increased with increasing foliar $\mathrm{Mg}$, soil $\mathrm{pH}$, leaf area, earthworm impacts, and average dieback.

\subsection{Foliar characteristics and growth}

Thresholds for healthy sugar maple growth and crowns have been determined for some foliar nutrients in the eastern range of sugar maple $(\mathrm{Ca}>5500 \mathrm{mg} / \mathrm{kg} ; \mathrm{Mg}>700$ $\mathrm{mg} / \mathrm{kg}$; and $\mathrm{Mn}<1900 \mathrm{mg} / \mathrm{kg}$ ) (Horsley et al., 2000; Hallett et al., 2006, Long et al., 2009). Other nutrient thresholds are based on published values for healthy trees but may not have had fertility studies indicating specific threshold values. Different plots are below and exceeding threshold levels for different nutrients. Since 1940, mean BAI chronologies for plots with low foliar N, P, K, and Ca have been significantly different from plots with healthy foliar values for these nutrients $(p<0.001$ for all; Figure 4.2). The BAI's for P and K have been consistently lower for low levels while the BAI's for $\mathrm{N}$ and $\mathrm{Ca}$ have been more variable.

Since 1940, mean BAI chronologies stratified by low, sufficient, and high thresholds for secondary essential nutrients and nonessential foliar elements are also significantly different from each other ( $\mathrm{p}<0.001$; Figure $4.3 \mathrm{a}, 4.3 \mathrm{~b})$. Plots with deficient Mg have had significantly less basal area growth since 1940 (Figure 4.3a). Mean BAI chronologies for plots with the highest levels of $\mathrm{S}, \mathrm{Mn}, \mathrm{Fe}, \mathrm{Zn}, \mathrm{Cu}, \mathrm{Ni}, \mathrm{B}, \mathrm{Al}, \mathrm{Na}$, and $\mathrm{Cd}$ have all been consistently below plots with low to sufficient levels. For $\mathrm{Zn}, \mathrm{Cu}, \mathrm{B}$, and $\mathrm{Al}$, plots with the middle or sufficient threshold have had consistently more growth than plots with both excessive and low values of these elements, suggesting insufficient essential micronutrients in some areas. 
Correlation coefficients of the recent 5 year growth increments (RMRI) indicate significant relationships with several of the foliage nutrient variables (Table 4.3) (excluding outliers, exceedingly high values for $\mathrm{Pb}>40 \mathrm{mg} / \mathrm{kg}, \mathrm{Cd}>1 \mathrm{mg} / \mathrm{kg}, \mathrm{Zn}>100$ $\mathrm{mg} / \mathrm{kg}, \mathrm{Ni}>5 \mathrm{mg} / \mathrm{kg}, \mathrm{Cu}>25 \mathrm{mg} / \mathrm{kg}, \mathrm{Fe}>200 \mathrm{mg} / \mathrm{kg}, \mathrm{B}>100 \mathrm{mg} / \mathrm{kg}, \mathrm{Al}>60 \mathrm{mg} / \mathrm{kg}$ and $\mathrm{Mn}<3000 \mathrm{mg} / \mathrm{kg}$ ). Pearson correlation coefficient values can be lower with such large data sets, but significant positive relationships were determined between the RMRI and foliar $\mathrm{Zn}(\mathrm{p}=0.004)$ and $\mathrm{Cd}(\mathrm{p}=0.003)$ and negative relationships with $\mathrm{Ni}(\mathrm{p}=0.004)$, $\mathrm{Na}(\mathrm{p}=0.02)$, and $\mathrm{pH}(\mathrm{p}=0.005)$. Relationships between the RMRI and foliar $\mathrm{Cu}, \mathrm{B}$, and earthworm impact ratings were weaker, but approaching statistical significance $(\mathrm{p}<$ 0.1 ). The stepwise multiple regression model with the RMRI retained four foliar concentration variables: $\mathrm{Al}(\mathrm{p}=0.021), \mathrm{Fe}(\mathrm{p}=0.016), \mathrm{Cd}(\mathrm{p}=0.003)$, and $\mathrm{Ni}(\mathrm{p}=$ $0.001)$.

The negative relationship between mineral soil $\mathrm{pH}$ and RMRI is surprising (Figure 4.4) in that one would expect sugar maple growth to increase as $\mathrm{pH}$ approaches less acidic values that sugar maple is most commonly found on (Godman et al., 1990). Similarly, when BAI's are stratified by mineral soil $\mathrm{pH}$, the least acidic plots $(>4.6$ and $>$ $5.0 \mathrm{pH}$ ) have had lower mean BAI chronologies than more acidic soil sites (Figure 4.4).

\subsection{Foliar Retranslocation}

The percent change in foliar $\mathrm{Zn}$ is the only nutrient with a significant relationship with individual tree dieback values in 2009 (stepwise regression, $\mathrm{n}=89$ trees, $\mathrm{p}=0.046$ ). Trees with greater percent dieback had resorbed higher levels of August foliar Zn. No plot mean dieback values were significantly correlated with the average change in foliar nutrients.

Most micronutrients accumulated in foliage throughout the growing and autumn seasons with $\mathrm{N}, \mathrm{P}, \mathrm{K}, \mathrm{S}, \mathrm{Ni}$, and $\mathrm{Cu}$ being the only nutrients retranslocated (not correcting for leaf weight differences). Generally, very little $\mathrm{Cu}(<10 \%)$ was resorbed but a larger amount of $\mathrm{Ni}(23 \%)$ was also conserved. Foliar resorption or accretion of $\mathrm{N}, \mathrm{Mg}, \mathrm{K}$, and $\mathrm{Ca}$ are significantly correlated with their corresponding soil concentration (Table 4.4), stressing their importance to tree nutrition. For micronutrients, the majority decreased 
resorption as soil concentrations increased, though not significantly. The notable exceptions to this are $\mathrm{Mn}, \mathrm{Cd}$, and $\mathrm{Na}$. Maples resorbed less $\mathrm{K}, \mathrm{Mn}$, and $\mathrm{Cu}$ and more $\mathrm{Pb}$ on the lower $\mathrm{pH}$ soils. Earthworm impact ratings were also significantly correlated with the amount of foliar resorption of $\mathrm{P}$ and $\mathrm{Mn}$.

\subsection{Edaphic characteristics}

The majority of plots are on moderately to well drained spodzolic soils, with one inceptisol, and four alfisols in the Ottawa National Forest, all having been glaciated. Approximately $65 \%$ of plots $(\mathrm{n}=76)$ are located on soils commonly having fragipans or cemented layers between 18 and 40 inches, however, this was not measured in the field. Bedrock geology throughout the region is primarily made up of metamorphic and igneous rocks, mainly gneisses, shists, and sandstones. Soil textures were very sandy as $97 \%$ of plots sampled were greater than $50 \%$ sand.

Generally, foliar nutrients were weakly, though significantly correlated with their corresponding average soil concentration (Table 4.5). Foliar $\mathrm{Ca}, \mathrm{Mg}$, and $\mathrm{Al}$ are positively correlated with their soil elements as reported in literature (Park and Yanai, 2009), although correlations for $\mathrm{K}$ and $\mathrm{Mn}$ are the inverse. Foliar $\mathrm{Mn}$ is one of the least correlated with its soil counterpart, but it does appear to have a positive relationship. Soil chemistry varied considerably across horizons (Table 4.6).

The stepwise regression model for soils included mean soil nutrient concentrations, physical characteristics, and soil series information. The modeled relationship between mean sugar maple dieback and soil retained five variables: $\mathrm{Al}(\mathrm{p}<$ $0.001), \mathrm{Cu}(\mathrm{p}=0.007), \mathrm{Mg}(\mathrm{p}=0.002)$, mineral soil $\mathrm{pH}(\mathrm{p}<0.001)$, and earthworm impact rating $(\mathrm{p}=0.01)$.

The presence of earthworms in all models prompted further analysis of the earthworm impact rating and soil characteristics that increase the likelihood of their impact observation. A stepwise regression model of earthworm impact rating and soil characteristics (nutrient concentrations, physical variables, and series information) retained four variables: soil $\mathrm{Fe}$, particle size class, plot slope, $(\mathrm{p}<0.001$ for each) and soil $\mathrm{Ca} / \mathrm{Al}$ molar ratio $(\mathrm{p}=0.039)$. Evidence of earthworms increased as slope increased, 
likely an indication of some of the most heavily impacted areas being in the variably sloped terrain of the Keweenaw Peninsula and the Marquette Highland area of the U.P., MI and not truly reflective of preference. Earthworms were more likely to be found in less sandy soil.

Examination of soil nutrients by horizon indicates the variation in mineral concentration across depths (Table 4.6). Mean soil nutrients with significant differences across soil horizons included $\mathrm{K}, \mathrm{Ca}, \mathrm{Mg}, \mathrm{SO}_{4}{ }^{-} \mathrm{S}, \mathrm{Mn}, \mathrm{Ni}, \mathrm{Zn}, \mathrm{Na}, \mathrm{Al}, \mathrm{Cu}, \mathrm{Cd}$, and $\mathrm{Pb}(\mathrm{p}<$ 0.05 for each). Further evaluation across horizons by the category of sugar maple dieback indicates differences between plots that were not necessarily picked up by the regression models of dieback and mean nutrient contents in the top $30 \mathrm{~cm}$ (horizons $\mathrm{O}, \mathrm{A}, \mathrm{E}, \mathrm{B}$ ) (Figure 4.7). Soil nutrient across horizons with significant differences between dieback category included $\mathrm{Mg}(\mathrm{p}=0.021), \mathrm{Ni}(\mathrm{p}=0.019)$, and $\mathrm{Cd}(\mathrm{p}=0.009)$. No other nutrients had significant differences across soil horizons by dieback gradient.

\section{Discussion}

Cation depletion, mobilization of antagonistic ions, and soil acidification has been associated with poor forest health and growth in the northeastern U.S. (Likens et al., 1996; Markewitz et al,. 1998; Horsley et al., 2000; St. Clair et al., 2005; Schaberg et al., 2006; Bilodeau-Gauthier et al., 2011; and others). Mean foliar nutrient values for N, S, $\mathrm{P}, \mathrm{Ca}$, and $\mathrm{Mg}$ in stands with and without dieback were lower than baseline foliar values determined in similar plot locations in eastern Minnesota and northern Michigan in 1993 (Burton et al., 1993). Average foliar values determined for $\mathrm{Mn}, \mathrm{Al}, \mathrm{Fe}, \mathrm{B}, \mathrm{Zn}$, and $\mathrm{Cu}$, exceeded baseline foliar values reported values in the region as well.

Many foliar and soil samples had low $\mathrm{Ca}$ and elevated $\mathrm{Al}$ levels, which has historically been indicated in sugar maple dieback and decline in its eastern range. Several studies have indicated acidic deposition, biomass removal, and long-term decreases in exchangeable $\mathrm{Ca}$ as a valid explanation of this predisposition to decline in sugar maple forests (i.e. Kolb and McCormick 1993; Heisey 1995; Wilmot et al., 1995; Watmough et al., 1999; Adams et al., 2000; Horsley et al., 2000; Schaberg et al., 2006). Sugar maple's relationship between antagonistic acidic and base cation factions, 
especially $\mathrm{Ca} / \mathrm{Al}$ and $\mathrm{Mg} / \mathrm{Mn}$, is well documented (i.e. Long et al., 2009; BilodeauGautheir et al., 2011). Though $\mathrm{Ca}$ is not significant in models of dieback, the soil $\mathrm{Ca} / \mathrm{Al}$ ratio is less than $1: 1$ at $15 \%$ of plots. When this is the case, trees have a greater than $50 \%$ probability of adverse effects on growth (Cronon and Grigal 1995), as the Al is interfering cation uptake. Manganese and other minerals with negative correlations with leaf weight and dieback are likely also playing an antagonistic role in sugar maple nutrition if not exceeding critical levels. Elevated levels of trace elements signal soil development in mineralized parent material or contamination from an outside industrial source. Extremely high metal concentrations ( $\mathrm{Al}, \mathrm{Pb}, \mathrm{Cu}, \mathrm{Fe}, \mathrm{Ni}, \mathrm{Cd}, \mathrm{Cr}, \mathrm{Mn}$ ) for a few plots was noted. Greater levels of foliar and forest floor $\mathrm{Mn}, \mathrm{Cd}, \mathrm{Zn}, \mathrm{Cu}$, and $\mathrm{Pb}$ have been linked to higher maple decline ratings further east (Watmough 2010; BilodeauGauthier et al., 2011).

Since the 1980s, declining acidic deposition levels (NADP, 2012) have been related to decreased levels of sugar maple foliage concentrations of $\mathrm{S}, \mathrm{Ca}$, and $\mathrm{Al}$, though levels of $\mathrm{N}$ deposition is still $75 \%$ higher than needed for plant sequestration across the Upper Great Lakes Region (Talhelm et al., 2012). Stands in the western upper Great Lakes region are at the lowest end of a pollution gradient across the Midwest and Northeastern U.S. (Burton et al., 1993) though it still may be enough deposition to modify soil chemistry (Fenn et al., 1998). We did not measure deposition across the study range so we are unable to make authoritative statements about site level differences in deposition. However, even with decreasing deposition levels, forest ecosystem recovery will likely be on a decadal-long time scale due to the large amount of base cation leaching (Likens et al., 1996: Foster et al., 1989), and other depletions (Hedin et al., 1994; Schaberg et al., 2001).

Specific leaf weight (an indicator of leaf thickness) is generally lower for northern hardwood species on poor sites than on higher fertility sites (Jurik 1986). The negative correlations for nutrients may be due to the effects of sampling position on the trees (Morrison 1985) or soil perturbation. Alternatively, acute deficiencies or excessive nutrients at some sites that may produce thicker, leathery leaves. For example, a known symptom of B deficiency in plants is increased leaf thickness (Dell and Huang 1997). Leaves deficient in $\mathrm{K}$ also often appear dark green, thick and waxy, eventually curling 
along the edges and becoming chlorotic as the limitation becomes more pronounced (Bernier and Brazeau, 1988a). Little is known about the influence of deficient or excessive micronutrients on sugar maple foliage.

Some plots were near roads de-iced with road salt in the winter, but all plots were at least 200 feet from any road edge (excluding skid trails). The most common road deicing agent in the United States, including Michigan, is sodium chloride $(\mathrm{NaCl})$ due to its widespread availability and low cost (D'Itri, 1992; Michigan Department of Transportation, 1993). Foliar damage, dieback, and reduced growth have all been reported for urban and road-side sugar maples with increased $\mathrm{Na}$ levels (Dyer and Mader, 1986). Sodium can prohibit uptake of Ca, Mg, and K (Westing, 1966; Lynch et al., 1986) and potentially inhibit mycorrhizal uptake of nutrients (Spitko et al., 1978). The level of $\mathrm{Na}$ found in some leaves here are lower, but similar to trees near de-iced roads in Massachusetts (Bryson and Barker, 2006). Runoff could be bringing $\mathrm{Na}$ further into forest away from roads (Maltby et al., 1995).

The patterns of most nutrients across depths, especially $\mathrm{Ca}$ and $\mathrm{Al}$, generally follow reports in literature (Yanai et al., 2005). Sugar maple foliar chemistry has been shown to be best correlated across the entire depth of the B horizon (Bailey et al., 2004), which was deeper than sampled at some plots. The majority of sugar maple fine roots, however, are located in the top $10 \mathrm{~cm}$ of soil (Westing 1966). The $\mathrm{O}$ and A horizons are often poorly correlated with foliar nutrients due to the high variability and disturbances on the forest floor (Bailey et al., 2004).

The BAI trends for plots with below and above threshold levels for nutrients corroborate findings that generally tree growth is positively correlated with fractions of base cations and negatively correlated with metals and micronutrients (Bernier and Brazeau, 1988c; Bilodeau-Gauthier et al., 2010). The relationship between $\mathrm{pH}$ and growth is contrary to findings reported by Billodeau-Gauthier et al., (2010) who reported that growth generally decreased on more acidic soils. The influence may be explained by examining mineral soil $\mathrm{pH}$ and the mean earthworm impact rating. As $\mathrm{pH}$ increased, the forest floor condition rating worsened (1=high earthworm impacts, 5=no worm sign), reflecting earthworm avoidance of strongly acidic soils (Reich et al., 2005). Clearly some other factors besides soil $\mathrm{pH}$ alone are influencing growth. 
Retranslocation can be closely related to plant health and growth especially on nutrient poor soils (Ryan and Borman, 1982; May and Killingbeck, 1992). Calcium accumulation values in sugar maple foliage were much higher (more negative) than reported by Burton et al., (1993), possibly due to changing atmospheric and pedospheric chemistries. Retranslocation of $\mathrm{N}, \mathrm{P}, \mathrm{K}, \mathrm{Mg}$, and $\mathrm{S}$ were low compared to literature, with Mg still accumulating in October (Burton et al., 1993). According to Pregitzer et al., (1992), retranslocation (conservation) of foliar S should be higher, as deposition has decreased since the 1990's (Talhelm et al., 2012). A study in Quebec, measuring leaves across the growing season into October, found up to $30 \% \mathrm{Mg}$ resorption (Duchesne et al., 2001) much higher than values determined here. Similarly, sugar maple resorption rates for N, P, and $\mathrm{K}$ are lower in this study than in Quebec, by 20-30\% on average.

As evidence of earthworms increased, foliar resorption of $\mathrm{Mn}$ and $\mathrm{P}$ increased, suggesting that due to soil conditions conducive to worms or perturbations from their activity, trees are conserving more of these nutrients. Earthworms can have a dramatic impact on $\mathrm{P}$ cycling, intermixing the organic and mineral layers, increasing $\mathrm{P}$ fixation and P deficiencies (Paré and Bernier, 1989, Walbridge et al,. 1991). Other tree species have been shown to also increase their P resorption with low $\mathrm{P}$ availability, including other Acer species (Boerner, 1984; Côté and Dawson, 1991).

Models predict over $90 \%$ of sugar maple habitat will be invaded by earthworms within the next 100 years (Gundale et al., 2005). Stands on soils that are better buffered against deposition perturbation likely will support a larger density of earthworms. The interaction between nutrient imbalances, non-native earthworm invasion, climate variables, and anthropogenic inputs need to be further studied for sugar maple and other species.

\section{Conclusion}

Increased levels of dieback were significantly correlated with high or low foliar or soil concentrations of $\mathrm{N}, \mathrm{K}, \mathrm{Mg}, \mathrm{Al}, \mathrm{Cu}, \mathrm{Zn}, \mathrm{Cd}, \mathrm{S}, \mathrm{Sr}$, soil $\mathrm{pH}$, foliar weight, and earthworm impacts on the forest floor. Plots stratified by above or below foliar threshold levels of $\mathrm{Ca}, \mathrm{P}, \mathrm{N}, \mathrm{Cd}, \mathrm{B}, \mathrm{Na}, \mathrm{Ni}, \mathrm{Mn}, \mathrm{Cu}, \mathrm{Al}, \mathrm{Zn}, \mathrm{Fe}$, and $\mathrm{Pb}$ have had significantly 
different BAI chronologies since 1940. Soil biogeochemistry is likely predisposing or contributing to increased sugar maple dieback and reduced growth in stands across the western Upper Great Lakes region. Exotic earthworm invasion, anthropogenic deposition, and climate change impacts need to be holistically evaluated in the context of sugar maple health and nutrition. A closer look on a site by site basis would determine individual stand fertility and sugar maple health relationships for stand management.

\section{Acknowledgements}

This research was supported by GMO, LLC and the Forest Service Forest Health Monitoring Program. The foresters at American Forest Management, the U.S. Forest Service, and MI Department of Natural Resources were invaluable in their assistance in locating sugar maple stands with dieback. Michael Amacher, Forest Service, amiably performed foliar and soil nutrient analyses. Thanks to Chris Webster, Michigan Tech, for providing use of the tree ring reader. Andrew Burton, Michigan Tech, provided use of the leaf area measurer. We are also grateful to the field technicians that helped core trees and process samples: Sally Sanderson, Amy Berns, James Klapperich, Chad Fortin, Christine Jones, Melissa Porter, Donavon Young, Will Schultz, Eric Hollenbeck, Andrew Beebe, Sunshine Love, Alex Larsen, Kurt Lehman, and Jonathon Malette.

\section{References}

Adams, M.B., Berger, J.A., Jenkins, A.B., Zelazny, L. 2000. Impact of harvesting and atmospheric pollution on nutrient depletion of eastern US hardwood forests. For. Ecol Manage. 138: 301-319.

Allen, D.C., Molloy, A.W., Cooke, R.R., Lachance, D., Barnett, C. 1995. North American Maple Project: seven year report. USDA Forest Service, Radnor PA.

Allen, D.C., Molloy, A.W., Cooke, R.R., Pendrel, B.A., 1999. A ten-year regional assessment of sugar maple mortality In Horsley, S.B., Long, R.P. (eds) 1999. Sugar maple ecology and health: An international symposium. Warren, MI. June 2-4, 1998. USDA Forest Service Gen. Tech. Rep. NE-26. pp 27-45.

Auclair, A.D., Lill, J.T., Revenga, C. 1995. The role of climate variability and global warming in the dieback of northern hardwoods. Water Air Soil Poll. 91: 163-186.

Bailey, S.W., Horsley, S.B., Long, R.P., Hallett, R.A. 2004. Influence of edaphic factors on sugar maple nutrition and health on the Alleghany Plateau. Soil Sci. Am. J. 68: 243-252. 
Bernier, B., Brazeau, M. 1988a. Nutrient deficiency symptoms associated with sugar maple dieback and decline in the Quebec Appalachians. Can. J. For. Res. 18: 762767.

--- 1988b. Foliar nutrient status in relation to sugar maple dieback and decline in the Quebec Appalachians. Can. J. For. Res. 18: 754-761.

---1988c. Magnesium deficiency symptoms associated with sugar maple dieback in a Lower Laurentians site in southeastern Quebec. Can. J. For. Res. 18: 1265-1269.

Bernier, B., Pare, D., Brazeau, M. 1989. Natural stresses, nutrient imbalances and forest decline in southeastern Quebec. Water Air Soil Poll. 48: 239-250.

Bilodeau-Gauthier, S., Houle, D., Gagnon, C., Côté, B., Messier, C. 2011. Assessment of sugar maple tree growth in relation to the partitioning of elements in xylem along a soil acidity gradient. For. Ecol. Manage. 261: 95-104.

Boerner R.J. 1984. Foliar nutrient dynamics and nutrient use efficiency of four deciduous tree species in relation to site fertility. J. Appl. Ecol. 21: 1029-1040.

Bryson, G.M., Barker, A.V. 2002. Sodium accumulation in soils and plants along Massachusetts roadsides. Commun. Soil Sci. Plan. 33: 67-78.

Burton, A.J., Pregitzer, K.S., MacDonald, N.W. 1993. Foliar nutrients in sugar maple forests along a regional pollution-climate gradient. Soil Sci. Soc. Am. J. 57: 16191628.

Chandler, R.F. 1941. The amount and mineral nutrient content of freshly fallen leaf litter in the hardwood forests of central New York. J. Am. Soc. Agron. 33: 859-871.

Côté, B., Camiere, C. 1995. Application of leaf, soil, and tree ring chemistry to determine the nutritional status of sugar maple on sites of different levels of decline. Water Air Soil Poll. 83: 36-373.

Côté, B., Dawson, J.O. 1991. Autumnal allocation of phosphorus in black alder, eastern cottonwood and white basswood. Can. J. For. Res. 21: 217-221.

Côté, B., O’Halloran, I., Hendershot, W.H., Spankie, H. 1995. Possible interference of fertilization in the natural recovery of a declining sugar maple stand in southern Quebec. Plant Soil 168-169: 471-480.

Cronan, C.S., Grigal D.F. 1995. Use of calcium/aluminum rations as indicators of stress in forest ecosystems. J. Environ. Qual. 24: 209-226.

D'Itri, F.M. 1992. Chemical deicers and the environment. $1^{\text {st }}$ ed. Lewis Publishers, Boca Raton, FL. 621 pgs.

Dell, B., Huang, L. 1997. Physiological response of plants to low boron. Plant Soil 193: 103-120.

Drohan, P.J., Sharpe, W.E. 1997. Long-term changes in forest soil acidity in Pennsylvania, USA. Water Air Soil Pollut. 95: 299-311.

Drohan, P.J., Stout, S.L., Petersen, G.W. 2002. Sugar maple (Acer saccharum Marsh.) decline during 1979-1989 in northern Pennsylvania. For. Ecol. Manage. 170: 1-17.

Duchesne, L., Ouimet, R., Camiré, C., Houle, D. 2001. Seasonal nutrient transfers by foliar resorption, leaching, and litter fall in a northern hardwood forest at Lake Clair Watershed, Quebec, Canada. Can. J. For. Res. 31: 333-344.

Duchesne, L., Ouimet, R., Houle D. 2002. Basal area growth of sugar maple in relation to acid deposition, stand health, and soil nutrients. J. Environ. Qual. 31: 1676-1683.

Dyer, S.M., Mader, D.L. 1986. Declined urban sugar maples: growth patterns, nutritional status and site factors. J. Arboric. 12: 6-13. 
Ellesworth, D.S., Liu, X. 1994. Photosynthesis and canopy nutrition of four sugar maple forests on acid soils in northern Vermont. Can. J. For. Res. 24: 2118-2127.

Ellis, R.D. 1974. The seasonal pattern on nitrogen and carbon mineralization in forest and pasture soils in southern Ontario. Can. J. Soil Sci. 54: 15-28.

Fenn, M.E., Poth, M.A., Aber, J.D., Baron, J.S., Borman, B.T., Johnson, D.W., Lemly, A. D., McNulty, S.G., Ryan, D.F., Stottlemyer, R. 1998. Nitrogen excess in North American ecosystems: predisposing factors, ecosystem responses, and management strategies. Ecol. Appl. 8: 706-733.

Foster, N.W., Hazlett, P.W., Nicolson, J.A., Morrison, I.K. 1989. Ion leaching from a sugar maple forest in response to acidic deposition and nitrification. Water Air Soil Poll. 48: 251-261.

Foster, N.W., Mitchell, M.J., Morrison, I.K., Shepard, J.P. 1992. Cycling of acid and base cations in deciduous stands of Huntington Forest, New York, and Turkey Lakes, Ontario. Can. J. For. Res. 22: 167-174.

Godman, R.M., Yawney, H.W., Tubbs, C.H., 1990. Acer saccharum Marsh. Sugar Maple. Pages 78-91 In R.M. Burns, Honkala, B.H. (eds), Silvics of North America, Volume 2. Hardwoods. USDA Forest Service Agricultural Handbook 654. USDA Forest Service, Washington, D.C., USA.

Gosz, J. R., Likens, G.E., Bormann, F.E. 1972. Nutrient content of litter fall on the Hubbard Brook Experimental Forest, New Hampshire. Ecology 53: 769-784.

Gradowski, T., Thomas, S.C. 2006. Phosphorus limitation of sugar maple growth in central Ontario. For. Ecol. Manage. 226: 104-109.

Groffman, P.M., Driscoll, C.T., Fahey, T.J., Hardy, J.P., Fitzhugh R.S., Tierney G.L. 2001. Colder soils in a warmer world: A snow manipulation study in a northern hardwood forest ecosystem. Biogeochemistry. 56: 135-150.

Gundale, M.J., Jolly, W.M., Deluca, T.H. 2005. Susceptibility of a northern hardwood forest to exotic earthworm invasion. Conserv. Biol. 19: 1075-1083.

Hallett, R.A., Bailey, S.W., Horsley, S.B., Long, R.P. 2006. Influence of nutrition and stress on sugar maple at a regional scale. Can. J. For. Res. 36: 2235-2246.

Hedin L.O., Granat L., Likens, G.E., Buishand, T.A., Galloway, J.N., Butler, T.J., Rodhe, H. 1994. Steep declines in atmospheric base cations in regions of Europe and North America. Nature. 367: 351-354.

Heisey, R.M. 1995. Growth trends and nutritional status of sugar maple stands on the Appalachian plateau of Pennsylvania, U.S.A., Water Air Soil Poll. 82: 675-693.

Horsley, S.B., Long, R.P. (eds) 1999. Sugar maple ecology and health: An international symposium. Warren, MI. June 2-4, 1998. USDA Forest Service Gen. Tech. Rep. NE26.

Horsley, S.B., Long, R.P., Bailey, S.W., Hallett, R.A., Hall, T.J. 2000. Factors associated with the decline disease of sugar maple on the Allegheny Plateau. Can J. For. Res. 30: 1365-1378.

Houle, D., Tremblay, S., Ouimet, R. 2007. Foliar and wood chemistry of sugar maple along a gradient of soil acidity and stand health. Plant Soil 300: 173-183.

Houston. D.R.1981. Stress triggered tree diseases: the diebacks and declines. USDA Forest Service, Northeastern For. Exp. Station Rep. NE-INF- 41-81. 36 p.

Houston, D.R. 1987. Forest tree declines of past and present: current understanding. Can. J. Plant Pathol. 9: 349-360. 
Jurik, T.W. 1986. Temporal and spatial patterns of specific leaf weight in successional northern hardwood tree species. Amer. J. Bot. 73: 1083-1092.

Kocman, V., Peel, T.E., Tomlinson, G.H. 1991. Rapid analysis of macro and micro nutrients in leaves and vegetation by automated X-ray fluorescence spectrometry (a case study of an acid-rain affected forest). Commun. Soil Sci. Plant Anal. 22: 20632075.

Kogelmann, W.J., Sharpe, W.E. 2006. Soil acidity and manganese in declining and nondeclining sugar maple stands in Pennsylvania. J. Environ. Qual. 35: 433-441.

Kolb, T.E., McCormick, L.H. 1993. Etiology of a sugar maple decline in four Pennsylvania stands. Can. J. For. Res. 23: 2395-2402.

Lea, R., Tierson, W.C., Bickelhaupt, D.H., Leaf, A.L. 1980. Differential foliar responses of northern hardwoods to fertilization. Plant Soil 54: 419-439.

Lea, R., Leaf, A.L. 1979. Growth responses of northern hardwoods to fertilization. Forest Sci. 25: 597-604.

Leaf, A.L. 1973. Plant analysis as an aid in fertilizing forests. In: Soil testing and plant analysis. Edited by L.M. Walsh and J.D. Beaton. Soil Science Society of America, Madison, WI pp. 426-454.

Likens, G.E., Bormann, F.H. 1970. Chemical analysis of plant tissues from the Hubbard Brook ecosystem in New Hampshire. Yale Univ. Sch. For. Bull. 79: 1-25.

Likens, G.E., Driscoll, C.T., Buso, D.C. 1996. Long term effects of acid rain: response and recovery of a forest ecosystem. Science 272: 244-246.

Liu, X., Ellsworth, D.S., Tyree, M.T. 1997. Leaf nutrition and photosynthetic performance of sugar maple (Acer saccharum) in stands with contrasting health conditions. Tree Physiol. 17: 169-178.

Long, R.P., Horsley, S.B., Hallet, R.A., Bailey, S.W. 2009. Sugar maple growth in relation to nutrition and stress in the northeastern United States. Ecol. Appl. 19(6): 1454-1466.

Lorimer, C.G., Dahir, S.E., Singer, M.T. 1999. Frequency of partial and missing rings in Acer saccharum in relation to canopy position and growth rate. Plant Ecol. 143: 189202.

Lorimer, C.G., Frehlich, L.E. 1984. A simulation of equilibrium diameter distributions of sugar maple (Acer sacharrum) Bull. Torrey Bot. Club 111: 193-199.

Lozano, F.C., Huynh, K.D. 1989. Foliar diagnosis of sugar maple decline by DRIS. Commun. Soil Sci. Plant 20: 1895-1914.

Lynch, J., Cramer, G.R., Lāuchli, A. 1986. Salinity reduces membrane-associated calcium in corn root protoplasts. Plant Physiol. 83: 390-394.

McLaughlin, D.L., Linxon, S.N., Dimma, D.E., McIlveen, W.D. 1987. Sugar maple decline in Ontario. In: Hutchison, T.C., Meema, K.M., (eds), Effects of atmospheric pollutants on forests, wetlands, and agricultural ecosystems. Springer-Verlag, New York, pp. 101-116.

McLaughlin, D.L., Corrigan, D.E., McIlveen, W.D. 1992. Etiology of sugar maple decline at selected sites in Ontario (1984-1990). Ontario Ministry of the Environment, Toronto, ON, Canada.

Mader, D.L., Thompson, B.W. 1969. Foliar and soil nutrients in relation to sugar maple decline. Soil Sci. Amer. Proc. 33: 794-800. 
Maltby, L., Forrow, D.M., Boxall, A.A., Calow, P., Betton, C.I. 1995. The effects of motorway runoff on freshwater ecosystems: 1. Field study. Environ. Toxicol. Chem. 14: 1079-1092.

Manion, P.D. 1991. Tree disease concepts. Prentice-Hall, Englewood Cliffs, NJ.

Manion, P.D., Lachance, D. 1992. Forest decline concepts. American Phytopathological Society Press, Minneapolis, MN.

May, J.D,. Killingbeck, K.T. 1992. Effects of preventing nutrient resorption on plant fitness and foliar nutrient dynamics. Ecology 73: 1868-1878.

Markewitz, D., Richter, D.D., Allen, H.L., Urrego, J.B. 1998. Three decades of observed soil acidification in the Calhoun Experimental Forest: Has acid rain made a difference? Soil Sci. Soc. Am. J. 62: 1428-1439.

Michigan Department of Natural Resources and Environment, Forest Management Division, 2009 Michigan Forest Health Highlights. http://fhm.fs.fed.us/fhh/fhh_09/mi_fhh_09.pdf

Michigan Department of Natural Resources and Environment, Forest Management Division, 2010 Michigan Forest Health Highlights. http://fhm.fs.fed.us/fhh/fhh_10/mi_fhh_10.pdf

Michigan Department of Natural Resources and Environment, 2012. Forest Management Division, 2012 Michigan Forest Health Highlights http://www.midnr.com/Publications/pdfs/ForestsLandWater/ForestHealth/FHH.pdf

Michigan Department of Transportation, 1993. Current deicing practices and alternative deicing materials. In The use of selected deicing materials on Michigan Roads: Environmental and economic impacts. Public Sector Consultants, Inc., December 1993, pgs 13-57.

Millers, I., Shriner, D.S., Rizzo, D. 1989. History of hardwood decline in the Eastern United States. USDA Forest Service, Northeastern Forest Experiment Station, Gen. Tech. Rep. NE-126. Broomall, PA, 75 p.

Morrison, I.K. 1985. Effect of crown position on foliar concentrations of 11 elements in Acer saccharum and Betula alleghaniensis trees on a till soil. Can. J. For. Res. 15: 179-183.

National Atmospheric Deposition Program (NADP) 2012. National Trends Network, NADP Program Office, Champaign, IL, http://nadp.sws.uiuc.edu/ (accessed October 2012).

Ouimet, R., Camire, C., Furlan, V. 1995. Endomycorrhizal status of sugar maple in relation to tree decline and foliar, fine-roots, and soil chemistry in the Beauce region, Quebec. Can. J. Bot. 73: 1168-1175.

Pare, D., Bernier, B. 1989. Origin of the phosphorus deficiency observed in declining sugar maple stands in the Quebec Appalachians. Can. J. For. Res. 19: 24-34.

Park, B.B., Yanai, R.D. 2009. Nutrient concentrations in roots, leaves, and wood of seedling and mature sugar maple and American beech at two contrasting sites. For. Ecol. Manage. 258: 1153-1160.

Phillips, R.P., Yanai, R.D. 2004. The effects of $\mathrm{AlCl}_{3}$ additions on rhizosphere soil and fine root chemistry of sugar maple (Acer saccharum). Water Air Soil Poll. 159: 339356. 
Pilon, C.E., Côté, B., Fyles, J.W. 1994. Effect of snow removal on leaf water potential, soil moisture, leaf and soil nutrient status and leaf peroxidase activity of sugar maple. Plant Soil 162: 81-88.

Pilon, C.E., Côté, B., Fyles, J.W. 1996. Effect of an artificially induced drought and leaf peroxidase activity, mineral nutrition and growth of sugar maple. Plant Soil. 179: $151-158$.

Pregitzer, K.S., Burton, A.J., Mroz, G.D., Leighty, H. O., MacDonald, N.W. 1992. Foliar sulfur and nitrogen along an 800-km pollution gradient. Can. J. For. Res. 22: 17611769.

Reich, P.B., Oleksyn, J., Modryznski, J., Mrozinski, P., Hobbie, S.E., Eissesnstat, D.M., Chorover, J., Chadwick, O.A., Hale, C.M., Tjoelker, M.G. 2005. Linking litter calcium, earthworms and soil properties: a common garden test with 14 tree species. Ecol. Lett. 8: 811-818.

Ryan, D.F., Borman, F.H. 1982. Nutrient resorption in northern hardwood forests. BioScience 32: 29-32.

Sackett, T.E., Smith, S.M., Basiliiko, N. 2012. Exotic earthworm distribution in a mixeduse northern temperate forest region: influence of disturbance type, development age, and soils. Can. J. For. Res. 42: 375-381.

Schaberg, P.G., DeHayes, D.H., Hawley, G.J. 2001. Anthropogenic calcium depletion: a unique threat to forest ecosystem health? Ecosyst. Health 7: 214-228.

Schaberg, P.G., Tilley, J.W., Hawley, G.J., Dehayes, D.H., Bailey, S.W. 2006. Associations of calcium and aluminum with the growth and health of sugar maple trees in Vermont. For. Ecol. Manage. 223: 159-169.

Soil Survey Staff, Natural Resources Conservation Service, United States Department of Agriculture. Soil Survey Geographic (SSURGO) Database for counties in WI and MI. Available online at http://soildatamart.nrcs.usda.gov. (accessed 12/1/2012).

Spitko, R.A., Tattar, T.A., Rhode, R.A. 1978. Incidence and condition of vesiculararbuscular mycorrhizae infections in the roots of sugar maple in relation to maple decline. Can. J. For. Res. 8: 375-379.

St. Clair, S.B., Carlson, J.E., Lynch, J.P. 2005 Evidence for oxidative stress in sugar maple stands growing on acidic, nutrient imbalanced forest soils. Oecologia 145: 258269.

St Clair, S.B., Sharpe, W.E., Lynch, J.P. 2008. Key interactions between nutrient limitation and climatic factors in temperate forests: a synthesis of the sugar maple literature. Can. J. For. Res. 38: 401-414.

Talhelm, A.F., Pregitzer, K.S., Burton, A.J., Zak, D.R. 2012. Air pollution and the changing biogeochemistry of northern forests. Front. Ecol. Environ. 10: 181-185.

Walbridge, M., Richardson, C.J., Swank, W.T. 1991. Vertical distribution of biological and geochemical phosphorus sub-cycles in two southern Appalachian forest soils. Biogeochemistry 13: 61-85.

Watmough, S., Brydges, T., Hutchison, T. 1999. The tree-ring chemistry of declining sugar maple in central Ontario, Canada. Ambio 28: 613-618.

Watmough, S.A., 2010. Assessment of the potential role of metals in sugar maple (Acer saccharum Marsh) decline in Ontario, Canada. Plant Soil 332: 463-474.

Westing A.H. 1966. Sugar maple decline: an evaluation. J. Econ. Bot. 20: 196-212. 
Wilmot, T.R., Ellsworth D.S., Tyree, M.T. 1995. Relationships among crown condition, growth, and stand nutrition in seven northern Vermont sugarbushes. Can. J. For. Res. 25: 386-397.

Yanai, R.D., Phillips, R.P., Arthur, M.A., Siccama T.G. Hane, E.N. 2005. Spatial and temporal variation in calcium and aluminum in northern hardwood forest floors. Water Air Soil Poll. 160: 109-118. 
Table 4.1. Ranges of average sugar maple foliar nutrient content for 120 plots in Upper Michigan, northern Wisconsin, and eastern Minnesota and published foliar nutrient ranges for assumingly healthy sugar maple $\left(\mathrm{mg} \mathrm{kg}^{-1}\right)$.

\begin{tabular}{ccccc}
\hline \hline & \multicolumn{3}{c}{ Study Plots } & Published Ranges* \\
\hline $\mathrm{N}$ & Mean & Min. & Max. & \\
$\mathrm{P}$ & 16384 & 9796 & 21582 & $16000-27400$ \\
$\mathrm{~K}$ & 6085 & 3149 & 8615 & $570-2200$ \\
$\mathrm{Mg}$ & 1367 & 657 & 2290 & $700-4400$ \\
$\mathrm{Ca}$ & 9135 & 3783 & 14883 & $5000-21900$ \\
$\mathrm{~S}$ & 1363 & 814 & 2183 & $1900-2200$ \\
$\mathrm{Mn}$ & 1294 & 132 & 6658 & $467-1900$ \\
$\mathrm{Fe}$ & 80.5 & 30.4 & 390.2 & $59-130$ \\
$\mathrm{Ni}$ & 0.7 & 0.0 & 6.8 & \\
$\mathrm{Cu}$ & 6.5 & 1.9 & 38.2 & $3-10$ \\
$\mathrm{Zn}$ & 39.8 & 17.3 & 196.2 & $29-71$ \\
$\mathrm{~B}$ & 44.9 & 17.6 & 315.6 & $26-81$ \\
$\mathrm{Na}$ & 100.9 & 67.2 & 192.7 & $12-82$ \\
$\mathrm{Sr}$ & 48.3 & 16.2 & 329.0 & $9.7-79.6$ \\
$\mathrm{Ba}$ & 102.5 & 29.6 & 771.5 & \\
$\mathrm{Al}$ & 31.4 & 9.3 & 201.8 & $23-60$ \\
$\mathrm{Cr}$ & 2.0 & 0.5 & 14.9 & \\
$\mathrm{Cd}$ & 0.3 & 0.1 & 1.8 & $0.05-0.39$ \\
$\mathrm{~Pb}$ & 9.2 & 0.3 & 105.6 & $0.2-1.0$ \\
\hline
\end{tabular}

* Sources: Bernier and Brazeau 1988a and b; Burton et al., 1993; Chandler, 1941; Côté et al., 1995; Drohan et al., 2002; Ellis, 1974; Ellsworth and Liu, 1994; Gosz et al., 1972; Gradowski and Thomas, 2006; Hallett et al., 2006; Heisey 1995; Horsley et al., 2000; Houle et al., 2007; Kocman et al., 1991; Kolb and McCormick, 1993; Kogelman and Sharpe, 2006; Lea and Leaf 1979; Lea et al., 1980; Leaf, 1973; Liu et al., 1997; Likens and Bormann, 1970; Long et al., 2009; Mader and Thompson, 1969; McLauglin et al., 1987; Morrison, 1985; Ouimet et al., 1995; Pare and Bernier, 1989; Park and Yanai, 2009; Shaberg et al., 2006; Watmough et al., 1999; Watmough, 2010; Wilmot et al., 1995. 


\begin{tabular}{|c|c|c|}
\hline \multicolumn{3}{|c|}{$\begin{array}{l}\text { Table 4.2. Pearson correlation coefficients associated } \\
\text { probabilities of plot average sugar maple leaf weight } \\
\text { and selected plot characteristics and nutrient } \\
\text { concentrations }(\mathrm{mg} / \mathrm{kg}) \text { in the western Upper Great } \\
\text { Lakes Region. }\end{array}$} \\
\hline & $\mathrm{r}$ & $\mathrm{p}$ \\
\hline $\mathrm{N}$ & -0.018 & 0.858 \\
\hline $\mathbf{P}$ & -0.293 & 0.004 \\
\hline $\mathrm{K}$ & -0.161 & 0.114 \\
\hline $\mathrm{Mg}$ & 0.002 & 0.986 \\
\hline $\mathrm{Ca}$ & -0.312 & 0.002 \\
\hline $\mathbf{S}$ & -0.189 & 0.062 \\
\hline Mn & -0.292 & 0.004 \\
\hline $\mathbf{F e}$ & -0.201 & 0.047 \\
\hline $\mathrm{Ni}$ & -0.102 & 0.319 \\
\hline $\mathrm{Cu}$ & -0.167 & 0.100 \\
\hline $\mathbf{Z n}$ & -0.369 & $<0.001$ \\
\hline B & -0.267 & 0.008 \\
\hline $\mathbf{N a}$ & 0.286 & 0.004 \\
\hline $\mathbf{S r}$ & -0.349 & $<0.001$ \\
\hline $\mathbf{B a}$ & -0.436 & $<0.001$ \\
\hline Al & -0.209 & 0.039 \\
\hline $\mathrm{Cr}$ & -0.153 & 0.133 \\
\hline Cd & -0.448 & $<0.001$ \\
\hline $\mathrm{Pb}$ & -0.115 & 0.260 \\
\hline soil pH & 0.243 & 0.016 \\
\hline $\begin{array}{l}\text { earthworm } \\
\text { impact }\end{array}$ & -0.262 & 0.009 \\
\hline average dieback & 0.295 & 0.003 \\
\hline average leaf area & 0.690 & $<0.001$ \\
\hline
\end{tabular}

Note: Bold indicates significance $(\mathrm{p} \leq 0.05)$. 


\begin{tabular}{|c|c|c|c|c|c|c|c|c|c|}
\hline & $\mathrm{Fe}$ & growth & Al & $B$ & $\mathrm{Ca}$ & $\mathrm{Cd}$ & Cu & $\mathrm{K}$ & $\mathrm{Mo}$ \\
\hline Growth & -0.108 & & & & & & & & \\
\hline $\mathrm{Al}$ & 0.746 & 0.09 & & & & & & & \\
\hline B & 0.076 & 0.205 & 0.236 & & & & & & \\
\hline $\mathrm{Ca}$ & 0.029 & 0.128 & 0.008 & 0.539 & & & & & \\
\hline $\mathrm{Cd}$ & 0.165 & 0.3 & 0.136 & 0.288 & 0.479 & & & & \\
\hline $\mathrm{Cu}$ & 0.296 & -0.193 & 0.291 & 0.141 & -0.104 & 0.232 & & & \\
\hline K & 0.073 & -0.057 & -0.038 & 0.315 & 0.147 & 0.227 & 0.386 & & \\
\hline $\mathrm{Mg}$ & -0.12 & 0.112 & -0.09 & 0.448 & 0.654 & 0.204 & -0.128 & 0.028 & \\
\hline $\mathrm{Mn}$ & 0.302 & 0.162 & 0.394 & 0.122 & -0.1 & 0.509 & 0.363 & 0.068 & -0.166 \\
\hline $\mathrm{N}$ & 0.162 & 0.072 & 0.253 & 0.09 & -0.129 & 0.116 & 0.463 & 0.277 & 0.028 \\
\hline $\mathrm{Na}$ & -0.065 & -0.244 & -0.186 & -0.162 & -0.052 & -0.138 & 0.114 & 0.078 & 0.211 \\
\hline $\mathrm{Ni}$ & 0.309 & -0.295 & 0.277 & 0.096 & -0.081 & 0.1 & 0.418 & 0.206 & -0.045 \\
\hline $\mathrm{P}$ & 0.066 & 0.082 & 0.006 & 0.389 & 0.358 & 0.304 & 0.145 & 0.505 & 0.108 \\
\hline $\mathrm{Pb}$ & 0.238 & 0.076 & 0.285 & 0.15 & 0.059 & 0.125 & 0.026 & 0.04 & -0.153 \\
\hline $\mathrm{pH}$ & -0.18 & -0.288 & -0.317 & 0.026 & 0.281 & -0.311 & -0.12 & 0.126 & 0.311 \\
\hline $\mathrm{S}$ & 0.275 & -0.016 & 0.378 & 0.464 & 0.268 & 0.124 & 0.41 & 0.521 & 0.267 \\
\hline Worms & 0.095 & 0.187 & 0.188 & -0.17 & -0.32 & 0.073 & 0.28 & -0.048 & -0.305 \\
\hline $\mathrm{Zn}$ & 0.186 & 0.295 & 0.199 & 0.417 & 0.262 & 0.624 & 0.192 & 0.163 & 0.24 \\
\hline
\end{tabular}

Table 4.3 continued. Pearson Correlation coefficients for the relationships between average plot sugar maple foliar nutrient concentrations, average earthworm impact rating (worms), and recent average yearly diameter increment of dominant or co-dominant sugar maple trees in Upper Michigan, northern Wisconsin, and eastern Minnesota. Bold values indicate a significant relationship $(\mathrm{p} \leq 0.05)$ and italics represent approaching significant relationships $(\mathrm{p}<0.1)$.

\begin{tabular}{lrrrrrrrrr}
\hline \hline & \multicolumn{1}{c}{$\mathrm{Mn}$} & \multicolumn{1}{c}{$\mathrm{N}$} & $\mathrm{Na}$ & $\mathrm{Ni}$ & $\mathrm{P}$ & $\mathrm{Pb}$ & $\mathrm{pH}$ & $\mathrm{S}$ & worms \\
\cline { 2 - 9 } $\mathrm{N}$ & $\mathbf{0 . 2 9}$ & & & & & & & & \\
$\mathrm{Na}$ & -0.163 & $\mathbf{0 . 2 5 7}$ & & & & & & & \\
$\mathrm{Ni}$ & $\mathbf{0 . 2 3 8}$ & $\mathbf{0 . 2 4 7}$ & $\mathbf{0 . 3 0 4}$ & & & & & & \\
$\mathrm{P}$ & 0.274 & -0.089 & -0.276 & -0.011 & & & & & \\
$\mathrm{~Pb}$ & $\mathbf{0 . 2 9 4}$ & 0.076 & $\mathbf{- 0 . 2 6 1}$ & 0.05 & 0.068 & & & & \\
$\mathrm{pH}$ & $\mathbf{- 0 . 5 6 2}$ & -0.046 & $\mathbf{0 . 3 6}$ & 0.068 & -0.096 & -0.205 & & & \\
$\mathrm{~S}$ & 0.104 & $\mathbf{0 . 4 7 8}$ & -0.04 & 0.191 & $\mathbf{0 . 2 1 1}$ & $\mathbf{0 . 2 5 3}$ & 0.062 & & \\
Worms & $\mathbf{0 . 4 6 9}$ & 0.187 & $\mathbf{- 0 . 2 1 2}$ & -0.032 & 0.138 & 0.162 & $\mathbf{- 0 . 4 1 9}$ & -0.078 & \\
$\mathrm{Zn}$ & $\mathbf{0 . 5 0 6}$ & $\mathbf{0 . 2 4 3}$ & -0.067 & $\mathbf{0 . 2 7 1}$ & $\mathbf{0 . 2 5 7}$ & 0.016 & $\mathbf{- 0 . 2 9 5}$ & $\mathbf{0 . 2 7 7}$ & 0.192 \\
\hline
\end{tabular}


Table 4.4. Pearson correlation coefficients and associated probabilities of $\%$ retranslocation for the corresponding soil concentration or significant variables for nutrients ( $\mathrm{n}=30$ plot averages). Bold indicates significance $(\mathrm{p} \leq 0.05)$.

\begin{tabular}{|c|c|c|c|c|c|}
\hline nutrient & $\mathrm{r}$ & $\mathrm{p}$ & $\begin{array}{l}\text { significant } \\
\text { nutrient }\end{array}$ & $\mathrm{r}$ & $\mathrm{p}$ \\
\hline \multicolumn{6}{|c|}{ soil variable } \\
\hline $\mathbf{N}$ & 0.348 & 0.081 & \multicolumn{3}{|l|}{$\underline{\text { mineral soil } \mathrm{pH}}$} \\
\hline Mg & -0.507 & 0.008 & $\mathbf{K}$ & 0.516 & 0.007 \\
\hline $\mathbf{K}$ & 0.401 & 0.042 & Mn & 0.362 & 0.069 \\
\hline $\mathbf{C a}$ & -0.750 & $<0.001$ & $\mathbf{P b}$ & -0.402 & 0.042 \\
\hline $\mathrm{Cd}$ & 0.181 & 0.375 & $\mathbf{C u}$ & 0.541 & 0.004 \\
\hline $\mathrm{Al}$ & -0.265 & 0.191 & & & \\
\hline $\mathrm{S}$ & -0.055 & 0.788 & \multicolumn{3}{|c|}{ earthworm impact rating } \\
\hline Mn & 0.089 & 0.667 & $\mathbf{P}$ & -0.475 & 0.014 \\
\hline $\mathrm{Fe}$ & -0.286 & 0.157 & Mn & -0.439 & 0.025 \\
\hline $\mathrm{Zn}$ & -0.154 & 0.454 & & & \\
\hline $\mathrm{Ni}$ & -0.222 & 0.276 & & & \\
\hline $\mathrm{Na}$ & 0.178 & 0.383 & & & \\
\hline $\mathrm{Pb}$ & -0.037 & 0.858 & & & \\
\hline
\end{tabular}


Table 4.5. Pearson correlation coefficients of sugar maple foliar nutrient content with corresponding average soil concentration from 120 plots in the western Great Lakes Region. Bold indicates significance $(\alpha=0.05)$.

\begin{tabular}{lrr}
\hline \hline Nutrient & $\mathrm{r}$ & \multicolumn{1}{c}{$\mathrm{p}$} \\
\hline $\mathrm{N}$ & 0.105 & 0.287 \\
$\mathbf{C a}$ & $\mathbf{0 . 3 7 6}$ & $<\mathbf{0 . 0 0 1}$ \\
$\mathrm{K}$ & -0.107 & 0.276 \\
$\mathbf{M g}$ & $\mathbf{0 . 5 7 4}$ & $<\mathbf{0 . 0 0 1}$ \\
$\mathrm{Mn}$ & 0.058 & 0.558 \\
$\mathrm{Al}$ & $\mathbf{0 . 2 3 2}$ & $\mathbf{0 . 0 1 7}$ \\
$\mathbf{F e}$ & $\mathbf{0 . 1 9 9}$ & $\mathbf{0 . 0 4 1}$ \\
$\mathbf{C d}$ & $\mathbf{0 . 2 6 1}$ & $\mathbf{0 . 0 0 7}$ \\
$\mathbf{C u}$ & $\mathbf{0 . 4 8 5}$ & $<\mathbf{0 . 0 0 1}$ \\
$\mathrm{Ni}$ & 0.136 & 0.168 \\
$\mathbf{Z n}$ & $\mathbf{0 . 3 4 7}$ & $<\mathbf{0 . 0 0 1}$ \\
$\mathrm{S}\left(\mathrm{SO}_{4}{ }^{-}\right)$ & 0.143 & 0.145 \\
$\mathbf{N a}$ & $\mathbf{0 . 4 3 6}$ & $<\mathbf{0 . 0 0 1}$ \\
$\mathrm{Pb}$ & -0.021 & 0.831 \\
\hline
\end{tabular}


Table 4.6. Average plot soil cations and trace elements by sample horizon or depth from 120 sugar maple forest health plots in the western Upper Great Lakes Region (sampled 20092011). Means are not weighted by sample mass.

\begin{tabular}{|c|c|c|c|c|c|c|c|}
\hline \multirow[b]{2}{*}{ sample depth } & \multicolumn{5}{|c|}{ Exchangeable soil cations } & \multirow[b]{2}{*}{$\begin{array}{c}\mathrm{Ca} / \mathrm{Al} \\
\text { molar } \\
\text { ratio } \\
\end{array}$} & \multirow[b]{2}{*}{$\begin{array}{c}\text { ECEC } \\
(\mathrm{cmolc} / \mathrm{kg})\end{array}$} \\
\hline & $\begin{array}{c}\mathrm{Na} \\
(\mathrm{mg} / \mathrm{kg}) \\
\end{array}$ & $\begin{array}{c}\mathrm{K} \\
(\mathrm{mg} / \mathrm{kg})\end{array}$ & $\begin{array}{c}\mathrm{Mg} \\
(\mathrm{mg} / \mathrm{kg})\end{array}$ & $\begin{array}{c}\mathrm{Ca} \\
(\mathrm{mg} / \mathrm{kg})\end{array}$ & $\begin{array}{c}\mathrm{Al} \\
(\mathrm{mg} / \mathrm{kg}) \\
\end{array}$ & & \\
\hline O horizon & 14.43 & 157.23 & 117.4 & 980.62 & 98.6 & 48.02 & 7.42 \\
\hline A horizon & 23.11 & 63.37 & 34.7 & 245.48 & 189.2 & 1.35 & 3.88 \\
\hline E horizon & 5.58 & 51.13 & 31.85 & 208.68 & 93.74 & 4.31 & 2.5 \\
\hline B horizon & 10.7 & 251.12 & 166.64 & 1435.52 & 35.63 & 88.47 & 9.62 \\
\hline top $10 \mathrm{~cm}$ & 49.12 & 98.48 & 64.19 & 529.43 & 156.9 & 9.38 & 5.38 \\
\hline \multirow[t]{3}{*}{ mean } & 19.66 & 100.73 & 67.85 & 541.11 & 133.1 & 20.09 & 5.08 \\
\hline & \multicolumn{7}{|c|}{ Extractable trace elements \& sulphate } \\
\hline & $\begin{array}{c}\mathrm{Mn} \\
(\mathrm{mg} / \mathrm{kg})\end{array}$ & $\begin{array}{c}\mathrm{Fe} \\
(\mathrm{mg} / \mathrm{kg})\end{array}$ & $\begin{array}{c}\mathrm{Ni} \\
(\mathrm{mg} / \mathrm{kg})\end{array}$ & $\begin{array}{c}\mathrm{Cu} \\
(\mathrm{mg} / \mathrm{kg})\end{array}$ & $\begin{array}{c}\mathrm{Zn} \\
(\mathrm{mg} / \mathrm{kg})\end{array}$ & $\begin{array}{c}\mathrm{Cd} \\
(\mathrm{mg} / \mathrm{kg})\end{array}$ & $\begin{array}{c}\mathrm{Pb} \\
(\mathrm{mg} / \mathrm{kg})\end{array}$ \\
\hline O horizon & 60.06 & 8.91 & 1.51 & 0.06 & 5.96 & 1.31 & 0.82 \\
\hline A horizon & 7.49 & 11.97 & 0.87 & 0.03 & 1.64 & 1.04 & 0.11 \\
\hline E horizon & 9.48 & 8.48 & 1.19 & 0.33 & 2.4 & 1.24 & 0.32 \\
\hline B horizon & 115.37 & 2.51 & 1.01 & 0 & 4 & 0.16 & 1.06 \\
\hline top $10 \mathrm{~cm}$ & 26.96 & 10.33 & 0.47 & 0 & 0.59 & 0.1 & 0.3 \\
\hline mean & 30.23 & 9.81 & 1.09 & 0.09 & 3.08 & 1.02 & 0.43 \\
\hline sample depth & $\begin{array}{c}\mathrm{SO}_{4}-\mathrm{S} \\
(\mathrm{mg} / \mathrm{kg})\end{array}$ & & & & & & \\
\hline O horizon & 13.63 & & & & & & \\
\hline A horizon & 9.15 & & & & & & \\
\hline E horizon & 4.9 & & & & & & \\
\hline B horizon & 2.1 & & & & & & \\
\hline top $10 \mathrm{~cm}$ & 7.73 & & & & & & \\
\hline mean & 9.28 & & & & & & \\
\hline
\end{tabular}



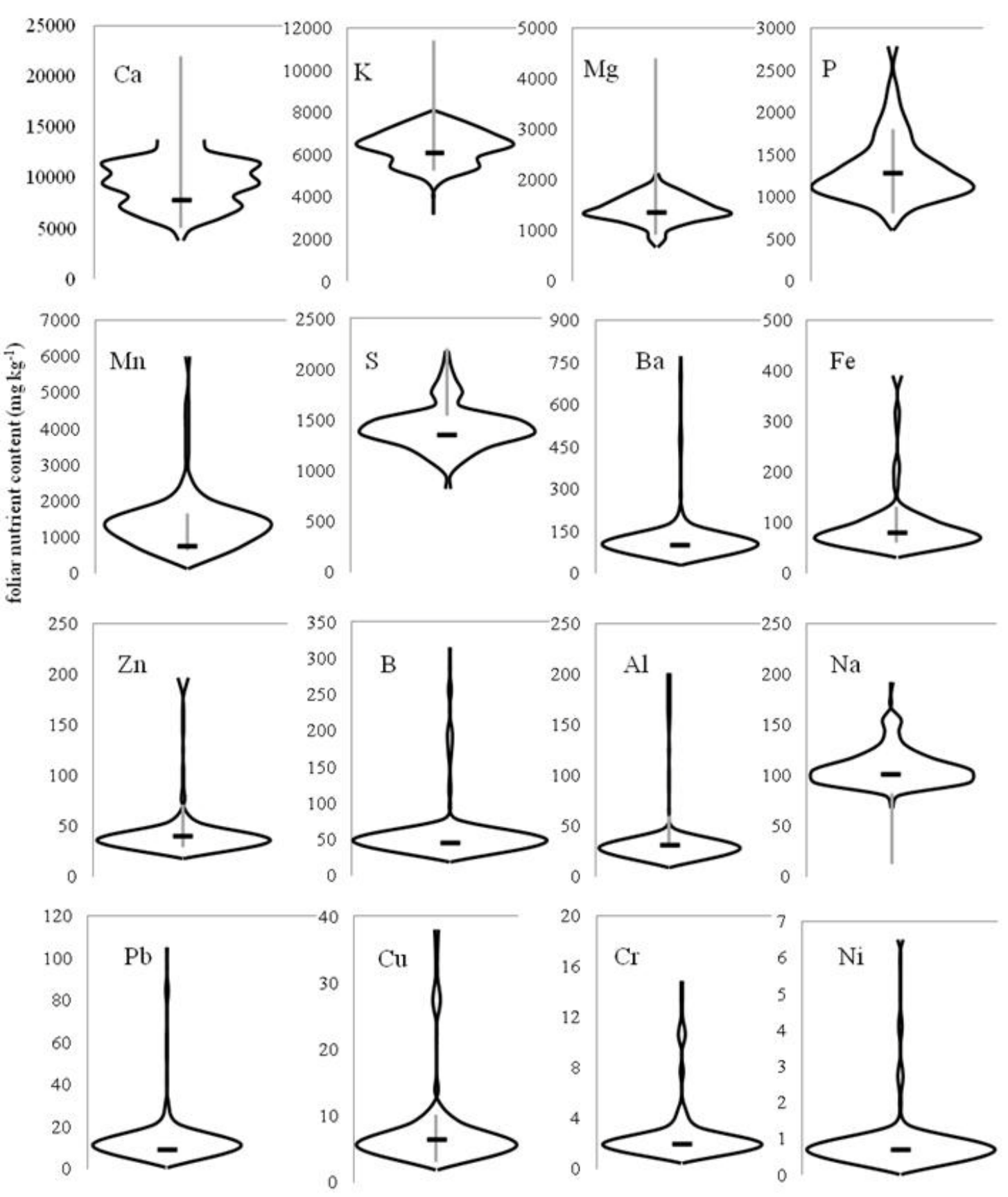

Figure 4.1. "Violin plots" of the ranges and relative distributions of sugar maple foliage nutrient levels in the western Great Lakes Region (120 plots, sampled 2009-2011). The wider and shorter the shape, the greater the relative frequency that foliar value was determined. The short horizontal line through the center of the shape is the mean sampled foliar level and the gray vertical bar represents the reported range found in sugar maple 
with little to no dieback in literature (Schaberg et al., 2006; Kolb and McCormick 1993; Mader and Thompson 1969; Ellis 1975; Lea et al., 1980; Morrison 1985; McLaughlin et al., 1987; Kocman et al., 1991; Bernier and Brazeau a, b, c; Watmough 2010). 


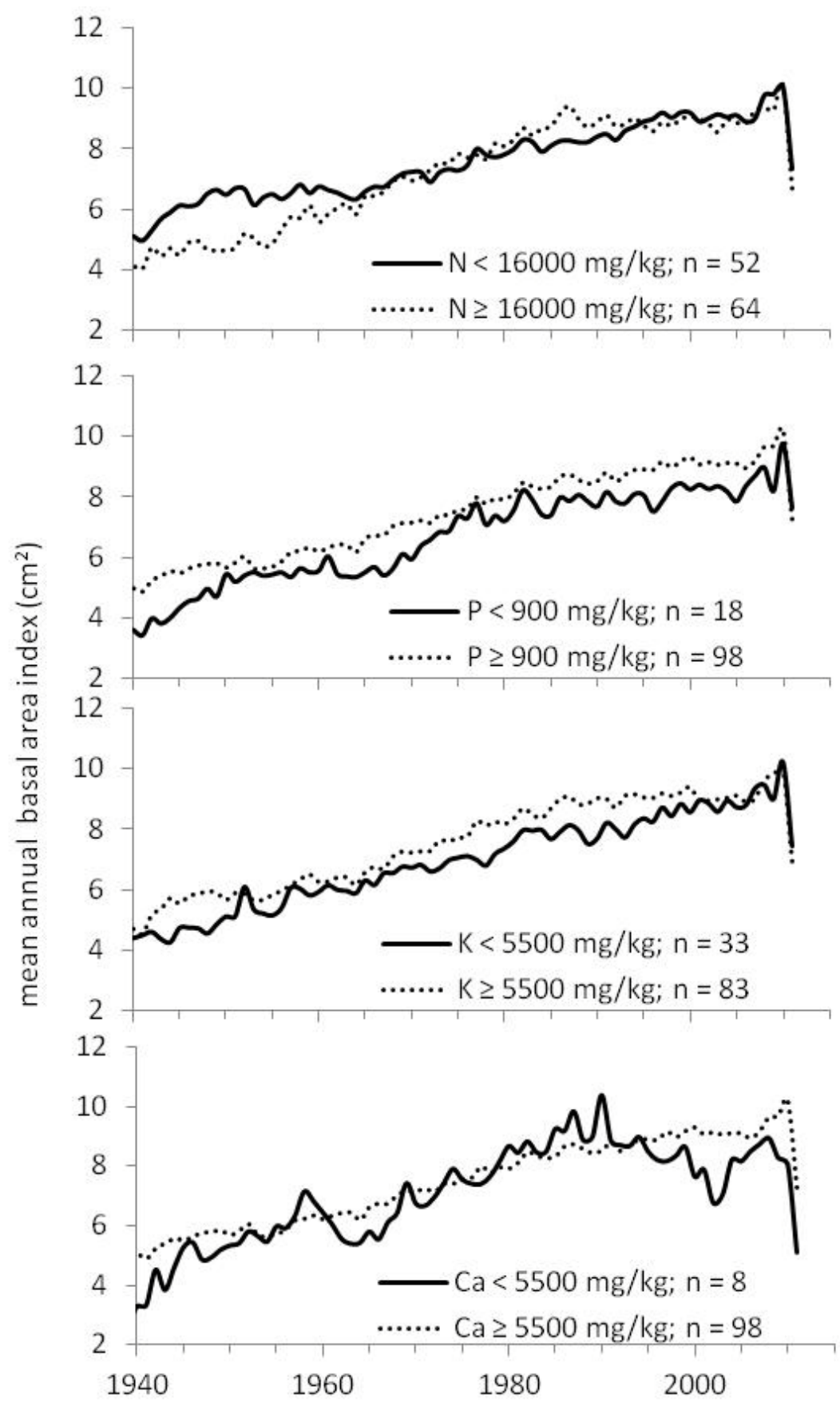

Figure 4.2. Mean sugar maple basal area increment chronologies and mean plot (n) foliage nutrient content from sugar maple health plots (sampled 2009-2011) in the western Upper Great Lakes region stratified by the critical threshold for foliar N, P, K, and Ca. All chronologies per nutrient are significantly different since 1940 ( $\mathrm{p}<0.001$; repeated measures ANOVA). 

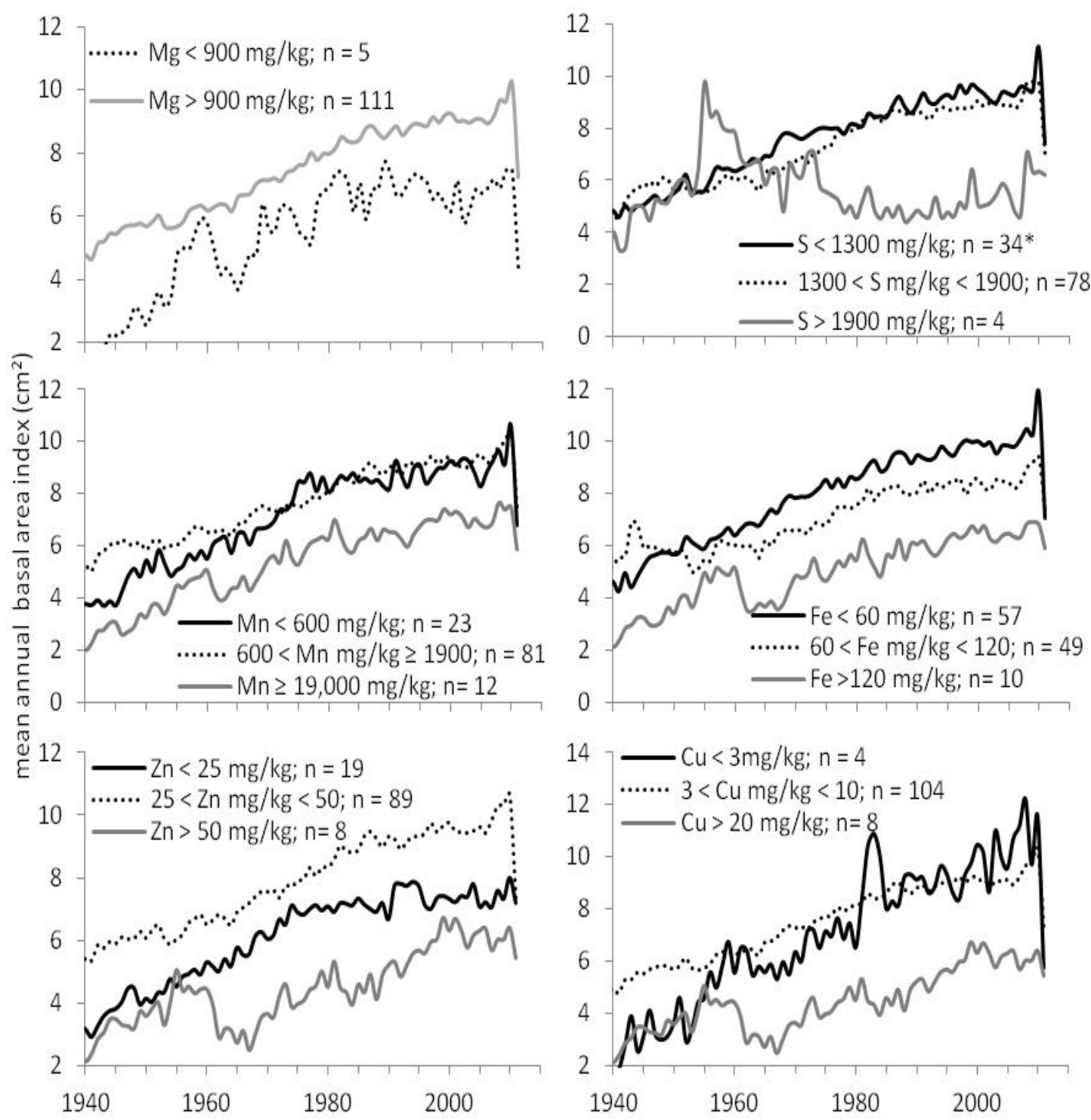

Figure 4.3a. Mean sugar maple basal area increment chronologies stratified by average plot (n) foliage nutrient content (sampled 2009-2011) from sugar maple health plots in the western Upper Great Lakes region separated by minimum and maximum thresholds in literature for mean values for foliar essential elements $\mathrm{Mg}, \mathrm{S}, \mathrm{Mn}, \mathrm{Fe}, \mathrm{Zn}$ and $\mathrm{Cu}$. All chronologies per nutrient are significantly different since $1940(\mathrm{p}<0.001$; repeated measures ANOVA followed by Tukey HSD test for all pair wise comparisons). * Only $\mathrm{S}$ $>1900 \mathrm{mg} / \mathrm{kg}$ significantly different from other S chronologies. 

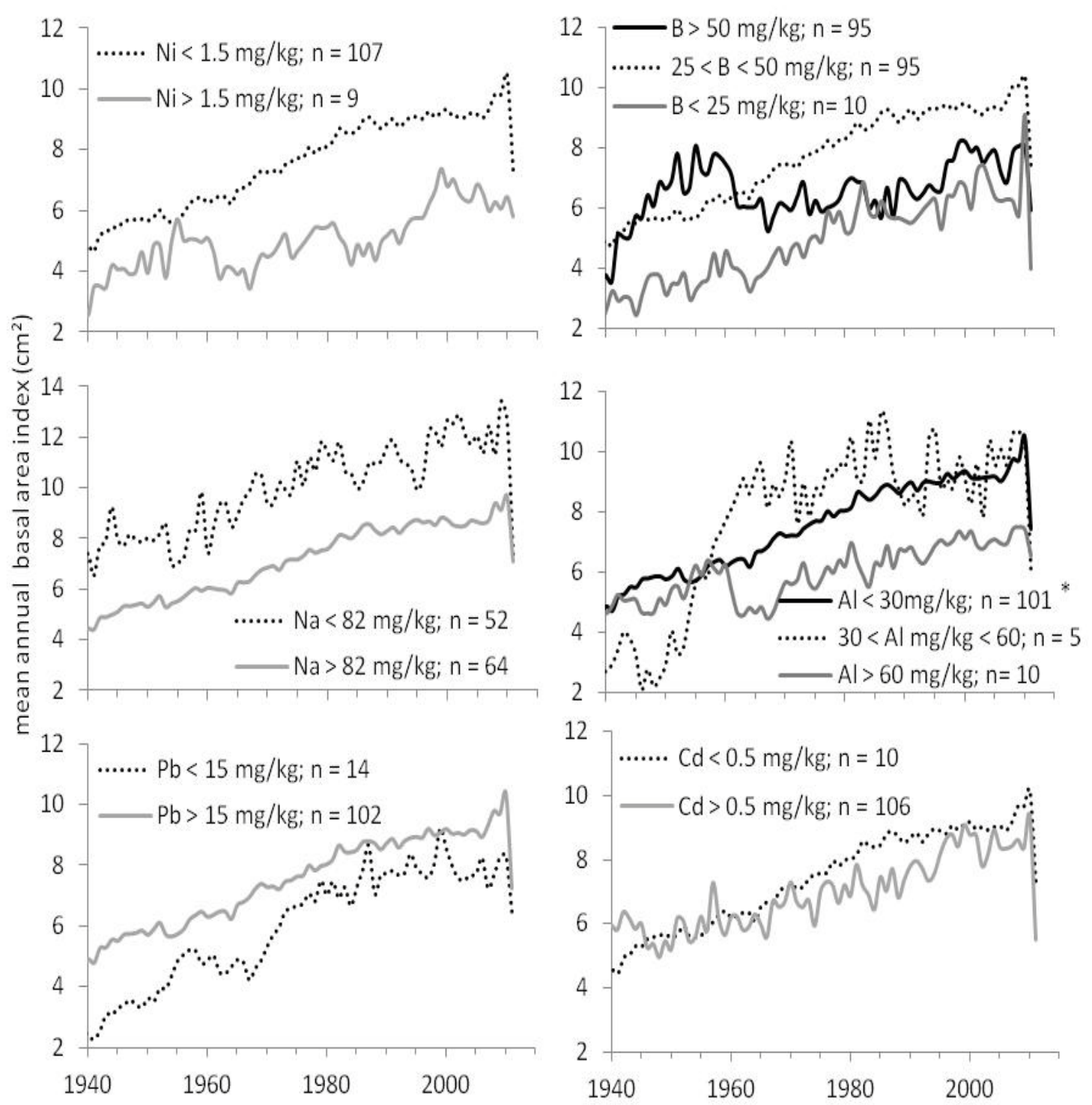

Figure 4.3b. Mean sugar maple basal area increment chronologies stratified by average plot (n) foliage nutrient content (sampled 2009-2011) from sugar maple health plots in the western Upper Great Lakes region separated by minimum and maximum thresholds in literature for mean values for foliar elements $\mathrm{Ni}, \mathrm{B}, \mathrm{Na}, \mathrm{Al}, \mathrm{Pb}$, and $\mathrm{Cd}$. All chronologies per nutrient are significantly different since $1940(\mathrm{p}<0.001$; repeated measures ANOVA followed by Tukey HSD test for all pair wise comparisons). * Only $\mathrm{Al}>60 \mathrm{mg} / \mathrm{kg}$ significantly different from other Al chronologies. 

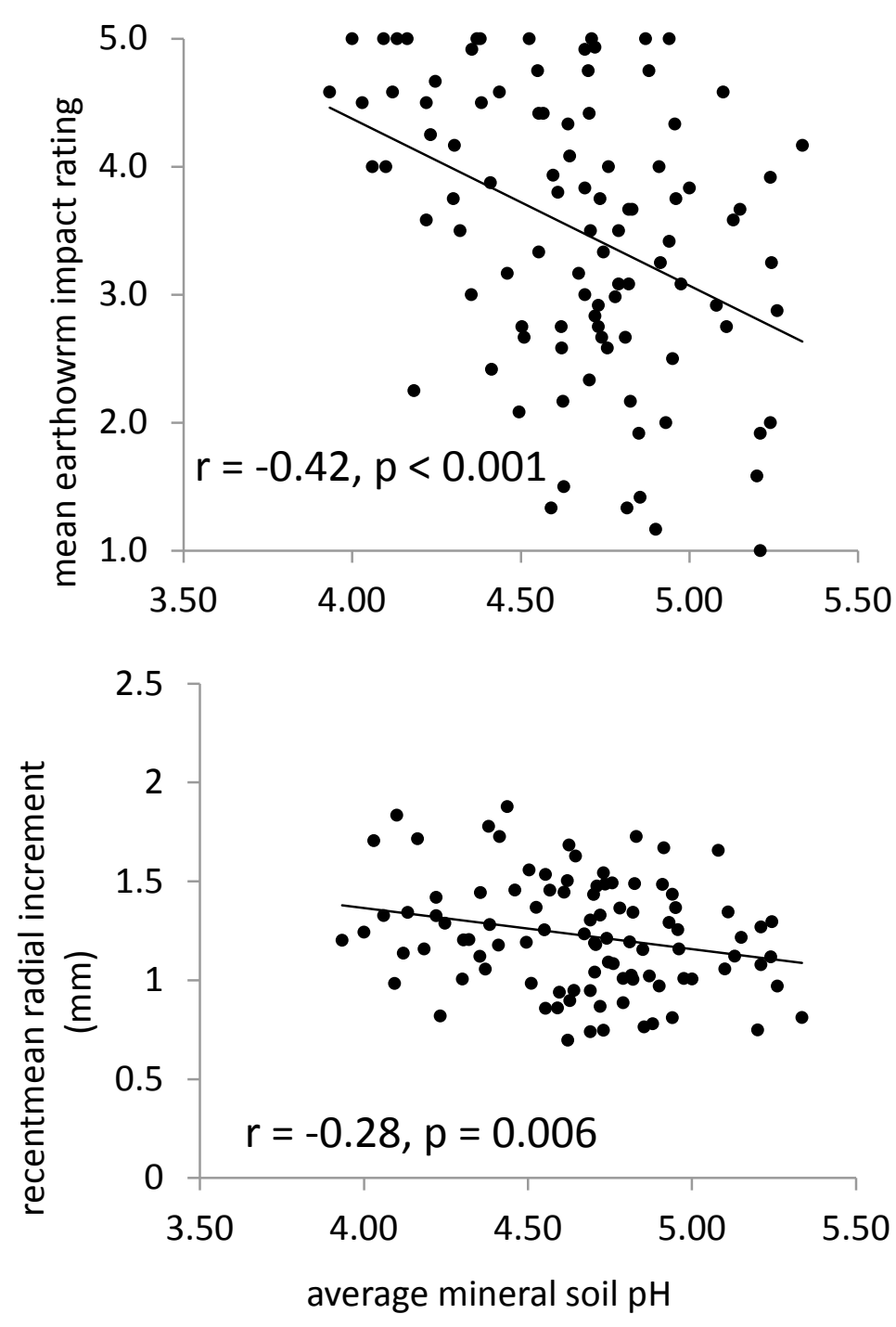

Figure 4.4. The relationships between mineral soil $\mathrm{pH}$, the mean earthworm impact rating, and recent mean radial increment (RMRI from 2003-2008) for sugar maple health evaluation plots in the western Upper Great Lakes Region. 


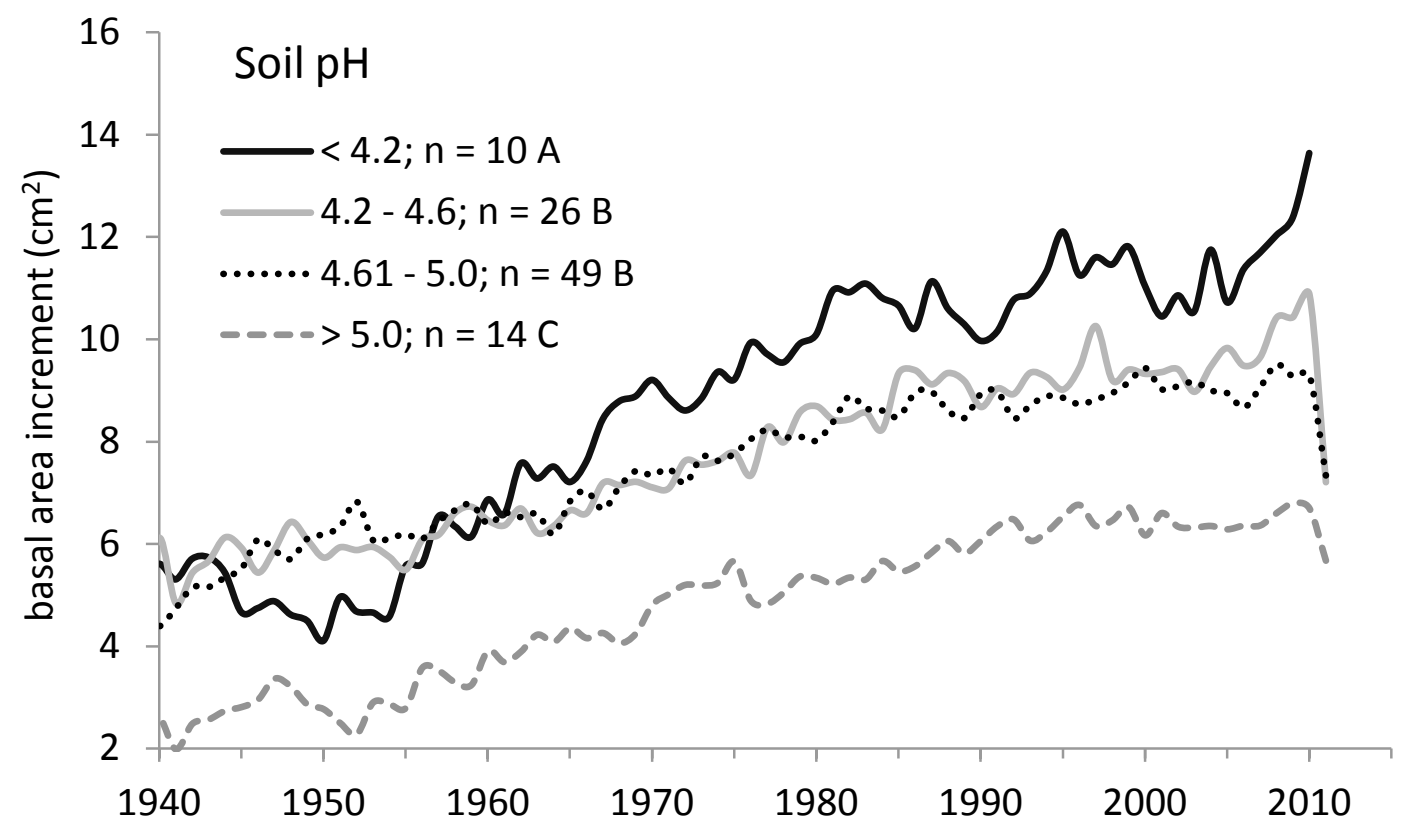

Figure 4.5. Mean sugar maple basal area increment stratified by mean plot (n) soil $\mathrm{pH}$ for sugar maple health plots in the western Upper Great Lakes Region (sampled 2009-2011). Letters indicate significant differences between BAI chronologies (repeated measures analysis, $\alpha=0.05$ ). 


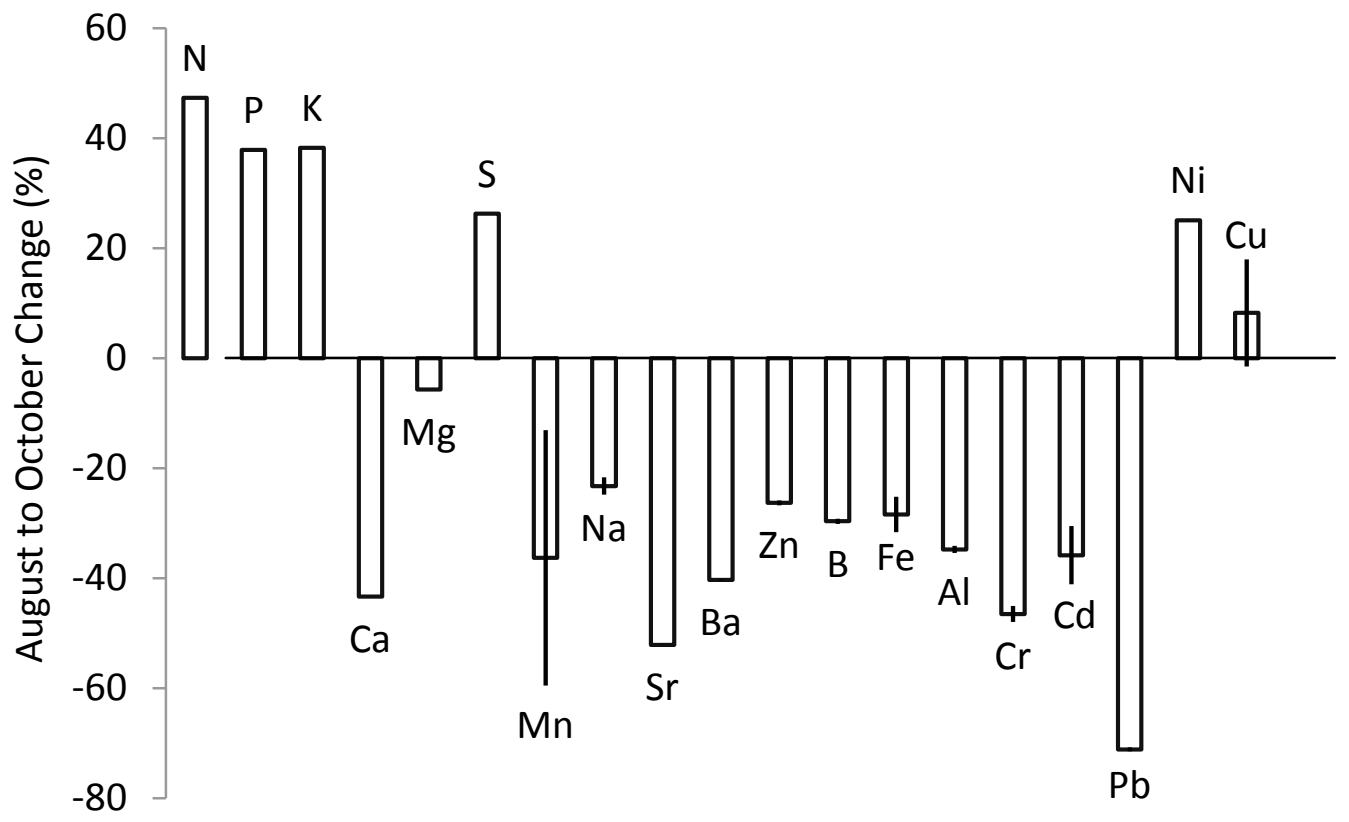

Figure 4.6. Percent change in sugar maple foliar nutrient resorption (+) or accretion (-) from August to October, 2009 across western Upper Michigan. Vertical lines represent standard error of the mean. 

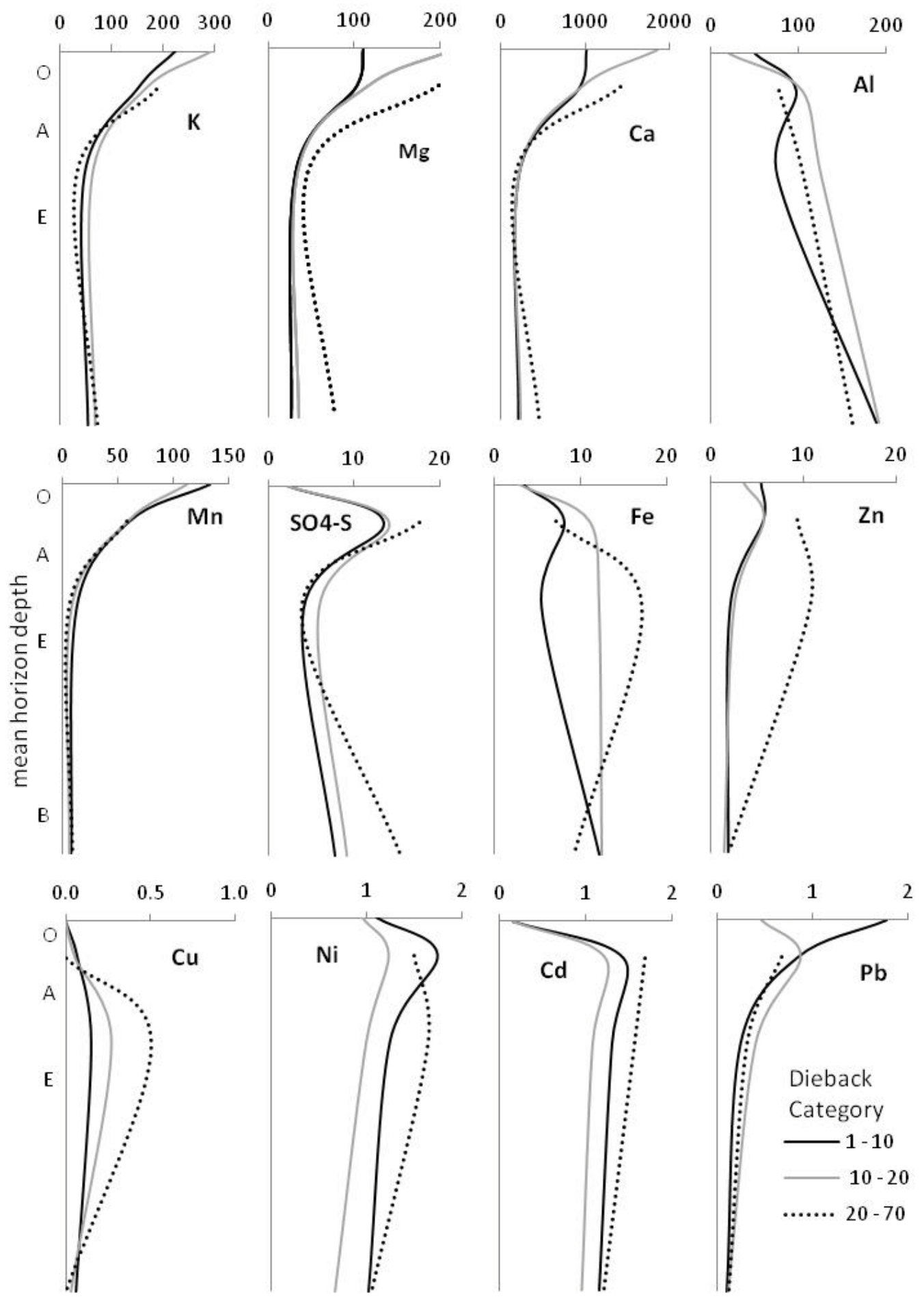

Figure 4.7. Soil nutrient concentrations ( $\mathrm{mg} / \mathrm{kg}$ ) for upper horizons, O, A, E, and B by mean sugar maple dieback plot percentages $(1-9.9 \%, 10-19.9 \%$, and $20-70 \%)$ in the western Upper Great Lakes region (sampled 2009-2011). Note: concentrations not weighted by sample mass. 


\section{Chapter 5 Preface}

The material in the following chapter is formatted for and was previously

published in The American Journal of Plant Sciences, 2012, 4(2A): 436-443 containing the title and author string. Data collection and analyses were completed by Tara L. Bal. Dana Richter provided the lab space, direction, and reviewing edits for the research. Andrew Storer and Martin Jurgensen provided comments and review for publication. Appendix B contains a copy of an emailed permission letter from the managing editor of The American Journal of Plant Sciences for use in this dissertation. 


\title{
Chapter 5
}

\section{The relationship of the sapstreak fungus, Ceratocystis virescens, to sugar maple dieback and decay in Northern Michigan $^{4}$}

\author{
Tara L. Bal, Dana L. Richter, Andrew J. Storer, and Martin F. Jurgensen \\ School of Forest Resources and Environmental Science, Michigan Technological \\ University, Houghton, USA
}

\begin{abstract}
Unusually high levels of dieback have recently been reported in sugar maple, Acer saccharum Marsh., in Upper Michigan, and a network of plots was established to determine the extent and factors associated with the dieback. A possible contributor to this dieback is sapstreak disease caused by Ceratocystis virescens (Davidson) Moreau. Unhealthy trees with considerable crown dieback were evaluated across the western Upper Peninsula, MI to determine the prevalence of the sapstreak fungus using a minimally destructive sampling technique. Approximately $8 \%$ of 90 trees sampled were sapstreak positive and approximately $10 \%$ of trees were positive at one site that had recently been harvested. While the high levels of maple dieback present in these forests appear not to be directly caused by widespread sapstreak disease, the occurrence of sapstreak may be significantly impacting trees at some locations. However, even when present on a low number of trees, the biointeraction of sapstreak and decay rates from other fungi could be important for future tree mortality and value to the forest industry. Therefore, the effect of two sapstreak fungal isolates on the amount of decay caused by two common maple white rot fungi, Trametes versicolor (L.:Fr.) Pilat. and Irpex lacteus (Fr.:Fr.) Fr. was tested in the laboratory. Sugar maple wood blocks were precolonized by two native isolates of $C$. virescens followed by inoculation and incubation with decay

\footnotetext{
The material contained in this chapter has been previously published in The American Journal of Plant
}

4 Sciences.
\end{abstract}


fungi. Mean percent weight loss of blocks by white rot decay fungi ranged from 39 to $55 \%$, but decay rates were not significantly affected by the presence of the sapstreak fungus.

\section{Introduction}

In Keweenaw, Houghton, Baraga, and Marquette Counties, Michigan, high levels of sugar maple dieback (ranging up to an average $>50 \%$ crown dieback in some stands) have recently been reported [1]. Records from the Upper Peninsula, MI indicate previous dieback episodes, yet the cause of many of these cycles has never been determined [2]. Sapstreak was proposed as a cause of dieback in the 1960's [3, 4]. In the past few decades, whenever dieback was observed the region, especially on industry land, sapstreak or poor management was assumed to be the cause. While it has not seemed to be as prominently reported in the area in recent years, pockets of sugar maple dieback in the Great Lakes area has been reported intermittently [2] therefore, the range, extent, and contributing factors to the current dieback were investigated in 2009 on private industry lands in western Upper Michigan. Since some of the heaviest dieback was found on industry lands, the question was raised about whether colonization by the sapstreak fungus (Ceratocystis virescens) introduced by harvesting wounds was a factor in this dieback [1].

\subsection{Sapstreak Characteristics and Biology}

Sapstreak is usually associated with logging wounds $[5,6,7,8]$. Most often, infected trees are found near logging roads, skid trails, or in sugarbushes along sap hauling roads [8]. In most forested settings, inoculum is apparently readily available, as shown by Shigo [9], who found $C$. virescens was one of the most common fungi in northern hardwood forests, occurring frequently as a saprophyte on fresh cut logs. This may mean that the fungus readily attacks trees already weakened. Ceratocystis virescens is known to occur as a pathogenic fungus to sugar maple and in another saprobic form of 
the species on other hardwoods that is less pathogenic and likely a separate mating population[10].

Trees infected with the sapstreak fungus typically exhibit high crown transparency, smaller than normal leaves, and eventually crown thinning and branch dieback (Figure 5.1, A and B) [11]. Some trees may be able to persist with no further symptom development for many years, while others continue crown dieback until death in as little as 1 to 2 years $[8,11]$.

Dark hyphae colonize the parenchyma and vessels and can readily be observed under a microscope differentiated from staining from other maple wood staining deposits but not from other fungi without perithecia (Figure 5.1C). In most trees, the fungus can spread and cause vascular staining throughout the roots and up the stem to 10-15 meters, (30-45 ft) [8], decreasing the value of lumber cut from the tree [12,13].

\subsection{Sapstreak and Wood Decay}

Investigators have noted that trees dying of sapstreak are frequently colonized at or near the roots by decay fungi, such as Amillaria sp., Xylaria sp., Hypoxylon deustum (Hoffm.) Grev. (Ustilina deusta (Hoffm.) Lind.), and Ganoderma applanatum (Pers.) Pat [5,11]. Mielke and Charrette [6] reported that all of the sapstreak-positive trees identified in their study were also infected with at least one of these fungi. Although the role of other fungi in the progression of sapstreak disease has not yet been demonstrated, decay and root rot fungi affect tree vigor, and possibly the rate of sapstreak disease progression. For example, a decay test with Ponderosa pine, (Pinus ponderosa Dougl ex. Laws.) showed that wood infected with an unknown blue-stain fungus had greater weight lost when decayed by a white rot fungus (11.6\%) and a brown rot fungus (13.3\%), as compared to wood blocks colonized by the two rot fungi alone (D. Richter, unpublished data). Therefore we hypothesized that the influence of sapstreak on decay rates of other fungi could be important for future tree mortality and value to the forest industry.

\subsection{Objectives}


The objectives of our study were to: 1) characterize the prevalence of sapstreak disease in sugar maple stands exhibiting dieback in Upper Michigan and 2) determine whether the presence of the sapstreak fungus affects the decay rate of commonly occurring white rot fungi on sugar maple wood blocks.

\section{Materials and Methods}

\subsection{Field sampling for the Sapstreak Fungus}

In 2009, private industry-owned sugar maple stands exhibiting varying amounts of dieback were identified in western Upper Michigan. A total of 30 sites were evaluated for the presence of sapstreak. Sites may have had old skid trails running through them but were at least 2 chains away from roadways and were selected based on the amount of sugar maple present (at least 10 trees within 0.04 hectare $>10.2 \mathrm{~cm}$ d.b.h.). Three sugar maples per site were sampled for the sapstreak disease. An attempt was made at each site to sample from three trees with varying levels of crown dieback, including a tree with a healthy crown or low dieback, a tree with an intermediate crown, and one with a higher level of dieback relative to the trees at the site. For example, in a relatively healthy stand $20 \%$ dieback of the crown may be one of the worst trees while in a relatively unhealthy stand, only $20 \%$ crown dieback may be one the best looking trees. The three sampled trees were of similar size, with no more than $2.5 \mathrm{~cm}$ difference in d.b.h. between them. Percent dieback in the crown was assessed using standard USFS Forest Health Monitoring Protocols that provides an ocular estimate of the percent of the crown that has died back as indicated by dieback with persisting fine branches in the upper and outer crown while ignoring old dead branches, large forks and shaded out epicormics under the crown [14]. Sites were visited again in 2010 to determine if crown conditions persisted.

Methods of detecting sapstreak are usually destructive in nature, chopping into the tree with an axe, boring, probing with a Shigometer, removing the whole tree, or tipping up the roots. At the base of each sugar maple tree, near a wound if visible, three sides of the base of the bole had a slice of bark and outer xylem wood (approximately $7.5 \mathrm{~cm} \mathrm{x}$ $12.5 \mathrm{~cm}$ ) was removed with a hatchet or chisel and hammer to look for discoloration 
indicating the presence of the fungus (Figure 5.1D). A similar technique has been used to determine the proportion of root-crown colonization by Ceratocystis wagneri (Goheen and Cobb), which causes black stain root disease in western conifers $[15,16]$. If no discoloration was present, tree sealant was placed on the wound and the tree was recorded as not infected. If discoloration was observed, a sapwood sample was removed, transferred to a plastic bag, and refrigerated at $4^{\circ} \mathrm{C}$ until isolations could be processed within a week. Isolation of $C$. virescens was attempted from discolored areas by aseptically removing small wood chips, placing them in $2 \%$ malt agar amended with Streptomycin at $200 \mathrm{ppm}$, and left to grow at room temperature $\left(20-22^{\circ} \mathrm{C}\right)$ for two weeks. Identification of $C$. virescens positive culture was based on hyphal and spore characters and the presence and size of black, long-necked perithecia compared to taxonomic descriptors and a side by side comparison with known cultures at $400 \mathrm{X}$ with a Nikon Optiphot ${ }^{\circledR}$.

A stand in Keweenaw County, MI, where the sapstreak fungus was collected from one of the three sample trees was further examined to determine the prevalence of sapstreak in the immediate area. The site was in close proximity to a recent harvest, and provided an opportunity for a more detailed sampling from residual stumps and trees, as well as from trees at the original site without needing to damage more than three trees in more valuable stands. An area approximately 0.4 hectares was thoroughly examined after approximately half of it was harvested in the fall of 2009 (within 2 months of entry). A previous harvest occurred around 10 years earlier. The original positive sapstreak sample was collected from the area not harvested in 2009. Sugar maples that had crown dieback or suspect crowns were the focus of our work, so there are a few (less than 10) apparently healthy trees around the perimeter of the area that were not investigated. Stumps from trees cut in late fall 2009, standing dead trees, and live trees with crown dieback symptoms were evaluated in May 2010 by cutting into the base on at least three sides of the bottom of the bole along the root collar and adjacent to wounds (if present) to look for the characteristic streaking caused by $C$. virescens. Dieback levels for live trees were recorded. The stumps still had relatively fresh wood when they were examined in spring 2010. Samples were processed as previously described. 


\subsection{Soil Block Decay Test}

A soil block test was used to determine the effect of the sapstreak fungus on wood decay by commonly-occurring white rot fungi found in sugar maple stands, Trametes versicolor and Irpex lacteus. A freshly-cut, disease free, sugar maple, $20 \mathrm{~cm}$ diameter was cut in February 2010 in Houghton County, Michigan to obtain 14x14x14 mm sugar maple sapwood blocks. Blocks were selected for uniformity and were free from defects. Two isolates of $C$. virescens were used for pre-colonization: A was found in the base of a living $26 \mathrm{~cm}$ diameter sugar maple tree in Keweenaw County, MI in August 2009 during this study, and B was obtained from a $30 \mathrm{~cm}$ sugar maple log cut in Houghton County, MI in September 2009 during a separate investigation. Colonies of both isolates were grown on $2 \%$ malt extract agar $(2 \mathrm{M})$ in deep $(100 \times 20 \mathrm{~mm})$ plates. Fresh cultures were important as much less vigorous growth has been noted with age, even after one year in culture [5]. After 5 days of growth at $20-22^{\circ} \mathrm{C}$, all plates were fully covered with dark mycelium. Isolate A was darker gray-green and denser than isolate B, however both exhibited rapid growth and produced abundant perithecia and ascospores.

A sterile plastic grid, approximately $3 \mathrm{~mm}$ mesh, was placed on top of the $C$. virescens mat in the petri dishes, and seven steam-sterilized (30 min) wood blocks were placed on the grid in each plate so that the cross-sectional face was in contact with the fungus. This was done to prevent uptake of agar nutrients by the blocks if placed directly on the agar. Wood blocks in three separate plates were precolonized by each $C$. virescens isolate. Plates and blocks were incubated for four weeks at $27^{\circ} \mathrm{C}$. By two weeks, $C$. virescens had grown very rapidly into all wood blocks and perithecia were present. Wood blocks were left for two additional weeks to ensure thorough internal colonization. At the end of incubation, a wood block colonized by each isolate was sectioned and examined microscopically (400x) to show that both isolates had colonized wood cells throughout the wood block (Figure 5.1C). Fungi were reisolated from the blocks to confirm the presence of $C$. virescens.

Precolonized and uncolonized sugar maple blocks were then dried overnight at $40^{\circ} \mathrm{C}$, labeled, and weighed to the nearest $0.01 \mathrm{~g}$ prior to insertion in soil jars. A simple 
viability test using $2 \mathrm{M}$ agar showed that $C$. virescens was still viable after oven drying overnight at $40^{\circ} \mathrm{C}$. The decay test used was based on AWPA E-10 "Standard Method of Testing Wood Preservatives by Laboratory Soil-block Cultures." [17]. Air-dried forest topsoil ( $100 \mathrm{~g}, \mathrm{pH} \sim 6.0$ ) was added to a square flint jar $(60 \mathrm{ml})$ with $30 \mathrm{ml}$ of distilled water. Jars were covered with a plastic lid with a $5 \mathrm{~mm}$ diameter hole covered with a strip of adhesive first-aid tape for ventilation and autoclaved for 30 minutes. Decay fungi used were Trametes versicolor MAD 697 and Irpex lacteus ATCC 11245. Pure culture techniques were conducted to confirm the identity of the inoculum at all stages in the test. Inocula for all fungi were grown on $2 \mathrm{M}$ agar for three weeks at $22^{\circ} \mathrm{C}$ prior to use in soil jars.

Wood blocks were steam sterilized for 30 minutes, before placing in soil test jars and inoculated with rot fungi. A piece of the agar-mycelium inoculum $(\sim 1 \times 2 \times 0.5 \mathrm{~cm})$ was placed on top of the soil in the jars and the block was placed firmly on the agar on top of the soil, making sure it was in good contact with the soil and inoculum. Identical methods were used for precolonized and non-colonized control blocks. Ten wood blocks were assigned to each treatment (Table 5.1). Lids were replaced tightly and jars were incubated at $27^{\circ} \pm 1^{\circ}, 85 \% \pm 5 \%$ relative humidity for 8 weeks. After eight weeks, blocks were removed from jars and the respective fungi were reisolated. Wood blocks were again dried overnight at $40^{\circ} \mathrm{C}$ and weighed to the nearest $0.01 \mathrm{~g}$.

Using a completely randomized ANOVA test in Statistix [18], multiple comparisons were made to determine whether significant differences in weight loss existed between sugar maple sapwood blocks decayed by a white rot fungus and sapstreak fungus, by only the sapstreak fungus, and by the white rot fungus alone.

\section{Results}

\subsection{Incidence of Sapstreak in Maple Stands}

Sugar maple stands sampled in 2009 had an average dieback value of $18.6 \%$, with values ranging from $1.8 \%$ to $77.8 \%$ (Figure 5.2) which was calculated for sugar maple by estimating each crown of all sugar maple trees greater than $10.2 \mathrm{~cm}$ d.b.h. within the 
randomly selected 0.04 hectare plot within the stand. Of the 90 trees sampled for sapstreak, seven had sapwood discoloration that was characteristic of infection by the sapstreak fungus. Five additional trees had a different type of discoloration that, after further sampling, was not associated with sapstreak. Twelve trees had some type of small $\left(\leq 250 \mathrm{~cm}^{2}\right)$ logging wound or other wound on the lower boles but none of these were sapstreak positive or suspect. None of the trees had sapstreak symptoms in more than one of the three exposed areas examined. Ceratocystis virescens was only isolated from one of the seven trees with characteristic sapwood discoloration. Subsequent revisits to the 30 plots have added to the likelihood that the six symptomatic trees had sapstreak (although isolation failed), as the level of dieback had increased from the previous year and other crown symptoms persisted.

Of the 90 trees sampled at 30 sites, $7.78 \% \pm 2.8 \%$ were considered to have sapstreak disease based on either crown symptoms and or isolation of the pathogen. The trees considered to have sapstreak had a wide range of crown dieback values (Table 5.2), and none of these trees had any visible wounds near the base. Trees with lower levels of dieback were also found to have sapwood discoloration at the base of the tree, suggesting early stages of infection. Over half of the symptomatic trees had the greatest amounts of crown dieback of the three trees sampled at each plot. More intensive sampling may have found more sapstreak positive cases, but this would require whole tree removal and/or root excavation which is expensive and undesirable.

\subsection{Incidence of sapstreak in a recently logged stand}

At the one stand where harvesting had recently occurred around a confirmed tree with $C$. virescens, other sugar maple trees and stumps were assessed for crown condition, sapwood discoloration, and the pathogen presence. The 32 trees examined had between 5 and $99 \%$ dieback, or were standing dead trees. Nine fresh sugar maple stumps were also examined. In addition to the original $C$. virescens infected tree, the characteristic streaking was found on two other live trees and in the base of one cut stump. Both live trees found with sapstreak had $>50 \%$ dieback, with one of them being very near the original sapstreak positive tree, and the other approximately $20 \mathrm{~m}$ away being surrounded 
by a mix of apparently healthy trees and trees with dieback. All trees with dieback were within three meters of different harvesting skid trails. Only one of the live trees was confirmed as $C$. virescens by laboratory isolation; however the other live tree and stump were symptomatic for sapstreak, as they had the characteristic streaking. Of the total live trees still standing, about one third had large, noticeable wounds near the base that could act as entry courts for the sapstreak fungus.

\subsection{Soil Block Decay Test}

Differences were evident in the growth rates on agar of the two $C$. virescens isolates prior to use in the soil block test, thus both isolates were tested to account for natural differences among individuals. Based on visual examination, all wood blocks treated with decay fungi appeared to be moderately to heavily colonized, and there were no apparent differences among blocks or between isolates. One individual block of the Trametes control group failed to colonize and was removed from the test.

Weight loss of maple blocks with white rot decay fungi ranged from $38.6 \%$ to $55.0 \%$ (Figure 5.3) with T. versicolor showing a significantly slower decay rate than $I$. lacteus blocks. Decay in blocks precolonized with $C$. virescens and $T$. versicolor was not significantly different from blocks colonized by only T. versicolor $(\mathrm{p} \leq 0.05)$. Decay in blocks precolonized with $C$. virescens and I. lacteus had less decay than I. lacteus alone, and this was significantly less $(\mathrm{p} \leq 0.05)$ for isolate B. The C. virescens precolonized wood blocks placed alone in soil jars also had weight losses (4.6\% and 4.7\%).

\section{Discussion}

With the large number of trees with dieback in the area, a correspondingly large amount of sapstreak might be expected if this disease was the direct cause [1]. Approximately $10 \%$ of the standing trees sampled intensively at one site in Keweenaw Co. had streaking characteristic of sapstreak although at least $80 \%$ of the trees in the area had symptoms of crown dieback. The total percentage of trees with sapstreak throughout the area is presumably slightly lower as some healthy trees with no dieback were not 
sampled. Another study in Upper Michigan to determine the prevalence of sapstreak in maple stands found infection rates as high as $9.8 \%$, (in 15 out of 153 trees in a selection cut area) [19]. Mielke and Charette [6] examined stands along major haul roads in Wisconsin and found $4.8 \%$ of trees infected with $C$. virescens, (21 out of 431 wounded sugar maples along major haul roads or skid trails) which approximated 1 tree per 0.9 hectares. In contrast, Kessler [20] only found five trees to have sapstreak in an entire seven hectare cut block examined in the Nicolet National Forest, WI. When the site in Keweenaw Co. was intensively examined and even larger pieces of bark were removed, the density of sapstreak infected trees was not found to be larger than any reported amounts in literature in recently logged areas of similar forest types.

In three of the four groups precolonized by $C$. virescens, weight loss from the decay fungi was reduced. In these cases, the sapstreak colonization may inhibit the activity of a decay fungus. In no cases was decay increased significantly. Variation in pathogenicity does exist between mating forms of $C$. virescens [10] but may also exist between individual isolates. The $\mathrm{pH}$ of uncolonized sugar maple wood is typically around 5.5, and sapstreak colonized wood is usually 8.5 or higher [5]. Growth of both isolates on citrate buffered agar was much more rapid than on the $2 \mathrm{M}$ agar and the difference in $\mathrm{pH}$ likely stimulated the growth on the citrate agar. The variance in $\mathrm{pH}$ of live trees and the effect of wounds on $\mathrm{pH}$ could be further examined in regards to the pathogenicity of the sapstreak fungus.

Stain fungi, like $C$. virescens, feed on the sugars and other carbohydrates in wood rather than the cellulose and lignin [21, 22]; thus they are not considered decay fungi. Staining alters the internal wood chemistry by utilizing wood extractives and free carbohydrates $[21,22]$. There is some indication that $C$. virescens produces volatiles that may stimulate growth of other fungi [23] and could remove sugars or solutes from the wood that may be used by decay fungi. Though many stain fungi are not typically considered pathogenic, their presence may weaken a tree sufficiently that other fungi colonize and cause decay [24, 25]. Further testing with other common decay fungi of sugar maple is required before further statements can be made about the possible effect of the sapstreak fungus on the decay of sugar maple wood. 
These results indicate that the role of sapstreak in wood decay and its biointeraction with other fungi is still not clear. This could partly be due to its various taxonomical name changes in literature $[26,27,5,28,29,30,31,32,33]$ and certainly, as molecular and genetic techniques are further employed, the taxonomy of Ceratocystis and other Ophiostomatoid fungi will continue to be clarified [34]. Regardless, the question of whether sapstain fungi affect wood properties and make wood more or less susceptible to subsequent decay requires further study [24]. In regards to the sugar maple dieback in the region, it is not solely caused by sapstreak, but most likely the result of a combination of biotic and abiotic factors with sapstreak disease being among them.

\section{Acknowledgements}

The authors thank GMO LLC. for providing funding for the field portion of this project. We also thank American Forest Management, Inc., Amy Berns, Sally Sanderson, Andrew Beebe, Eric Hollenbeck, James Klapperich and Chad Fortin for technical assistance in the field.

\section{References}

[1] Michigan Department of Natural Resources and Environment, Forest Management Division, "2009 Michigan Forest Health Highlights," 2009. http://fhm.fs.fed.us/fhh/fhh_09/mi fhh_09.pdf

[2] I. Millers, D. S. Shriner and D. Rizzo, "History of Hardwood Decline in the Eastern United States." General Technical Report NE-126. Broomall, PA: U.S. Department of Agriculture, Forest Service, Northeastern Forest Experiment Station, 1989, 75 p.

[3] K. Kessler, Jr. "Dieback of Managed, Old Growth Northern Hardwoods in Upper Michigan, 1954-1964-A case history.” Plant Disease Reporter Vol. 49, 1965, pp. 483-486.

[4] K. Kessler, Jr., "Dieback Not a Cause of Mortality or Reduction of Growth or Quality in Lake States Northern Hardwoods.” Journal of Forestry Vol. 65, No. 12, 1967, pp. 892-893.

[5] G. H. Hepting, "Sapstreak, a New Killing Disease of Sugar Maple.” Phytopathology Vol. 34, 1944, pp. 1069-1076. 
[6] M. E. Mielke and D. A. Charette, "The Incidence of Sapstreak Disease of Sugar Maple in Menominee County, Wisconsin, and Its Relationship to Wounds and Season of Logging." Northern Journal of Applied Forestry, Vol. 6, No. 2, 1989, pp. 65-67.

[7] D.R. Houston, "Importance of Buttress Root and Taphole Wounds as Infection Courts from the Sugar Maple (Acer saccharum) Sapstreak Pathogen, Ceratocystis coerulescens." Phytopathology Vol. 82, No. 2, 1992, p. 244.

[8] D.R. Houston, "Sapstreak Disease of Sugar Maple: Development Over Time and Space." Research Paper NE-687. Radnor, PA: U.S. Department of Agriculture, Forest Service, Northeastern Forest Experiment Station, 1993, 19 p.

[9] A. L. Shigo, "Observations on the Succession of Fungi on Hardwood Pulpwood Bolts.” Plant Disease Reporter, Vol. 46, 1962, pp. 379-380.

[10] T. C. Harrington, J. Steimel and G. A. Kile, "Genetic Variation in Three Ceratocystis Species with Outcrossing, Selfing and Asexual Reproductive Strategies.” European Journal of Forest Pathology, Vol. 28, No. 4, 1998, pp. 217-226. DOI: 10.1111/j.1439-0329.1998.tb01176.x

[11] D. R. Houston, "Recognizing and Managing Sapstreak Disease of Sugar Maple." Research Paper NE-675. Radnor, PA: U.S. Department of Agriculture, Forest Service, Northeastern Forest Experiment Station, 1993, 11 p.

[12] J. H. Ohman and A. B. Spike "Effect of Staining Caused by Sapstreak Disease on Sugar Maple Log and Lumber Values." Research Note NC-12. St. Paul, MN: U.S. Department of Agriculture, Forest Service, North Central Forest Experiment Station, 1966, $4 \mathrm{p}$.

[13] K. T. Smith "Sapstreak Disease and Biodeterioration of Sugar Maple." Biodeterioration Research, Vol. 3, 1990, pp. 303-310.

[14] U.S. Department of Agriculture, Forest Service, "Forest Health Monitoring 1999 Field Methods Guide." USDA Forest Service, National Forest Health Monitoring Program, Research Triangle Park, NC, 1999.

[15] D.J. Goheen and F.W. Cobb, "Infestation of Ceratocystis wagneri-Infected Ponderosa Pines by Bark Beetles (Coleoptra: Scolytidae) in the Central Sierra Nevada." The Canadian Entomologist, Vol. 112, No. 7, 1980, pp. 725-730.

[16] D.J. Goheen, F.W. Cobb, D. L. Wood and D.L. Rowney, "Visitation Frequencies of Some Insect Species on Ceratocystis wagneri Infected and Apparently Healthy Ponderosa Pines." The Canadian Entomologist, Vol. 117, 1985, pp. 1535-1543.

[17] American Wood-Preservers' Association (AWPA) "Standard Method of Testing Wood Preservatives by Laboratory Soil-Block Cultures." Standard E10-08. In: AWPA Book of Standards. AWPA, Birmingham, AL, 2008.

[18] Statistix ${ }^{\circledR} 8$ Analytical Software. User's Manual. Tallahassee, 2003 p. 396.

[19] J. H. Ohman and K. J. Kessler "Current Status of the Sapstreak Disease of Sugar Maple in the Lake States." Research Note LS-10. St. Paul, MN: U.S. Department of Agriculture, Forest Service, North Central Forest Experiment Station, 1963, 4 p. 
[20] K. Kessler Jr., "Sapstreak Disease of Sugar Maple Found in Wisconsin for the First Time." Research Note NC-140. St. Paul, MN: U.S. Department of Agriculture, Forest Service, North Central Forest Experiment Station, 1972, 2 p.

[21] A. D. M. Rayner and L. Boddy "Fungal Decomposition of Wood. Its Biology and Ecology." John Wiley and Sons: New York, 1998.

[22] R. A. Zabel and J. J. Morrell, "Wood Microbiology: Decay and its Prevention." Harcourt Brace Jovanovich, Academic Press, Inc: New York. 1992.

[23] P. M. Wargo and T. C. Harrington "Host Stress and Susceptibility." In: C. G. Shaw and G. A. Kile, Eds., Armillaria Root Disease. U.S. Department of Agriculture, Forest Service, Agriculture Handbook No. 691, Washington D.C., 1991, pp. 88101.

[24] K. A. Siefert, "Sapstain of Commercial Lumber by Species of Ophiostoma and Ceratocystis." In: M. J. Wingfield, K. A. Seifert, and J. F. Webber, Eds., Ceratocystis and Ophiostoma: Taxonomy, Ecology, and Pathogenicity. The American Phytopathological Society Press, St. Paul, MN, 1993, pp 141-151.

[25] J. N. Gibbs, "The Biology of Ophiostomatoid Fungi Causing Sapstain in Trees and Freshly Cut Logs. In: M. J. Wingfield, K. A. Seifert, and J. F. Webber, Eds., Ceratocystis and Ophiostoma: Taxonomy, Ecology, and Pathogenicity. The American Phytopathological Society Press, St. Paul, MN, 1993, pp 153-160.

[26] R. W. Davidson "Fungi Causing Stain in Logs and Lumber in the Southern States in Including Five New Species.” Journal of Agricultural Research, Vol. 50, 1935, pp. 589-807.

[27] R. W. Davidson, "Two American Hardwood Species of Endoconidiophora Described as New." Mycologia Vol. 36, 1944, pp. 300-306. doi: $10.2307 / 3754828$

[28] B. K. Bakshi, "Fungi Associated with Ambrosia Beetles in Great Britain." Transactions of the British Mycological Society, Vol. 33, 1950, pp. 111-120. doi:10.1016/S0007-1536(50)80054-2

[29] B. K. Bakshi, "Studies on Four Species of Ceratocystis, with a Discussion on Fungi Causing Sap-Stain in Britain.” Mycological Papers, Vol. 35, 1951, 16 pp.

[30] J. Hunt, "Taxonomy of the Genus Ceratocystis." Lloydia Vol. 19, 1956, pp. 1-59.

[31] T. R. Nag Raj and B. Kendrick, "A Monograph of Chalara and Allied Genera." Wilfrid Laurier University Press, Waterloo, Ontario, Canada. 1976, 200 p.

[32] H. P. Upadhyay, "A Monograph of Ceratocystis and Ceratocystiopsis.” University of Georgia Press, Athens, GA. 1981, 176 p.

[33] G. A. Kile and J. Walker, "Chalara australis, sp. nov. (Hyphomycetes), a Vascular Pathogen of Nothofagus cunnihamii (Fagaceae) in Australia and its Relationship to Other Chalara Species.” Australian Journal of Botany, Vol. 35, No. 1, 1987, pp. 1-32. doi:10.1071/BT9870001

[34] M. J. Wingfield, K. A. Seifert and J. F. Webber, Eds. "Ceratocystis and Ophiostoma: Taxonomy, Ecology, and Pathogenicity." The American Phytopathological Society Press, St. Paul, MN, 1993. 
Table 5.1. Design of soil block decay test of sugar maple (Acer saccharum) sapwood blocks precolonized with $C$. virescens isolates and also T. versicolor and I. lacteus. Numbers represent replicate wood blocks exposed to fungi in soil block test.

\begin{tabular}{c|cccc}
\hline \multirow{2}{*}{$\begin{array}{c}\text { First } \\
\text { Colonizers }\end{array}$} & \multicolumn{4}{|c}{ Second Colonizers } \\
\cline { 2 - 4 } & T. versicolor & I. lacteus & C. v. & C. v. \\
\hline none & 10 & 10 & 10 & B \\
C. v. isolate A & 10 & 10 & - & - \\
C. v. isolate B & 10 & 10 & - & - \\
\hline
\end{tabular}


Table 5.2. Crown dieback of sugar maple trees found with characteristic $C$. virescens streaking at seven locations in the western Upper Peninsula of Michigan. Letters indicate Houghton, Keweenaw, or Baraga Counties. Bold indicates characteristic streaking present. $\uparrow$ indicates the only lab confirmed sample.

\begin{tabular}{|c|c|c|c|c|}
\hline \multirow[b]{2}{*}{ Site Name } & \multicolumn{3}{|c|}{$\begin{array}{c}\text { \% Dieback of } 3 \text { trees checked for } \\
\text { sapstreak in } 2009\end{array}$} & \multirow{2}{*}{$\begin{array}{c}\% \text { Dieback of } \\
\text { sapstreak } \\
\text { tree in } 2010\end{array}$} \\
\hline & Low & Medium & High & \\
\hline Medora - K & 18 & 35 & 65 & 80 \\
\hline Snowgauge - K & 5 & 8 & $55 \dagger$ & 90 \\
\hline Mohawk-Gay - K & 1 & 6 & 18 & 3 \\
\hline North $-\mathrm{H}$ & 5 & 10 & 60 & 70 \\
\hline Gas Plant - H & 5 & 10 & 65 & 18 \\
\hline Rhode Island - H & 6 & 25 & 60 & 4 \\
\hline Camp 10 - B & 6 & 10 & 25 & 6 \\
\hline
\end{tabular}



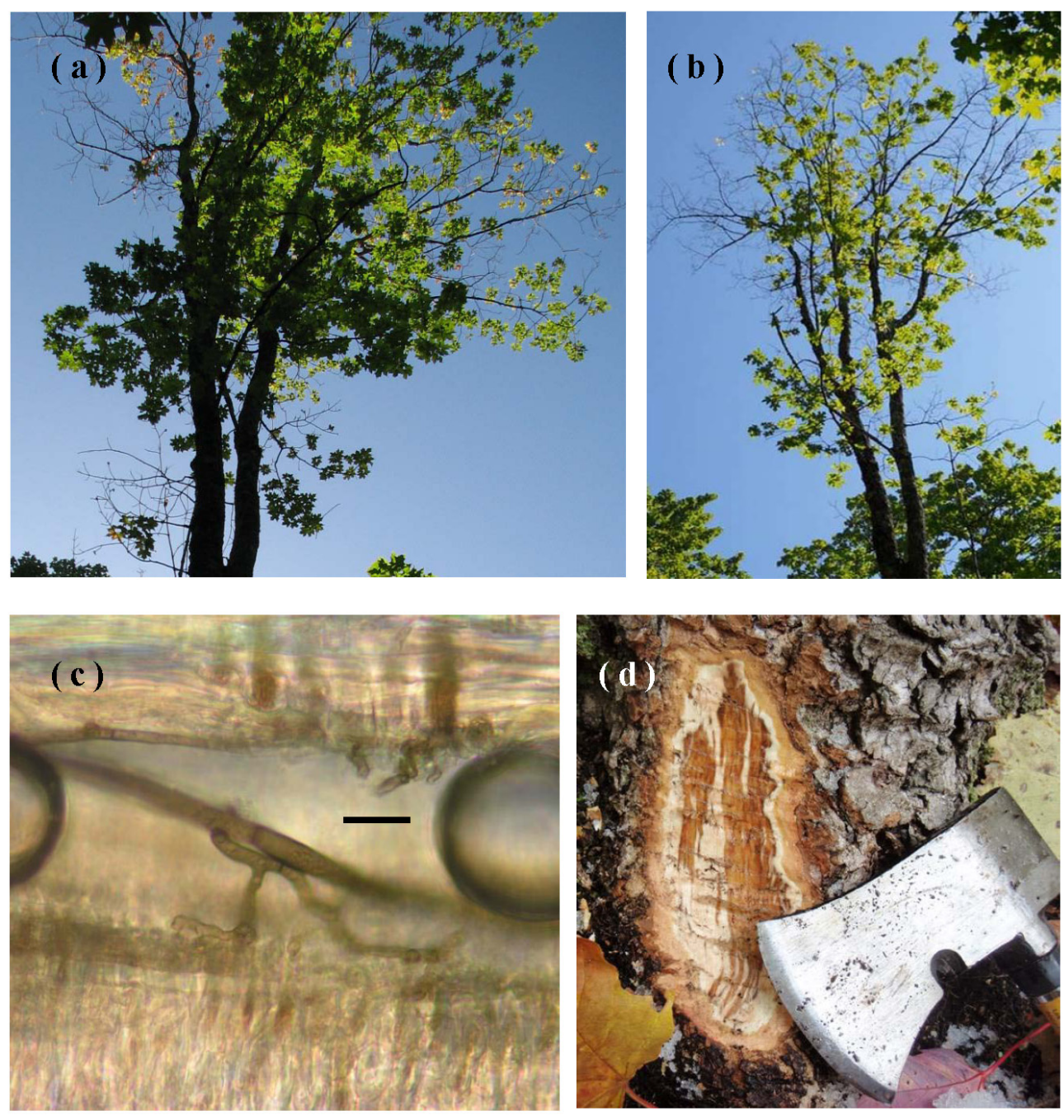

Figure 5.1. Characteristics of sapstreak disease: (a) In 2009, the crown of the sugar maple in Keweenaw Co., MI from which $C$. virescens isolate A was obtained, exhibited extensive dieback, high foliage transparency, and smaller leaves; (b) In 2010 dieback had progressed further; (c) $C$. virescens hyphae in a vessel in dark stained sugar maple wood (bar $=10 \mu \mathrm{m}$, air bubbles are artifacts); (d) dark, water soaked staining in freshly exposed sapwood in the root collar of a sugar maple tree positive for $C$. virescens. (Photos by Tara Bal). 


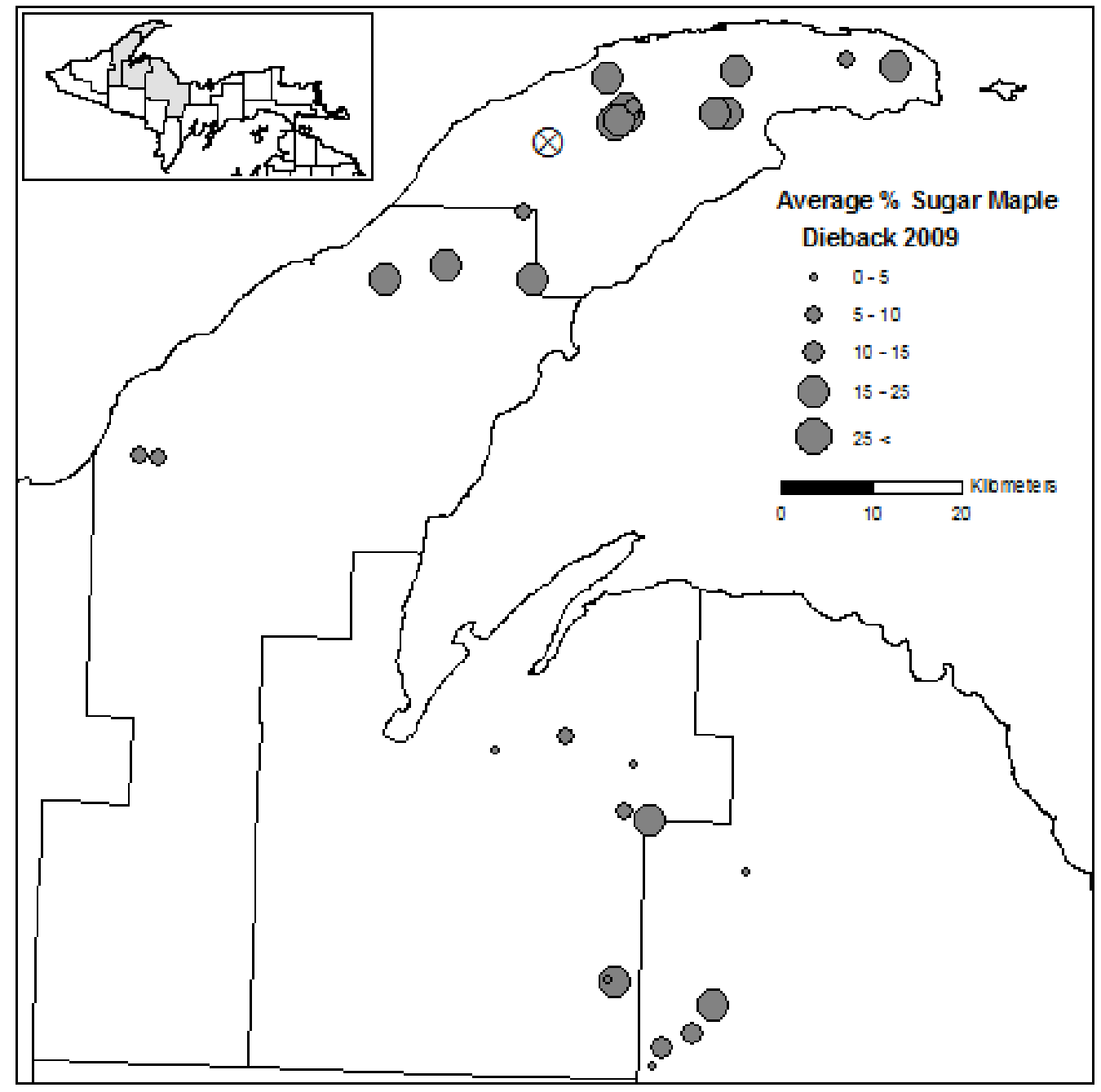

Figure 5.2. Locations of sugar maple dieback evaluation stands in Keweenaw, Houghton, Baraga, and Marquette Counties, MI. The mean percent of sugar maple dieback in each stand is shown: $\mathrm{X}$ indicates the location of the intensively sampled, recently harvested stand. 


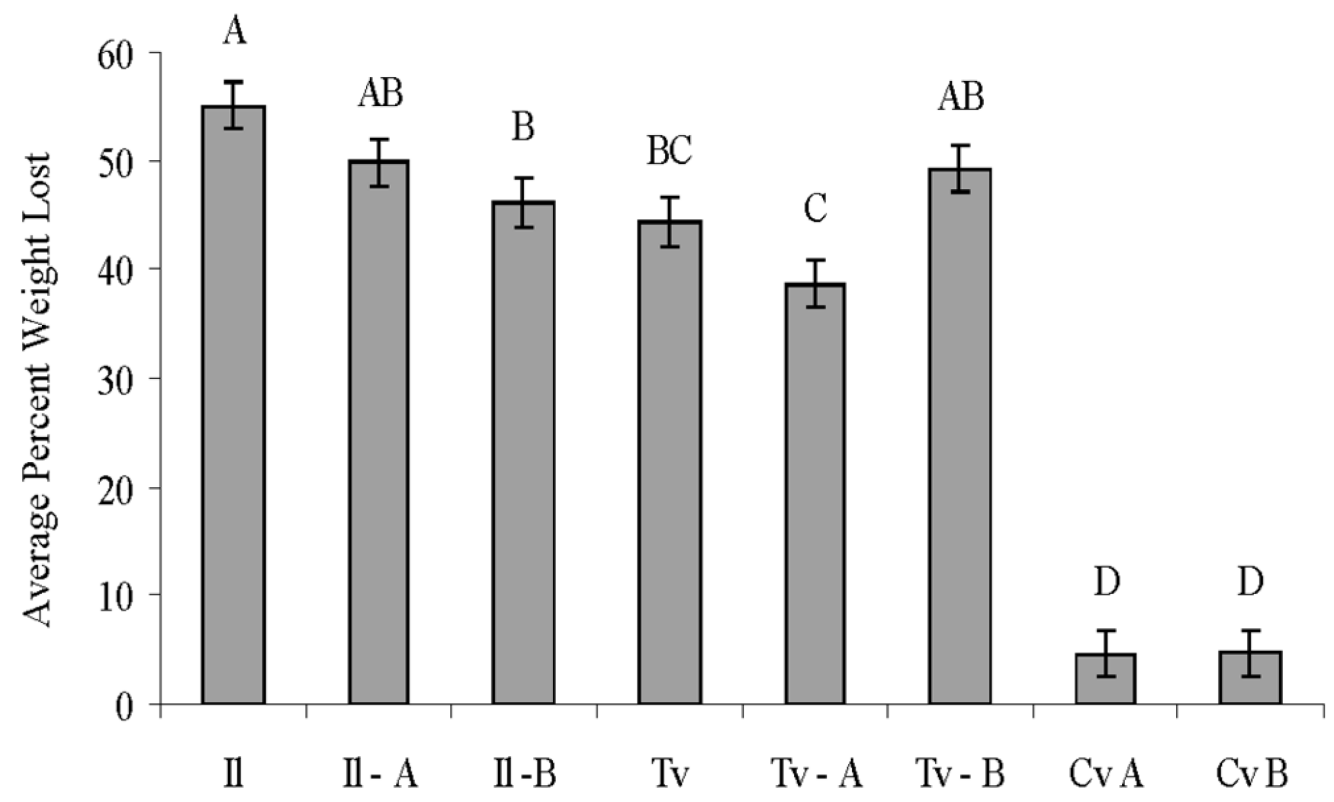

Figure 5.3. Mean percent weight loss of wood blocks by T. versicolor (Tv), I. lacteus (Il) and $C$. virescens $(\mathrm{Cv})$ after 8 weeks incubation (standard deviation included, $\mathrm{n}=10$ for each). The isolate used is labeled for each treatment with the decay fungi that were precolonized before the soil block decay test and for the $C$. virescens treatments alone. Letters on top of the bars indicate significant differences $(\mathrm{p} \leq 0.05)$ between treatments. 


\section{Chapter 6 Preface}

The material in the following chapter is formatted for and has been submitted for review to The American Biology Teacher, June 2013 under the same title, with Tara Bal as a single author. Appendix B contains a copy of an emailed permission letter from the managing editor of The American Biology Teacher for use in this dissertation. 


\title{
Chapter 6
}

\section{Forest Health Detectives ${ }^{5}$}

\begin{abstract}
Tara L. Bal
Ecosystem Science Center, School of Forest Resources and Environmental Sources, Michigan Technological University, Houghton, MI, USA
\end{abstract}

\begin{abstract}
'Forest Health' is an important concept often not covered in tree, forest, insect, or fungal ecology and biology. With minimal, inexpensive equipment, students can investigate and conduct their own forest health survey to assess the percentage of trees with natural or artificial wounds or stress. Insects and diseases in the forest are the focus, though student guides could be modified for many terrestrial or aquatic systems, depending on location. The lesson is geared to older students with suggestions for adaptation in younger grades as well.
\end{abstract}

The health of our forest ecosystems is vitally important not only for the plants and animals that live in them, but also for our own ecologic, economic, and aesthetic values. Forests produce oxygen, clean water, hold soil in place, and recycle nutrients. Tourism, recreation, timber, fiber, and hunting are just some of the multi-billion dollar industries dependent on forests each year. Forestry is an important aspect of biology that many students are exposed to, but few come away from the classroom with an understanding that forests and trees have diseases and stresses just as we do. Yet, lessons that do include forest health aspects such as insect attacks or destructive logging do not impart

5

The material in this chapter has been submitted and accepted for review in The American Biology Teacher. 
that damage and decay in some aspects are essential components of a healthy, recycling forest.

This forest health lesson can be correlated in many ways with other forestry and biology curriculum. Previous articles in The American Biology Teacher have integrated relevant forestry and ecology principles into biology lessons (Varbelow, 1963; McNew, 1966; Rhoades, 1974; Zipko, 1983; Glenn, 1995; Well Robinson, 2012). Project Learning Tree (http://www.plt.org), Project Wild (http://www.projectwild.org), and many agencies have dendrology (Glenn and Dickman, 2009), entomology, or mycology focused lessons available, but what most do not incorporate so well is the impact these disciplines have on overall forest health.

Recent trends and publications note the importance of hand-on nature learning and student engagement in learning in K-12 and above (Lightbody, 2008; Louv 2008; Ruiz-Primo et al. 2011). Insects and fungi are easy to find, collect, and investigate in a hands-on manner that is much harder for larger organisms or more abstract topics. Many of the National Standards for Science, Mathematics, Language Arts, and Social Studies can be addressed using forestry and natural resources based lesson plans and units. Forest health topics are a great way to cover content standards, use hands-on teaching techniques, and educate students about insect and disease ecology in their own backyards. The objective of this field investigation is for students to become familiar with forest health concepts. It is targeted for middle or high school students though younger students could do a shorter version and older students may delve further. This lesson plan has been implemented with a variety of K-12 students in Upper Michigan and was developed with feedback from teachers and students.

\section{Background}

The definition of a healthy forest depends on your perspective (Kolb et al., 1994). Timber managers may want to grow expensive trees and limit mortality. Wildlife sanctuaries may want to have as diverse a forest as possible for different animal species. 
Urban park managers may place priority on aesthetics and remove trees with decay or dead branches in the crown. Generally, the definition of forest health from an ecosystem perspective would be that a healthy forest would be one free from distress symptoms (Haskell et al. 1992). Forest distress symptoms include widespread, damaging insects, diseases, or other organisms that reduce productivity or biodiversity, disturb nutrient cycling, or reverse natural succession (Haskell et al. 1992).

Exotic or non-native insects and pathogens are usually a problem in any forest. Exotic organisms invade native ecosystems and can permanently alter them or outcompete and eliminate native species. For example, American chestnuts once covered almost 50\% of eastern North American Forests (Worrall, 2012). In the early 1900's, a fungal disease was accidentally introduced from Asia and by the 1940's, American chestnuts were tragically decimated, removing over 3.5 billion trees from our forests. More modern day examples could include the emerald ash borer, Asian longhorned beetle, hemlock wooly adelgid, Dutch elm disease, or beech bark disease. Exotic plants and earthworms also top the list as "ecosystem engineers" that dramatically affect the forest health and biological processes.

Abiotic stress must be considered when investigating forest health. Air pollution, climate change, forest fragmentation by roads and urban development, and insufficient fire cycles can all stress trees and forests. Human actions, either directly or indirectly, are linked to unhealthy forests. Increasing awareness of our influence on these problems can help us garner the knowledge to change behavior and help solve issues. By continually gaining the interest and educating students, forest managers, extension officials, policy makers, the general public, and others will we be able to keep our forests healthy.

Forest researchers, foresters, entomologists, and pathologists, and other professionals' complete tree or forest surveys to identify symptoms of healthy and unhealthy forests. Visual symptoms can include insect herbivory, wounds, scars or galleries on trees, leaf deformities or galls, mushrooms or fungal hyphae (decay), and dead or dying foliage or branches (Figure 6.1). The following procedure is for students to compare and contrast the health condition of two separate forest or woods areas. 
Students can use the provided symptom guides (Figure 6.2,6.3, 6.4) or make their own. With limited or no equipment, students can perform their forest survey at a school forest, a local park, or on street trees (see "Extensions" at the end of article).

\section{Data Collection}

\section{Materials and Equipment}

- Compass

- Measuring tape, preferably at least $10 \mathrm{~m}$

- Flexible measuring tape, (1 to $2 \mathrm{~m}$ long), or a "dbh" (diameter at breast height) tape that reads diameter, rather than circumference, to measure around trees. Premeasured pieces of string would also work.

- Visual symptom guides or worksheets

- Clipboards

\section{Procedure}

This lesson will have the most impact if students are able to compare the health of two areas. A good example would be a school forest and a park or recreational area. Street trees could be used as well. Contact local extension agencies, parks, or foresters for help in identifying local areas. Students should do all measurements and visual surveys.

1. Depending on the size of the group, break them up into pairs or groups and hand out equipment. Briefly review how to use the compass.

2. Assign students a plot center. Starting at $0^{\circ}$ North, students will count and examine each tree within a certain radius of a center person holding the tape (Figure 6.5). A typical radial plot size for surveys in hardwoods is $11.3 \mathrm{~m}(37.2$ feet radius, 0.04 ha, or $1 / 10^{\text {th }}$ of an acre). Reduce the radius size for younger students or to take up less time in a more dense forest. 
3. Each tree will be measured to compare health of larger and smaller or older and younger trees. If you are measuring circumference, divide the answer by $\pi$ (3.14159) to obtain the correct value. Approximately $1.37 \mathrm{~m}(4.5 \mathrm{ft})$ above the ground, wrap the measuring tape around the tree trunk perpendicular to the tree. Have students discuss if this works for every tree or not and if they should include dead trees.

4. Keep a worksheet of each tree number, size, and visual symptoms identified of tree health. Depending on location and species, some symptoms will be more common than others students could focus on those issues. Many trees will have more than one symptom which can all be recorded or have students choose the factor they think is most stressful to the tree. The Tree-Detectives Guide, Gallery Guide, and Gall Guide can be used as visual aids to identify symptoms. Have students sketch any unknown symptoms for later identification.

\section{Time Requirements}

Surveying trees in one, 11 meter plot takes between 30 and 90 minutes, depending on the number of trees and symptoms students' record. Summarization calculations and data analysis takes 20-30 minutes. It is suggested that teachers scout out the areas ahead of time to be familiar with the location and symptoms students will encounter.

\section{Suggested Class Schedule}

As this is primarily a lesson built on student experience outside, scheduling depends on availability. Two separate parks or forest areas could be visited in two, 50 minute sessions, with a $3^{\text {rd }}$ day for analysis and discussion. Alternatively, one afternoon of field trips would allow for all surveys and analysis to be completed.

\section{Data Analysis}


Have students calculate the percentage of healthy trees and those with symptoms determined by their survey and determine if larger or smaller trees are damaged or vigorous. A report summarizing the symptoms found, hypothesizing causes, and suggestions for forest health improvement could be turned in to the forest or park manager, or school principal. Data can be entered into spreadsheet software to analyze graphs (Figure 6.6) and use statistics where appropriate. Suggested analyses include:

- Number of trees with and without symptoms in the two areas visited (Figure 6.6A). Is one "healthier" than the other? Scale up the size of your plots to represent the number of trees per area (i.e. number of trees in 0.04 ha plot $\mathrm{x} 25=$ number of trees per hectare). Use mapping websites to determine how large your forest is. How many trees in the forest have symptoms?

- Number of trees greater than and number less than $10 \mathrm{~cm}$ dbh with and without symptoms. This represents current dominant trees $(>10 \mathrm{~cm})$ and the health of the future potential trees $(<10 \mathrm{~cm})$.

- Plot the size of trees per number of cankers, rotten spots, or insect galleries (whichever symptom you see most often) (Figure 6.6B). Some insects or pathogens only attack certain size trees or branches. For example, a forester can target large trees with many cankers in the next harvest to reduce the risk of smaller trees becoming infected as they grow.

- Percentage of trees with unhealthy symptoms that appear to be natural or caused by man(Figure 6.6C). Insect and disease damage is usually natural unless induced by anthropogenic causes. Residual logging damage, trees too close to roads, or vandalized trees are examples of human causes.

- Percentage of each visual damage symptom identified overall or by each forested area visited (Figure 6.6D). Are insect galleries more common or decay fungi? Are there a lot of trees with dead and dying branches? Is vandalism a problem in urban areas? 
Having students compile the data into a class report and see that it goes to someone capable of making decisions about tree health and management supports the message that trees and forests can be taken care of, similar to us when we are unhealthy.

\section{Extensions}

Forest health is an important topic that can be linked to biology, environmental science, entomology, botany, or agriculture concepts as well as social studies or current issue classes. They basic concepts and unanswered questions open the way for discussions and group or individual research. Rural or urban, private or public, naturally occurring or brought on by people, tree health is important to us all.

The Forest Health Detective lesson can be easily adapted for elementary grades. Provide magnifying glasses for students to examine evidence and symptoms as 'detectives.' Circular plots could be smaller or pre-measure a square plot and use flagging to mark the outside edges. Younger children may have an easier time focusing on one symptom or organism to investigate. For example, look in an urban recreational area for vandalized trees or a forest with an emerald ash borer infestation to search for the indicative galleries, exit holes, and sprouts at the base of trees. A survey could also be done along transect lines where a tree is measured that is closest to a person walking a line and stopping every 10 feet walking up and down lines in a forest. To do an urban street tree survey, have students examine trees between the sidewalk and street for a set amount of blocks.

Older students can go into more detailed diagnoses, research causes, and propose management solutions. Most insect and disease problems have accessible information on the web. They can identify trees to species or families (i.e. maples, oaks, birch, pine). A professional, detailed forest health survey would also include herbaceous and exotic species present. There are excellent online sources for ID in general or for specific regions (i.e. www.foretryimages.org, www.uptreeid.com, www.texastreeid.tamu.edu). 
Have the class put on a presentation to the park manager, land owner, school principal, etc., to encourage management for forest health. Older students can take digital pictures or illustrate insects, symptoms, or fungi and put together a forest health guide or walking tour pamphlet of forest diversity. Make copies of their publication available for the park, school, or land owner to use as a brochure or poster display.

Insect galleries are great for studying insect life cycles as there can be characteristic egg niches, pupal chambers, mating chambers, exit holes, and they increase in size as the larvae grows. Similarly, galls can be measured and linked to food webs, natural selection, and genotypic variation (CIBT, 2010).

The lesson and example symptom guides included here were developed for use in eastern forests though it could be easily adapted to any local terrestrial or aquatic ecosystem. For example, in prairie or savannah environments, do a survey for exotic grasses. Health indicator species of plants and macro-invertebrates are commonly sampled in streams and lakes (U.S. EPA, 2012). A survey for tree health can be done year round, even during winter just examining the tree trunk and branches.

\section{Glossary for Forest Health Detectives}

Canker: a disease of the bark layers that causes a well-defined sunken or swollen area Forest Health: the apparent condition of a forest, generally free from stress and able to perform biological and ecological processes

Hyphae: the branching, filamentous portion of a fungus usually seen as a white or dark matted patch under bark

Gallery: an insect hole, burrow, mine, or tunnel in wood or bark

Gall: abnormal growth or swelling by a plant in response to an insect or pathogen

Exotic Species: an organism introduced to another area outside of its native region or country

Leaf Miner: a type of insect that makes galleries in foliage, usually larvae feeding Mushroom: the fruiting body of a fungus that we usually see 
Symptom: any observable change in host (tree) structure or character such as swelling, scars, galls, wilting, or yellowing leaves

Wound: any open or scarred over break in the bark of a tree, either induced by natural causes or inflicted through human vandalism or equipment scrapes such as logging or plowing

\section{References}

Cornell Institute for Biology Teachers (CIBT) (2010). Goldenrod gall size as a result of natural selection. http://cibt.bio.cornell.edu/labs_and_activities/images/GoldenrodGalls.pdf

Glenn, D. (1995). Student field studies in forestry: a suggested paradigm for ecosystem research. The American Biology Teacher 57, 240-242.

Glenn, D.D. \& Dickman, D.I., (2009). Forestry field studies: A manual for science teachers. NSTA Press, the National Science Teachers Association. 102p.

Haskell, B. D., Norton, B. G., \& Costanza, R. (1992). What is ecosystem health and why should we worry about it? Pages 3-20 In: Costanza, R.; Norton, B. G.; Haskell, B. D. eds. Ecosystem Health. Island Press, Washington, DC. 269p.

Kolb, T. E., Wagner, M. R., \& Covington, W. W. (1994). Concepts of forest health: Utilitarian and ecosystem perspectives. Journal of Forestry 92(7), 10-15.

Lightbody, M. (2008). Investigating invasives: students study invasive species and support their local environment. The Science Teacher 75(8), 56.

Louv, R. (2005). Last child in the woods: saving our children from nature-deficit disorder. Algonquin Books of Chapel Hill, North Carolina. 343p.

McNew, G.L. (1966). The place of plant pathology in a general biology curriculum. The American Biology Teacher 28(6), 439-444.

Rhodes, W.E. (1974). Solidago galls in outdoor biology. The American Biology Teacher $36,420-422$.

Ruiz-Primo, M.A, Briggs, D., Iverson, H., Talbot. R., \& Shepard. L.A. (2011). Impact of Undergraduate Science Course Innovations on Learning. Science 331, 1269-1270

University of Minnesota (2011). Great Lakes Worm Watch. Natural Resources Research Institute, University of Minnesota, Duluth. http://www.greatlakeswormwatch.org.html

United States Environmental Protection Agency (2012) Monitoring and assessment: Chapter 4 macroinvertebrates and habitat. http://water.epa.gov/type/rsl/monitoring/vms40.cfm

Varbalow, T.H. (1963). A comparison of two stands of wild black cherry. The American Biology Teacher 25, 272-278.

Well Robinson, S. (2012). The growth of a pine tree. The American Biology Teacher 74(9), 620-627. 
Worrall, J. (2012). "Chestnut blight” http://www.forestpathology.org.html

Zipko, S.J. (1983). An interdisciplinary approach to forestry education. The American Biology Teacher 45, 387-392. 


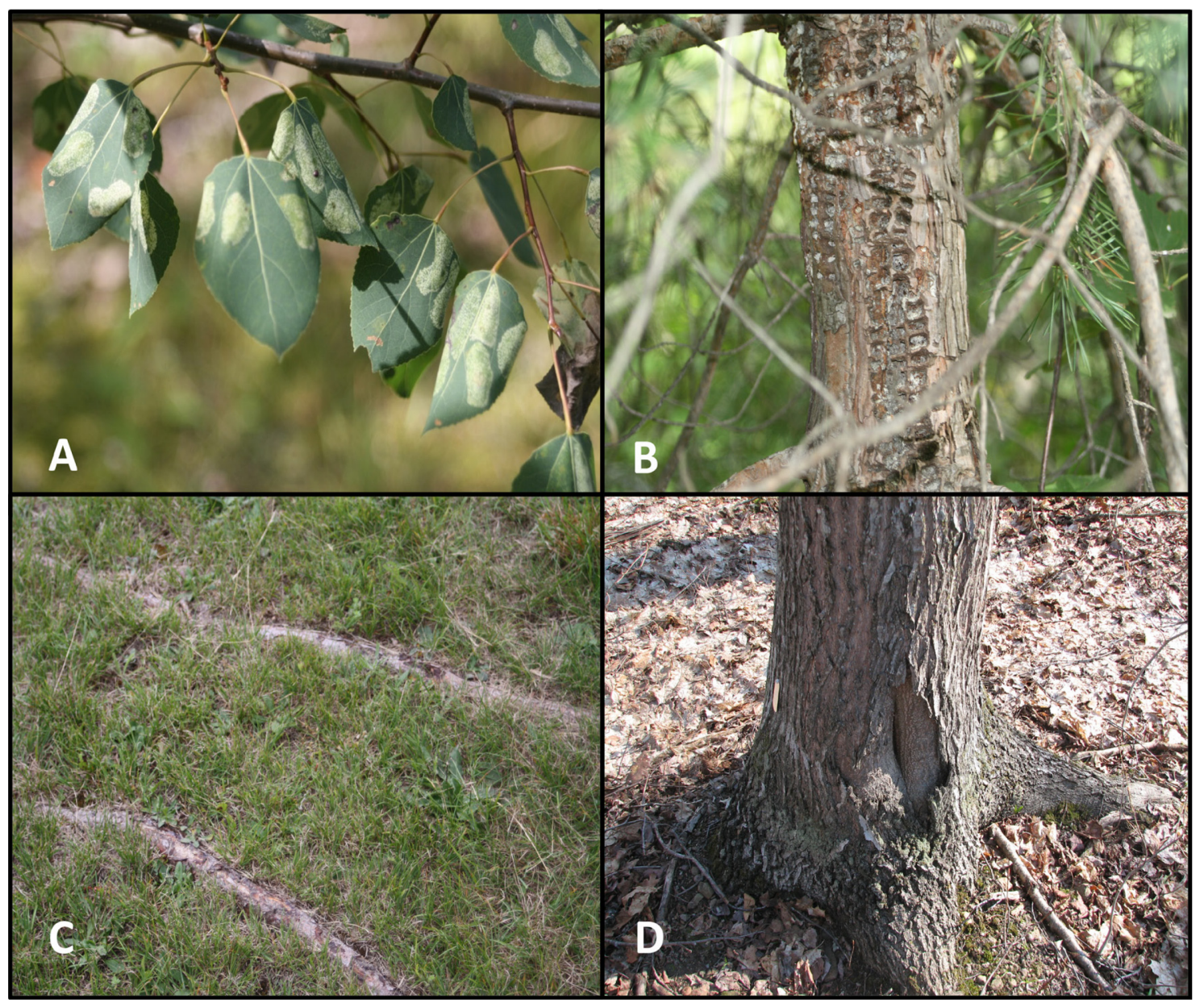

Figure 6.1. Examples natural and manmade tree health symptoms students may encounter: (A) leaf miner insects causing blotches in foliage, (B) sapsucker bird damage and scars in a tree trunk, (C) exposed tree roots damaged by a lawn mower (D) an old wound caused by logging equipment with decay inside. 


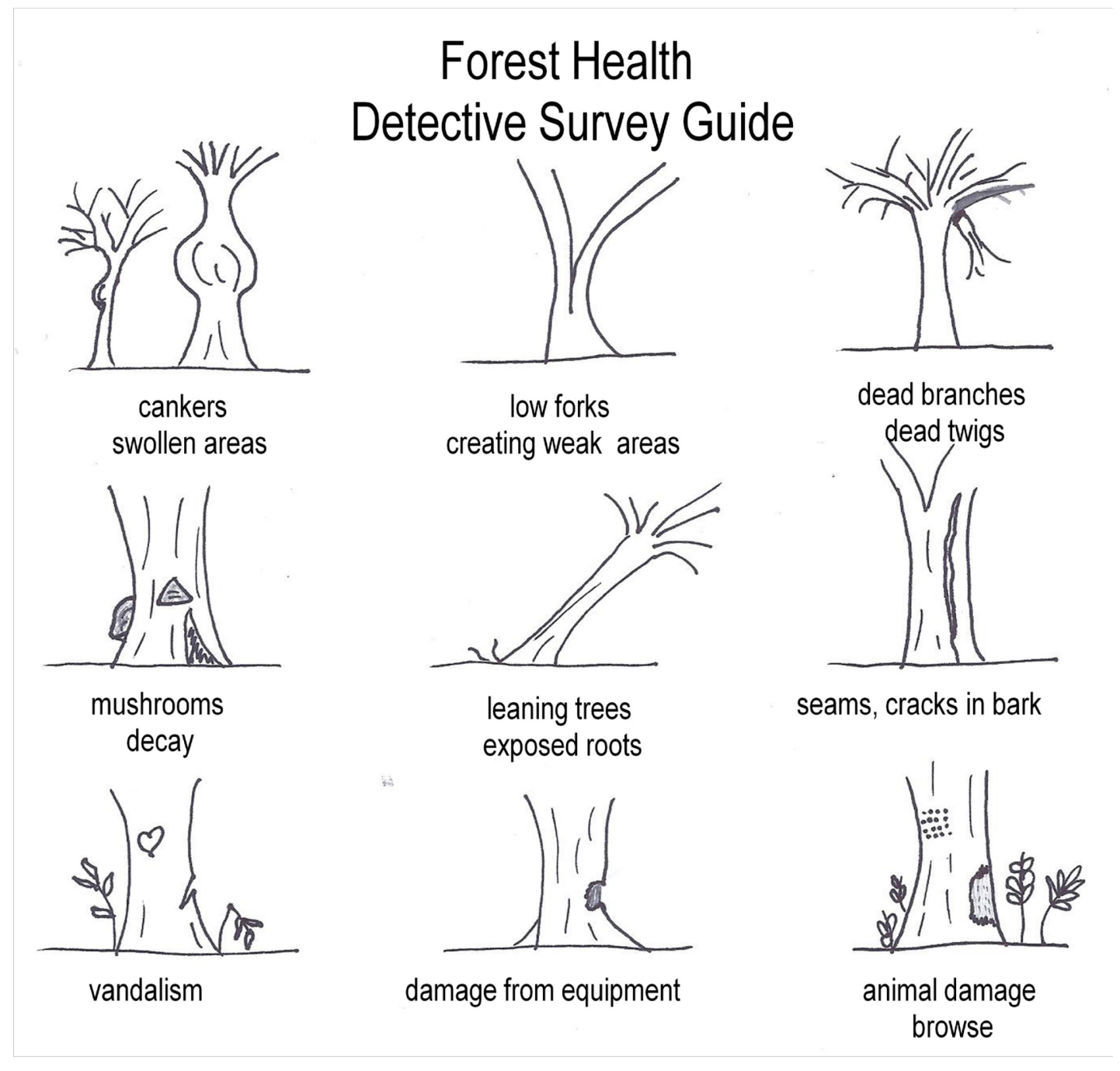

Figure 6.2. Forest Health Detective Survey Guide. A similar guide can be adopted for symptoms and conditions of trees and forests in your area. 


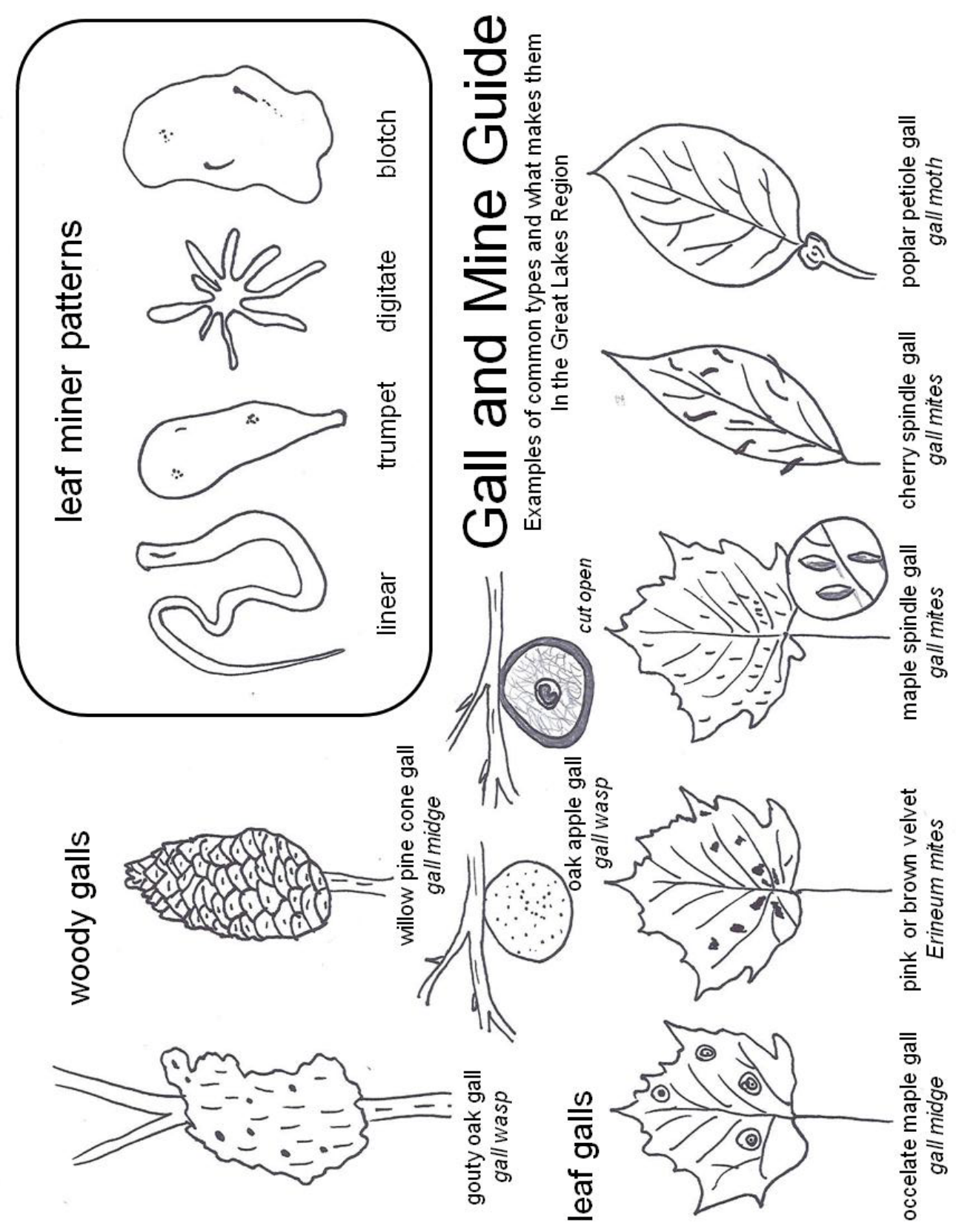

Figure 6.3. Gall and Mine guide for Forest Health Detectives for common types in the Great Lakes Region. If there are abundant galls or mines, even of native species, tree growth can be impaired. Similar illustrations can be made using field guides for other regions. 


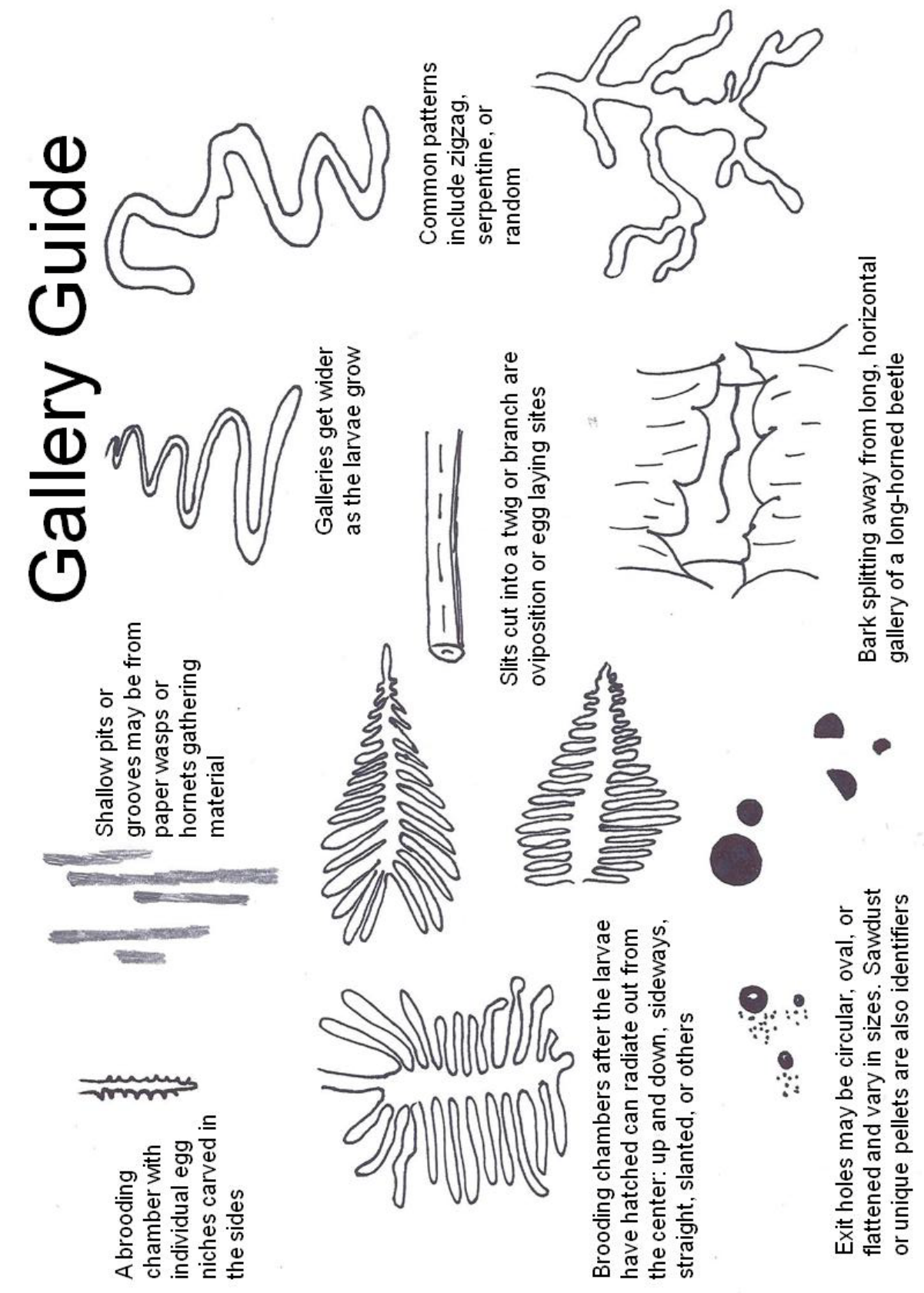

Figure 6.4. Gallery guide for Forest Health Detectives for common types found in the Great Lakes Region. Similar drawings can be made using observations or field guides for common galleries specific to a region or plant species. 


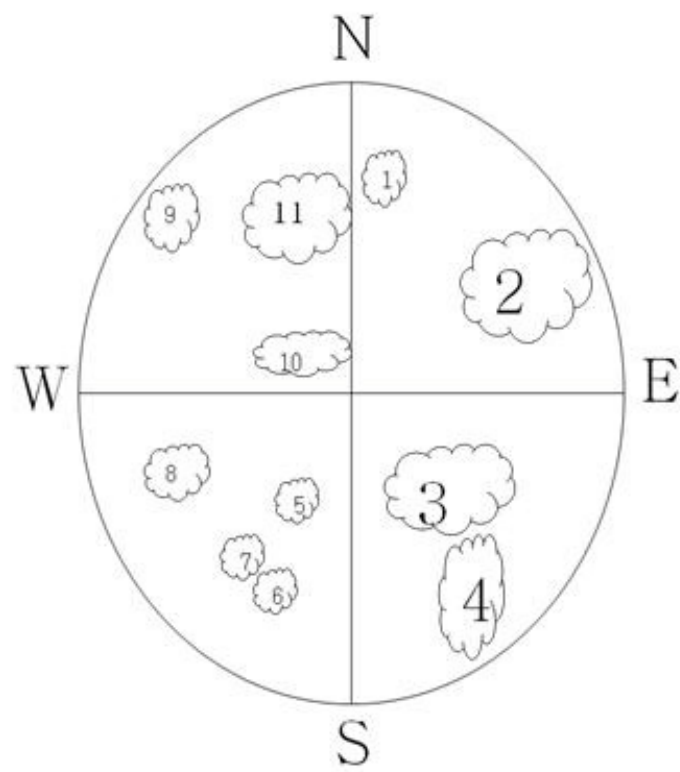

Figure 6.5. Illustration of numbering trees within a circular plot starting at $0^{\circ}$ north. 

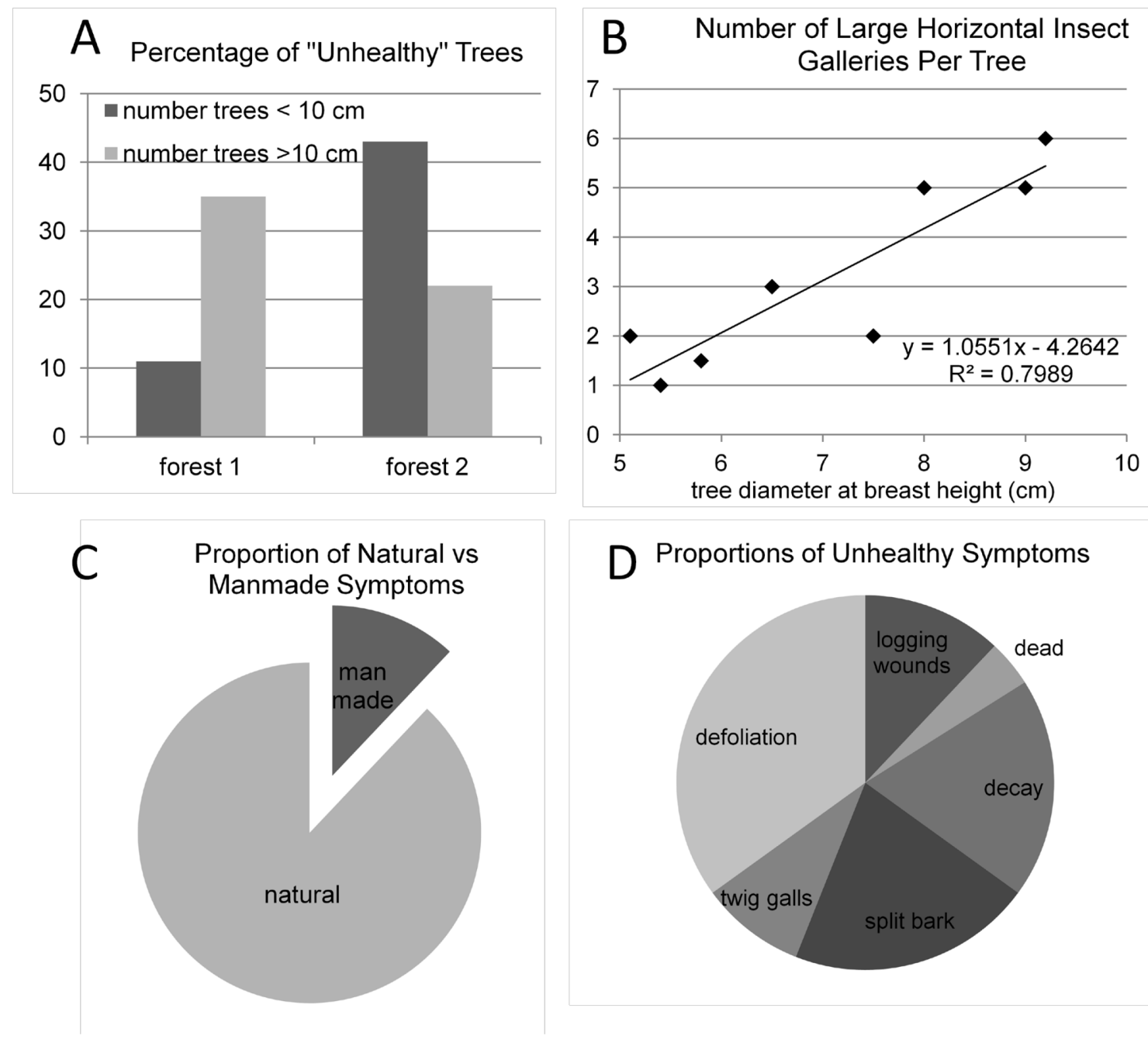

D Proportions of Unhealthy Symptoms

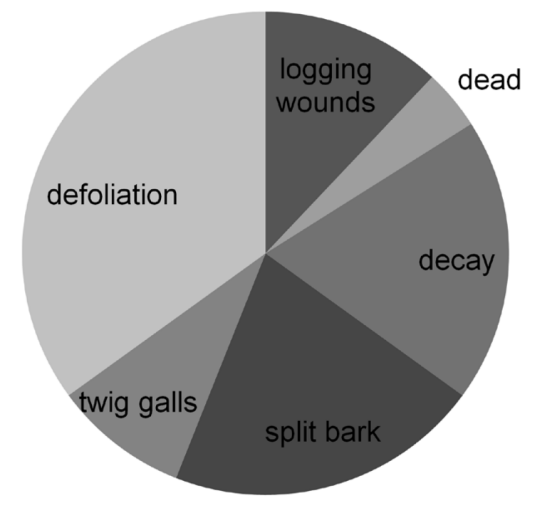

Figure 6.6. Example forest health survey analysis figures: (A) Bar chart of the proportion of trees with symptoms by diameter size, (B) Plot and trend line of number of symptoms by diameter, (C) Pie chart of natural and artificial symptoms, (D) Pie chart breakdown of the proportion of symptoms occurring on all trees. 


\section{Chapter 7}

\section{Conclusion}

A portion of the sugar maple stands investigated during this study appear to meet the criteria put forward by Manion (1991) for a true decline: a slowly progressive deterioration in health and vigor, primarily affecting mature cohorts of trees, decreased growth, increased dieback, and complex etiologies concerning biotic and abiotic factors. The research here highlights the need for comprehensiveness when evaluating sugar maple dieback etiologies. Current large scale databases such as atmospheric deposition,

soil survey information, climate variables, or defoliator outbreaks tend to miss localized, stand level factors that are contributing to forest health such as earthworm impacts, management history, or sapstreak.

Forest managers need to adopt practices that alleviate additional stresses in northern hardwood systems in anticipation of sugar maple dieback or reduced growth that may be already occurring. Harvesting impacts should be minimal or may need to be focused on even age management during drought or defoliation outbreaks to reduce residual loss. Rotation lengths, biomass removal, and harvesting intensity need to be evaluated in the context of residual sugar maple health. Harvesting exclusively in winter or using tracked equipment instead of tires can help protect soil conditions. Promoting other species rather than a virtual sugar maple monoculture, may significantly alter base cation concentrations in soils (Fujinuma et al., 2005), possibly alleviating nutrient competition stress on surrounding maple. Vegetation indicators and soil nutrition may indicate another species would be better suited for a site (Horsley et al., 2008).

Sugar maple is predicted to shift habitat suitability due to climate change over the next century (Iverson et al., 2008). Models predict over $90 \%$ of sugar maple habitat will be invaded by earthworms within the next 100 years (Gundale et al., 2005). It is unclear 
how the acclimation of tree physiological processes to earthworms, recurrent drought, and reduced snow cover will occur. Optimal nutrition and growth requirements for other northern hardwood and coniferous species in the Great Lakes Region should be examined more extensively to match sites and species as sugar maple growth becomes more limited and dieback increasingly common in the presence of climate change and invasive species.

\section{References}

Gundale, M.J., Jolly, W.M., Deluca, T.H. 2005. Susceptibility of a northern hardwood forest to exotic earthworm invasion. Conserv. Biol. 19: 1075-1083.

Horsley, S.B., Bailey, S.W., Ristae, T.E., Long, R.P., Hallett, R.A. 2008. Linking environmental gradients, species composition, and vegetation indicators of sugar maple health in the northeastern United States. Can. J. For. Res. 38: 1761-1774.

Iverson, L.R., Prasad, A.M., Matthews, S.N., Peters, M. 2008. Estimating potential habitat for 134 eastern US tree species under six climate scenarios. For. Ecol. Manage. 254: 390-406.

Fujinuma, R., Bockheim, J., Balser, N. 2005. Base-cation cycling by individual tree species in old-growth forests of Upper Michigan, USA. Biogeochemistry 74: 357376.

Manion, P.D. 1991. Tree disease concepts. Prentice-Hall, Englewood Cliffs, NJ. 


\section{Appendix A.}

\section{Forest Detectives: Insects and Diseases in the Great Lakes Area}

Program for introducing students grades 6-11 to forest health issues in the Great Lakes Region

Designed for use during Michigan Technological University summer youth programs

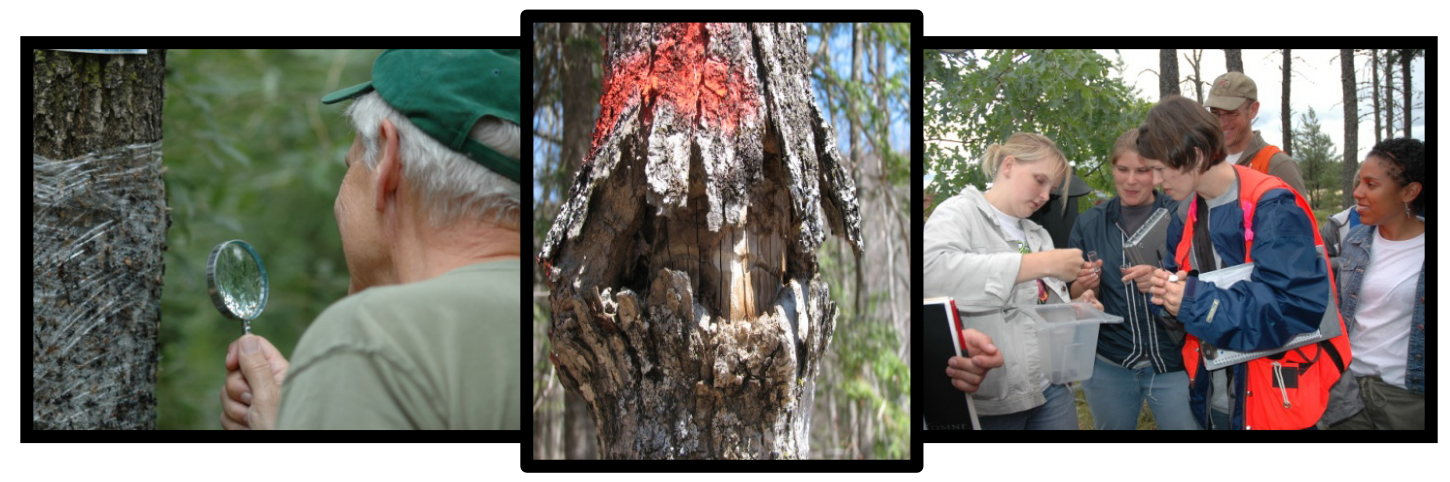

Figure A.1 Investigating insect and diseases in the Great Lakes Region. Photos by Andrew J. Storer, Tara L. Bal 


\section{Table of contents}

1. Introduction

a. Overview of lessons

b. General schedule for use in Michigan Tech Youth Program

-Suggested field sites

2. Detailed lesson plans for field investigations

Day 1 - Forest Health Introduction

- Overview of insects

- Pitfall traps

- Insect collection hike

- Grandiose galleries

Day 2 - Forest Forays

- Emerald ash borer surveyors

- Leaf litter life

- Tree and plant ID

- Moth walk and butterfly feeders

Day 3 - Underground and Around

- Rhizotron tour

- Earthworm assemblies

- Fungal forays

Day 4 - Insect-ti-gators

- Galling galls

- Tree detectives

- Caterpillar capers

- Miniscule miners

Day 5 - Collection day

- Trap collection

- Working terrariums

- Insect and fungi collections

3. Supplemental Materials/Resources

a. More ideas to integrate into Forest Health lessons

b. Print Resources

c. Online Resources 


\section{Introduction}

\section{Overview}

This unit of activities and investigations of forest health issues was developed for use as a weeklong program introducing students to forest insect and disease ecology in the Great Lakes Region. Forest insects and diseases are negatively impacting many ecosystems worldwide and are easy topics to discuss, identify, and investigate in a natural field setting. Michigan Technological University's summer youth program is an ideal application to introduce many students to these lessons either as part of another ecology based unit or this entire unit. The youth programs at MTU are for grades 6-11; however any of the lessons included here could be adapted for other grades or used to supplement classroom lessons. The topics and activities in this unit are intended to introduce students to the idea of the study of forest insects and diseases and encourage creativity and critical thinking. Also included is a list of supplemental ideas, resources, and materials for bringing forest health related issues into the K-12 classroom or for other ecology based units.

\section{Forest Insects and Fungi}

The lessons here focus heavily on forest insects and diseases in the Great Lakes region and are intended as an introduction to the broader topic of forest health. Online supplemental materials for forest insects, diseases, or forest health are in limited supply, especially for Midwest or Great Lakes region. There are many ecology and biology focused lessons available, especially for elementary and middle school, but what most of these lessons seem to lack is the tying together of different forest insects and diseases and the impact that they can have on an ecosystem. Insects and fungi are also easy to find, collect, and investigate in a hands-on manner that is much harder for larger organisms or more abstract topics.

When the emerald ash borer (Agrilus planipennis) was first identified in Michigan, it was further determined that it had been present in the Detroit area for possibly 10 years or more before discovery. A small green beetle may pass unnoticed but the amount of trees that were infested, weakening, and dying should have been a wakeup call to citizens and professionals long before it actually was. Public awareness and education in forest health topics can only benefit us if started in grade school.

\section{Activities}

The entire unit presented here is intended to be used in a fun, exciting, summer camp style program to increase student interest in a topic. Therefore, some topics are presented as lessons with data sheet and discussion topics, but most should be presented to students in an engaging manner with a lot of free exploration time built in. Also included are suggested areas for going into the field if this unit was based in Houghton, MI (MTU) but similar hardwood forests, conifer forests, open fields, and other natural areas could easily be substituted. There are projects for students to take back home with 
them and feel like they contributed to active research as scientists, all while enjoying natural settings that they may not be familiar with.

\section{Contact Information}

If you have any questions or comments about the unit or lessons included here, please feel free to contact me.

Tara L. Bal

$\mathrm{PhD}$ Candidate

School of Forest Resources and Environmental Science

Michigan Technological University

tlbal@mtu.edu

906-281-6241

\section{General schedule for 5 day program}

Suggested locations included are areas within easy driving distance of MTU,

Houghton, MI but other regional areas or similar areas could be substituted.

\section{Day 1: Ford Forestry Center, Alberta MI}

Introduction and Icebreaker (Forest Health Scavenger Survey)

Pit fall traps in grassy or burned area

Insect Collection Hike \& Grandiose Galleries

Day 2: Calumet, MI: Swedetown Trails: Tech Trails at dusk

Emerald Ash Borer Surveyors

Leaf Litter Life

Tree ID and Plant Hike

Moth Walk at dusk and Butterfly Feeders

\section{Day3: Tech Trails, Houghton, MI}

Rhizotron tour \& Earthworm sampling

Fungi Count and Collection

Fungi of Tech Trails Pamphlet

Future Fungal Fun (Spores)

Day 4: McClain State Park or Fort Wilkins: Estivant Pines: Lake Manganese:

Brockway

Galling Galls

Tree Health Detectives

Caterpillar Capers

Miniscule Miners

Day 5: Ford Forestry Center, Alberta MI: Sturgeon Falls: Tech Trails 
Pitfall Trap Collection and Sorting - Alberta

Working Terrarium Jars - MTU

Put Together Insect and Fungi Collections - MTU 


\section{Day 1: Insect Intro \& Forest Health}

\section{Overview}

Students will use an icebreaker to think about what does the term "forest health" means and the importance of insects and fungi. Students will have the chance to collect and make their own insect and/or fungi collections during the week for themselves or to donate to local elementary schools. Students will construct their own underground pitfall traps that will be collected at the end of the week and have the option of trap location to see who can trap the most diverse insects. Hiking through different conifer and hardwood forests will give students an opportunity for insect gathering and gallery collection for a creative art project

\section{General Activity Schedule}

1. Introduction and Icebreaker

2. Pit fall traps in grassy or burned area and forest area

3. Insect Collection Hike

4. Grandiose Galleries

\section{Activity \#1 - Introduction and Icebreaker}

What is Forest Health and why are Forest Detectives Important? What do you think of when you hear forestry? Can our forests be 'healthy' or the opposite, 'ailing' or 'sick'? Students who graduate can become forest managers, logging, wildlife managers, wolf specialists, wood product specialists, map makers, conservationists, bird rehabilitators, ect... ( list forestry and environmental careers).

"I'm a special kind of forester, a forest health expert. Has anybody ever heard of a healthy forest? or the words 'forest health'? We're going to do a quick scavenger hunt and see if you can tell me what you think forest health relates to afterwards? Your job is to go around and have the people here sign their name if they have done or can do these things.

Did you get them all filled out? What do you think forest health means?" 


\section{Forest Health Scavenger Survey!}

Your goal is to fill in as many categories below as possible by having people around you fill in their initials next to the appropriate line and answering the questions. No signing more than three times for any person... that includes you!!

1) ...has heard of emerald ash borer

2) ...has ever planted a tree

3) ...can name 5 different kinds of insects (list them!)

4) ...has ever gone camping at a campground

5) ...has ever caught a ladybug

6) ...knows the difference between oak and maple leaves

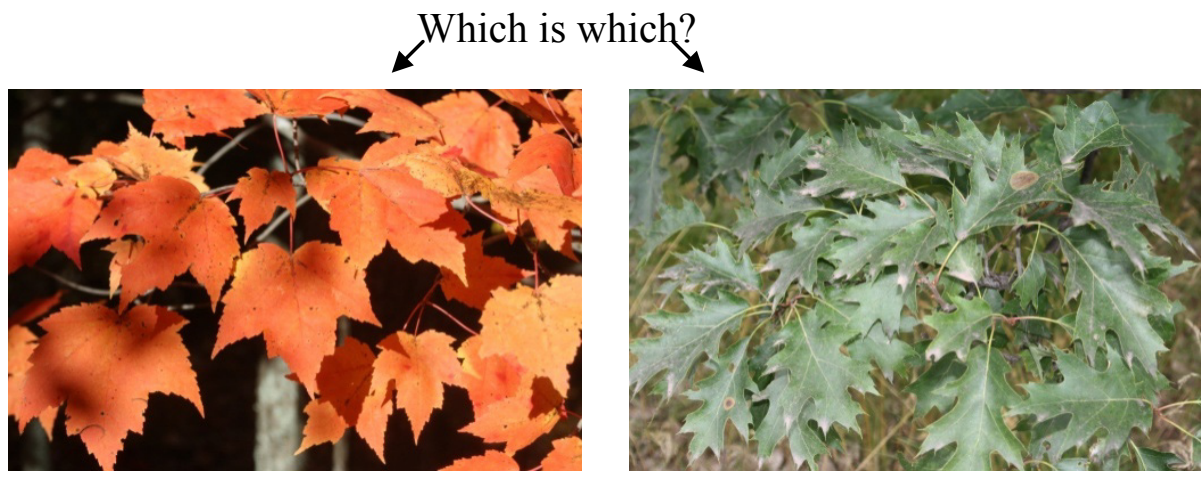

Figure A.2. Different shaped oak and maple leaves.

7) ...has been stung by a bee!

8) ...can tell you what caterpillars turn into...?

9) ...likes eating mushrooms on their pizza

10) ...has ever pulled a weed out of a garden

11) ...is scared of spiders

12) ...knows the name for seeds from an oak tree?

13) ...can draw an ant, (draw here)

14) ...has seen an animal eating a plant outside

15) ...has picked a dandelion 


\section{Activity \#2 - Pitfall Traps}

Arthropods are excellent indicators of biodiversity. In this activity, the abundance and species richness of ground-dwelling arthropods is measured by placing pit-fall traps across a range of forest types or treatments either hardwood forests, or open adjacent areas (if done at Alberta, MI, a jack pine regeneration study area (Sec 14 T49N R34W) is an ideal place for multiple treatments and to discuss the impact of fire on forest health).

The pitfall traps are made with a plastic cup or margarine container, placed in the ground so that the top of the cup was flush with the surface. An inch of 50\% propylene glycol (antifreeze) is put in the cup as an attractant and insecticide if collecting insects. Students can experiment with pieces of fruit, bread, or meat to see which baits work best. Styrofoam (for rain) or paper plates are held in place (by nails, sticks, or kitchen skewers) over the trap, drawing insects under it into the cup and to keep out any predators. For each area sampled, put in multiple pitfall traps, starting at a random location, five meters apart and heading in a randomly selected direction. Leave traps for as long as possible (no longer than 10 days) and collecting, sorting, and counting will be on the last day.

You can make this project more exciting by making it a competition with a secret prize available at the end (an insect poster, plastic bug figurines, insect decorated cupcakes, ect) for the group who has the greatest insect abundance, richness, or diversity on the last day. The total \# of individual insects is abundance. The total \# of insect species is richness. Species diversity can be calculated a number of ways, a common one being the ShannonDiversity Index:

$\mathrm{H}=\sum_{\mathrm{i}=1}^{\mathrm{s}}-\left(\mathrm{P}_{\mathrm{i}} * \ln \mathrm{P}_{\mathrm{i}}\right)$

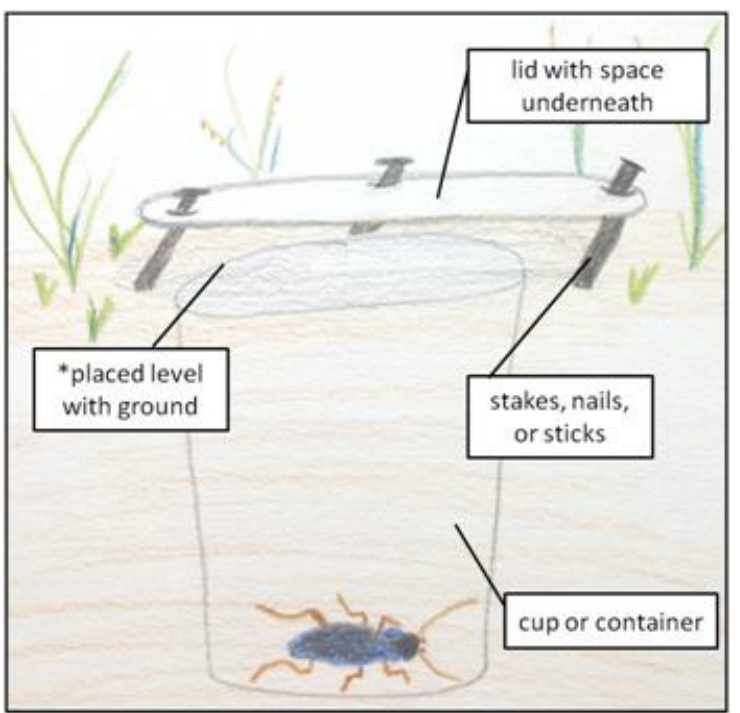

Figure A.3. Pitfall Trap Diagram

\section{Activity \#3 - Insect Collection Hike}

A weeklong project for the students to keep in mind starting as soon as possible is to have a professional style insect collection that will be put together the last day of the program for students to keep and use themselves, or to donate to local elementary schools that are in need of educational material. On any hike throughout the week, students will 
keep Ziploc baggies, tweezers, or vials on hand to collect any insects they find. Look under tree bark, shake bushes, use traps, use nets, or other methods to collect insects. Keep student names on collection bags and place in a freezer at the end of each day. By day 5, insects will be ready to pin and label in boxes. Entomological boxes can be used or each student can use a shoe box or other cardboard lid with a piece of $1 / 4$ " foam inserted in the bottom for pins to stand in. See Day 5 for pinning techniques.

\section{Activity \#4 - Grandiose Galleries!}

Groovy Science: Different insect species make different patterns of signs on and in wood. They may have a particular type of frass, use only a certain type of tree, use only a certain condition of wood, or have a tell-tale pattern. Several make shallow grooves or pits, large open seemingly random galleries, or patterned galleries. The most basic bark beetle galleries have a central mating chamber (a linear tunnel) with several evenly spaces egg niches carved into the sides. You can find galleries with just the small egg niches or a central straight line from the parent and lots of lines radiating out made by the larvae, looking almost like a giant centipede. Other beetle galleries may be zigzagged or serpentine in shape, starting out small and getting larger as the larvae grow. Long-horned beetles tend to make just a long straight line. Galleries are great conversation starters for insect life cycles and nutrition. Use the Gallery Guide to see how many different types of galleries you can find.

Art Ideas: On any hike, look for and collect twigs, branches, or chunks of wood with galleries in the wood under bark. Flatten a piece of polymer clay into a disk and press onto galleries or tunnels to make an imprint in the clay. A toothpick or straw will make a hole for a necklace and follow instructions on polymer clay for baking and hardening.

Make a bark rubbing by holding or taping a piece of paper over the gallery and lightly rubbing a crayon or chalk over the paper

Find a stick covered in galleries and paint it a solid bright color. Use a roller with black or a contrasting color to lightly go over the outside of the stick (so you don't fill in the galleries with the dark color. Or paint it the opposite way so the galleries are darker. The result is a neat decoration with the insect galleries highlighted.

Figure A.4. Insect gallery art.

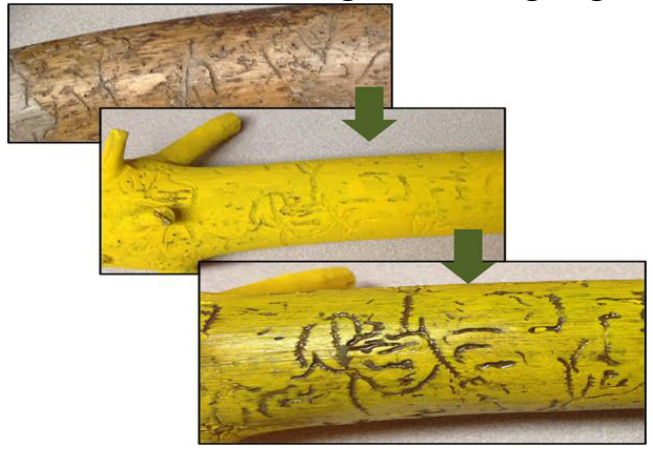




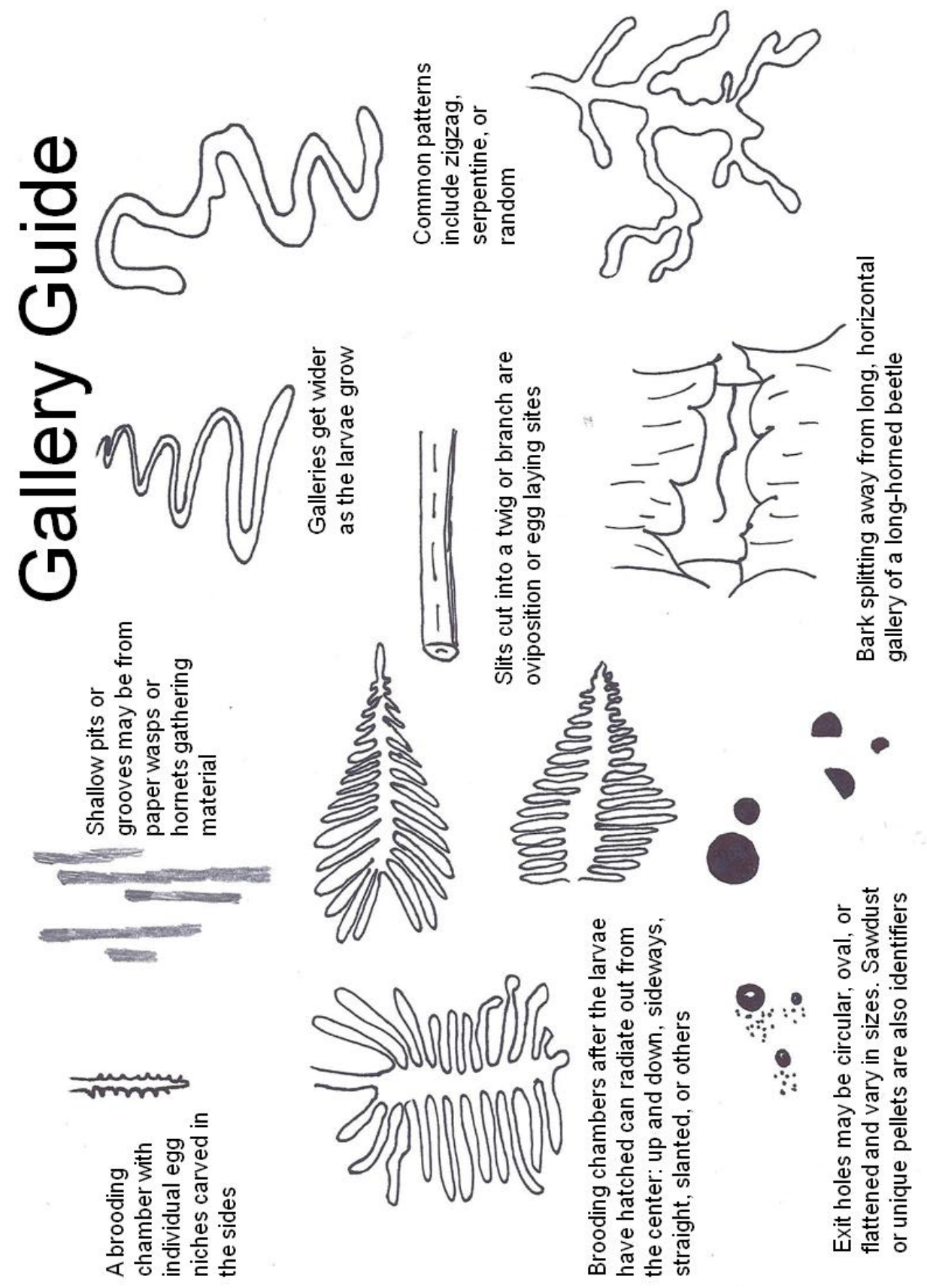

Figure A.5. Gallery Guide to insects found the Great Lakes Region. 


\section{Day 2: Forest Forays}

\section{Overview}

Students will conduct a survey in a local forest or woodlot for the presence of an exotic insect in Michigan and other damaging tree agents. Another afternoon hike will allow for more insect collecting and students to learn basic tree ID and some exotic, invasive weeds. After dinner, students will meet to prepare syrup and watch or trap moths near campus or another nearby forest location.

\section{General Activity Schedule}

1. Forest Survey for Emerald Ash Borer

2. Leaf Litter Life

3. Tree ID and Plant Hike

4. Butterfly Feeders and Moth Walk at dusk

\section{Activity \#1 - Forest Survey for Emerald Ash Borer}

Resource: Beachy, J.W., 2009 Dissertation. Lesson 3: Conduct a local survey for Emerald Ash Borer In The development and trapping, survey, and educational tools for the exotic invasive emerald ash borer (Agrilus planipennis Fairmaire) (Coleoptera: Buprestidae).

In advance of activity, locate a place in Calumet, school grounds, or nearby park with a stand of ash trees that has been infested with emerald ash borer or look for another insect species or damage, such as sugar maple borer or tree cankers. Contact local park managers or foresters for areas with emerald ash borers. This activity can be adapted for street trees as well. Create a data sheet for students to record their tree \#, size of tree, species, and symptoms detected.

Explain to students that today they will be acting forestry professionals conducting a survey for tree damage from an insect. They will be doing transects to help count and quantify signs of damage on trees just as a forest entomologist or forest health expert would do. They will be looking for ash trees, measuring them, and recording signs of health of the tree for research.
Materials:

For Forest Survey

- clipboards for data entry sheet

- pencils

- EAB ID cards if looking at ash trees

- flagging or tree crayons

- diameter tape

- 40’ measuring tape

For Leaf Litter Life

- stiff paper for a cone

- glass jar

- lamp or heat source

- trowel and baggie for sample collection

For Tree, Weed ID

- tree/ weed field guides

- tree bingo cards

For Moth Walk and Feeder

- overripe fruit, juice

- sugar, molasses, honey

- paintbrushes

- blender

- flashlights

- $\quad$ paper plate and string 
- $\quad$ Some of our trees are in trouble! Just like people and animals, trees can become weak, unhealthy, get injuries, and die.

- What are ways people and trees can get sick or unhealthy? (poor nutrition, polluted water, no food or water, poison, disease, physical injury).

- How are ways we combat these things? (proper diet, exercise, safe behavior, limit spread of disease, heal).

Depending on size of group, break them up into pairs or groups. Hand out clipboards, pencils, worksheets, EAB identification guides (optionally, build a similar guide for another common insect or problem, i.e. sugar maple borer, Nectria canker, beech bark disease, ect.), pencils, tree crayons or flagging, measuring tapes. Assign each group a different area, and tell them that they are going to count and examine each tree within a certain radius of a center person holding the tape ( 37 feet is $1 / 10^{\text {th }}$ of an acre). Reduce the radius size for younger kids or to take up less time in a more dense forest so they have less to measure. Use tree crayons or flagging to mark trees that you've measured in a circle (see diagram). A survey could also be done along transect lines where a tree is measured that is closest to a person walking a line and stopping every 10 feet walking up and down lines in a forest.

- $\quad$ To do a forest survey, we can't closely examine every tree in the forest! That would take forever.

- So, foresters and ecologists measure "plots" or a small subsection that represents the rest of the forest.

- We're going to closely examine each of the trees within our plot area and record in our notes using the Tree Trouble guide or data sheet whether the tree had any symptoms of being unhealthy.

After explaining the measurements, practicing on a few trees, and conducting the survey, summarize the data as a group. You can share your results with local forest managers or the local Slow Ash Mortality Manager if working in Calumet, MI.

- What health issues did they find? What types of trees were they on the most? Were there

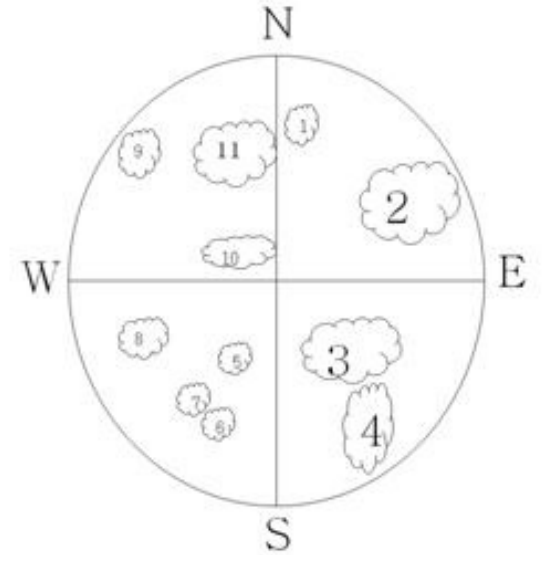

Figure A.6. Plot tree numbering diagram.

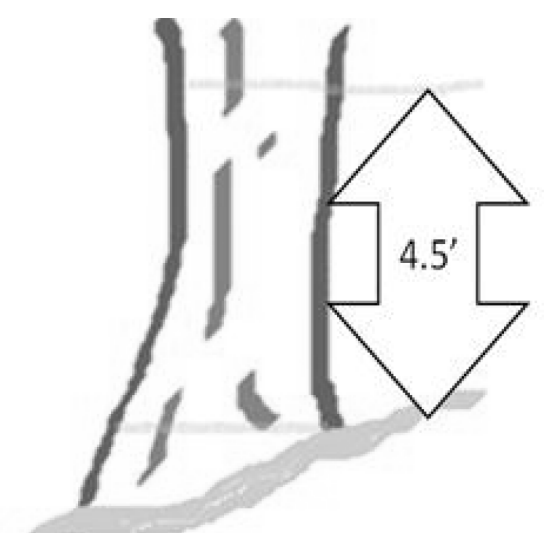

Figure A.7. How to measure tree diameter at breast height. 
areas with more issues (edges, recently logged areas, ect).

- What can we do to help make these trees or this forest more healthy?

- Remember that native insects and diseases play an important role! They are recyclers that help the nutrients from dead and dying trees return to the soil and make room in the forest for regenerating trees. So some insects and diseases are O.K. but when are they not O.K.?

Tree Measurements: To take diameter measurements, called d.b.h. by professionals, (diameter at breast height) use a diameter tape or D-tape. If you do not have access to this equipment, you can use a standard cloth measuring tape (or even pre-measure lengths of string) and divide your answer by $\pi(3.14159)$ to obtain the correct value. The d.b.h. is measured at $4.5 \mathrm{ft}$ above ground from the uphill side of the stem. Wrap the measuring tape around the tree perpendicular to the angle of the tree bole. Have students discuss if this works for every tree or not.

\section{Activity \#2- Leaf Litter Life}

You can use insects collected from this activity as part of your insect collections or release them the next day. You may want to set this up early in the morning or at the end of the day to check the following morning, depending on how fast the insects emerge. Antonio Berlese was an entomologist who specialized in mites and insects that live in the soil. Hundreds of tiny creature may be in one small of cup of soil, so he developed this method to get them out so he could study them! Gather a scoop of soil or leaf litter and support it in a paper cone, with a small hole at the bottom or a small screen inside, on the inside of a glass jar. Put the soil and jar about 12 inches under a lamp or hot light bulb. As the soil warms and dries out, the small creatures move further and further down until they fall out the bottom into the glass jar. Look for springtails, thrips, rove beetles, woodlice, millipedes, earwigs, centipedes, snails, grubs, worms, pseudoscorpions, and more. Compare different types of soil (sandy or loamy), with or without leaf litter, or different types of leaf litter.

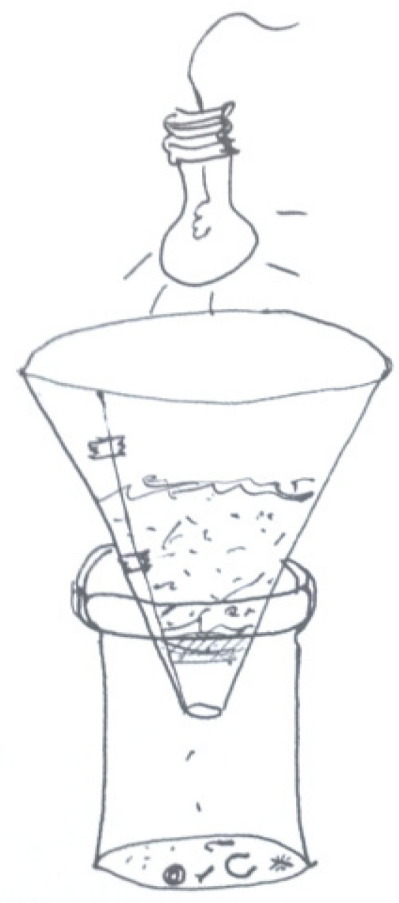

Figure A.8. A Berlese funnel. 


\section{Activity \#3 - Tree ID and Plant Hike}

Use multiple tree and plant field guides and hike with a knowledgeable guide around any trail system (i.e. Swedetown Trails if in Calumet, MI already for the day). Look for as many different types of trees as possible and identify invasive weeds. Invasive weeds at Swedetown Trails include spotted knapweed, glossy buckthorn, multiflora rose, and probably others. Also use this time for insect collections. Make it more exciting by creating bingo cards using locally available species and forest findings.

\begin{tabular}{|c|c|c|c|c|}
\hline B & I & N & G & O \\
\hline aspen & yellow birch & balsam fir & $\begin{array}{c}\text { sugar } \\
\text { maple }\end{array}$ & 3 acorns \\
\hline $\begin{array}{c}\text { woodpecker } \\
\text { holes }\end{array}$ & thimbleberry & $\begin{array}{c}\text { spotted } \\
\text { knapweed }\end{array}$ & red pine & $\begin{array}{c}\text { paper } \\
\text { birch }\end{array}$ \\
\hline ash & red oak & FREE & $\begin{array}{c}\text { conk } \\
\text { mushroom }\end{array}$ & tag alder \\
\hline $\begin{array}{c}\text { goldenrod } \\
\text { gall }\end{array}$ & honeysuckle & $\begin{array}{c}\text { earthworm } \\
\text { castings }\end{array}$ & $\begin{array}{c}\text { white } \\
\text { flowers }\end{array}$ & $\begin{array}{c}\text { deer } \\
\text { browse }\end{array}$ \\
\hline $\begin{array}{c}\text { paper birch } \\
\text { bark }\end{array}$ & $\begin{array}{c}\text { insect } \\
\text { galleries }\end{array}$ & red maple & litter & $\begin{array}{c}\text { jelly } \\
\text { fungus }\end{array}$ \\
\hline
\end{tabular}

Table A.1. An example Plant ID bingo card. 


\section{Activity \#4 - Moth Walk and Butterfly Feeders}

Mix overripe fruit, stale beer, or wine, juice, and a sweetener (honey, molasses, sugar, pancake syrup) in a blender till you have a sticky, syrupy consistency. Some entomologists swear by brown sugar and rotten watermelon! At sunset, use paintbrushes to paint concoction on different trees in woods or on edges or unpainted wood surfaces. If you want to take pictures of moths, make the concoction thick and not runny so ants take longer to find it. Ants may disturb feeding moths away from your bait. Use a flashlight when full dark to see moths, ants, earwigs, and other creatures attracted to the brew. Enjoy some s'mores or other snack while waiting for the show to start!

Leftovers the next day will attract butterflies. Paint a small amount on a paper plate and hang it from a branch to make small butterflies easier to see. It should be slightly runny and thin so the butterflies can suck it up.

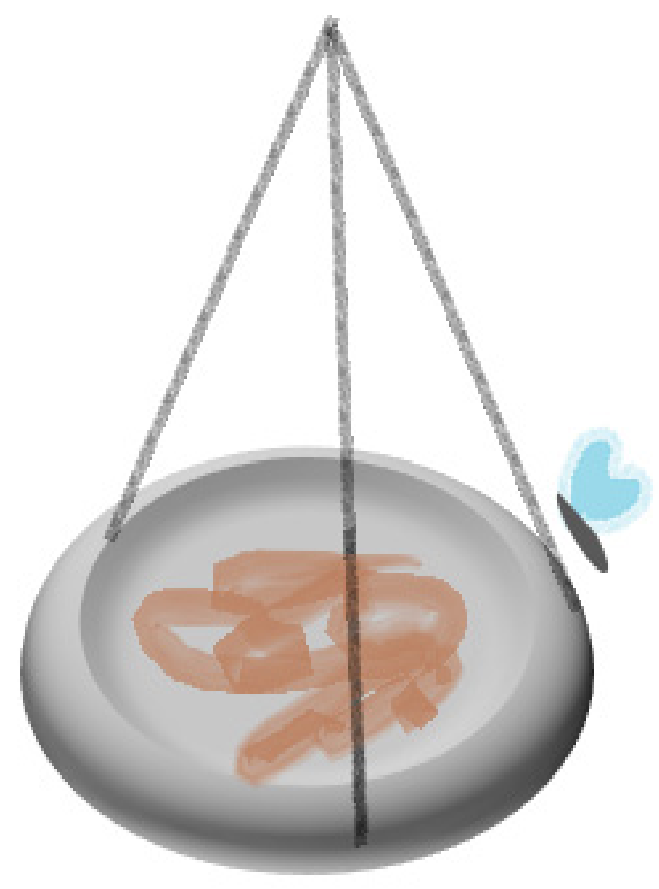

Figure A.9. Butterfly feeder. 


\section{Day 3: Underground \& Around}

\section{Overview}

The mysterious worlds under our forests are seldom explored. In the activities together for today, students will learn how exotic earthworms have changed our landscapes, and have the chance to sample different types of earthworms and learn about their biology. Students will then get acquainted with fungal ecology. A hike to collect samples and pictures of fungi in the Tech Trails or other trail system will be used to put together a walking tour pamphlet for hikers to find and identify local fungi on their own.

\section{General Activity Schedule}

1. Rhizotron tour

2. Earthworm Assemblies

3. Fungi Count and Collection

4. $\quad$ Fungi of Tech Trails Pamphlet

5. Future Fungal Fun (All about Spores)

\section{Activity \#1 - Rhizotron tour}

If doing activities in Houghton, MI, the Houghton Rhizotron at the USDA Forest Service Northern Forest Research Station is a great place to get a worm's eye view of the underground. Contact the local office to schedule a tour with a guide. The 75 foot tunnel underground is filled with windows into the earth to see roots, worm tunnels, centipedes, slugs, mites, fungi, and other organisms.

http://www.nrs.fs.fed.us/research/facilities/rhizotron/

\section{Activity \#2- Earthworm Assemblies}

Scout out an area in the Tech Trails, behind the MTU Forestry building. Many recreational areas, especially near towns, will have worms.

- Are earthworms good for our forests? (usually get a "yes" because they are good for garden soils) 
- $\quad$ But in a forest the answer is no! Worms decompose the leaf litter too rapidly (protection from temperatures, predation, and drying out) and intermix nutrients in soil horizons that the plants are not used to. Also ground nesting birds, insects, small mammals, amphibians, spiders, all lose habitat on the ground.

- $\quad$ NO earthworms are native to the Great Lakes Region! The last ice age extirpated them all. Most worms here now are European species slowly invading and changing our forests.

There are 4 methods to sample earthworms: 1) Flip and strip, litter, bark, rocks, 2) Hand sample with a shovel or spade, 3 ) count middens and castings (piles of earthworm poop on top of soil) in 1 meter square, or 4) liquid extraction.

Liquid extraction is the most fun and exciting sample method for students. Have a small tub and tweezers on hand to collect earthworms as they emerge. Use an old milk jug and mix 1 gallon water (4 liters) with $\sim 1 / 3$ cup (40 grams) ground yellow mustard seed from the grocery store or food co-op. One jug is enough to do 1 square foot plot. Clear away leaf litter and outline your plot area. Slowly start to pour solution into soil allowing it to soak into the ground as much as possible. If worms are present, they will start coming up immediately unless inactive due to cold or hot temps, very dry conditions, or heavy clay soil. Wait to 2 minutes, pour more, and continue flushing plot and collecting worms all the way emerged until solution is gone. Deeper worms will take longer to emerge (5-10 minutes).

Count the worms you get after 10 minutes and determine relative abundance of each type or species if you have a key. Species identification guides are available online but you can also ID worms to their ecological group just by color and size. Weigh worms in paper or plastic bags to measure worm biomass in your plot. If this is done at more than one field site (one heavily invaded and one still with a deep, undisturbed forest floor), have a discussion about the impacts of earthworm invasion in our forests.

\section{Activity \#3- Fungi Count and Collection}

Select a few trails in Tech Trails or choose a nature preserve, conservancy, or other forested area with hiking trails. Carry paper bags, fungi or mushroom field guides, and at least one digital camera. Tell students they are going on a mushroom hunt and will be looking for multiple types of fungi for collecting and taking pictures of. Show them pictures of sac fungi, gilled fungi, puffballs, conks or bracket fungi, slime molds, coral and jelly fungi, and boletes in the field guides to give them an idea of what to look for. 


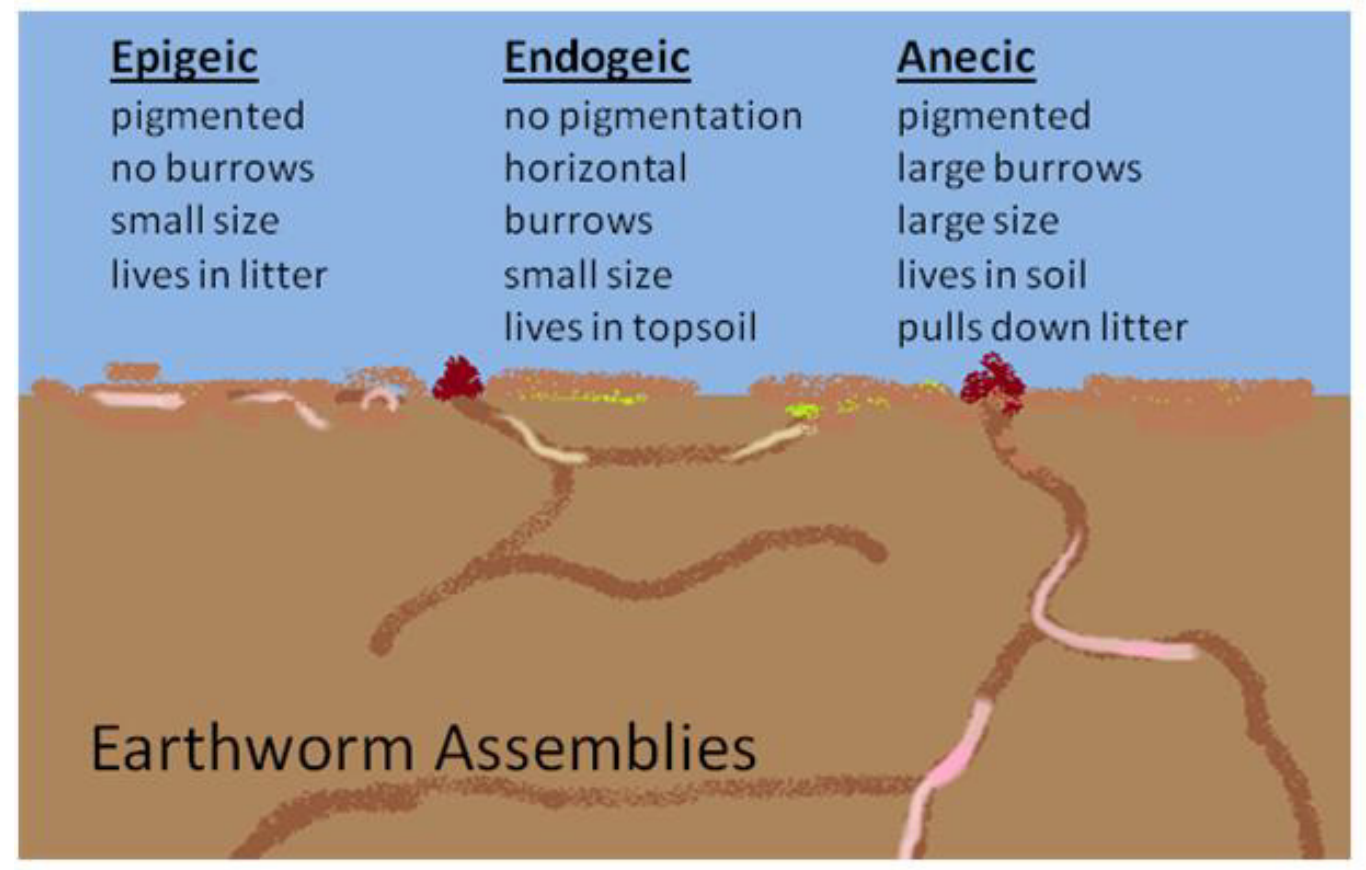

Figure A.10. The three categories of non-native earthworm assemblages.

\section{Activity \#4 - Create a Fungi Walking Tour Pamphlet}

Most trail systems have some sort of Tree Walking tour or labeled tree species for hikers to enjoy or learn about while in the woods. We will use our fungi collections and pictures to ID as many kinds of fungi as possible and create a walking tour and list of fungi for visitors to use on the trails we were on. A complete list of species found with some pictures from before and after picking would be very useful to people interested in finding mushrooms or learning more about the natural world. The trail manager may make the pamphlet available in print or online.

\section{Activity \#5 - Future Fungal Fun (All about spores)}

Traditionally mushrooms are divided into gill and non-gill fungi. Most students can equate fungal spores with seeds as a reproductive cell. Some gill fungi can only be identified by their spore color or spore print. Using white (colored mushrooms) or black paper (if it looks like a very white mushroom), gently place a gilled mushroom cap spore side down on the paper for one hour, before lifting straight off. Some mushrooms may need to be on paper for 24 hours before removing or very few spores will come off. An upside down glass will keep spores falling directly onto the paper. There should be a good outline of the gills or pores and you can see the spore color. Spray the paper gently with an aerosol hairspray or a clear acrylic to seal the spores to keep as art. 
Bracket fungi spores may be more of a harder concept as they usually appear drier than gilled fungi and spores are much less obvious. Using agar plates (light color gelatin works just as well for this) on a sterile surface hold a fresh bracket mushroom (not last year's dried conks) above the plate and gently tap on the fungi or use tweezers to scratch off some of the surface of the spore side of the mushroom. Examine the spores under a microscope and cover and store overnight or for a few days. By the next day, spores may have a tiny hyphae emerging just like a seed germinating. Allow students to reexamine plates periodically until program is done. Fungi and diseases should be kept local so don't send plates home with students if they are traveling. Also try growing bread mold or other mushroom spores, drawing what you see under the microscopes.

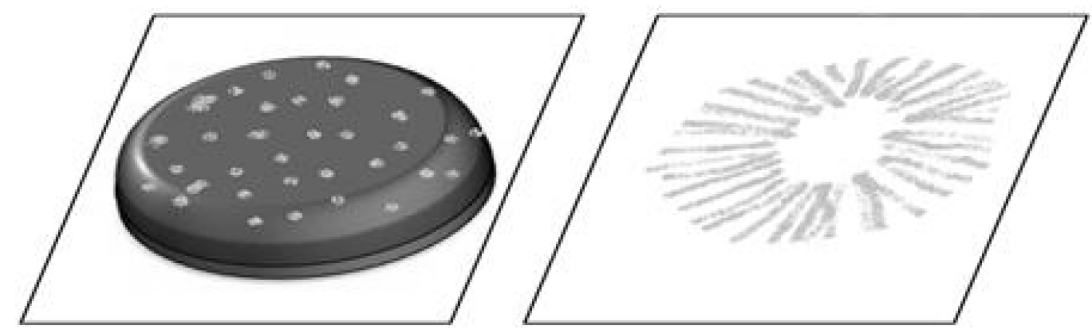

Figure. A.11. A mushroom cap on paper and the resulting spore print. 


\section{Day 4: Insect-ti-gators}

\section{Overview}

These activities are all geared toward encouraging students to closely examine insects and their impacts on plants and trees. If doing an insect collection for the week, be sure to remind students to collect insects they find throughout the day and freeze overnight. Students will find insect larvae inside plant parts and learn to tell different types of insect larvae apart. Insects also leave very specific evidence behind on trees that take a little bit of detective work to determine the culprits.

\section{General Activity Schedule \\ 1. Galling Galls \\ 2. Tree Detectives \\ 3. Caterpillar Capers \\ 4. Miniscule Miners}

\section{Activity \#1 - Galling Galls}

Those weird looking swelling or colored bumps on leaves are actually home to small creatures! A gall is an atypical growth by a plant in response to the irritation or some chemicals released by an organism (insects, fungi, mites, or viruses). In northern Michigan, easy galls to find include goldenrod ball galls, oak apple galls, spindle or bladder galls on maple leafs, pine cone ball galls on willow, and lots of other types. Galls provide food and shelter for many of their inhabitants. Galls can occur on practically any plant.

Scout an area for your morning hike ahead of time to find galls to point out to students. Go on a gall hunt and collect a variety of different types or sizes of galls. Try to find some from the previous year with an exit hole and some green galls from this year without any holes. If they are green galls, you can carefully use a small knife and cutting board to cut open the gall and look what's inside. Has any of the inside been eaten? Can you see an insect larva? If no one ever cut open galls or closely looked at insects in an insect collection, imagine how little we would know about the natural world! Other places to look for larvae are cocoons, under tree bark, and in spittlebug spit. 
Some students may wish to take galls home with them. Fresh galls can be placed in ventilated jars with damp soil on the bottom to see if adults eventually emerge. Old galls and other evidence of insects may also be good specimens for insect collections!
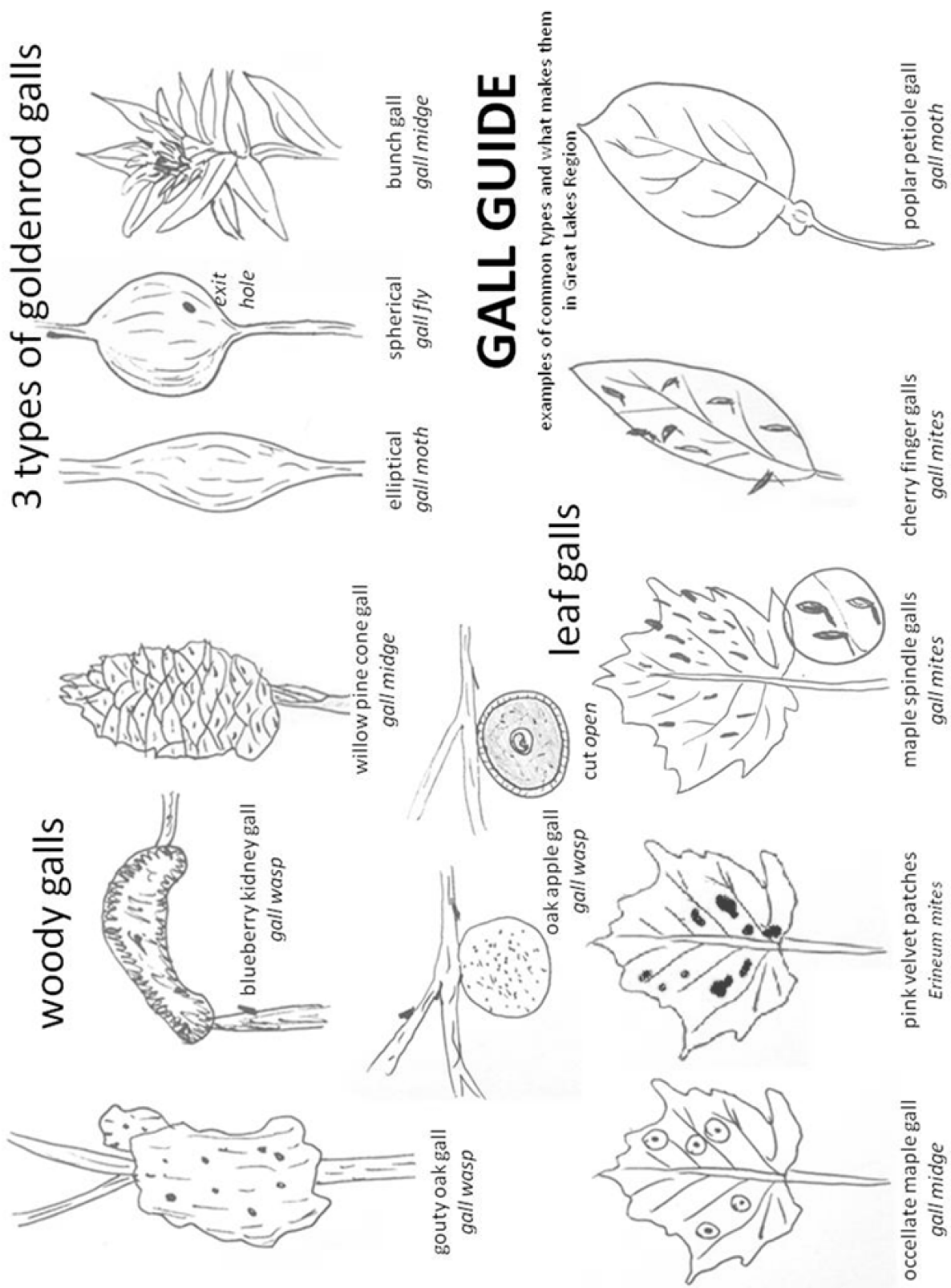

Figure A. 12. Gall Guide for common types found in the Great Lakes region. 


\section{Activity \#2 - Tree Detectives}

This activity is similar to the forest survey done in Day 2. It will work best if done in two separate places, one forested, more natural area, and one area near a campground or picnic area with a lot of recreation happening. This activity could also be done on school grounds or down an urban street. Explain what could cause each of the symptoms or signs on the Tree Trouble Guide (attached). For example, broken, dead branches or 'dieback' can be from lighting, poor nutrition, competition, or fungal attacks. Leaf deformities may be from insect activity, sun scalding, drought, or poor nutrition. Have students walk and check the number of trees they find in the box for each symptom (2 pages, one for each site).

- We're going to be "Tree-tectives" and look for healthy and unhealthy trees in the forest.

- What it is that makes trees sick? (by now they should come up with a good list: pollution, wounds, insects, diseases, fungi, or wounds and injuries).

- How would you prevent or combat these in a tree? (fertilizer, release from competition, insect control, protection from further man made damage)

- Compare the differences between the two sites afterwards and discuss what could have caused them. Were some damage symptoms more prevalent than others?

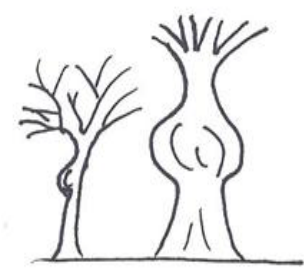

cankers swollen areas

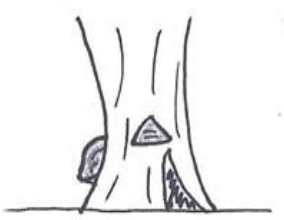

mushrooms decay

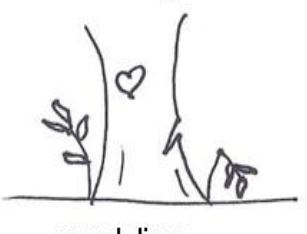

vandalism

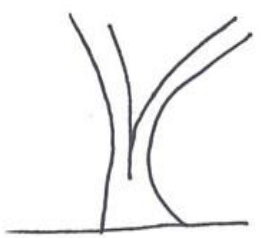

low forks creating weak areas

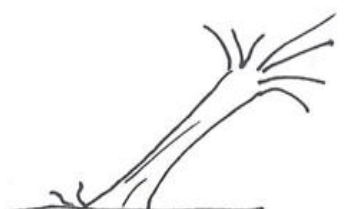

leaning trees exposed roots

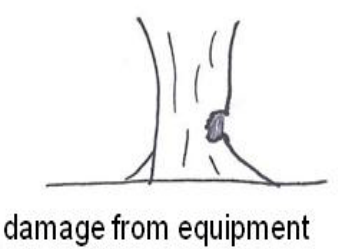

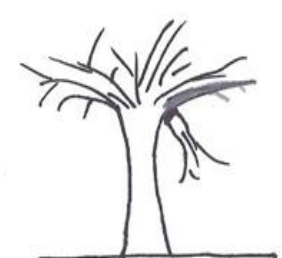

dead branches dead twigs

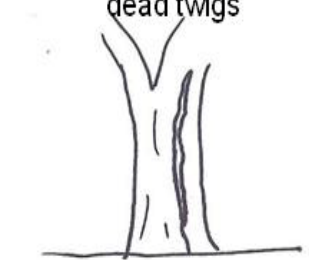

seams, cracks in bark

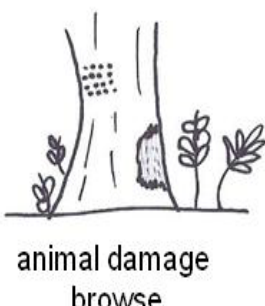

browse

Figure A.13. Forest Health Detective Guide. Don't forget to measure standing dead trees. 


\section{Activity \#3- Caterpillar Capers}

\section{Caterpillar Sampling}

Once again, a little bit of scouting before leading students out will make this activity go a lot smoother. Find a forested place with some defoliation or conifers with signs feeding (bent or wilted leaders, red or dying needles, or bagworms). A nearby stream will also provide a place to use a dip net and sample for more insect larvae. Also, if you have time to prepare a few days beforehand, a burlap sack tied around a tree trunk will provide shelter for many caterpillars that move down from the foliage. Inspect leaf edges with recent feeding, if browning has already occurred, you are likely too late and the specimen has moved on. Place a sheet under a tree or bush on a woodland edge (if you have time, wait an hour to see if frass (insect poop) falls onto the sheet) and gently shake or beat the foliage to make caterpillars drop onto the sheet. A tray with white paper works well too. You can also pass a net 10 times or so over and through vegetation to collect specimens. Be sure to give a WARNING about touching hairy or spiny caterpillars with bare hands as some people may be allergic or they may be poisonous.

Another fun aspect of insect larvae collection is to try to find one of each. Larvae may look like squiggly caterpillars or worms but have different numbers of legs or prologs and different names: caterpillar, larvae, grub, or maggot. Use the larval ID guide, "How to tell what a larvae will be" attached to examine their general body shape. To add specimens to collections, most soft-bodied caterpillars need to be preserved in alcohol but they can be freeze dried in a freezer for a few weeks.

If lots of caterpillars are found, it's time for Caterpillar Capers! Give each student a string the same length ( $3 \mathrm{ft}$ ). Each student gets a caterpillar to start at the end of the string and race to the top that they are holding: woolly bear caterpillars are so great at this they have their own annual Wooly Worm Race in North Carolina. Try out different species of caterpillars to see which one is the fastest.

\section{Caterpillar Experiment}

Resources:

1. Allen, J.A., Cooper, J.M., Hall, G.J., McHenry, C. 1993. “'Evolving pastry’: a method for simulating microevolution." Journal of Biological Education 27: 274-282.

2. Barber, N. 2012. "Clay caterpillars: a tool for ecology \& evolutionary laboratories." The American Biology Teacher 74: 513-517.

Make clay or pastry caterpillars to set out and test ecological and evolutionary principles. Roll out small caterpillars ( $3 \mathrm{~cm}$ long $\mathrm{x} 0.5 \mathrm{~cm}$ wide) and set out on lawn, boards, or pinned to tree branches. Use food coloring or clay to make caterpillars of different camouflage types, some with eyespots, or some with tails or horn shapes. Set 
up the night before or very early in the morning as most birds are active in the am hours. After 24 hours revisit and check which types of caterpillars and how many were 'eaten' (either having been pecked or are missing). Pastry caterpillars may incite birds to forage more for the reward: use $1 / 3$ cup lard, 1 cup flour, and $15 \mathrm{ml}$ water. Be sure to check if your institution has any limits on using animals even for a small classroom experiment like this.

This experiment is great in that it inspires critical thinking and has a limitless amount of questions students can devise ways to test and answer. Examples include questions relating to the distribution and abundance of birds and prey in various habitats, how natural selection shapes animals physical bodies or search behavior, or the spread of new mutations in 'successful' generations of caterpillars that are not 'eaten'

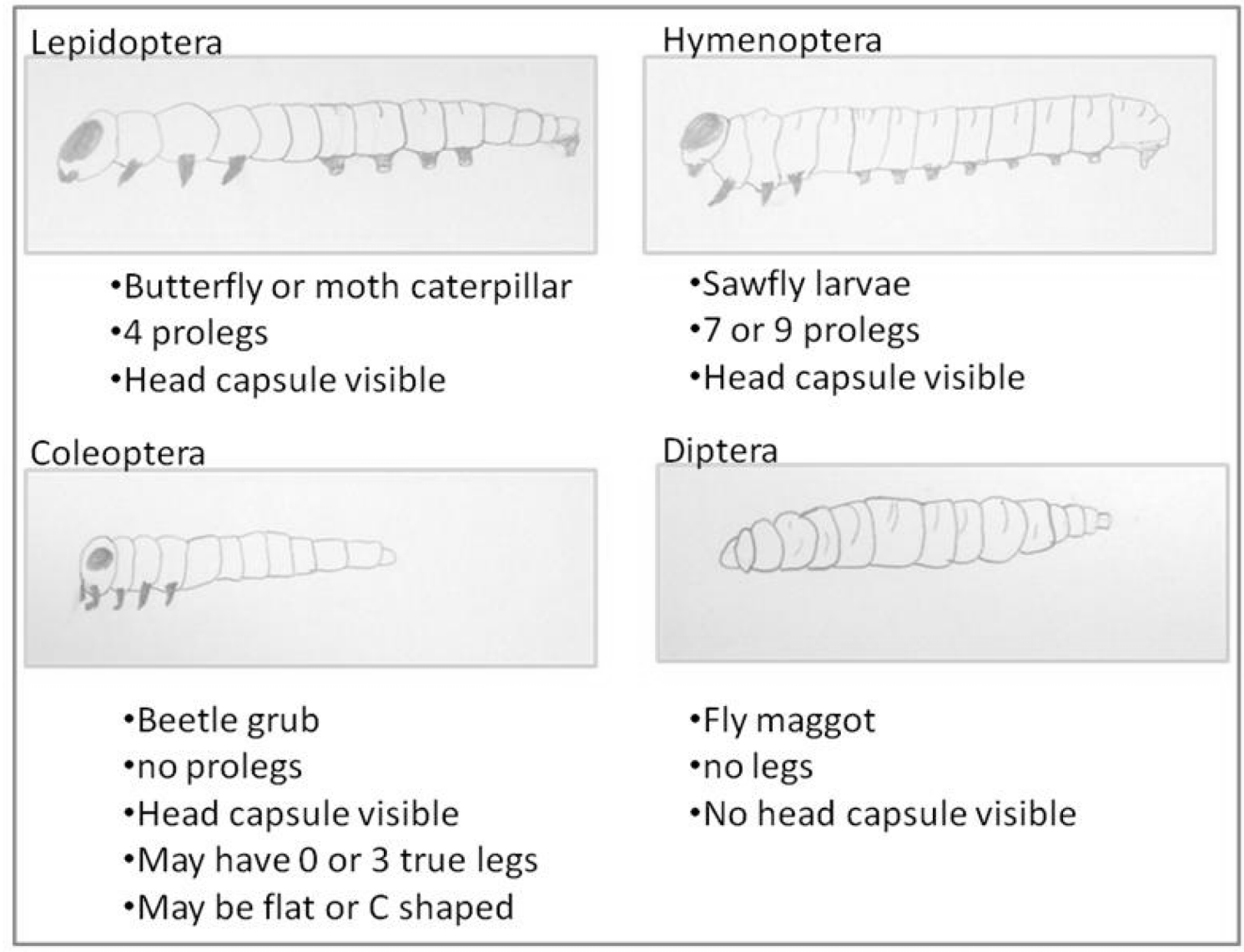

Figure A.14. Infographic explaining how to tell what a larva will be.

\section{Activity \# 4- Miniscule Miners}


Being in northern Michigan is a great place to tie the rich mineral mining history of the area to these insects. This activity can be combined with the galls, or spend part of the day visiting one of the area mines.

Some insect larvae live inside leaves for food and protection that don't form galls so we can see where they've lived their whole lives. Leaf-miners make squiggly lines or blotches that start where the adult laid an egg and the larvae traveled between cell layers in the leaf. Essentially, the leaves are a hotel, restaurant, and nursery one-stop-shop! Fruit trees and brambles are favorite species but maples, cherries, and poplar species also commonly have evidence of miners and blotchers. Mining insects typically include moth and fly larvae, with a few beetles and sawflies (wasps). Collect a variety of mined out leaves and tape them to the inside of a window. Look at the largest end of the mine to see if the larva is still inside or if you can see frass pellets. Try to find examples on different plant species of the main types of leaf mines (linear, trumpet, blotched, digitate, and tentiform (if they spin silk and fold the inside of the leaf).

\section{A leaf miner between cell layers}

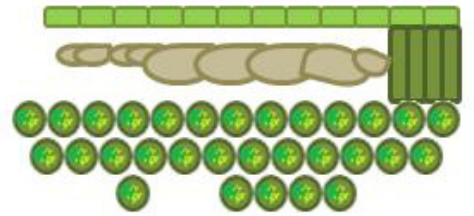

\section{Examples of Leaf Miner Shapes}

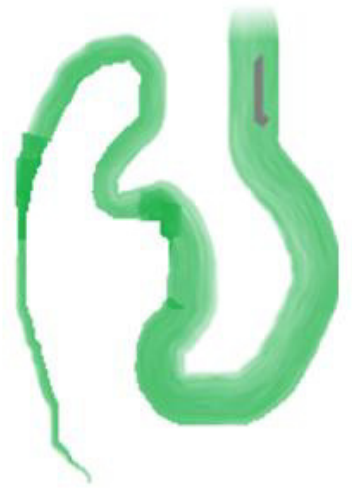

linear

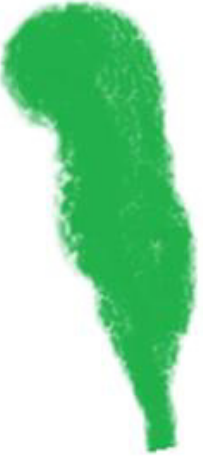

trumpet

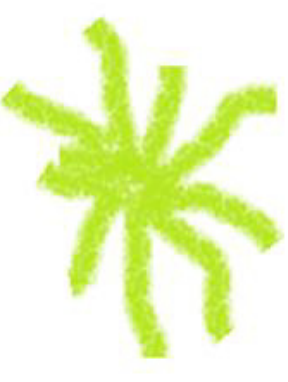

digitate

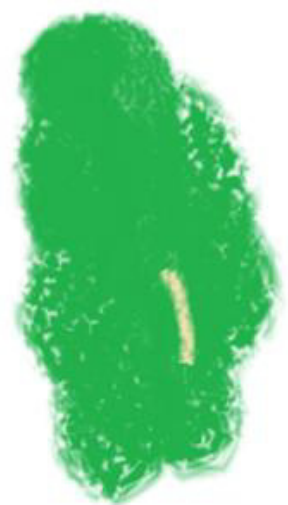

blotch

Figure A. 15. Diagram of leaf miner position and common shapes mined in foliage. 


\section{Day 5: Collection Day}

\section{Overview}

The last day of the program should be a wrap up day with students finishing up projects from the week. Collect any traps still out and be sure to have time to put together and ID all the rest of the insects and fungi found during the week. Students not excited to keep their findings will be glad to know that their collections will go to local science classrooms in the area. Make sure to have a discussion about favorite and least favorite activities for future programs. Tie it up with a talk about forest health and what they think it means to be healthy now that they've done the lessons.

\section{General Activity Schedule}

1. Pitfall Trap Collection and Sorting

2. Working Terrarium Jars

3. Put Together Insect and Fungi Collections

4. Pinning party with snacks and prizes for the week!

\section{Activity \#1 - Pitfall Trap Collection}

\section{Materials:}

For Pitfall Traps

- tweezers

- Styrofoam plates

- plastic baggies

- vials, ethanol for preserving

For Terrarium jars

- mason jars

- small spade

For Insect Collections

- pins

- shoe boxes, gift boxes with a lid

- $1 / 4$ " foam or styrofoam

- scissors

- paper

- glue

- insect ID books

- access to computers

- spreading board if needed

- hand lens

Vegetation can have a major impact on the orders and amounts of insects present. The food sources and microhabitats available to animals will determine whether they will be present or not. If a manager or entomologist is targeting a certain species, family, or order, (to either promote the population or suppress it) they could look at a trapping study to see what treatments or habitats favor the target species.

Return to the site of your pitfall traps. Carefully! Remove the lid and pull the trap out of the ground and pour the entire trap contents into a plastic baggy that zip seals. If using antifreeze as an attractant and insecticide, keep the liquid contained throughout sorting, place into a large jug, and dispose of at a nearby recycling center later. Have students sort through and count species, orders, or groups of insects to see who had placed their traps so they found the most diversity. Some insects may be preserved by rinsing and placing them in a vial with ethanol or alcohol for inclusion in student's insect collections. 


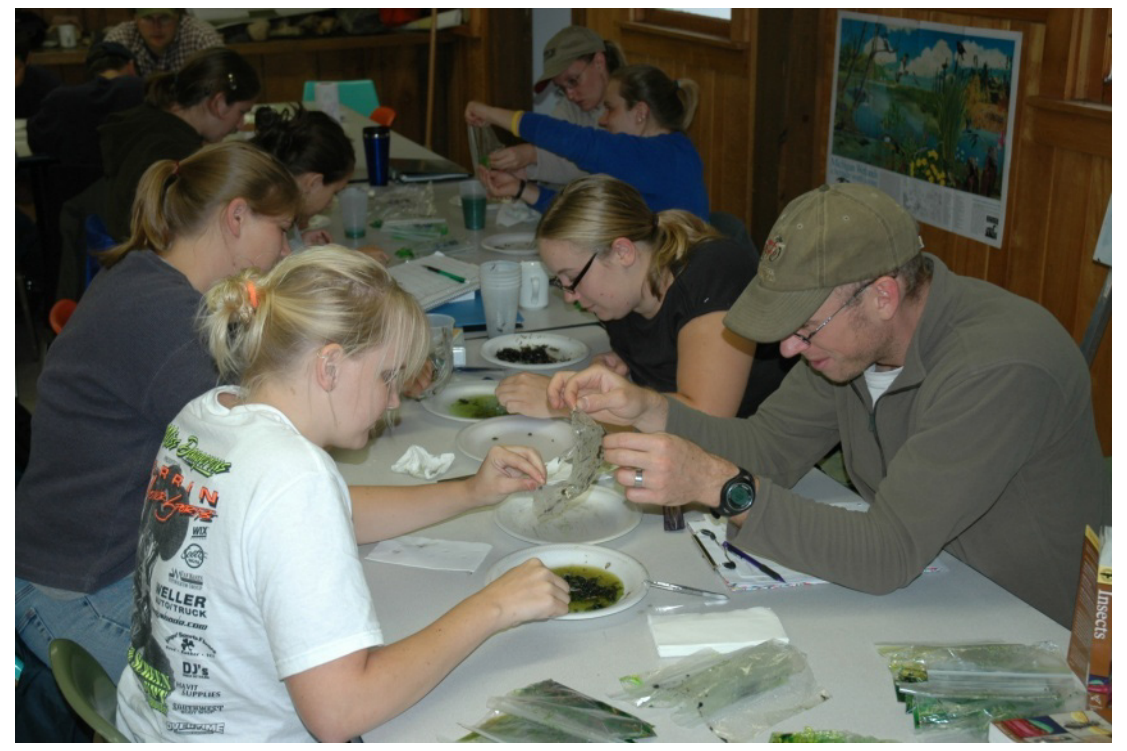

Figure A.16. Sorting pitfall trap catches. Photo by Andrew J. Storer.

\section{Activity \#2 - Working Terrarium Jars}

A neat way to view the forest floor and have a keepsake of the north woods is to make a working terrarium in a jar to view the underground and keep a few pet earthworms or pillbugs. Use widemouth mason jars or any glass jars. In a part of a forest trail (make sure it's OK to collect things and you're not in a nature preserve or protected area) we will essentially be placing part of the forest floor directly into a jar. Make sure to place a few pebbles or sandy soil in the bottom first since there will be no drainage in the bottom of the jar. Carefully set aside some leaf litter and use a small spade to gather and collect 2-3inches of topsoil and place in the jar. Place the leaf litter from on top of that spot into the jar. A few pieces of moss off of the ground or on a stick will add the green part to your forest floor terrarium. If one or two worms are added or any pillbugs, be sure to constantly add fresh leaf litter or kitchen compost for them to have food and shelter. Keep the jar moist but not soaking wet and out of direct sunlight. The organisms and plant life should keep for a long time!

\section{Activity \#3 - Insect Collections}

All week long, students have been collecting and freezing insects to pin into an insect collection either for themselves or to donate to local elementary schools that would love to use them for science classes! Start early in the afternoon so collections can be finished in a few hours before the end of the day. Gather lots of Insect ID books and instruct students in pinning before they get started. Insects taken out of the freezer should 
soften and be ready to pin right away. Insects are pinned through the thorax (middle part of body) but there are some exceptions. Insects too small to pin are glued to the tip of a small, triangle shaped piece of paper. Soft bodied (i.e. caterpillars) are preserved in vials of alcohol, not pinned. Butterflies, moths and some grasshoppers may need their wings spread out to dry in position before pinning. Use a spreading board or carefully spread apart wings and pin strips of paper over them onto the foam until they dry and are stiff. The beginning pages of most insect field guides have good directions for pinning insects. Also see the Michigan 4-H Entomology Manual for more detail.

A collection of pinned insects is a good teaching tool but to make it scientific and properly professional, insects should be labeled with their species, family, or order, who collected them, and where they were collected from. Write neatly and pin a small piece of paper next to, or under the insect on the same pin or type up your labels and print off with size 9 or smaller font, cut out and pin with insects. Insects should be preserved nicely in their boxes but moth balls may be needed if insects have dermestid beetles or mites eating them.

Students may also have paper bags or plastic bags of fungi that were collected. Place a note card with collector's name, collection location, type of fungus, and any other info such as host in the bag with the fungus. Students may keep collection for themselves or donate to a happy school.

\section{Supplemental Materials}

\section{More Ideas for Forest Health Activities and Integration in Classrooms}

1. Survey in healthy/polluted stream or harvested/forested one for different aquatic insects.

2. Gather mushrooms, conks, algae, or moldy food and examine different types of fungi by rolling a piece of tape over moldy bread or spores and looking at under a microscope.

3. Volunteer at a nature preserve or public trail system to pull invasive, exotic weeds.

4. Collect leaves with spindle galls, bladder galls, apple galls, tar spots, leaf miner galleries, leaf blotches, or rolled leaves or bagworm pouches. Research online or in field guides and try to find what organism is responsible.

5. Visit a university Entomology or Forestry Department and meet with a professional.

6. Visit a beekeeping farm and see how honey is gathered and made.

7. Buy a Japanese beetle trap from a garden/hardware store to watch insect pheromones in action.

8. Go on a hike and see who can find the largest/smallest mushrooms, the largest variety of colors, or the largest variety of texture (woody, slimy, shaggy, velvety, soft, hard, ect.) 
9. Design an insect that would live in trees/underground/in leaves/in attics! Then design a trap that would catch it!

10. Visit a farmer or gardener that uses biological control.

11. Look for fungal hyphae, galleries, and insect larvae in stacked firewood.

12. Put petroleum jelly on microscope slides in different locations or under fresh mushrooms to capture spores and air particulates and examine under a microscope.

13. Place a piece of firewood, or branch in a sealed cardboard box. Check the box periodically to see if any insects have emerged from the wood.

14. Collect caterpillar cocoons or order them online and raise butterflies and moths. Don't release them if you've collected gypsy moth (Lymantria dispar) cocoons.

15. Find a large ant mound. Set up a chair or blanket nearby and count how many ants come in and out in 15 minutes. If it's a very large mound, count how many pieces of food ants carry into the mound.

16. Build an antlion habitat. Place plenty of sand in a shallow cardboard box (shoebox) and carefully scoop up and introduce your new inhabitants. Once they get settled and scoop out a new pit, put in a few ants and watch the gory action.

17. Have a discussion about what you think is more important: big, large old trees or regenerating, young trees? Being able to use forests for wood, recreation or only natural areas? Letting native insect outbreaks naturally occur or salvaging wood afterwards? Ect.

18. Walk around your block or school and check street trees for damage and safety hazards.

19. Listen for and collect cicada nymph skin molts attached to trees (life cycles!)

20. During December, find out what mistletoe really is and what kinds are found near you.

21. In a small area of a forest, or woodlot, use GPS to mark snags (dead trees), cankers, or wounds on trees. Examine the map you made to see if there are any patterns.

22. Start gardening. Many garden insects and diseases have counterparts in natural areas.

23. Collect acorns or other tree seeds and plant in small clay pots. Replant outside after germination. Some seeds may need to be refrigerated or scarified (scratched on the surface) to come out of dormancy. Others will probably have feeding evidence on them!

24. Make measurements of your acorns or samaras before your plant them. Larger, heavier seeds should have more vigorous seedlings emerge.

25. Find artist's conks (Ganoderma applanatum), scratch a drawing into the bottom and dry.

26. Using bean seedlings to test how different levels of kitchen salt or acid rain (lemon juice) cause dieback or damage to the plants.

27. Wrap plastic wrap around a tree trunk at head level and cover with petroleum jelly. Check after a few days to see what landed on the tree. Try different species and open or forest locations.

28. Press skeletonized leaves to decorate with. Can also dip leaves carefully in wax or laminate to make interesting artwork. 
29. Closely examine a dead tree in the forest. How do you think it died? Does it have woodpecker holes or peeling bark animals might hide under? Insect holes or fungi?

30. Start a "Healthy Trees" Club at your school, to investigate and help keep trees healthy in your area or in your school yard, i.e. make signs about not peeling bark or leaves off.

31. Gather gross gunk! Hike around and see who can find the grossest natural thing, for example slime mold, seaweed, animal scat with fungi on it, or huge bugs.

32. Get 2 large glass jars and fill with soil, leaves, kitchen scraps, ect. Make sure only one of them has some earthworms and compare the difference every few days.

33. Diorama a healthy forest and an unhealthy forest in 2 different shoe boxes or as a classroom, make a large display with a healthy side and unhealthy side (one with lots of diversity and animals, some insects, some mushrooms, and some disease; the other side with much less diversity, lots of defoliation or insect holes and lots of dying or dead trees).

34. Look at stumps or cross cut 'cookies' of trees to see the annual rings. They can tell interesting stories about the health of a tree, including insect outbreak or drought years, competition, fire, and senescence.

35. Set up pitfall traps, sticky traps, or other type of insect traps during spring, summer, and fall to compare the effect of season on trap catch.

36. Gather tinder conks (Fomes or Phellinus) and test if they live up to their reputation.

37. Use a black light at night or use a large white bed sheet pinned to a laundry line with flashlights shining on it to attract moths and other night time fliers.

38. Look for lichens on wood, rock, and soil surfaces. Count how many different types you can find. Compare the number of lichens found in a city park and in a natural forest.

39. Create or research a recipe using edible mushrooms. In addition, try to use local, native mushrooms or ones from local mushroom farmers. Don't eat any wild mushrooms unless you are confident about your mushroom ID and don't forget about yeast also!

40. Before starting a hike, stamp children's hands with a mushroom, insect, or tree stamp to show that they are on the "team" of the organisms they will be looking for.

41. Put on a Bug Bowl or Insect Fair. Have students make posters of different types of important insects, display insect collections, wood with galleries, products made with the help of insects, insect face painting, bug bingo, ect. Serve chocolate covered bugs, popcorn flavored mealworms, or honey and toast. Invite other classrooms to your party.

42. The aliens have landed! Have each student pick an exotic invasive in your state to research and make a poster about it.

43. Look in art books or online to find classical art with containing insects, trees, or mushrooms before making your own. The North American Mycological Society has an online registry of mushrooms in works of art. Did the artists portray them biologically accurate or more stylized? 
44. Make up a "Treevia" Quiz game. Have everybody write down one Forest Health related quiz question and play for points like Jeopardy. They can be multiple choice, true or false, or short answer (e.g. "Maple sap is collected during the hot days of summer. True or False?" Or "Name the organism that reduces the litter layer in a forest, thus greatly warming and drying soils? A. earthworms B. earwigs C. salamanders")

45. Theme walks are easy to plan if you do some pre-scouting: organisms in dead trees, organisms living on logs, organisms on live trees, lichen and moss varieties, berry picking, ants and aphids, spider webs, animal homes, spittle bug hunt, edible or poisonous plants, etc.

\section{Selected Book Resources associated with Forest Health}

1. Project Learning Tree Environmental Activity Guide PreK-8, American Forest Foundation, Washington DC, 2001. (pgs may differ in newer/older versions)

- "Trees in Trouble" -tree damage, pgs 293-297

- "The peppermint beetle" - insect pheromones, pgs7-8

- We all need trees" - tree importance, pgs 39-42.

- "Trees as habitats" - organisms on trees, pgs 70-71

- "The fallen log" - fungi and decomposition, pgs 72-74

- "Pollution search" - ecosystems show signs of pollution, pgs 114-118

- "Are vacant lots vacant" - invasive species, pgs 153-155

- "How big is your tree" - tree measurements, pgs 239-243

- "Living with fire" - forest fire importance, pgs 311-315

2. Lingelbach, J. and L. Purcell. 2000. Hands On Nature: Information and Activities for exploring the environment with children. Vermont Institute of Natural Science. University Press of New England, New Hampshire

- "Amazing insects" - insect biology, pgs 12-18

- "The forest floor" - fungi biology, pgs 73-79

- "Rotting logs" - insect galleries, pgs 80-86

- "Insect lives" - insect life cycles, pgs122-128

- "Galls" - gall life cycles, pgs 152-156

3. Eiseman, C. and Charney, N. 2010. Tracks $\&$ sign of insects $\&$ other invertebrates: a guide to North American species. Stackpole Books, Mechanicsburg, PA. 582 pgs. 
4. Kellogg Markowsky, J. 1999. Shelterwood Teacher's Guide: Discovering the Forest. Tilbury House Publishers, Gardiner, Me. 92 pgs.

\section{Selected Online Resources for Forest Health information in the Great}

\section{Lakes Region}

1. Center for Exotic Species, 2009, Michigan Technological University, Weeds, Insects, Pathogens, http://ces.mtu.edu/

2. Michigan Department of Natural Resources. 2010-2011, Forests, Land, and Water: Forest Health. http://www.michigan.gov/dnr/0,1607,7-153-30301_30505_30830$--, 00 . h t m l$

3. Lurkers Going Berserk Activity Guide, 2006, Wisconsin Department of Natural Resources, Madison, WI, www.dnr.state.wi.us/org/land/forestry/Fh/

4. Great Lakes Worm Watch, 2011, University of Minnesota, http://greatlakeswormwatch.org/default.htm

5. Emerald Ash Borer Education Packet, USDA Forest Service Northeastern Area, State and Private Forestry, www.emeraldashborer.info (ret 8-5-2010)

6. Emerald Ash Borer, USDA Forest Service, Michigan State University, Purdue University and Ohio State University, http://emeraldashborer.info/

7. Ratkos, J.A., 4-H Club Entomology Leaders Guide, Michigan State University Extension, http://entnemdept.ufl.edu/bug_club/teacher-parents/pdf/4H14794HEntomologyLeadersGuide.pdf

8. Forestry images, weed images, insect images, IPM images, invasive images http://images.bugwood.org/

9. Penn State, School of Forest Resources, Forest Insect and Disease Pests, Lesson Plans 2011 http://sfr.psu.edu/youth/sftrc/lesson-plans/forestry/6-8/insectsdisease-pests 


\section{Appendix B}

This letter is for Chapter 5 (letter is one page).

71413

Michigan Techndogical Unversibl Mal - Re. Using an article in a Dissertaion

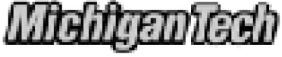

\section{Re: Using an article in a Dissertation}

ajps <ajps@scirp.org

Sat, May 25, 2013 at 12-05 PM

Reply-To: ajps cajpsigscip.org?

To: Tara Bal <tlbal(gintu.edus

Dear Dr. Tara Bal.

Thanks for your email!

If it is not for commercial use, you can included it then and please indicate the publication information in A.JPS.

Please feel free to contact me.

Joyce

AJPS Editorial Office

Email; ajpsiscirp,oró

http://www.scirp.ög/joumal/ajps/

From: Tara Bal

Date: 2013-05-25 01:22

To: American J. of Plant Sci.

Subject: Using an article in a Dissertation

Hello,

I am a currently finishing a doctoral dis:sertation and am looking to include a previously published joumal article as one of my chapters. The article published in A.JPS is "The relationship of the sapstreak fungus. Ceratocystis virescens, to sugar maple dieback and decay in Northern Michigan".

DOL: 10,4236 bjps 2013,42N056. I could not find instructions on the web on how to tobtain permission to use articles in a thesis or dissertation. I know the journal is Open Acces:s, but I do not know if this means Copyright permission is still needed to reuse an article lam first author on. Please let me know.

Thank you,

Tara Bal

Tara Bal

PhD Candidate

School of Forest Research and Environmental Science

Michigan Technological University

tlbaliamtu.edu, phone $906-281-6241$ 
This letter is for Chapter 6 (letter is two pages).

Jheins M chigan Technological Univers ty Mal - RE: Us ng Submitted art cle in a Disartation

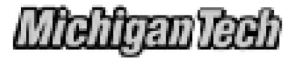

\title{
RE: Using Submitted article in a Dissertation
}

\author{
1 messag
}

Mark Penrose cmanagingeditor@nabt_org?

To: Tara Bal <tlbaliamtu_edus

Thu, vul 11, 2013 at 1:50 PM

Hi Tara,

Thanks for your message. I don't see any problem with including your submitted article as a chapter in your dissertation. You should know that after review you may need to revise your article (and chapter) but for now you can include it as a chapter.

Mark

Mark Penrose

Managing Editor

The American Biology Teacher

E-mail: managingeditor@abt.org

Fax: $479-935-4206$

From: Tara Bal [mailto:tbalimitu,edu]

Sent: Thursday, July 11, 2013 12:40 PM

To: managingeditor@nabtiorg

Subject: Using Submitted article in a Dissertation

Hello Mark,

I am a currently finishing a doctoral dissertation and am locking to include a submitted article as a chapter. The article submitted to The American Biology Teacher is "Forest Health Detectives", Log No, ABT-1022-Jun2013 with myself as the conly author. I did not see instructions on the web page on oblaining permission lor us ing previously submitied articles, Is there an Open Aocess Policy? Al submitted and previously published articles are referenced and pretaced, but I wanted to double check with you about the joumal's policy.

\section{2 of 3 pages}


Whats

Thank you,

Tara L. Bal

Tara Bal

\section{PhD Candidate}

Assistant to the Director of Development and Outreach

School of Forest Research and Envirommental Science

Michigan Technological University

tlbal $\not$ intu.edu, 906-487-1898, 906-281-6241

Dear Tara Bal,

Thank you for submitting your manuscript: "Forest Health Detectives" to the The AmericanBiology Teacher, It has been identified as Log Nó. ABT-1022-Jun-2013 for tracking purposes during the review process. The editor responsible for your manuscript is William Leonard and can be reached by e-mail at leonard@clemson.edu.

Once our readers have reviewed your essay, the editor will send you the readers' reports along with the decision whether to publish or not. Often our acceptance of an essay is contingent upon revision, and we ask potential contributors to revise and resubmit the essay along the lines suggested by the editor and reviewers.

If you have any questions, you may reach me via e-mail al managingeditoranablorg.

Sincerely yours.

Mark. M. Penrose

Managing Editor

The American Biology Teacher

3 of 3 pages 